\title{
Environmental Monitoring Report for Commercial Low-Level Radioactive Waste Disposal Sites (1960's through 1990's)
}

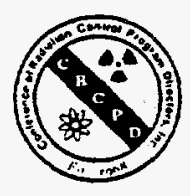

Conference of Radiation Control Program Directors, Inc.

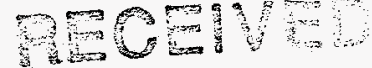

JUN 09 โุด7

OSTI

November 1996

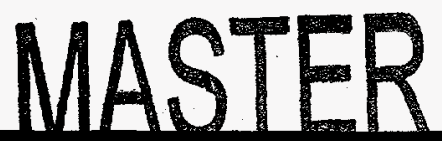




\section{DISCLAIMERS}

The information contained in this document is for guidance. The implementation and use of the information and recommendations contained in this document are at the discretion of the user. The implications from the use of this document are solely the responsibility of the user.

This document has been developed by a working group of the Conference of Radiation Control Program Directors, Inc. (CRCPD) and endorsed by the Board of Directors. The contents contained herein, however, may not necessarily represent the views of the entire membership of the CRCPD or any federal agency supporting the work contained in this document. The mention of commercial products, their sources, or their use in connection with material reported herein is not to be construed as either an actual or implied endorsement of such products by the CRCPD or any federal agency.

This publication was supported in part by grant number NRC-04-88-149 from the U.S. Nuclear Regulatory Commission.

Neither the United States Government nor any agency thereof, nor any of their employees, makes any warranty, express or implied, or assumes any legal liability or responsibility for the accuracy, completeness, or usefulness of any information, apparatus, product or process disclosed, or represents that its use would not infringe on privately owned rights. References herein to any specific commercial product, process, or service by trade name, trademark, manufacturer, or otherwise, does not necessarily constitute or imply its endorsement, recommendation, or favoring by the United States Government or any agency thereof. The views and opinions of authors expressed herein do not necessarily state or reflect those of the United States Government or any agency thereof. 


\section{Environmental Monitoring Report for Commercial Low-Level Radioactive Waste Disposal Sites (1960's through early 1990's)}

November 1996

Report prepared by

CRCPD Committee on Radioactive Waste Management and endorsed by CRCPD Board of Directors

This document did not undergo the CRCPD editorial process

Published by

National Low-Level Waste Management Program

Prepared for

U.S. Nuclear Regulatory Commission under Grant No. NRC-04-88-149

and

U.S. Department of Energy

Office of Environmental Restoration and Waste Management Under DOE Idaho Operations Office

Contract DE-AC07-94ID13223 


\section{DISCLAMMER}

Portions of this docament may be illegible in electronic image products. Images are produced from the best available original document. 



\section{ABSTRACT}

During the time period covered in this report (1960's through early 1990's), six commercial low-level radioactive waste (LLRW) disposal facilities have been operated in the United States. This report provides environmental monitoring data collected at each site. The report summarizes: (1) each site's general design, (2) each site's inventory, (3) the environmental monitoring program for each site and the data obtained as the program has evolved, and (4) what the program has indicated about releases to off-site areas, if any, including a statement of the actual health and safety significance of any release. A summary with conclusions is provided at the end of each site's chapter.

The six commercial LLRW disposal sites discussed are located near:

- Sheffield, Illinois

- $\quad$ Maxey Flats, Kentucky

- Beatty, Nevada

- West Valley, New York

- Barnwell, South Carolina

- Richland, Washington 


\section{ENVIRONMENTAL MONITORING REPORT FOR COMMERCIAL LLRW DISPOSAL SITES TABLE OF CONTENTS}

ABSTRACT $\ldots \ldots \ldots \ldots \ldots \ldots \ldots \ldots \ldots \ldots \ldots \ldots \ldots \ldots \ldots \ldots \ldots \ldots \ldots$

ACRONYMS, INITIALISMS, AND ABBREVIATIONS $\ldots \ldots \ldots \ldots \ldots \ldots$ xiii

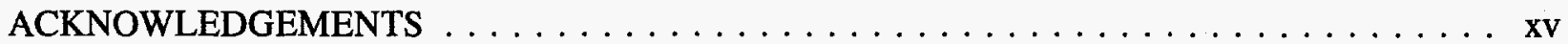

CHAPTER 1-Environmental Monitoring Report for Commercial Low-Level Radioactive Waste Disposal Sites

ENVIRONMENTAL MONITORING PERSPECTIVES

CHAPTER 2-Environmental Summary of the Sheffield, Illinois Low-Level

Radioactive Waste Disposal Site

INTRODUCTION

SITE

ENVIRONMENTAL MONITORING

SUMMARY

REFERENCES

CHAPTER 3-Environmental Summary of the Maxey Flats, Kentucky Low-Level Radioactive Waste Disposal Site

INTRODUCTION

SITE

ENVIRONMENTAL MONITORING

SUMMARY

REFERENCES

CHAPTER 4-Environmental Summary of the Beatty, Nevada Low-Level Radioactive Waste Disposal Site

INTRODUCTION

SITE 
SUMMARY

CHAPTER 5-Environmental Summary of the West Valley, New York Low-Level Radioactive Waste Disposal Site

INTRODUCTION $\ldots \ldots \ldots \ldots \ldots \ldots \ldots \ldots \ldots \ldots \ldots \ldots \ldots \ldots \ldots \ldots \ldots \ldots \ldots$

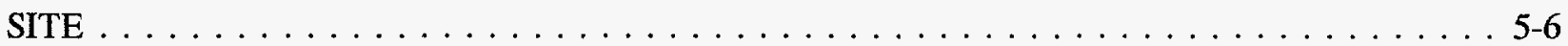

ENVIRONMENTAL MONITORING $\ldots \ldots \ldots \ldots \ldots \ldots \ldots \ldots \ldots \ldots \ldots \ldots \ldots$

SUMMARY . . . . . . . . . . . . . . . . . . . . . . $5-23$

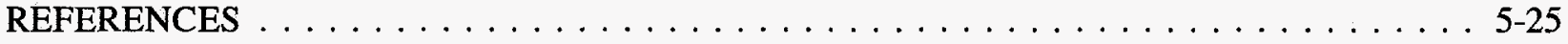

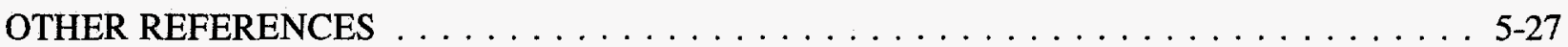

CHAPTER 6-Environmental Summary of the Barnwell, South Carolina Low-Level Radioactive Waste Disposal Site

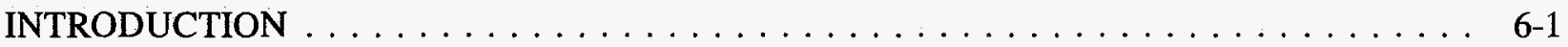

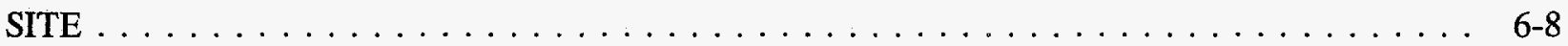

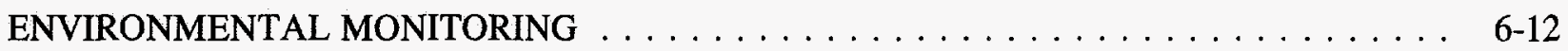

SUMMARY . . . . . . . . . . . . . . . . . . . . . . . . $6-19$

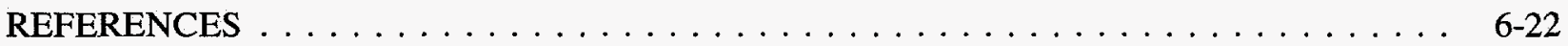

CHAPTER 7-Environmental Summary of the Richland, Washington Low-Level Radioactive Waste Disposal Site

INTRODUCTION $\ldots \ldots \ldots \ldots \ldots \ldots \ldots \ldots \ldots \ldots \ldots \ldots \ldots \ldots \ldots \ldots \ldots$

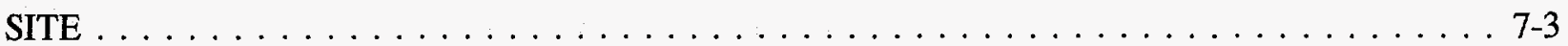

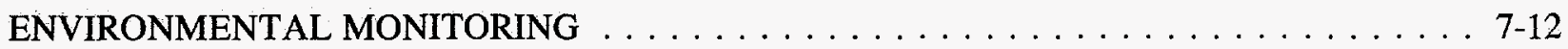

NON-RADIOLOGICAL ENVIRONMENTAL PROGRAM $\ldots \ldots \ldots \ldots \ldots \ldots \ldots \ldots$

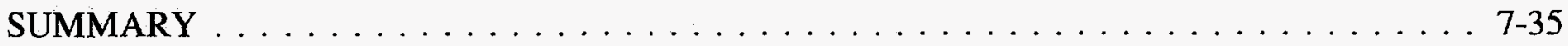




\section{FIGURES}

1-1. Location of the six commercial LLW disposal facilities discussed

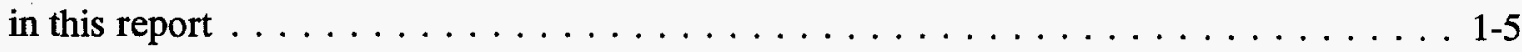

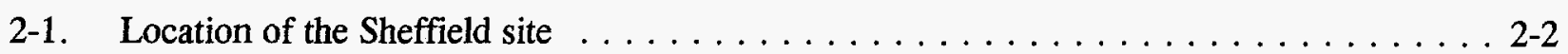

2-2. Plan view of Sheffield low-level radioactive waste and chemical disposal areas . . . . . 2-3

2-3. Location of geologic cross section for the Sheffield site $\ldots \ldots \ldots \ldots \ldots \ldots$

2-4. Geologic cross section for the Sheffield site $\ldots \ldots \ldots \ldots \ldots \ldots$. . . . . . . . .

2-5. Stratigraphy of northern Illinois and the Sheffield site $\ldots \ldots \ldots \ldots \ldots$

2-6. Map of well locations, trenches and tunnels at the Sheffield site . . . . . . . . . . . 2-9

2-7. Ground water flow boundaries, direction of flow and principal flow paths for the Sheffield site . . . . . . . . . . . . . . . . . . . . . . 2-10

2-8. Trout Lake sampling locations at the Sheffield site $\ldots \ldots \ldots \ldots \ldots \ldots \ldots$

2-9. Well locations and tritium concentrations in water at the Sheffield site $\ldots \ldots \ldots 2-18$

2-10. Tritium concentrations in northeast pathway wells at the Sheffield site $\ldots \ldots \ldots$. . . 20

2-11. Tritium concentrations in Trout Lake near the Sheffield site $\ldots \ldots \ldots \ldots . \ldots .21$

2-12. Environmental sampling around the Sheffield site $\ldots \ldots \ldots \ldots \ldots \ldots$

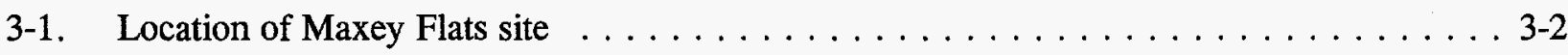

3-2. General map of the restricted area at the Maxey Flats site $\ldots \ldots \ldots \ldots \ldots$

3-3. Trench locations as of 1987 at the Maxey Flats site $\ldots \ldots \ldots \ldots \ldots \ldots$

3-4. Downslope location of forested areas relation to the Maxey Flats site . . . . . . . . 3-10

3-5. Well locations and tritium concentrations $(\mathrm{pCi} / \mathrm{mL})$ at the Maxey Flats site . . . . . . 3-14

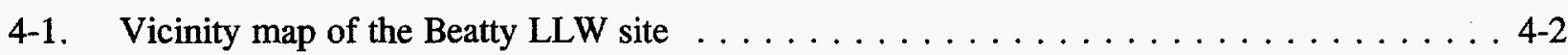

4-2. Facility map of trench locations at the Beatty $L L W$ site $\ldots \ldots \ldots \ldots \ldots$ 
4-3. Airborne activity monitoring stations of the Beatty LLW site $\ldots \ldots \ldots \ldots \ldots$

4-4. Monitoring wells of the Beatty LLW site $\ldots \ldots \ldots \ldots \ldots \ldots \ldots$

4-5. Site geology of the Beatty LLW site $\ldots \ldots \ldots \ldots \ldots \ldots \ldots \ldots$

4-6. Gross alpha ground water samples: Beatty, Nevada . . . . . . . . . . . . . 4-14

4-7. Gross beta ground water samples: Beatty, Nevada . . . . . . . . . . . . . 4-15

4-8. Tritium ground water samples: Beatty, Nevada . . . . . . . . . . . . 4-16

4-9. Gross alpha soil samples: Beatty, Nevada . . . . . . . . . . . . . . . 4-22

4-10. Gross beta soil samples: Beatty, Nevada $\ldots \ldots \ldots \ldots \ldots \ldots \ldots \ldots$. . . . . . . . . .

4-11. Gross alpha vegetation samples: Beatty, Nevada . . . . . . . . . . . . 4-26

4-12. Gross beta vegetation samples: Beatty, Nevada . . . . . . . . . . . . . . . 4-27

4-13. Ambient gamma: Beatty, Nevada . . . . . . . . . . . . . . . . . . . 4-29

5-1. Principal facilities at the West Valley LLW site $\ldots \ldots \ldots \ldots \ldots \ldots$

5-2. State-licensed trenches at the West Valley LLW site $\ldots \ldots \ldots \ldots \ldots \ldots \ldots$

5-3. Geological cross-section at the West Valley LLW site . . . . . . . . . . . . 5-10

5-4. Strontium-90 on Cattaraugus Creek at Springville Dam . . . . . . . . . . . 5-12

5-5. Tritium on Cattaraugus Creek at Springville Dam . . . . . . . . . . . 5-13

5-6. On-site surface water sampling locations at the West Valley
LLW site $\ldots \ldots \ldots \ldots \ldots \ldots \ldots \ldots \ldots \ldots \ldots \ldots \ldots \ldots \ldots \ldots \ldots \ldots \ldots \ldots \ldots$

5-7. West Valley demonstration project sampling site $\ldots \ldots \ldots \ldots \ldots \ldots \ldots$. $\ldots \ldots$

5-8. West Valley demonstration project on-site sampling $\ldots \ldots \ldots \ldots \ldots \ldots \ldots$

5-9. West Valley on-site ground water monitoring network $\ldots \ldots \ldots \ldots \ldots \ldots \ldots$. . . . .

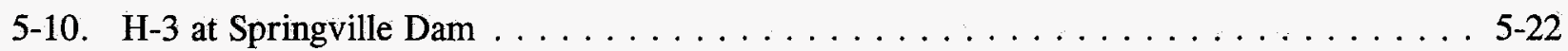

5-11. Sr-90 at Springville Dam . . . . . . . . . . . . . . . . $5-23$

6-1. Location of Barnwell site $\ldots \ldots \ldots \ldots \ldots \ldots \ldots \ldots \ldots \ldots \ldots \ldots \ldots$ 
6-2. Plan view of the Barnwell site showing adjacent land owners

6-3. Typical disposal trench at the Barnwell site $\ldots \ldots \ldots \ldots \ldots \ldots \ldots \ldots$

6-4. Barnwell site enhanced cap cross section $\ldots \ldots \ldots \ldots \ldots \ldots \ldots \ldots$

6-5. Stratigraphic and lithographic interpretation of the Barnwell site $\ldots \ldots \ldots \ldots$. $\ldots \ldots$

6-6. Plan view of the Barnwell site showing adjacent land owners/boundary sampling

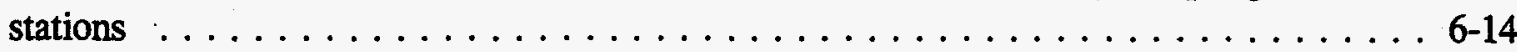

6-7. Approximate tritium plume outline south of the Barnwell site $\ldots \ldots \ldots \ldots$. $\ldots \ldots$

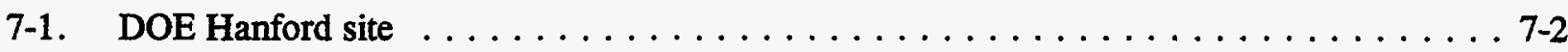

7-2. Low-level radioactive waste management facility, US Ecology; Inc., Richland, Washington . . . . . . . . . . . . . . . . . . . . 7-4

7-3. Environmental radiation sampling stations at the US Ecology site $\ldots \ldots \ldots \ldots$

7-4. Environmental radiation sampling stations in the vicinity of the Hanford site $\ldots \ldots \ldots$

7-5. Geological cross-section of the Hanford site $\ldots \ldots \ldots \ldots \ldots \ldots \ldots \ldots \ldots$

7-6. Off-site ground water sampling stations near the Hanford site $\ldots \ldots \ldots \ldots \ldots$

7-7. Ambient gamma $(\mathrm{mrem} / \mathrm{yr}) \ldots \ldots \ldots \ldots \ldots \ldots \ldots \ldots \ldots \ldots \ldots$

\section{TABLES}

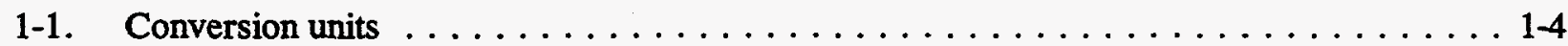

2-1. Estimated key radionuclides (half-lives greater than five years) at the Sheffield site . . . . . . . . . . . . . . . . . . . . . . . . 2-4

2-2. Examples of biota found near the Sheffield site $\ldots \ldots \ldots \ldots \ldots \ldots \ldots$

2-3. Tritium concentrations in Trout Lake in $\mathrm{nCi} / \mathrm{L} 1981-1994$ at the Sheffield site . . . . . 2-17

2-4. Tritium concentrations in streams and creeks in $\mathrm{nCi} / \mathrm{L}$ 1981-1994 at the Sheffield site

2-5. Air sampling results in $\mathrm{fCi} / \mathrm{m}^{3} 1977-1994$ at the Sheffield site $\ldots \ldots \ldots \ldots$. . . . . 2-26

2-6. Direct radiation (TLD) results in $\mathrm{mR} / \mathrm{y} 1977-1994$ at the Sheffield site . . . . . . . 2-27 
3-1. Stratigraphy of the Maxey Flats site

3-2. Selected ground water well sampling data for tritium $(\mathrm{pCi} / \mathrm{L})$ at the



3-3. Kentucky maximum permissible concentrations of radioactivity in air and water . . . . 3-13

4-1. History of radioactive waste disposal volume and activity at the Beatty

4-2. Action levels for gross alpha and gross beta in soil, vegetation, and ground water

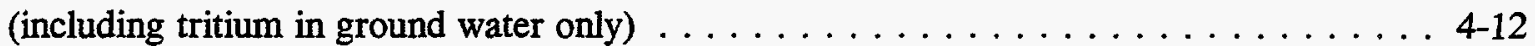

4-3. Gross alpha, gross beta, and tritium activity in ground water $\ldots \ldots \ldots \ldots$

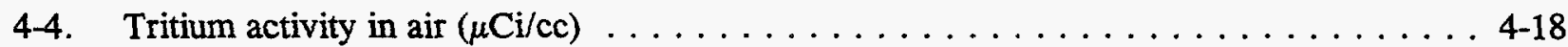

4-5. Soil sample analysis-Beatty $\mathrm{LLW}$ Site . . . . . . . . . . . . . . . . . . . . . 4-20

4-6. Gamma spectroscopy analysis of soil samples (pCi/gm) (April 1982) . . . . . . . . 4-21

4-7. Vegetation sample analysis-Beatty LLW Site $\ldots \ldots \ldots \ldots \ldots \ldots \ldots \ldots \ldots$

4-8. Tritium and gamma spectroscopy analysis of vegetation samples (March 1982) . . . . . 4-28

4-9. Direct radiation $\ldots \ldots \ldots \ldots \ldots \ldots \ldots \ldots \ldots \ldots \ldots \ldots$

5-1. Sources of waste in the state-licensed disposal area through $1972 \ldots \ldots \ldots \ldots$

5-2. West Valley trench inventory $\ldots \ldots \ldots \ldots \ldots \ldots \ldots \ldots \ldots \ldots \ldots \ldots \ldots$

5-3. West Valley demonstration project sites $\ldots \ldots \ldots \ldots \ldots \ldots \ldots \ldots \ldots$

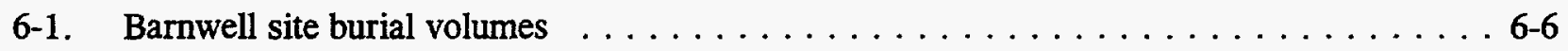

6-2. Rainfall for Barnwell County . . . . . . . . . . . . . . . . . . . . . . 6-9

6-3. Biota found in Barnwell County $\ldots \ldots \ldots \ldots \ldots \ldots \ldots \ldots \ldots \ldots \ldots$

6-4. 1992 tritium monitoring data for ground waters and streams near the Barnwell site . . . . . . . . . . . . . . . . . . . . . . 6-15

6-5. 1992 monitoring data for air near the Barnwell site . . . . . . . . . . . . . 6 6-16

6-6. 1992 precipitation monitoring data for the Barnwell site $\ldots \ldots \ldots \ldots \ldots \ldots$. . . . . . . 
6-7. 1992 direct radiation levels of South Carolina locations $\ldots \ldots \ldots \ldots \ldots \ldots$. . . . . . .

6-8. 1992 monitoring data for soil near the Barnwell site $\ldots \ldots \ldots \ldots \ldots \ldots \ldots \ldots$

6-9. 1992 monitoring data for sediment near the Barnwell site . . . . . . . . . . . . 6-18

6-10. 1992 monitoring data for vegetation near the Barnwell site $\ldots \ldots \ldots \ldots \ldots \ldots$. . . . . 6-19

7-1. Monthly climatological data from the Hanford Meteorological Station, $1991 \ldots$. . . . 7-8

7-2. Common species of mammals, birds, and vegetation $\ldots \ldots \ldots \ldots \ldots \ldots \ldots$

7-3. Environmental/occupational monitoring requirements $\ldots \ldots \ldots \ldots \ldots \ldots \ldots$

7-4. Action required when action level met or exceeded $\ldots \ldots \ldots \ldots \ldots \ldots \ldots$

7-5. Required minimum detectable concentrations (MDCs) for gamma spectroscopy

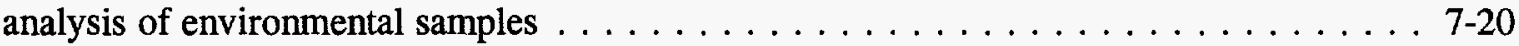



7-7. Analysis results (alpha, beta, and tritium) for ground water wells $\ldots \ldots \ldots \ldots$. . . . . $\ldots$ 22

7-8. Maximum tritium concentration in ground water (on-site) wells $(\mathrm{pCi} / \mathrm{L}) \ldots \ldots$. . . . . $7-23$

7-9. Maximum tritium concentrations in U.S. DOE ground water wells located in the

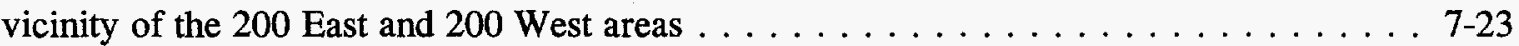

7-10. Analytical results for isotopic uranium $\ldots \ldots \ldots \ldots \ldots \ldots \ldots \ldots \ldots \ldots \ldots$

7-11. Gross beta and gross alpha measurements of particulate air samples from

7-12. Maximum $\mathrm{I}-125$ concentration in the air $\ldots \ldots \ldots \ldots \ldots \ldots \ldots \ldots \ldots \ldots$

7-13. Tritium air moisture concentrations at environmental monitoring stations 1,2 , and $5\left(10^{-12} \mu \mathrm{Ci} / \mathrm{mL}\right)$

7-14. Soil analysis (pCi/gm)

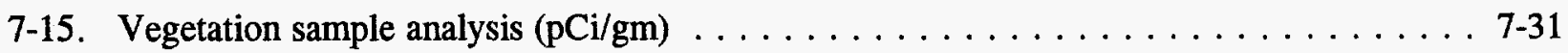

7-16. Ambient gamma (penetrating radiation) $(\mathrm{mrem} / \mathrm{yr}) \ldots \ldots \ldots \ldots \ldots \ldots \ldots$

7-17. Chemical analysis of on-site well samples-1992 $\ldots \ldots \ldots \ldots \ldots \ldots$ 


\section{ACRONYMS, INITIALISMS, AND ABBREVIATIONS}

AEC U.S. Atomic Energy Commission

ALARA as low as reasonably achievable

ARMS Aerial Radiological Measuring Surveys

ASDA New York State Atomic and Space Development Authority

BLM Bureau of Land Management

$\mathrm{Bq} \quad$ Becquerel

CFR Code of Federal Regulations

$\mathrm{Ci} \quad$ curie

CNSI Chem-Nuclear Systems, Inc.

CRCPD Conference of Radiation Control Program Directors

DEC Department of Environmental Conservation

DHEC Department of Health and Environmental Control

DOE U.S. Department of Energy

DOH Department of Health

EIS Environmental Impact Statement

EPA U.S. Environmental Protection Agency

FAR Facility Assessment Report

HDPE high density polyethylene

HIC high integrity container

HMS Hanford Meteorological Station

HTO tritiated water

HWMF hazardous waste management facility

KAR Kentucky Administrative Regulations

LLDs lower limits of detection

LLW low-level radioactive waste

LLRW low-level radioactive waste

LSA low specific activity

MDC minimum detectable concentration

NDA NRC-licensed disposal area

NECO Nuclear Engineering Company

NFS Nuclear Fuel Services, Inc.

NRC U.S. Nuclear Regulatory Commission

NYCR New York Code of Regulations

NYSERDA New York State Energy Research and Development Authority

NYSGS New York State Geological Survey 
PCBs polychlorinated biphenyls

PL public law

$\mathrm{ppb} \quad$ parts per billion

PVC polyvinyl chloride

QA quality assurance

QC quality control

RCRA Resource Conservation and Recovery Act

SARA Superfund Amendments and Reauthorization Act

SDA State-licensed disposal area

TDS total dissolved solids

TLDs thermoluminescent dosimeters

TOC total organic carbon

USGS U.S. Geological Survey

WAC Washington State Administrative Code

WVDP West Valley Demonstration Project

WVNS West Valley Nuclear Services, Inc. 


\title{
ACKNOWLEDGEMENTS
}

This report was a cooperative effort over more than a decade. Each member of the CRCPD Committee on Radioactive Waste Management, led by committee chairs Bill Dornsife, Virgil Autry, Ken Weaver, and Paul Merges, contributed in some measure to drafting and editing this report.

Committee E-5 membership since 1985 has included:

\author{
Virgil Autry (SC) \\ Darice Bailey (CA) \\ Harold Borchert (NE) \\ Bill Dornsife (PA) \\ Stan Marshall (NV) \\ Kevin McCarthy (CT) \\ Paul Merges (NY) \\ Charles R. Meyer (TX) \\ Steven Oberg (ID) \\ Henry Porter (SC) \\ Richard Ratliff (TX) \\ Gary Robertson (WA) \\ Marjorie Wallé (IL) \\ Ken Weaver (CO)
}

Many other state radiation control program staff also assisted, including Jamil Ahmad (WA), Pat Dostie (ME), Dave Ed (IL), Mikel Elsen (WA), Kristin Felix (WA), Joe Jones (NY), Hank Kocol (CA), and William Tetley (NY). Each, especially Pat and Joe, has volunteered significant expertise.

Special thanks are thus due to the directors of the state radiation control programs who either encouraged the participation of their staff in Committee E-5 efforts or, being from a state hosting a site, provided much of the information on which this summary report is based.

Reviewers familiar with particular site histories have included Bill House and Jim Shaffner, as well as Frank Bordell, Stan Huber, Carl (Ed) Johnson, Art Palmer, and Stewart Thompson.

Committee federal resource persons have included Jim Gruhlke of the U.S. Environmental Protection Agency, Ed Regnier of the U.S. Department of Energy, and Joe Kane, Paul Lohaus, Bill Lahs, and John Thoma from the U.S. Nuclear Regulatory Commission. Without Mr. Lohaus' longstanding encouragement, this dauntingly difficult endeavor would not have been completed. 
Essential support also came from the office of the Conference of Radiation Control Program Directors, Inc., particularly from Pat Gorman, Executive Director Chuck Hardin, and Terry Devine.

The final push in editing and publishing this report came from staff of the U.S. Department of Energy's National Low-Level Waste Management Program, especially Don Harmon and Tom Kerr as well as Bill Newberry, Roger Scott, and Phil Wheatley.

This compilation and presentation of environmental monitoring information for commercial low-level radioactive waste disposal sites in the United States is the collective volunteer effort of state staff, federal resource persons and affiliate advisors serving with CRCPD's Committee on Radioactive Waste Management. It has no individual author or authors. This report was completed in the spirit of cooperation and partnership which represents CRCPD at its best and most uniquely productive activity.

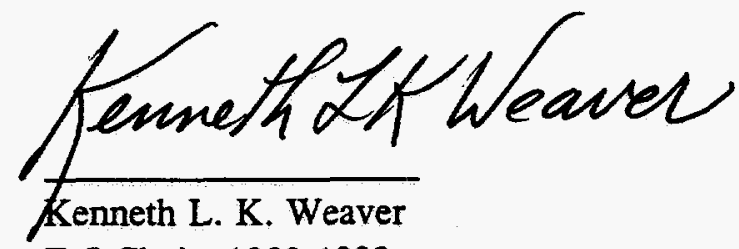

E-5 Chair, 1989-1993

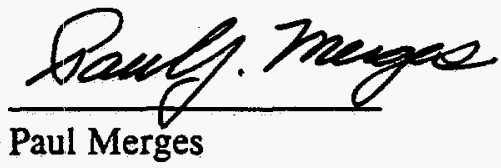

E-5 Chair, 1993-1995 


\section{CHAPTER 1}

\section{Environmental Monitoring Report for Commercial Low-Level Radioactive Waste Disposal Sites}

\section{ENVIRONMENTAL MONITORING PERSPECTIVES}

Environmental monitoring results have always been the most significant quantitative measure of low-level radioactive waste (LLW) disposal facilities' compliance with regulatory standards. In this report, the E-5 Committee on Radioactive Waste Management of the Conference of Radiation Control Program Directors (CRCPD) has assembled environmental monitoring results from the six commercial LLW disposal facilities which have operated within the United States.

The environmental results included in this report are not new. Except for the more recent measurements reported herein, results presented in this report have been available for many years and were used as evidence of regulatory compliance for the facilities they represent based upon the standards and regulations existing during applicable eras. Historically, many of these data were used by regulatory professionals to determine compliance status. The perspective that forms the conclusions in this report about site performance is one which looks back at the data from the 1960's through the early 1990 's.

The data for air, water, soil, and vegetation summarized in this report vary from site to site in both the time period covered and the level of detail. While comparisons between and among some data. sets are appropriate, this must be done with care and caution. Differences in the time periods represented, the media sampled, and the types and level of analyses limit the ability to make meaningful comparisons. In this report, comparative analyses are limited to sets of data representing specific media for a specific site. Because of the data available, different statistical parameters (e.g., means, extremes, variances) were used for different subsets of data.

Environmental monitoring programs have significantly evolved and improved since the 1960's. Changes have occurred in the nature and frequency of sampling, sampling and analysis protocols, media sampled, quality assurance/quality control (QA/QC), and perhaps most importantly, the regulatory framework within which environmental monitoring occurs.

In the early days of environmental monitoring, samples were collected almost on an ad hoc basis, often with limited sampling procedures. Few, if any, protocols were employed for sample handling, packaging, shipping, or receipt inspection. Analytical laboratories made few quality control checks during sample preparation or analytical procedures. Counting equipment was less sophisticated than today's equipment. The lower limits of detection (LLDs) for results were several orders of magnitude greater than those available and used today. Required analyses were often limited to gross indicator parameters such as alpha, beta, and sometimes tritium. Trend analyses of results were often limited to 
very basic statistical parameters. In contrast, sophisticated computer software codes now rapidly produce results which used to involve many weeks' worth of time.

Still, results were used as they are today for comparison with a regulatory standard or fraction thereof. If the standard was exceeded, action was mandated. In this regard, all references to compliance with regulatory standards in this report are made relative to regulatory standards in effect at such time as measurements were made or environmental samples were collected and analyzed.

The scope of environmental monitoring programs has changed significantly for the next generation of LLW sites.

Current regulations call for extensive pre-operational baseline environmental monitoring to establish a basis against which to measure future monitoring results. Naturally occurring radioactive material is often present in the soil, air, vegetation, and water under pristine conditions in concentrations at or near levels of significance for today's LLW sites. When no baseline monitoring is performed, little basis exists for back-comparison of sampling results.

Today's sampling protocols are sophisticated compared to the days of extracting samples by the best of a limited number of methods available. Today there are rigorous procedures for sample collection and preservation as well as procedures to eliminate cross contamination from one sample to another.

Currently, a multi-tiered system is used to look at environmental results:

- An investigating level, typically tied statistically to the baseline mean or multiple of an LLD, may trigger an increased awareness and watchfulness regarding a specific radionuclide. Data at this level may also lead to more investigation, explanation, and more frequent or detailed analyses.

- An action level, typically some fraction of a regulatory limit, implies proactive response on the part of a licensee to mitigate the circumstances, usually involving administrative controls, impact analysis, and sometimes, increased regulatory oversight.

- Regulatory limits, if exceeded, call for immediate regulatory action, such as mitigation, enforcement actions, or cessation of operations.

Because of the complexity of all phases of environmental monitoring, sampling, packaging, shipping, analysis, recording, and reporting, many opportunities exist for data errors on individual results. This increases the need for rigorous validation and verification. Such validation and verification were not always part of the process, so some individual data results must be viewed with caution.

Often, the only recourse to sample anomalies was to re-sample the same media at the same location and analyze the sample. If the facility program called for replicate sampling, the other recourse was to run a duplicate analysis on the backup sample. 
All data must be reviewed in context. There is often a temptation, particularly in a highly politicized and controversial arena, to take one result as representative of the actual situation. A properly designed monitoring program will emphasize the relationship between samples for different time periods and even for results from different media. Sampling results should be scrutinized within the context of known physical relationships. For example, certain nuclides are known to exist in expected ratios with one another in specific media. If data suggest deviation from these ratios, the results are suspect.

Often, older data do not allow deeper analysis because only gross indicator parameters were collected. Therefore, some of the tools for data validation were absent.

\section{Gross alpha and beta:}

Early radiological reporting relied heavily on using screening techniques such as gross alpha and beta levels as indicators that radionuclides were present above some predetermined level. These parameters were reported rather than specific radionuclides, because, at that time, there were few facilities that maintained the more costly equipment necessary to perform gamma or alpha spectroscopy. If increases in gross alpha and beta levels were observed, samples could be sent to off-site laboratories for more specific analyses.

Gross alpha and beta measurements are still frequently made and occasionally still used as screening criteria. However, even small laboratories can now afford spectral analysis and, as a result, specific radionclides are reported instead of just the gross alpha and beta results.

\section{Tritium:}

Tritium is an isotope of hydrogen, which has an atomic mass of three, two neutrons and one proton. Tritium is worthy of note because, in the form of its oxide, it is one of the most mobile of the radionuclides likely to be found in radioactive waste, will probably be present as a significant fraction of the total activity of the radioactive waste, and has a half-life of 12.3 years. Therefore, tritium would be the most likely radionuclide to be detected first should waste be transported by ground water out of the disposal area at a shallow land disposal facility.

Studies at the Hanford site and other locations have demonstrated that tritium in ground water will move in the same direction and at the same rate as the ground water (with some slight retardation in clay). ${ }^{\mathrm{a}}$

Certain behavioral trends within certain media for migration of certain radionuclides are known and expected. Significantly different behavior patterns are subject to question. For instance, tritium concentrations associated with a "chronic" site release are expected to gradually increase with time to a steady state condition (known as "buildup") then gradually dissipate as radioactive decay takes place.

a. National Low-Level Waste Management Program Radionuclide Report Series, Volume 5: Tritium, Idaho National Engineering Laboratory, Idaho Falls, Idaho, 1994. 
The E-5 Committee decided to keep tables of data in the units originally reported. Most of the discussion in the narrative text follows CRCPD's policy of listing values using the International System of Units (with conventional units in parentheses), but in some sections the historical units were kept for clarity. Conversion units are provided in Table 1-1 for convenience in converting units for comparison of results appearing throughout the report.

Table 1-1. Conversion units.

\author{
Activity $^{\mathbf{a}}$ \\ $\mathrm{pCi}=\mu \mathrm{Ci} \times 1.0 \mathrm{E}-06$ \\ $\mathrm{pCi}=\mathrm{nCi} \times 1.0 \mathrm{E}-03$ \\ $\mathrm{pCi}=\mathrm{fCi} \times 1.0 \mathrm{E}+03$ \\ $37 \mathrm{GBq}(37 \mathrm{E}+09 \mathrm{~Bq})=1 \mathrm{Ci}$ \\ $37 \mathrm{mBq}=1 \mathrm{pCi}$ \\ $1 \mathrm{~Bq}=27 \mathrm{pCi}$ \\ $37 \mathrm{kBq}=1 \mu \mathrm{Ci}$ \\ $1 \mu \mathrm{Ci} / \mathrm{L}=37 \mathrm{kBq} / \mathrm{L}$ \\ $10 \mu \mathrm{Ci} / \mathrm{L}=370 \mathrm{kBq} / \mathrm{L}$ \\ $100 \mu \mathrm{Ci} / \mathrm{L}=1000 \mathrm{kBq} / \mathrm{L}$ \\ Dose \\ $100 \mathrm{rem}=1$ sievert $(\mathrm{Sv})$ \\ $1 \mathrm{rem}=10 \mathrm{mSv}$ \\ $1 \mathrm{mrem}=10 \mu \mathrm{Sv}$ \\ $100 \mathrm{rads}=1$ gray $(\mathrm{Gy})$ \\ $1 \mathrm{rad}=10 \mathrm{mGy}$ \\ $1 \mathrm{mrad}=10 \mu \mathrm{Gy}$

\section{Temperature} \\ ${ }^{\circ} \mathrm{F}=\left({ }^{\circ} \mathrm{C} \times 9 / 5\right)+32=\left({ }^{\circ} \mathrm{C} \times 1.8\right)+32$ \\ ${ }^{\circ} \mathrm{C}=\left({ }^{\circ} \mathrm{F}-32\right) 5 / 9=\left({ }^{\circ} \mathrm{F}-32\right) 0.556$
}

\section{Activity Concentration}

$\mathrm{Ci} / \mathrm{mL}=(\mathrm{E}+15) \mathrm{pCi} / \mathrm{L}$

$\mathrm{Ci} / \mathrm{mL}=(\mathrm{E}+18) \mathrm{pCi} / \mathrm{m}^{3}$

Mass

pounds $=0.4536$ kilogram $(\mathrm{kg})$

pounds $(\mathrm{lb})=453.6$ grams (gm)

kilograms $(\mathrm{kg})-2.21$ pounds

\section{Length}

inches $=2.54$ centimeters $(\mathrm{cm})$

centimeters $(\mathrm{cm})=0.394$ inch

millimeters $=0.001$ meter

feet $=0.305$ meters $(\mathrm{m})$

meters $(\mathrm{m})=3.281$ feet $(\mathrm{ft})$

miles $=1.609$ kilometers $(\mathrm{km})$

kilometers $(\mathrm{km})=0.6214$ mile

1 hectare $=$ square kilometer $\div 100$

Area

acre $=43,560$ square feet $\left(\mathrm{ft}^{2}\right)$

hectares $=2.471$ acres

square feet $\left(\mathrm{ft}^{2}\right)=0.0929$ square meter $\left(\mathrm{m}^{2}\right)$

square meter $\left(\mathrm{m}^{2}\right)=10.76$ square feet $\left(\mathrm{ft}^{2}\right)$

square inches $\left(\mathrm{in}^{2}\right)=0.00065$ square meter $\left(\mathrm{m}^{2}\right)$

square inches $\left(\mathrm{in}^{2}\right)=6.45$ square centimeter $\left(\mathrm{cm}^{2}\right)$

\section{Volume}

cubic feet $\left(\mathrm{ft}^{3}\right)=0.0283$ cubic meter $\left(\mathrm{m}^{3}\right)$

cubic meter $\left(\mathrm{m}^{3}\right)=35.31$ cubic feet $\left(\mathrm{ft}^{3}\right)$

liters $(\mathrm{L})=1000$ cubic centimeters $(\mathrm{cc})$

cubic centimeter $(\mathrm{cc})=0.001$ liter $(\mathrm{L})$

liters $(\mathrm{L})=100$ centiliters $(\mathrm{cL})$

gallons $=3.785$ liters $(\mathrm{L})=0.1337 \mathrm{ft}^{3}$

cubic centimeter $(\mathrm{cc})=1$ milliliter $(\mathrm{mL})$

Time

days $=1440$ minutes $=86,400$ seconds

years $=3.15 \mathrm{E}+07$ seconds

\section{Velocity}

miles per hour $(\mathrm{mph})=44.70 \mathrm{~cm} / \mathrm{sec}$

$\mathrm{cm} / \mathrm{sec}=0.0360 \mathrm{~km} / \mathrm{hr}$

$\mathrm{ft} / \mathrm{min}=0.508 \mathrm{~cm} / \mathrm{sec}$ 
Table 1-1. (continued).

\begin{tabular}{|c|c|c|c|c|c|}
\hline a & atto & E-18 & $\mathrm{k}$ & kilo & $E+03$ \\
\hline$f$ & femto & E-15 & $\mathbf{M}$ & mega & $E+06$ \\
\hline 0 & pico & $\mathrm{E}-12$ & G & giga & $E+09$ \\
\hline & nano & E-09 & $\mathrm{T}$ & tera & $E+12$ \\
\hline & micro & E-06 & $\mathbf{P}$ & peta & $E+15$ \\
\hline 0 & milli & E-03 & $\mathrm{E}$ & exa & $E+18$ \\
\hline
\end{tabular}

a. For powers of ten, the notation $10^{6}$ or $10^{-6}$ is the same as $\mathrm{E}+06$ or $\mathrm{E}-06$.



Figure 1-1. Location of the six commercial LLW disposal facilities discussed in this report.

\section{Purpose and Organization of Report}

Six commercial LLW disposal facilities have been operated in the United States (see Figure 1-1). All are now regulated by states under agreements with the U.S. Nuclear Regulatory Commission 
(NRC). Such states are referred to as Agreement States. The NRC still licenses special nuclear material at the Barnwell and Richland sites in coordination with the host state.

This report summarizes each site's (1) general design, (2) environmental monitoring program and the data obtained as the program has evolved, and (3) what the program has indicated about releases to off-site areas, if any, including an estimate of the actual health and safety significance of any releases.

Three sites have been closed since the mid-1970's: West Valley, New York (1975), Maxey Flats, Kentucky (1977), and Sheffield, Illinois (1978). The Beatty, Nevada site closed at the end of 1992. The Barnwell, South Carolina site has plans to remain open to nationwide LLW generators for the next several years. The Richland, Washington site receives LLW from only generators in the Northwest and Rocky Mountain compact regions.

The sites are discussed Chapter-by-Chapter in alphabetical order by host state.

Chapter 2 Sheffield, Illinois

Chapter 3 Maxey Flats, Kentucky

Chapter 4 Beatty, Nevada

Chapter 5 West Valley, New York

Chapter 6 Barnwell, South Carolina

Chapter 7 Richland, Washington 


\title{
CHAPTER 2
}

\section{Environmental Summary of the Sheffield, Illinois Low-Level Radioactive Waste Disposal Site}

\author{
INTRODUCTION
}

\section{Background}

The Sheffield low-level radioactive waste (LLW) disposal site operated by NECo, and its successor, US Ecology, from 1966 to $1978 .^{2-1}$ During that time, about 3.2 million cubic feet of lowlevel radioactive waste were buried in 21 earthen trenches.

Disposal operations were regulated under the provisions of a license issued by the U.S. Atomic Energy Commission which later became the U.S. Nuclear Regulatory Commission. The State of Illinois regulated the site under the provisions of a license and lease issued by the Illinois Department of Public Health. The lease was necessary because federal law required that low-level radioactive waste be disposed on government-owned land and, accordingly, the 20-acre LLW site was (and is) owned by the state. In 1980, the state's regulatory functions dealing with the LLW site were transferred to the newly created Department of Nuclear Safety. Regulation of the adjoining hazardous chemical sites is the responsibility of the Illinois Environmental Protection Agency.

In 1979 , the site operator attempted to unilaterally terminate its state and federal licenses and the state lease. Both state and federal regulators objected to the unilateral terminations, arguing that the site operator must first safely close the site before terminating either of the licenses. The state further argued that the term of its lease with the site operator was 99 years (expiring in 2065) and that the lease could not be unilaterally terminated until then.

All of this resulted in both federal and state litigation. The federal litigation was administratively argued before the Atomic Safety and Licensing Board which eventually ruled against the operator on all counts. The state's complaint was argued before the Bureau County Circuit Court. After ten years of negotiation, the state and the site operator came to agreement about how the site was to be safely closed and the litigation was resolved in the form of an Agreed Order, signed May 25, 1988. Illinois became an Agreement State on June 1, 1987. At that time, the Atomic Energy Act licensing authority for the Sheffield site was transferred to the Illinois Department of Nuclear Safety.

\section{Location}

The Sheffield commercial low-level radioactive waste disposal facility is located in Bureau County, Illinois. The Sheffield LLW site is south of Interstate Highway 80 about $200 \mathrm{~km}$ (120 mi) west of Chicago, about $65 \mathrm{~km}$ (40 mi) northwest of Peoria, and $60 \mathrm{~km} \mathrm{(35} \mathrm{mi)} \mathrm{east} \mathrm{of} \mathrm{Rock}$ Island/Moline (Figure 2-1). 


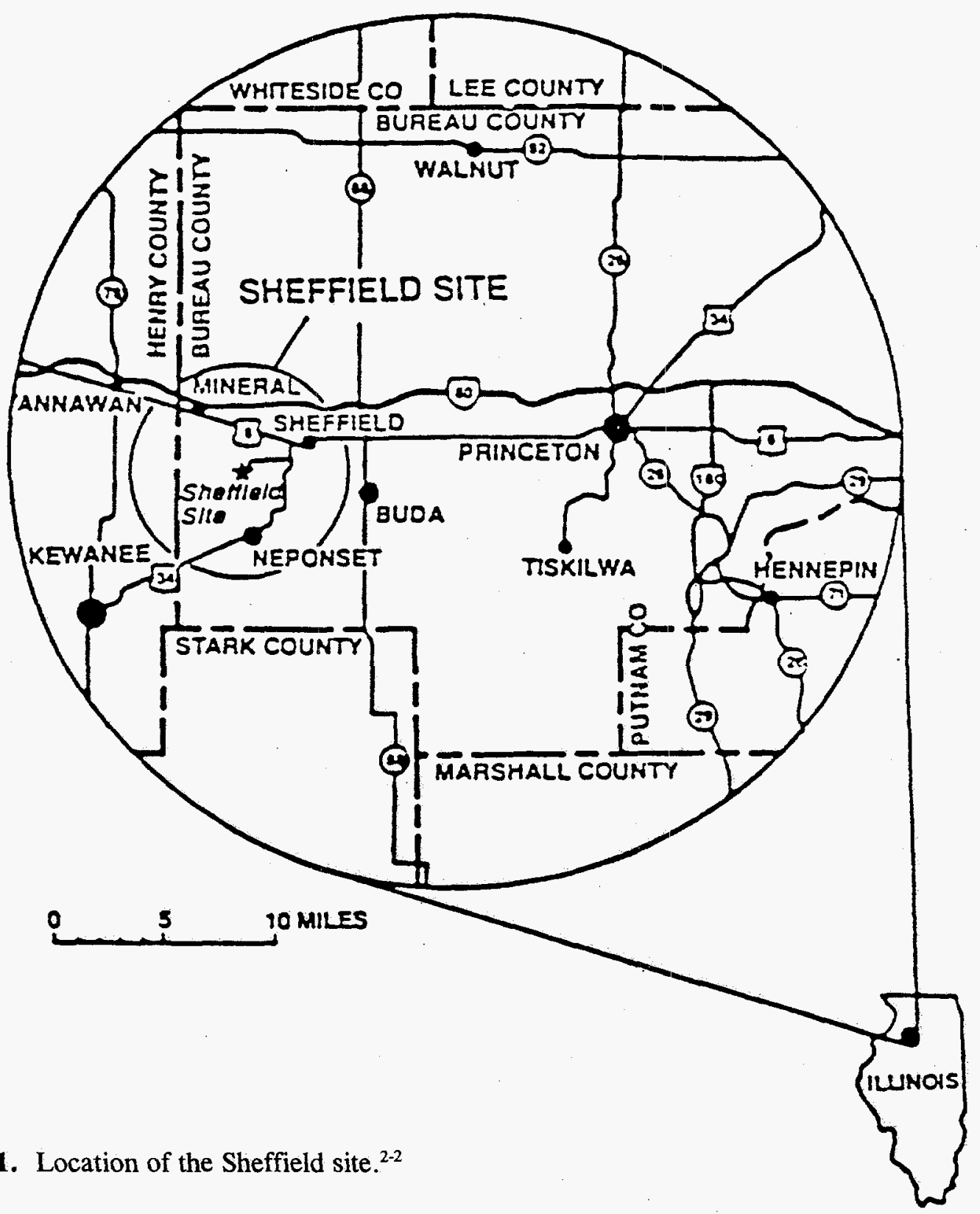

Two hazardous chemical waste disposal areas are to the north and northwest of the radioactive waste disposal site (Figure 2-2), separated from the radioactive waste site by approximately $45 \mathrm{~m}$ $(150 \mathrm{ft})$. The first area accepted hazardous chemical waste from 1968 to 1974 and the second area from 1974 to 1983.

\section{Facility}

The Sheffield LLW site first received wastes in 1967 and operated until the 21 trenches were full in 1976. The disposal trenches were generally in parallel with a buffer approximately $3 \mathrm{~m}$ (10 ft) wide

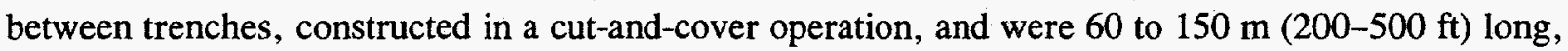

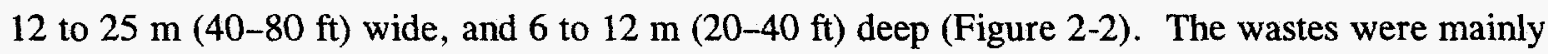
packaged in steel drums, fiberboard boxes, fiberboard drums, and steel liners. 


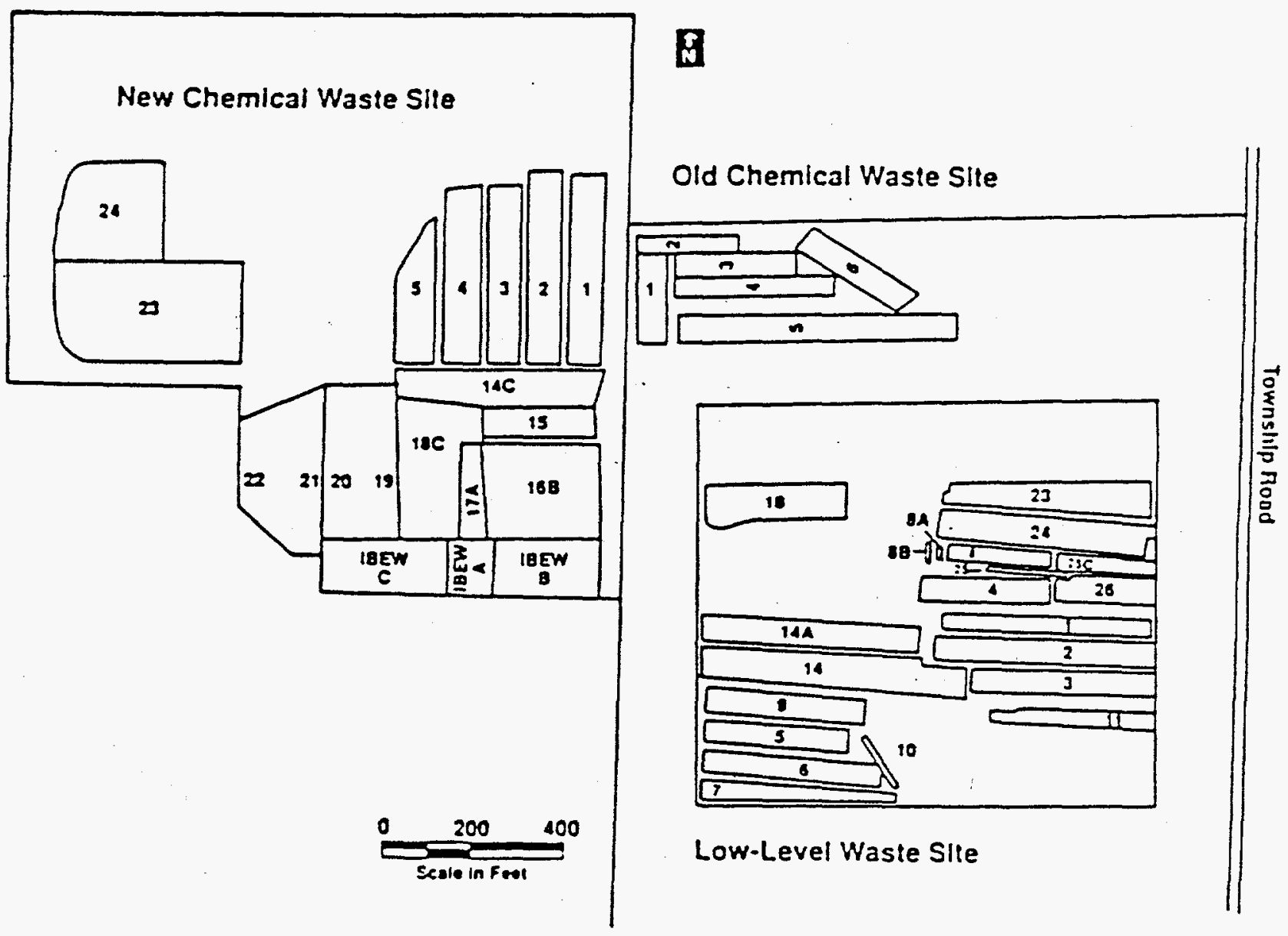

Figure 2-2. Plan view of Sheffield low-level radioactive waste and chemical disposal areas. ${ }^{2-2}$

\section{Volume}

The estimated $88,000 \mathrm{~m}^{3}\left(3,100,000 \mathrm{ft}^{3}\right)$ total inventory is listed in Table $2-1$. Three separate studies ${ }^{2-3,2-4,2-5}$ have estimated the isotopic inventory since the site operator was not required to keep a precise inventory of radioactive waste buried in each trench. The more than 61,000 curies of radioactive waste consisted primarily of tritium, strontium- 90 , cesium-137, and cobalt-60, with lesser amounts of carbon-14, iodine-129, plutonium, and americium.

\section{Stabilization and Closure}

The 1988 Agreed Order between US Ecology (NECo's successor) and the Illinois Department of Nuclear Safety specifies what the site operator must do to safely close the site and assure its continuing safety into the future. The closure plan requires the operator to: 
1. Construct a new low-permeability (less than $10^{-7} \mathrm{~cm} / \mathrm{s}$ ) clay cap over all the trenches. Cap construction began and was completed in 1989.

2. Purchase a $170+$ acre buffer zone around the site.

3. Monitor and maintain the site and buffer zone until June 1998, when responsibility will transfer to the state. To compensate the state for its future obligations at the site, the operator must pay $\$ 2.5$ million in quarterly installments of $\$ 62,500.00$ over a ten year period (1988-1998). These monies, plus accrued interest, remain on deposit in a special fund of the state treasury reserved exclusively for Sheffield-related expenses..$^{2-6}$

4. Take remedial action as needed to prevent discharge beyond the buffer zone of radioactive materials in excess of Illinois Department of Nuclear Safety limits. The operator has established financial assurance in the form of an irrevocable letter of credit for \$1.9 million for remedial action. ${ }^{2-6}$

Table 2-1. Estimated key radionuclides (half-lives greater than five years) at the Sheffield site.

\begin{tabular}{lcc}
\hline Radionuclide & $\begin{array}{c}\text { Activity (Ci) at time } \\
\text { of emplacement }\end{array}$ & $\begin{array}{c}\text { Half-life } \\
\text { (y) }\end{array}$ \\
\hline H-3 & $5,990$. & 12.3 \\
C-14 & 450. & $5,730$. \\
I-129 & 0.01 & $15,700,000$. \\
Sr-90 & $3,690$. & 29.1 \\
Cs-137 & $15,500$. & 30.17 \\
Co-60 & $20,000$. & 5.27 \\
Pu-238 & 7.5 & 87.7 \\
Pu-239 & $4,870$. & $24,100$. \\
Pu-240 & - & $6,560$. \\
Pu-241 & - & 14.4 \\
Am-241 & 137.5 & 432.7 \\
\hline
\end{tabular}

a. Permeability is expressed as hydraulic conductivity measured in units of centimeters per second $(\mathrm{cm} / \mathrm{sec})$. $10^{-7} \mathrm{~cm} / \mathrm{sec}$ is equivalent to one-tenth of one-millionth of a centimeter per second. A centimeter is a measure of length equal to about 0.4 inch. Converting units, $10^{-7} \mathrm{~cm} / \mathrm{sec}$ equates to about 1.25 inches per year.

b. Chart of the Nuclides, 14th ed., updated through April 1988. 


\section{SITE}

\section{Topography}

The Sheffield site is located on rolling terrain (the Galesburg Rolling Plain) in north-central Illinois approximately $5 \mathrm{~km}(3 \mathrm{mi})$ southwest of the town of Sheffield. The landforms in this region of hilly terrain are primarily of glacial origin. Surface mining operations during the 1950 s produced some areas of pronounced ridges and valleys.

\section{Climate}

The regional climate in Bureau County, Illinois, is continental with summer highs around $32^{\circ} \mathrm{C}$ $\left(100^{\circ} \mathrm{F}\right)$ and winter lows of $-26^{\circ} \mathrm{C}\left(-13^{\circ} \mathrm{F}\right)$. January is usually the coldest month of the year with July and August usually being the warmest.

Annual precipitation at surrounding weather stations ranges from a minimum of $65 \mathrm{~cm} \mathrm{(25} \mathrm{in.)} \mathrm{to}$ a maximum of $130 \mathrm{~cm}$ (52 in.), with a long-term average of $89 \mathrm{~cm}(35 \mathrm{in} .)^{2-7}$ Convective thunderstorms dominate the summer months, May through September, when most of the precipitation falls. The wettest month is June, averaging $11.6 \mathrm{~cm} \mathrm{(4.5} \mathrm{in.),} \mathrm{and} \mathrm{the} \mathrm{driest} \mathrm{month} \mathrm{is} \mathrm{February,}$ averaging $3.3 \mathrm{~cm}(1.3 \mathrm{in}$.). The average annual snowfall is $850 \mathrm{~cm}(33.5 \mathrm{in}$.). The relative humidity for the area averages about 70.6 percent.

\section{Land Use}

The approximately 70 hectare (170 acre) buffer area owned by US Ecology, which surrounds the 8.3 hectare (20.5 acre) radioactive waste disposal facility (Figure 2-2), is used for industrial waste disposal ( 16 hectare) and farm leases ( 48.8 hectare); it includes a small abandoned coal mine pit, called Trout Lake, and a small stream to the south and southeast of the site. The areas south of the site are used primarily for agriculture (crops and pasture).

The Sheffield site is bordered to the north by abandoned strip mines and the industrial waste

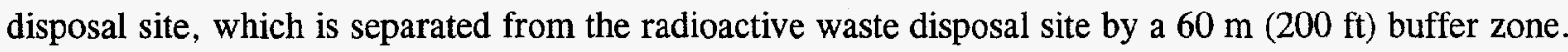
Approximately $400 \mathrm{~m}(1,300 \mathrm{ft})$ east-northeast of the site is a strip mine lake which resulted from the surface mining operations. To the north and to the northeast and northwest are abandoned coal pits that are filled with water. These manmade lakes are restricted and not used for fishing, swimming, or boating.

Seventeen residences are within a $3 \mathrm{~km}(2 \mathrm{mi})$ radius of the Sheffield site. Sheffield, population 1,052 , is $5 \mathrm{~km}(3 \mathrm{mi})$ to the northeast. The unincorporated town of Mineral, population 286 , is $8 \mathrm{~km}$ ( $5 \mathrm{mi}$ ) to the northwest. The town of Neponset, population 509 , is $5 \mathrm{~km}$ ( $3 \mathrm{mi}$ ) south.

\section{Geology}

The Sheffield LLW disposal site is located in the glaciated till plain section of the Central Lowlands Physiographic Province. Test drilling has indicated that the Sheffield site is underlain by a 
complex series of interbedded and interfingering glacial sediments. The disposal trenches cut through a complex series of quaternary deposits (Figures 2-3 through 2-5), which are composed primarily of silts, clays, and sands ranging in thickness from 3 to $20 \mathrm{~m}(10-65 \mathrm{ft})$.



\section{Explanation}

- Observation Well

A _ A' Line Of Section

Figure 2-3. Location of geologic cross section for the Sheffield site. ${ }^{2-8}$ 
Soils Within

the Unsaturated Zone
Soils Within

the Saturated Zone
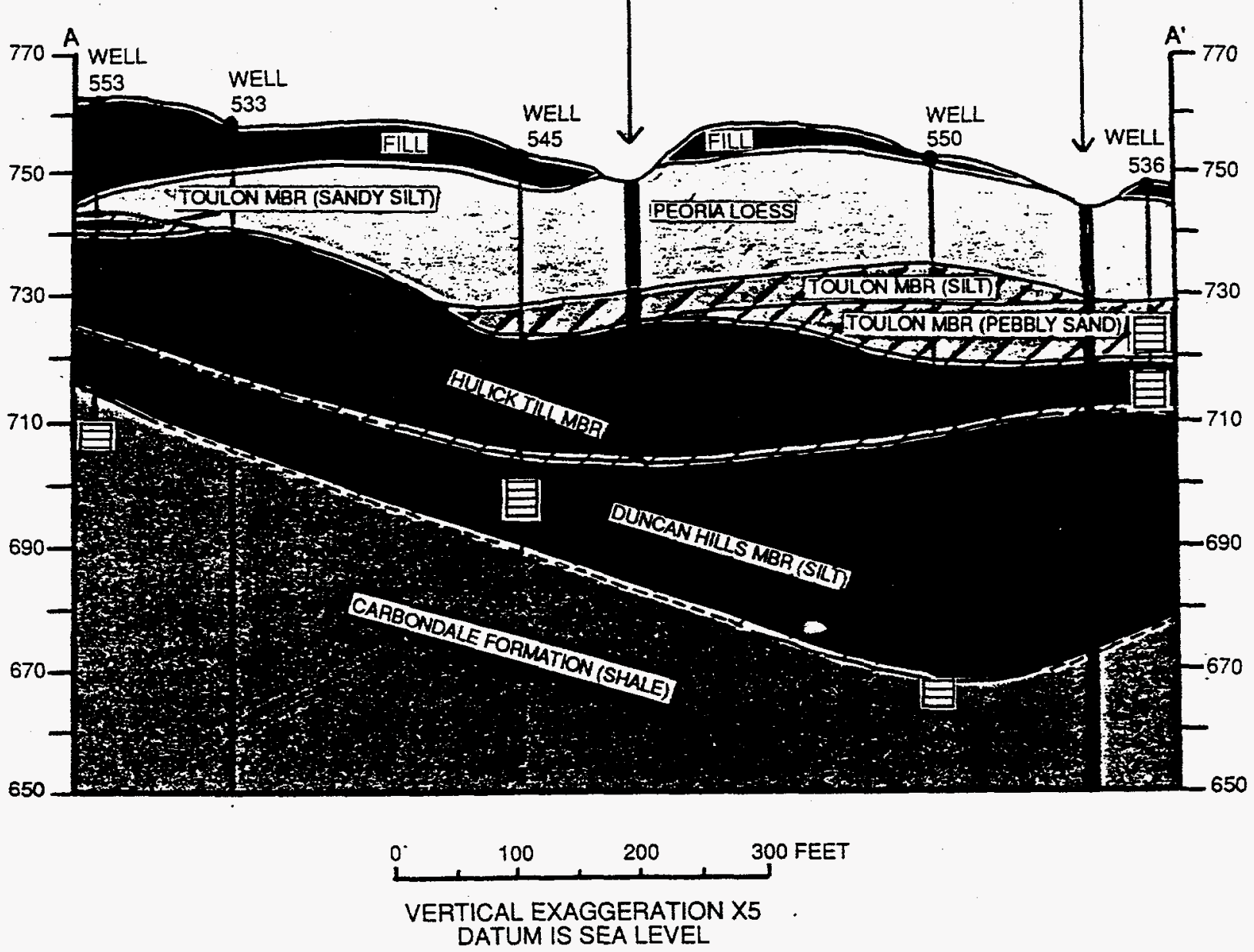

Geologic Section A - A' of Sheffield Site

EXPLANATION

Ed GLASFORD FORMATION

SCREENED SECTION OF WELL

WELL DESIGNATION

Figure 2-4. Geologic cross section for the Sheffield site..$^{2-8}$ 


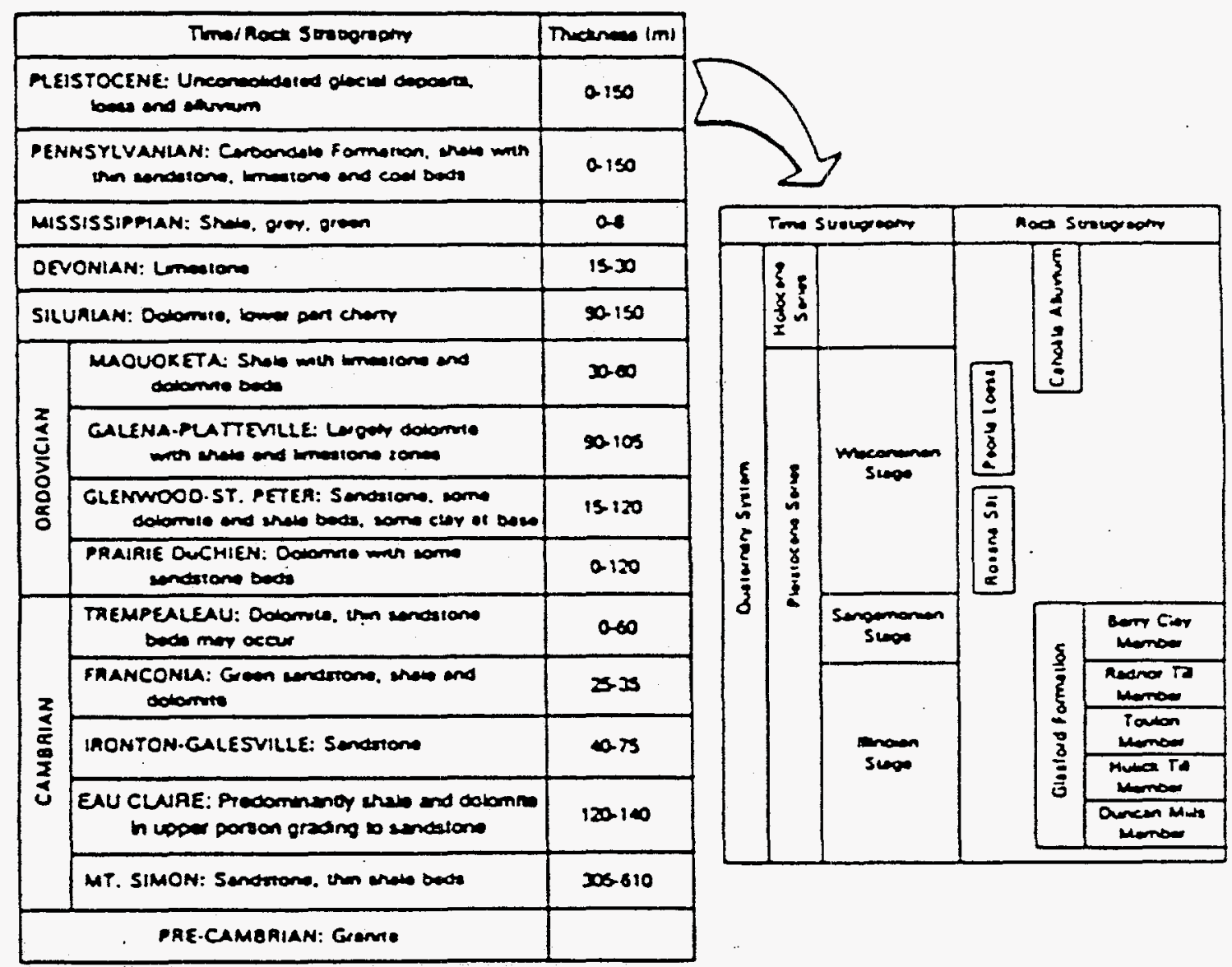

Figure 2-5. Stratigraphy of northern Illinois and the Sheffield site. ${ }^{2-2}$

In ascending order and beginning with the bedrock, the stratigraphy of the site includes the weathered shale of the Carbondale Formation, the Duncan Hills Member, the Hulick Till Member, the Toulon Member, the Radnor Till Member, and the Berry Clay Member of the Glasford Formation (all bedrock); the Roxana Silt; the Peoria Loess; and the Cahokia Alluvium. More recent units on the site include a modern soil and coal mine spoils.

\section{Surface Water}

The two major drainage features of western Illinois are the Mississippi and Illinois Rivers. The Sheffield site is located within the Mississippi River Basin near the drainage divide between two creeks, Lawson Creek and King Creek. The divide separating the Illinois and Mississippi drainage basins runs in a northeasterly direction about $1.5 \mathrm{~km}(1 \mathrm{mi})$ south of the site and passes through the town of Kewanee about $11 \mathrm{~km}(7 \mathrm{mi})$ southwest of the site.

The small, intermittent (ephemeral) streams draining the site formerly discharged to the abandoned coal mine pit $400 \mathrm{~m}(1,250 \mathrm{ft})$ east-northeast, but now discharge downstream of this strip mine lake (Figure 2-6). Lawson Creek eventually discharges to the Green River, about $15 \mathrm{~km}$ (10 mi) north of the site. The Green River flows westerly to the confluence with the Rock River near Moline, Illinois, where the Rock River joins the Mississippi River. 


\section{Ground Water}

Two aquifer systems lie beneath the Sheffield site each with a different direction of flow (Figure 2-7). A regional confined aquifer system is contained in deep sandstone and carbonate bedrock. The local aquifer system contains ground water mainly under water table conditions. This shallow, unconfined aquifer, which is in unconsolidated deposits comprised of weathered shale, till, and alluvium and ranging from 1.5 to $14 \mathrm{~m}(5-46 \mathrm{ft})$ thick, is generally of low permeability. The shallow

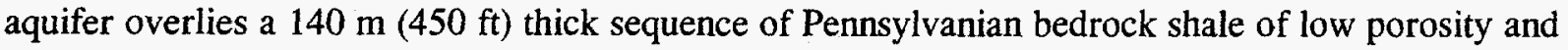
permeability.

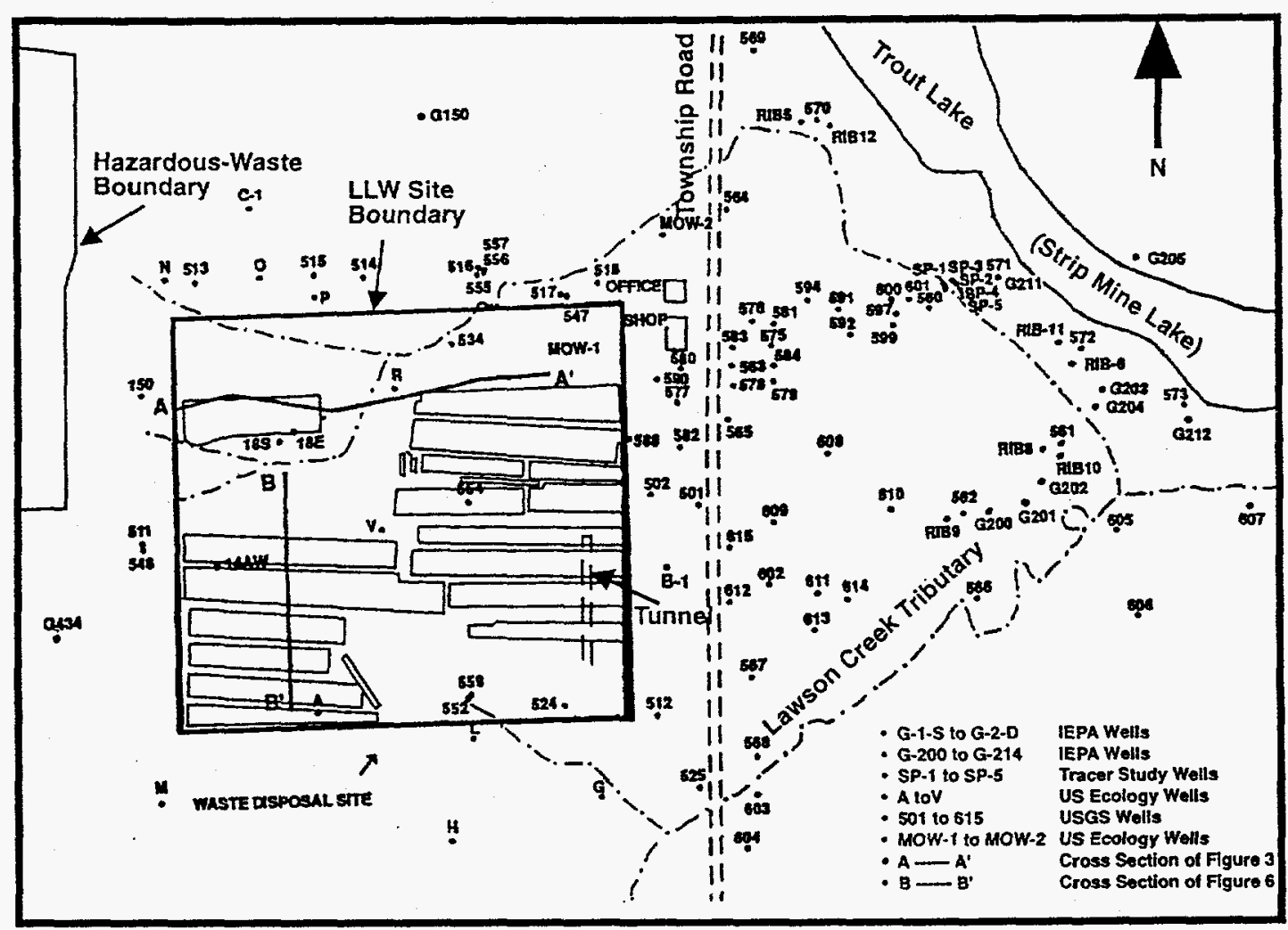

Figure 2-6. Map of well locations, trenches and tunnels at the Sheffield site..$^{2-2}$

The groundwater is recharged in the topographically high areas in southeast and southwest portions of the site. It flows toward discharge areas along the unnamed tributary to Lawson Creek and the strip mine area. The site aquifer is recharged locally from the direct precipitation falling on and immediately west of the site, infiltration in areas where loess is thin or absent, and downward percolation through the loess.

The depth to water beneath the site ranges from 1.8 to $6 \mathrm{~m}(6-20 \mathrm{ft})$. Flow in the shallow aquifer is within three ground water basins. The aquifer's configuration is similar to surface topography. Ground water movement is generally in two predominant directions (Figure 2-7); (1) northeast to east toward Trout Lake, a strip mine lake, and (2) south to southeast toward small tributary channels belonging to Lawson Creek, which formerly drained into Trout Lake. Ground water flow divides are 


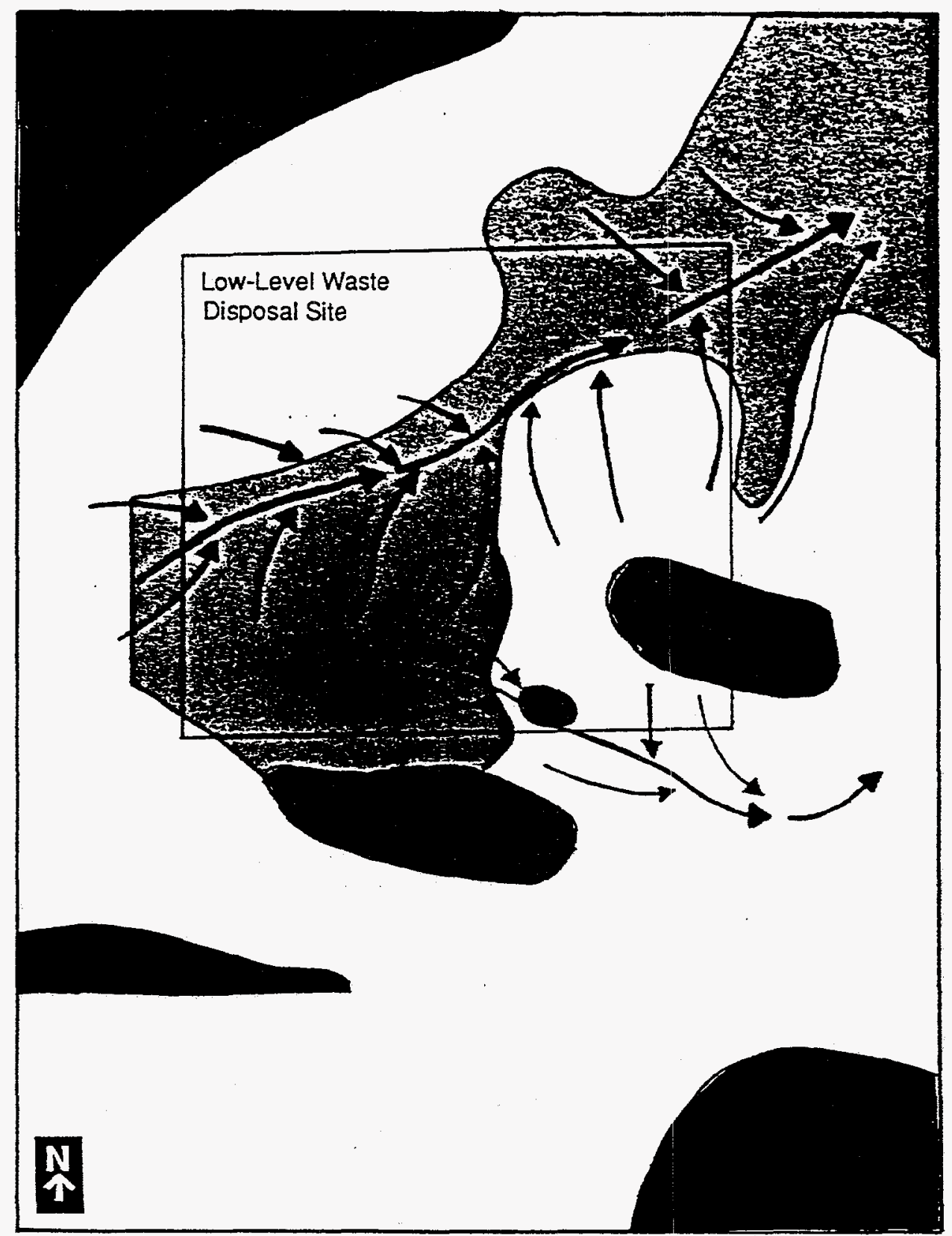

Base from U.S. Geological Survey. 1979

o

200

400 FEET EXPLANATION

BEDROCK

Area where bedrock elevation is at or above the water table

PEBBLY-SAND UNIT Partially or completely saturated $\uparrow$

PRIMARY FLOW PATH

SECONDARY FLOW PATH

Figure 2-7. Ground water flow boundaries, direction of flow and principal flow paths for the Sheffield site..$^{2-8}$ 
found west of the disposal facility, north of the facility in strip mine spoil materials, and on a topographic high found in the southeast corner of the site.

Ground water moves from the hill areas toward the valleys to the north and south. As it approaches the axis of the valley, flow direction changes to the east. Moisture infiltrating the surficial sediments and underflow from the area adjacent to the western disposal site boundary provides all the water moving through the shallow ground water system. The ground water gradients are relatively flat over much of the site. The maximum ground water fluctuations in the disposal area are generally less than $3 \mathrm{~m}$ (10 ft). Larger fluctuations may occur in recharge areas where the depth to ground water is greatest. The depth to ground water was found to be usually less than $3 \mathrm{~m}(10 \mathrm{ft}$ ) in the areas of the unnamed tributary to Lawson Creek and the strip mine area.

Precipitation, which annually averages just under $90 \mathrm{~cm}$ (35 in.), is the source of recharge for the shallow hydrogeologic system and yields approximately $5 \mathrm{~cm}(2 \mathrm{in}$.) of recharge per year. Over the 8 hectare (20.5 acre) disposal site, this translates to roughly one million gallons of moisture penetrating the soil of the shallow hydrogeologic system. Runoff is estimated to be $23 \mathrm{~cm}$ (9 in.) per year and evapotranspiration accounts for $60 \mathrm{~cm}$ ( 24 in.) per year. Trench covers installed prior to 1988 to prevent the infiltration of moisture from precipitation were only partially effective. Indications are that water movement into the trenches occurs primarily along the periphery of the cover and secondarily through the center of the cover.

The primary path of the shallow aquifer originates west of the disposal site and extends beneath the upper southwest quadrant through the central northeast quadrant. It is joined by flow from the upper northwest quadrant of the disposal site and migrates in a northeast direction toward Trout Lake where surface discharge is observable as small springs emptying into the lake. This pathway is through a section of the pebbly sand of the Toulon Member which is significant because it connects hydraulically to most saturated and unsaturated sediments on site. The Toulon Member unit underlies 67 percent of the disposal site and is recognized as controlling the flow of ground water through the disposal site. The pathway extending eastward from the northeast corner of the disposal site is through a narrow, channel-like depression in the Hulick Till Member which is filled with course gravelly sand from the Toulon Member. As mentioned previously this channel connects the Sheffield site hydraulically to the lake. The ground water speed through this narrow, short channel has been estimated to be about $750 \mathrm{~m} / \mathrm{y}(2400 \mathrm{ft} / \mathrm{y})$. Due to the connection with the disposal site, tritium was detected in the ground water along the entire channel-like depression, as well as in seeps along the bank of Trout Lake.

The secondary path originates beneath the lower southwest quadrant of the disposal site and flows into the valley to the south through the Peoria Loess silt, but because of smaller flow volume and lower velocities this pathway represents a less significant migration path. This secondary pathway is also controlled by a buried bedrock channel partially filled with pebbly sand. However, the sand in this channel was found to have no relation to the Toulon Member previously identified as a conduit for ground water exiting the disposal site. This sand was found to belong to the Henry Formation, a younger deposit having a lesser potential for significant exit migration along this pathway. 


\section{Ecology}

The area contains woody vegetation, natural grasses, and revegetated grasses. Approximately 20 percent of the site is forested.

A wide diversity of terrestrial vertebrates is found in central Illinois. The habitats available to terrestrial animals on the site include intermittent stream-forest, forest-edge, and disturbed prairie. These systems support various animal and bird species.

Table 2-2 lists some of the vegetation, mammals, and birds found near the Sheffield site in Bureau County.

\section{ENVIRONMENTAL MONITOIRING}

\section{Overview}

Environmental samples were collected at the Sheffield site and analyzed by the site operator and the Illinois Department of Public Health between 1967 and 1980. An ongoing monitoring and surveillance program has been conducted by the Illinois Department of Nuclear Safety since 1980 .

The environmental monitoring program is designed to evaluate the site performance by monitoring any movement, or lack of movement, of tritium and other radionuclides, to evaluate the general environment, and to evaluate any potential or actual exposure to radionuclides. The major part of the environmental monitoring program involved the sampling and analysis of ground water and surface water at or near the site. According to the provisions of the Agreed Order, the limits for discharge beyond the buffer zone were (and will continue to be) those that were in force as of the date the Agreed Order was signed (May 25, 1988).

The following components comprise the Illinois Department of Nuclear Safety monitoring program:

1. Surface water, drinking water, and ground water are sampled at monthly to quarterly intervals, depending on how significant the sampling location is and how frequently it contains sufficient water for sampling. All samples are analyzed for gross alpha, gross beta, and tritium levels. Analysis for specific gamma-emitting radionuclides is performed on those samples found to have elevated alpha or beta levels. Strontium-90 analysis is conducted on those samples with elevated beta levels.

2. Air samples are collected continuously by a low-volume sampler and are analyzed weekly for airborne particulates. 
Table 2-2. Examples of biota found near the Sheffield site.

\begin{tabular}{|c|c|}
\hline Common name & Scientific name \\
\hline \multicolumn{2}{|l|}{ Vegetation } \\
\hline $\begin{array}{l}\text { Bur oak } \\
\text { Hickories } \\
\text { Sumac } \\
\text { Blackberry } \\
\text { Snoberry } \\
\text { Little bluestem } \\
\text { Sideoats grama } \\
\text { Kentucky bluegrass } \\
\text { Orchard grass } \\
\text { Brome } \\
\text { Sweet clover }\end{array}$ & $\begin{array}{l}\text { Quercus macrocarpa } \\
\text { Carya spp. } \\
\text { Rhus sp. } \\
\text { Rubus sp. } \\
\text { Symphoricorpos sp. } \\
\text { Andropogon scoparius } \\
\text { Bouteloua curtipendula } \\
\text { Poa pratensis } \\
\text { Dactylis glomerata } \\
\text { Bromus sp. } \\
\text { Trifoluim sp. }\end{array}$ \\
\hline \multicolumn{2}{|l|}{ Mammals } \\
\hline $\begin{array}{l}\text { Opossum } \\
\text { Raccoon } \\
\text { Badger } \\
\text { Coyote } \\
\text { Red fox } \\
\text { Gray fox } \\
\text { Woodchuck } \\
\text { Eastern gray squirrel } \\
\text { Eastern cottontail } \\
\text { White tailed deer }\end{array}$ & $\begin{array}{l}\text { Didelphis marsupialis } \\
\text { Procyon lator } \\
\text { Taxidea toxus } \\
\text { Canis latrans } \\
\text { Vulpes fulva } \\
\text { Urocyon cinerecargentaus } \\
\text { Marmata monax } \\
\text { Sciurus carolinensis } \\
\text { Sylvilagus floridanus } \\
\text { Odocoileus virginianus }\end{array}$ \\
\hline \multicolumn{2}{|l|}{$\underline{\text { Birds }}$} \\
\hline $\begin{array}{l}\text { Common loon } \\
\text { Whistling swan } \\
\text { Canada goose } \\
\text { Mallard } \\
\text { Blue-winged teal } \\
\text { Wood duck } \\
\text { Turkey vulture } \\
\text { Bobwhite } \\
\text { Ring-necked pheasant } \\
\text { Killdeer } \\
\text { Mourning dove } \\
\text { Screech owl } \\
\text { Downy woodpecker } \\
\text { Common crow } \\
\text { American robin }\end{array}$ & $\begin{array}{l}\text { Gavia immer } \\
\text { Olor columbianus } \\
\text { Brunta canadensis } \\
\text { Anas olatyshynchos } \\
\text { Anas discors } \\
\text { Aix sponsa } \\
\text { Cathartas aura } \\
\text { Colinus virginianus } \\
\text { Phasianus colchicus } \\
\text { Charodrius vociferus } \\
\text { Zenaida macroura } \\
\text { Otus asio } \\
\text { Dendrocopos pubescans } \\
\text { Corvus brachyrhonchos } \\
\text { Turdus migratorius }\end{array}$ \\
\hline
\end{tabular}


3. Direct radiation is measured by thermoluminescent dosimeters (TLDs). The TLDs are collected and analyzed quarterly.

4. Soil samples are collected intermittently and analyzed for radionuclides which may have leached out of the radioactive waste into soil.

5. Vegetation samples are collected intermittently and analyzed for radionuclides that may have been absorbed from the environment and incorporated into plant tissue.

6. Samples of fish and ground squirrels are collected intermittently and analyzed for radionuclides which may have been consumed and accumulated in tissue.

All environmental samples are analyzed for total alpha and beta radioactivity, a method of screening for radionuclides in the disposal trenches which emit either alpha or beta particles. Since tritium emits a very low energy beta particle, tritium cannot be detected by ordinary procedures for evaluating gross beta activity. To measure the concentration of tritium, all of the water samples are distilled and analyzed using a liquid scintillation detector, an instrument that measures radioactive emissions with very low energies and in very low concentrations.

Some samples are analyzed for strontium-90 (a beta-emitter) and gamma-emitting radionuclides such as cesium-137. Strontium- 90 is easily masked by other radionuclides, including those which are naturally-occurring. Selected samples which may contain strontium undergo preliminary chemical separation so that the strontium can be isolated for analysis. Gamma-emitting radionuclides are analyzed in a process called gamma spectroscopy using a high purity germanium detector which enables the identification of radionuclides individually.

The Illinois Department of Nuclear Safety laboratory developed a procedure for analysis of environmental carbon-14. Since carbon-14 occurs naturally in the environment along with the carbon present in vegetation and water, the laboratory performs an analysis for total organic carbon as well as the analysis for carbon- 14 .

The standard unit of measurement for radioactivity has been the curie (Ci). Multiples or fractions of a curie follow standard metric system prefixes. The Illinois Department of Nuclear Safety expresses results of the radioactivity monitoring in terms of picocuries per liter $(\mathrm{pCi} / \mathrm{L})$ for water; femtocuries per cubic meter $\left(\mathrm{fCi} / \mathrm{m}^{3}\right)$ for air; picocuries per gram $(\mathrm{pCi} / \mathrm{g})$ for soil; picocuries per kilogram $(\mathrm{pCi} / \mathrm{kg}$ ) for animals and fish; and nanocuries per liter $(\mathrm{nCi} / \mathrm{L})^{c}$ for tritium in water distilled from vegetation samples. The direct radiation measurements are expressed in milliroentgens per year $(\mathrm{mR} / \mathrm{y})$.

In 1976, tritium (a radioactive form of hydrogen) was discovered in shallow groundwater beneath the 20 -acre site. This was the first evidence of radioactivity leaking from the burial trenches. In 1981 , tritium was discovered in groundwater to the east of the site. This was the first evidence of radioactive material moving off the 20 -acre site. Since then, tritium movement has been traced to the east where it

c. A nanocurie (nCi) is a measure of radioactivity equivalent to 37 nuclear transitions per second. A liter (L) is a measure of volume equal to 1.05 quarts. 
discharges into a small lake (Trout Lake) located about 1000 feet from the site (Figures 2-8 and 2-9). The groundwater carrying the tritium away from the site and Trout Lake are both located within the 170-acre buffer zone that surrounds the site. Trout Lake serves to both dilute and impound the vast majority of tritium moving from the site.

The new, low permeability cap was completed in late summer 1989. The graph of tritium in the Northeast Pathway Wells (Figure 2-10) illustrates the tritium concentrations prior to the completion of the cap and subsequent to it. Prior to installation of the cap, the tritium concentrations averaged about 400 nanocuries per liter $(\mathrm{nCi} / \mathrm{L})$ around the rising trend line. After installation of the cap, the concentrations continued to increase at an average rate of approximately $107 \mathrm{nCi} / \mathrm{L}$ and peaked at 890 $\mathrm{nCi} / \mathrm{L}$ in well No. 575 about the third quarter of 1990 . Subsequently, the concentrations have decreased at a rate of $86 \mathrm{nCi} / \mathrm{L}$ per year. These data suggest that the decrease in concentrations may be due to the effectiveness of the low permeability cap.

Recently, levels of tritium in Trout Lake have averaged between 3 and 5 nanocuries per liter (Table 2-3). This is less than $0.2 \%$ of the Department's limit $(3,000 \mathrm{nCi} / \mathrm{L})$ for discharge beyond the buffer zone. Since February 1989, tritium concentrations in Trout Lake have been decreasing at an average rate of about $0.4 \mathrm{nCi} / \mathrm{L}$ per year; in August 1994 the concentration in Trout Lake was $3.2 \mathrm{nCi} / \mathrm{L}$. Again, this decreasing trend is likely due to the new cap. Trace amounts of tritium may exit the buffer zone by seeping from Trout Lake into adjacent groundwater, flowing over the dam spillway during periods of heavy precipitation, or evaporating into the atmosphere. In each case, the tritium is rapidly dispersed and diluted to levels indistinguishable from natural background. The highest levels of tritium observed beyond the buffer zone have been $2.4 \mathrm{nCi} / \mathrm{L}$ and $0.8 \mathrm{nCi} / \mathrm{L}$ in groundwater and surface water, respectively.

\section{Ground Water}

From 1967 to 1976 , most of the ground water monitoring was conducted on samples from wells installed by the site operator. Figure 2-8 indicates sample locations at the Sheffield site. Only gross alpha and beta analyses were conducted during most of this period. Tritium counting capability was developed in 1974. Generally during this period, only background levels of naturally-occurring radionuclides were measured in the monitoring wells. Several anomalous readings were recorded, but additional analyses were unable to repeat them, possibly due to high levels of naturally occurring dissolved solids in the samples. This problem still exists but is now routinely resolved using gamma spectroscopy. Table 2-3 summarizes tritium concentrations in Trout Lake during the period 1981 to 1994.

The U.S. Geological Survey (USGS) began a hydrogeological study of the Sheffield site in 1976 and installed the wells designated 501 to 524, as indicated in Figure 2-9. Tritium was detected in USGS Well 523 in October of 1976. The presence of tritium was verified upon resampling of the well. Tritium was also detected in USGS Well 507 at about the same time. This was the first evidence of radionuclide migration at Sheffield and indicated a slow migration to the southeast. 


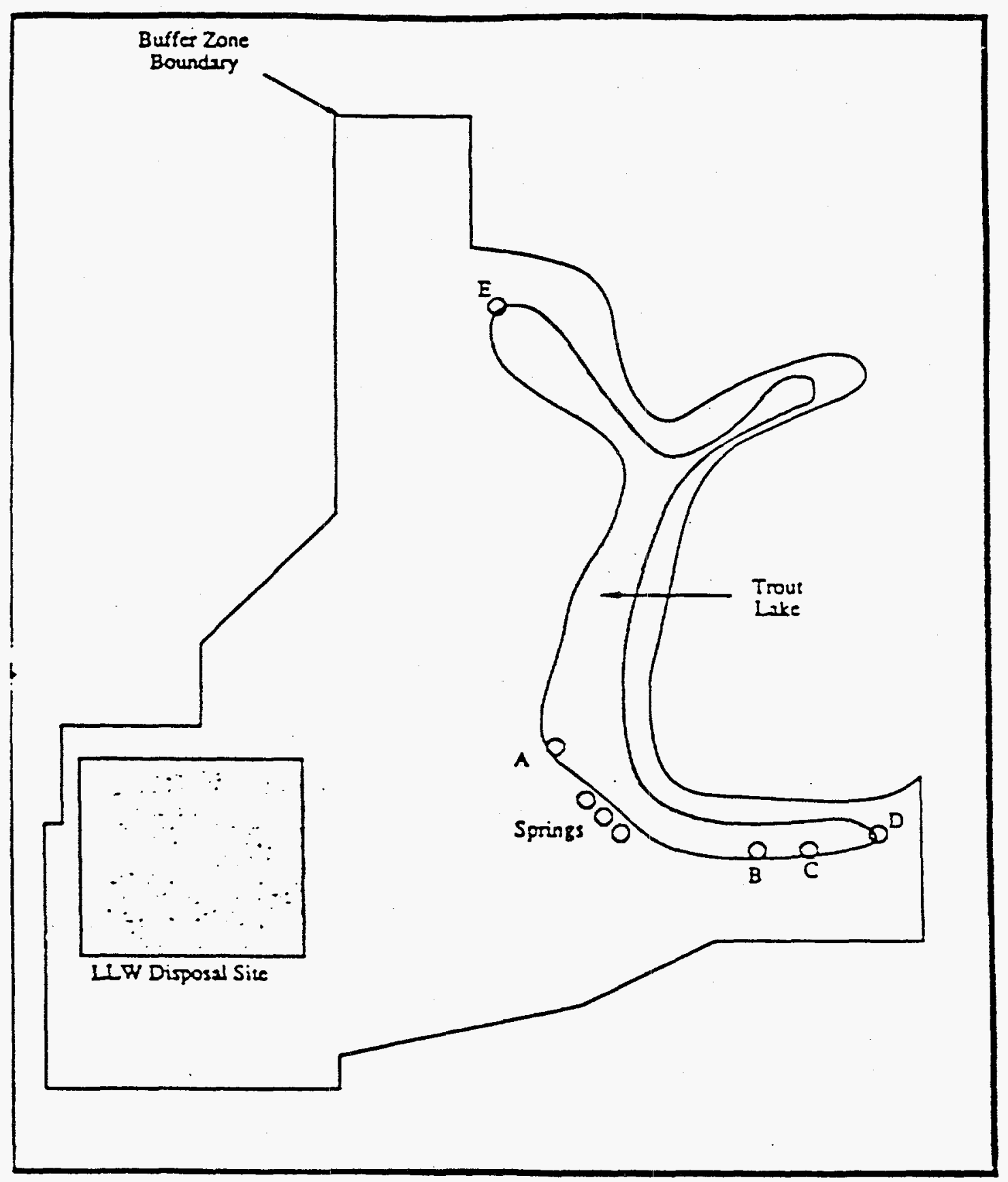

Figure 2-8. Trout Lake sampling locations at the Sheffield site..$^{2-2}$ 
Table 2-3. Tritium concentrations in Trout Lake in nCi/L 1981-1994 at the Sheffield site.

\begin{tabular}{|c|c|c|c|c|c|c|c|c|c|c|c|c|c|c|c|}
\hline & & 1981 & 1982 & 1983 & 1984 & 1985 & 1986 & 1987 & 1988 & 1989 & 1990 & 1991 & 1992 & 1993 & $1994^{*}$ \\
\hline \multirow[t]{4}{*}{ Trout Lake A } & Number & 2 & 7 & 4 & 4 & 3 & 8 & 6 & 18 & 16 & 15 & 13 & 12 & 11 & 6 \\
\hline & Maximum & 0.5 & 1.0 & 0.6 & 0.9 & 1.3 & 1.8 & 2.0 & 6.5 & 6.5 & 5.6 & 4.9 & 4.8 & 3.5 & 3.4 \\
\hline & Minimum & $\angle M D C$ & $\angle M D C$ & $<M D C$ & $<M D C$ & 0.6 & 0.8 & 1.6 & 1.7 & 4.4 & 2.2 & 1.2 & 4.1 & 1.0 & 2.7 \\
\hline & Average & 0.3 & 0.4 & 0.4 & 0.4 & 0.6 & 1.2 & 1.8 & 2.7 & 5.4 & 4.5 & 4.1 & 4.4 & 2.9 & 3.1 \\
\hline \multirow[t]{4}{*}{ Trout Lake B } & Number & 0 & 0 & 0 & 0 & 3 & 4 & 1 & 10 & 13 & 15 & 10 & 11 & 3 & 2 \\
\hline & Maximum & & & & & 1.0 & 1.9 & 1.6 & 4.4 & 9.0 & 5.6 & 5.7 & 5.1 & 4.7 & 3.3 \\
\hline & Minimum & & & & & 0.6 & 0.9 & 1.6 & 1.4 & 5.0 & 3.8 & 3.8 & 4.2 & 3.1 & 3.3 \\
\hline & Average & & & & & 0.8 & 1.3 & 1.6 & 3.0 & 5.9 & 4.8 & 4.4 & 4.6 & 3.7 & 3.3 \\
\hline \multirow[t]{4}{*}{ Trout Lake C } & Number & 0 & 0 & 0 & 0 & 2 & 0 & 0 & 7 & 12 & 14 & 11 & 11 & 4 & 3 \\
\hline & Maximum & & & & & 0.9 & & & 4.5 & 7.6 & 5.4 & 4.9 & 4.8 & 4.8 & 3.6 \\
\hline & Minimum & & & & & $\angle M D C$ & & & 0.9 & 4.8 & 4.0 & 3.2 & 4.1 & 3.0 & 3.1 \\
\hline & Average & & & & & 0.5 & & & 3.3 & 5.6 & 4.8 & 4.1 & 4.4 & 3.7 & 3.3 \\
\hline \multirow[t]{4}{*}{ Trout Lake D } & Number & 0 & 0 & 0 & 0 & 0 & 0 & 0 & 0 & 13 & 21 & 11 & 12 & 11 & 6 \\
\hline & Maximum & & & & & & & & & 5.9 & 5.7 & 7.6 & 5.4 & 5.7 & 3.5 \\
\hline & Minimum & & & & & & & & & 4.7 & 4.1 & 3.8 & 4.1 & 3.1 & 3.2 \\
\hline & Average & & & & & & & & & 5.2 & 4.9 & 4.7 & 4.5 & 3.9 & 3.3 \\
\hline \multirow[t]{4}{*}{ Trout Lake $\mathrm{E}$} & Number & 0 & 0 & 0 & 0 & 0 & 0 & 0 & 0 & 13 & 14 & 11 & 9 & 3 & 1 \\
\hline & Maximum & & & & & & & & & 5.5 & 5.4 & 4.6 & 4.6 & 3.0 & 3.0 \\
\hline & Minimum & & & & & & & & & 4.4 & 3.6 & 3.1 & 3.9 & 2.8 & 3.0 \\
\hline & Average & & & & & & & & & 5.0 & 4.6 & 3.9 & 4.2 & 2.9 & 3.0 \\
\hline
\end{tabular}




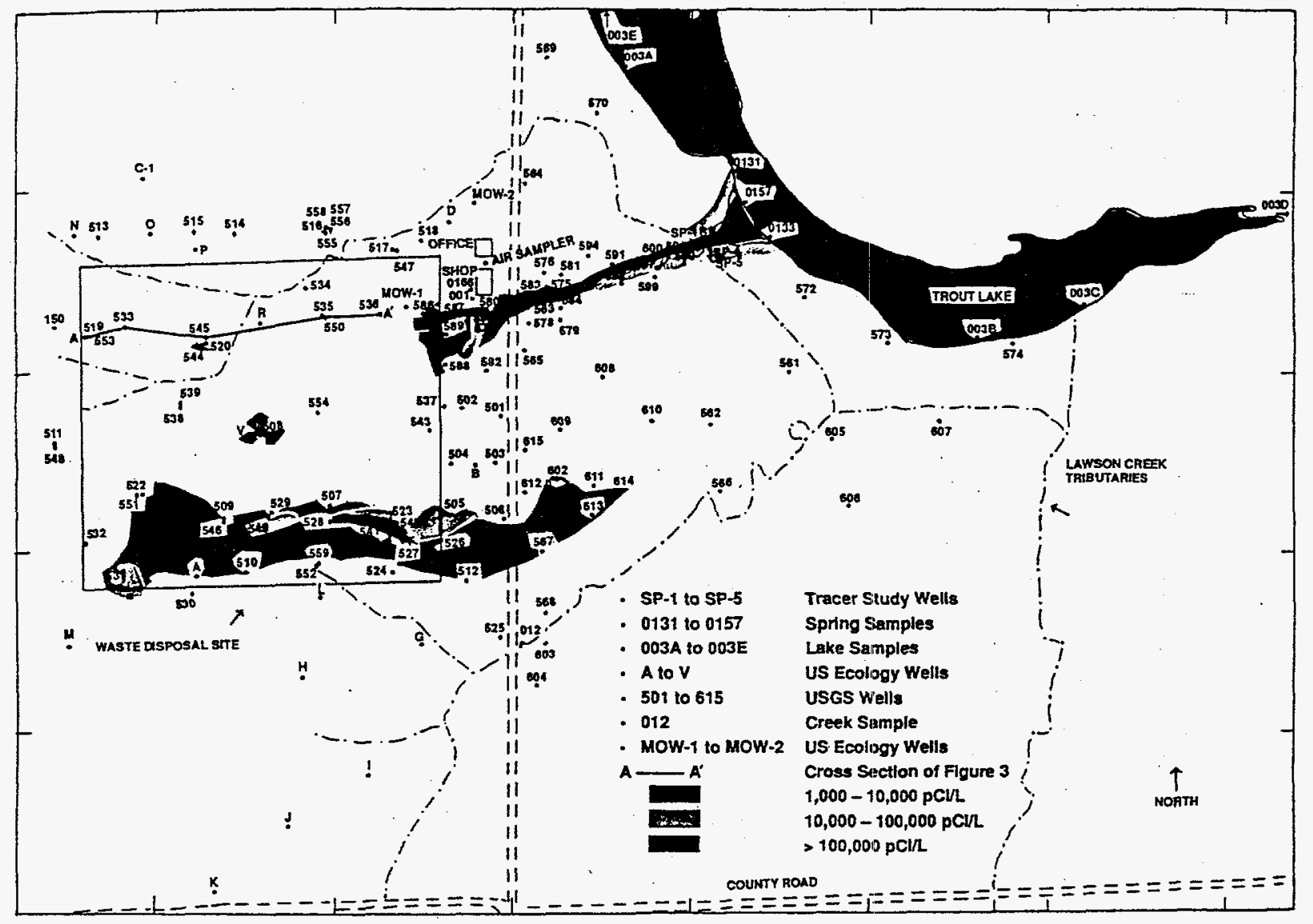

\section{SHEFFIELD}

BASE FROM U.S. GEOLOGICAL SURVEY

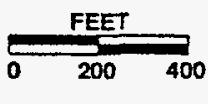

Figure 2-9. Well locations and tritium concentrations (shaded) in water at the Sheffield site. ${ }^{2-2}$

AUGUST 5, 1988

From the summer of 1977 to the fall of 1981 , the objective of the environmental monitoring was to continue to investigate the movement of ground water in the southeast quadrant of the site and to perform general hydrogeologic studies. The USGS installed additional monitoring wells in the series 525 to 559 and the Illinois Department of Nuclear Safety continued to conduct sampling and analysis. In 1977, tritium was found in USGS wells 527 and 528, providing further evidence of tritium movement in the southeasterly direction. On-site. Well 523 continued to exhibit the highest concentration of tritium in this area through the end of 1981. In 1981, a single measurement of $133,000 \mathrm{pCi} / \mathrm{L}$ was obtained. For comparison, the maximum permissible concentration of tritium in water released into unrestricted areas was $3,000,000 \mathrm{pCi} / \mathrm{L}$.

Since the general hydrogeologic studies indicated ground water movement to the north and east, the USGS installed wells 560 to 576 in this area in the summer of 1981. Tritium was found in USGS well 563 in November 1981, which was the first time that tritium had been detected beyond the original site boundary. Based on this finding, USGS Wells 577 to 596 were installed northeast of the property in the summer of 1982 to determine the source, velocity, and extent of the tritium movement. A narrow northeast pathway was found to be about 6 to $12 \mathrm{~m} \mathrm{(20} \mathrm{to} 40 \mathrm{ft}$ ) wide through the sampling and analysis of the new wells. This plume is bounded on the southwest by the original 8 hectare ( 20 acre) site and by Trout Lake on the northeast. About $250 \mathrm{~m}(800 \mathrm{ft})$ separate the site from Trout Lake. 
Since 1982, the focus of the ground water monitoring program has been to monitor tritium concentrations in both the southeast and the northeast pathways, in order to determine whether a potential exists for exposure to the general public. The monitoring of wells 501 to 559 has continued at a lower frequency, because the efforts have been shifted further to the northeast.

In preparation for trench recapping, several of the wells on or near the original site were sealed in 1987. This included on-site well 523, which had exhibited exceptionally high tritium concentrations until it was closed. One of the last 1987 measurements was found to be greater than $1,300,000 \mathrm{pCi} / \mathrm{L}$.

\section{Monitoring of Springs}

The three springs which empty into Trout Lake from the west (Figure 2-9) were found to contain tritium in October 1982. These springs are the end of the northeast pathway. The USGS conducted a tracer dye study in 1984 to determine ground water velocities along the northeast pathway. This study found that the ground water velocity was about $800 \mathrm{~m}(2,500 \mathrm{ft})$ per year downgradient of USGS well 601. This measurement represents the highest ground water velocity in that area; due to the variability in hydrogeologic characteristics, inferences regarding other ground water velocities are difficult to make.

\section{Northeast Pathway Tritium}

The Illinois Department of Nuclear Safety has expended considerable effort toward describing the tritium concentrations in the wells and springs of the northeast pathway (Figures 2-7 through 2-11). Factors which appear to have an interdependent influence on concentrations at a given time in a given well are:

1. Precipitation on the disposal site

2. The condition of the trench caps during precipitation

3. Precipitation in the areas which recharge the pathway wells.

Precipitation variations on the disposal site result in variable amounts of tritium available for transport. A cyclical pattern of tritium concentrations occurs in many of the northeast pathway wells due to a combination of the variables.

USGS wells 577, 580, 583, 563, 575, 592, 597, 600, and 601 (Figure 2-9) are placed along the northeast pathway. Tritium concentrations increased in these wells until reaching peak concentrations above $100,000 \mathrm{pCi} / \mathrm{L}$. Tritium concentration has tended to change over longer periods of time in contrast to the on-site wells. USGS well 528 (near the trenches) exhibits sharp spikes in concentration which are related to single or closely-grouped rainfall events.

\section{Southeast Pathway Tritium}

The USGS installed wells 608 to 615 (Figure 2-9) in May 1983. The purpose of these wells was to determine the path of ground water to the southeast after it crosses the boundary of the disposal site. 


\section{Illinois Department of Nuclear Safety \\ Sheffield LLW Site}

Tritium in Northeast Pathway Wells

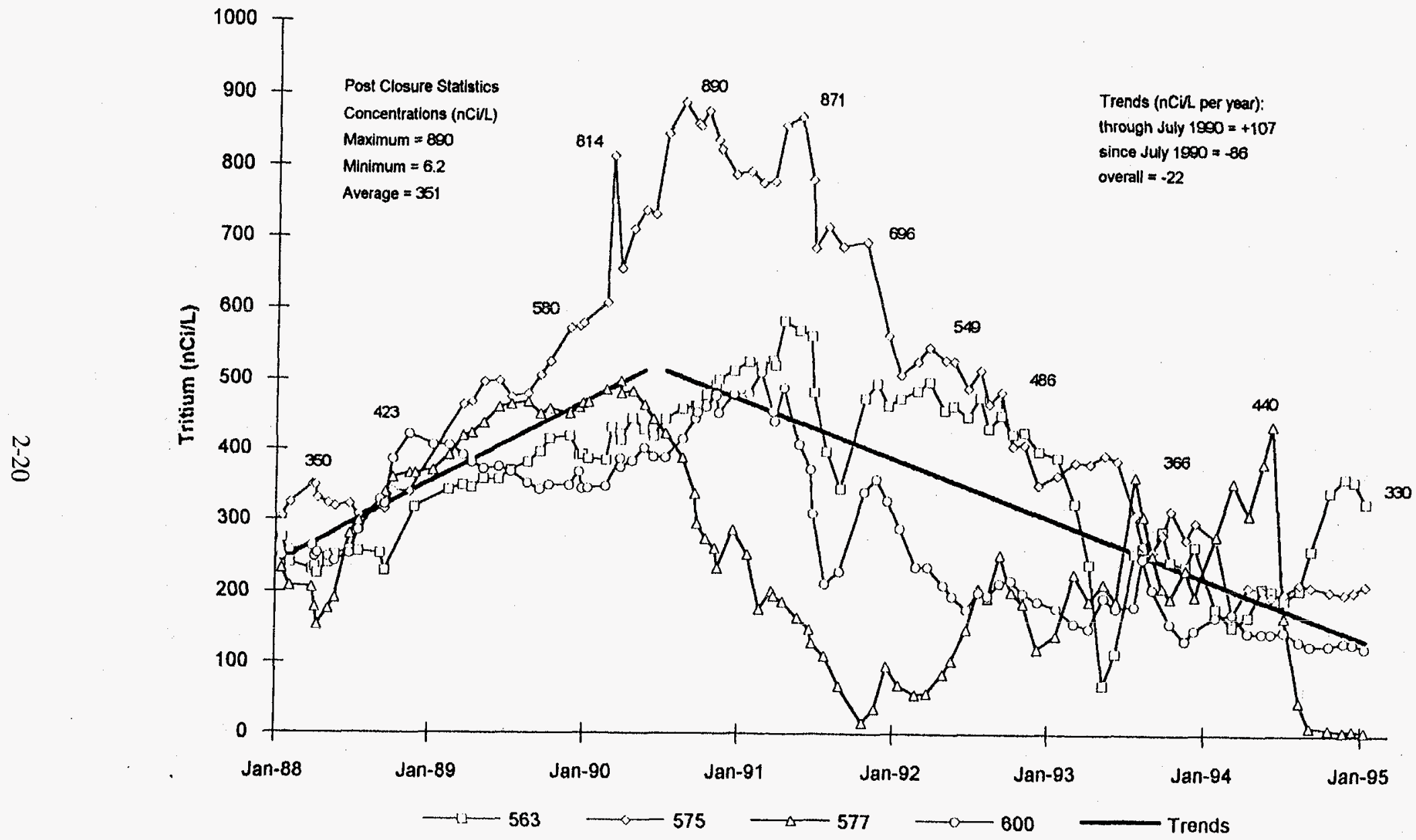

According to the provisions of the Agreed Order of May 1988, the limits for discharge beyond the buffer zone are $3000 \mathrm{nCi} / \mathrm{l}$.

Figure 2-10. Tritium concentrations in northeast pathway wells at the Sheffield site. ${ }^{2-2}$ 

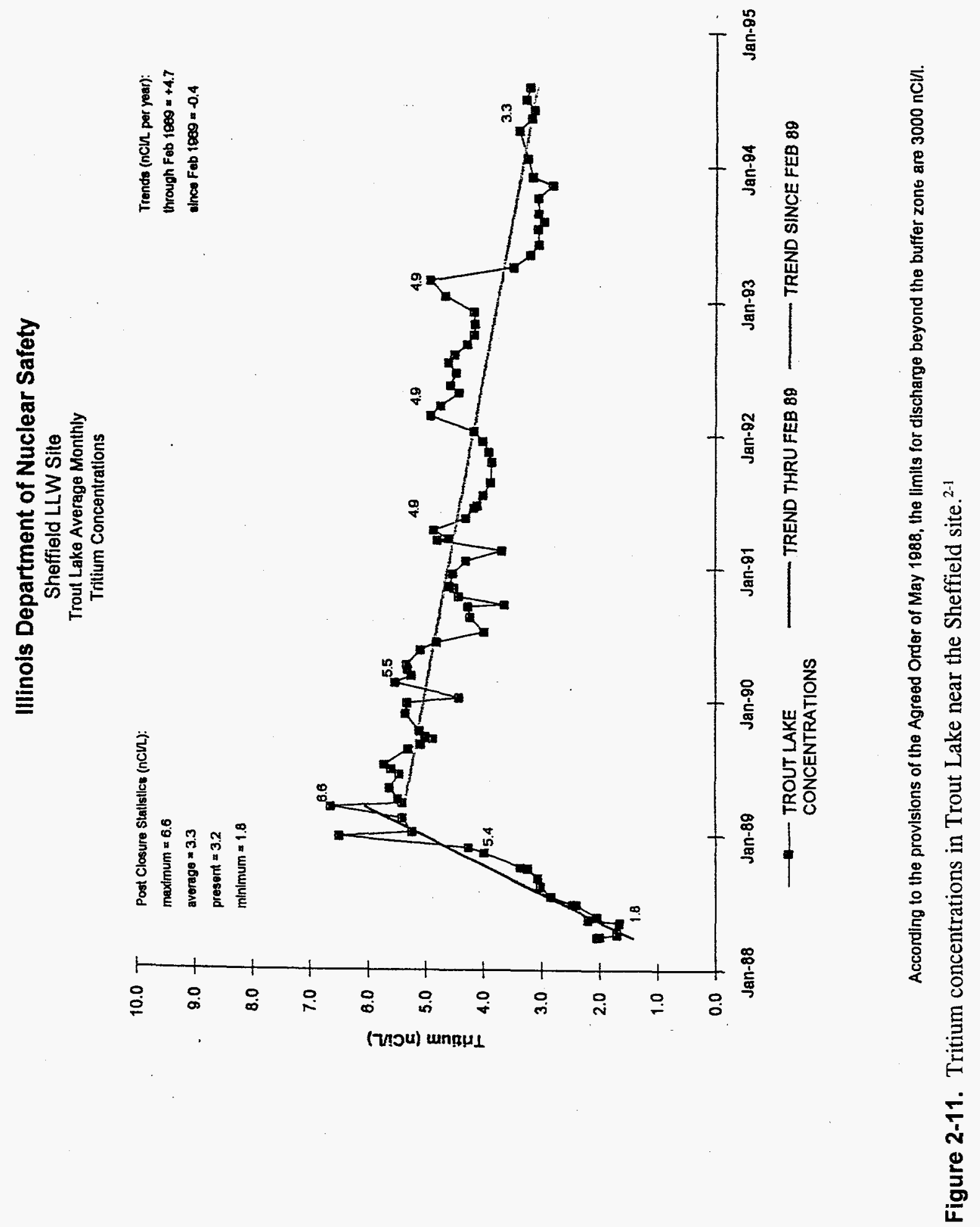
The samples obtained from these wells indicated that the tritium does not continue to move to the southeast but turns toward the northeast. Although the migration rate along this pathway has not been measured directly, it appears to be slower than along the northeast pathway. Data from the wells numbered 603 and 604 indicated little or no tritium. However, samples from wells numbered 602 , 611 , and 613 indicate up to $6,400 \mathrm{pCi} / \mathrm{L}$. Information from these wells generally corroborated the ground water flow information from earlier studies.

\section{Surface Water}

Surface water monitoring consisted of periodic sampling of the intermittent streams around the site, Lawson Creek, and a single location at Trout Lake (Figure 2-9 and 2-12) during the early years of operation. The springs that discharge into Trout Lake have been sampled regularly since October 1982. Samples from as many as five different locations in Trout Lake have been taken on a regular basis. The tritium concentrations at the different sampling locations in Trout Lake appear to depend on the following variables:

1. The flow of water from the springs

2. The runoff from surrounding areas

3. The discharge to the Lawson Creek tributary, if any

4. The presence of ice on the lake.

Evidence of uneven mixing has been observed under some exceptional conditions. The sampling location $E$ on Trout Lake has been lower than the overall mean concentration when ice is on the lake and when discharge occurs from the opposite end. A summary of the tritium results from the Trout Lake sampling is contained in Table 2-3 and shown in Figure 2-11. A summary of the tritium results from the stream and creek sampling is contained in Table 2-4.

Drinking water samples have been taken from off-site locations (Figure 2-12) in the Sheffield area to assure that there has been no impact on local water supplies since the site opened in 1967 . Only naturally occurring radionuclides have been found in samples of these water supplies. No radionuclides attributable to activities from the radioactive waste disposal site were found in any of these water suppllies. Figure 2-12 indicates the locations of the sampling sites.

\section{Air}

Figure 2-9 indicates an air monitoring station located near the northeast quadrant of the site, near Trenches 23 and 24. This sampler has been used to continuously collect particulate samples since February 1977. The filters have been analyzed weekly for gross alpha and beta activity. For the majority of the monitoring periods, the air monitoring results did not indicate any statistically significant increases over natural background. Nuclear weapons testing in 1977 and 1980 and the Chernobyl accident in 1986 were the exceptions when the airborne concentrations of radionuclides were elevated over most of the northern hemisphere due to the release of fission products. The 
Note: Big Bend Conservation Area is 25 miles north-northwest of Sheffleld and not shown on this map

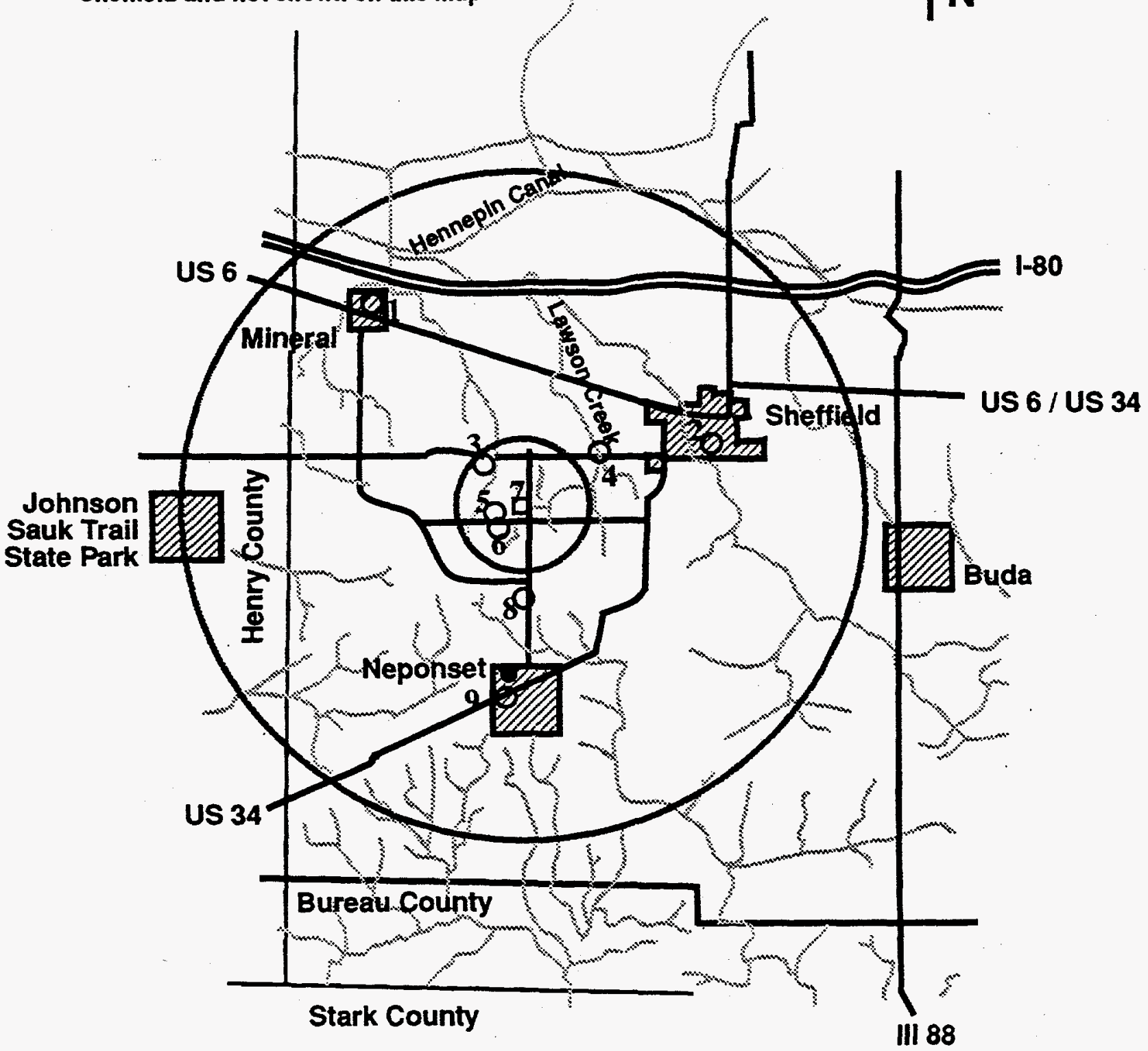

1,5 Mile Circles

Streams and Lakes

\section{Sampling Locations}

1- Mineral Public Water System

2- Sheffleld Publlc Water System

3- Lorenson Farm

4- Bennett Farm

5- Moore Farm
6- Pencock HIII

7- US Ecology Lunchroom Tap

8- Blake Farm

9- Neponset Publlc Water System

Figure 2-12. Environmental sampling around the Sheffield site..$^{2-2}$ 
Table 2-4. Tritium concentrations in streams and creeks in nCi/L 1981-1994 at the Sheffield site.

\begin{tabular}{|c|c|c|c|c|c|c|c|c|c|c|c|c|c|c|c|}
\hline & & 1981 & 1982 & 1983 & 1984 & 1985 & 1986 & 1987 & 1988 & 1989 & 1990 & 1991 & 1992 & 1993 & $1994^{*}$ \\
\hline \multirow[t]{4}{*}{ Coal Creek } & Number & 0 & 0 & 2 & 0 & 0 & 3 & 3 & 4 & 5 & 4 & 7 & 12 & 8 & 1 \\
\hline & Maximum & & & $\angle M D C$ & & & 0.5 & $<M D C$ & $\angle M D C$ & $\angle M D C$ & $<M D C$ & $\angle M D C$ & $\angle M D C$ & $\angle M D C$ & $<M D C$ \\
\hline & Minimum & & & $\angle M D C$ & & & $\angle M D C$ & $\angle M D C$ & $<M D C$ & $\angle M D C$ & $\angle M D C$ & $<M D C$ & $<M D C$ & $<M D C$ & $\angle M D C$ \\
\hline & Average & & & $<M D C$ & & & $<M D C$ & $<M D C$ & $<M D C$ & $\angle M D C$ & $\angle M D C$ & $\angle M D C$ & $\angle M D C$ & $<M D C$ & $\angle M D C$ \\
\hline \multirow[t]{4}{*}{ Lawson Creek } & Number & 0 & 0 & 3 & 2 & 3 & 4 & 3 & 5 & 14 & 18 & 11 & 12 & 11 & 7 \\
\hline & Maximum & & & $<M D C$ & $<M D C$ & $\angle M D C$ & 0.5 & 0.3 & 1.2 & $<M D C$ & 0.5 & 0.7 & 0.4 & 0.5 & 0.4 \\
\hline & Minimum & & & $<M D C$ & $\angle M D C$ & $\angle M D C$ & $<M D C$ & $\angle M D C$ & $\angle M D C$ & $<M D C$ & $\angle M D C$ & $\angle M D C$ & $<M D C$ & 0.2 & $<M D C$ \\
\hline & Average & & & $<M D C$ & $\angle M D C$ & $\angle M D C$ & $<M D C$ & $<M D C$ & 0.4 & $\angle M D C$ & 0.2 & 0.3 & 0.2 & 0.3 & $<M D C$ \\
\hline \multirow{3}{*}{$\begin{array}{l}\text { Stream Northwest } \\
\text { of Site }\end{array}$} & Number & 3 & 4 & 5 & 3 & 3 & 4 & 3 & 3 & 5 & 4 & 9 & 12 & 8 & 1 \\
\hline & Maximum & 0.4 & 0.6 & $\angle M D C$ & $\angle M D C$ & $\angle M D C$ & 0.4 & $<M D C$ & $<M D C$ & $\angle M D C$ & $\angle M D C$ & $<M D C$ & 0.2 & $<M D C$ & $\angle M D C$ \\
\hline & Minimum & $<M D C$ & $<M D C$ & $\angle M D C$ & $\angle M D C$ & $\angle M D C$ & $\angle M D C$ & $<M D C$ & $<M D C$ & $<M D C$ & $\angle M D C$ & $<M D C$ & $\angle M D C$ & $\angle M D C$ & $\angle M D C$ \\
\hline & Average & 0.3 & 0.3 & $\angle M D C$ & $\angle M D C$ & $\angle M D C$ & 0.2 & $\angle M D C$ & $<M D C$ & $\angle M D C$ & $\angle M D C$ & $<M D C$ & $\angle M D C$ & $\angle M D C$ & $<M D C$ \\
\hline \multirow{4}{*}{$\begin{array}{l}\text { Stream South } \\
\text { of Site }\end{array}$} & Number & 3 & 7 & 7 & 3 & 1 & 4 & 3 & 3 & 5 & 5 & 9 & 11 & 4 & 6 \\
\hline & Maximum & 0.4 & 0.7 & $<M D C$ & $\angle M D C$ & $<M D C$ & 0.6 & $<M D C$ & $<M D C$ & $\angle M D C$ & $\angle M D C$ & $<M D C$ & $<M D C$ & $<M D C$ & 0.3 \\
\hline & Minimum & $\angle M D C$ & 0.3 & $\angle M D C$ & $<M D C$ & $\angle M D C$ & $<M D C$ & $<M D C$ & $\angle M D C$ & $\angle M D C$ & $\angle M D C$ & $\angle M D C$ & $<M D C$ & $\angle M D C$ & $\angle M D C$ \\
\hline & Average & 0.2 & 0.5 & $\angle M D C$ & $\angle M D C$ & $\angle M D C$ & $<M D C$ & $\angle M O C$ & $\angle M D C$ & $\angle M D C$ & $\angle M D C$ & $\angle M D C$ & $\angle M D C$ & $\angle M D C$ & $\angle M D C$ \\
\hline
\end{tabular}


sampling results do not indicate any airborne releases from the Sheffield site. Air sampling results are summarized in Table 2-5.

\section{Direct Radiation}

Thermoluminescent dosimeters (TLDs) were used for direct radiation measurements. The number of monitoring sites has varied over the years as a result of occasional badge losses, malfunctioning of equipment, and changes in the scope of the program. The dosimeters that were closest to the site entrance were exposed to the incoming shipments of radioactive wastes. Elevated TLD readings resulted from this placement. During 1976, the highest on-site levels of direct radiation were $234 \mathrm{mRem} / \mathrm{y}$. According to the waste receipt and burial records, 1976 was a peak period for volume and curie quantity of radioactive waste in storage above ground. Since the cessation of waste burial at the site, all readings have been typical of natural background in northern Illinois, about 65 $\mathrm{mRem} / \mathrm{y}$. A summary of the cumulative total exposures measured since 1971 is contained in Table 2-6.

\section{Soil}

Soil samples have been taken to determine whether surface contamination exists from the unloading of shipments and from burial operations. A sample taken and analyzed in 1976 indicated no contamination was present. Only potassium-40 and radium-226, naturally occurring radionuclides, were reported in the sample. Cesium-137 was found in two samples taken near USGS wells 507 and 512 in 1977. Duplication of samples did not verify the results, which thus remain anomalies. Wells 507 and 512 are located in the southeast quadrant and just east of the southeast quadrant, respectively.

\section{Biota}

Vegetation samples have been taken periodically since the site opened. These samples were taken to determine whether any bioaccumulation of radionuclides from the Sheffield site has occurred. The results demonstrate that no detectable release from the Sheffield site has occurred. Only radionuclides contributed from radioactive fallout (cesium-137, niobium-95, zirconium-95, ruthenium-103, strontium89 , strontium-90) and naturally occurring radioactive materials were identified.

Tritium concentrations found in vegetation appear to relect the concentrations of tritium in the ground water near a plant's root system. When the origin of the tritium is ground water, the concentrations found in the deeper rooted plants (such as alfalfa) are usually higher than those detected in more shallow rooted grasses. Tritium conentrations have ranged from 1,300 to $16,000 \mathrm{pCi} / \mathrm{L}$ in grass samples, from 200 to $35,800 \mathrm{pCi} / \mathrm{L}$ in clover, and from 6,300 to $89,000 \mathrm{pCi} / \mathrm{L}$ in alfalfa. Tritium levels have been measured at $31,900 \mathrm{pCi} / \mathrm{L}$ in brome grass and at $10,400 \mathrm{pCi} / \mathrm{L}$ in tree leaves. The higher concentrations were found on the tops of the trench caps.

Fish samples have been taken to determine whether any bioaccumulation of radioactive material has occurred in aquatic life in Trout Lake. The results of samples collected in 1977 and 1982 indicated that only naturally occurring radionuclides were found at levels greater than the minimum detectable concentration (MDC). Improvements in laboratory analytical techniques resulted in a more sensitive MDC in 1988. Strontium-90 concentrations from $10-17 \mathrm{pCi} / \mathrm{kg}$ were found in samples collected in 1988. The strontium levels in fish will generally be 20 times higher than the strontium level in the 
Table 2-5. Air sampling results in $\mathrm{fCi} / \mathrm{m}^{3} 1977-1994$ at the Sheffield site.

\begin{tabular}{|c|c|c|c|c|c|c|c|c|c|c|c|c|c|c|}
\hline & & 1977 & 1978 & 1979 & 1980 & 1981 & 1982 & 1983 & 1984 & 1985 & 1986 & 1987 & 1988 & 1989 \\
\hline \multirow[t]{4}{*}{ Gross Alpha } & Number & 37 & 36 & 35 & 19 & 11 & 8 & 3 & 18 & 46 & 51 & 48 & 53 & 55 \\
\hline & Maximum & 12 & 3 & 12 & $200^{\prime}$ & 6 & 7 & 4 & 11 & 18 & 16 & 10 & 21 & 21 \\
\hline & Minimum & $<M D C$ & $\angle M D C$ & $<M D C$ & 0 & 1 & 0 & 0 & 2 & 1 & 1 & 1 & $<M D C$ & $<M D C$ \\
\hline & Average & 4 & 0 & 1 & 12 & 2 & 2 & 2 & 7 & 5 & 6 & 3 & 5 & 5 \\
\hline \multirow[t]{4}{*}{ Gross Beta } & Number & 37 & 36 & 35 & 19 & 11 & 8 & 3 & 18 & 46 & 51 & 47 & 53 & 55 \\
\hline & Maximum & $455^{\prime}$ & 110 & 20 & $2800^{\prime}$ & $335^{1}$ & 100 & 43 & 31 & 73 & $420^{\prime}$ & 41 & 44 & 110 \\
\hline & Minimum & 21 & 10 & 2 & 3 & 6 & 7 & 2 & 12 & 10 & 13 & 9 & 12 & 12 \\
\hline & Average & 100 & 38 & 10 & 180 & 108 & 31 & 19 & 18 & 22 & 49 & 24 & 22 & 28 \\
\hline
\end{tabular}

\begin{tabular}{llccccc}
\hline & & 1990 & 1991 & 1992 & 1993 & $1994^{2}$ \\
\cline { 3 - 6 } & & & & & & \\
\multirow{5}{*}{ Gross Alpha } & Number & 50 & 45 & 50 & 49 & 34 \\
& Maximum & 12 & 4 & 3 & 4 & 2 \\
& Minimum & $<M D C$ & $<M D C$ & $<M D C$ & $<M D C$ & $<M D C$ \\
& Average & 3 & 1 & 1 & 0 & 0 \\
& & & & & & \\
& Number & 51 & 47 & 50 & 49 & 34 \\
& Maximum & 71 & 34 & 36 & 42 & 42 \\
& Minimum & 12 & 7 & 4 & 6 & 5 \\
& Average & 27 & 18 & 14 & 17 & 15 \\
\hline
\end{tabular}

1 - Elevated concentrations coincide with general northern hemisphere conditions due to atmospheric releases of fission products, including nuclear weapons testing in 1977 and 1980 and the Chernobyl accident in 1986.

2 - Data thru August 1994. 
Table 2-6. Direct radiation (TLD) results in mR/y 1977-1994 at the Sheffield site.

\begin{tabular}{|c|c|c|c|c|c|c|c|c|c|c|c|c|c|c|c|c|}
\hline 10 & Location & 1971 & 1972 & 1973 & 1974 & 1975 & 1976 & 1977 & 1978 & 1979 & 1980 & 1983 & 1984 & 1987 & 1988 & $1989^{\prime}$ \\
\hline 1 & Air Sampler Housing & 124 & 86 & 114 & 99 & 100 & 115 & 128 & 117 & 80 & 50 & 62 & 95 & 121 & 53 & 43 \\
\hline 2 & Above Change Romm Door & & 335 & 194 & 134 & 469 & 470 & 161 & 186 & 69 & 41 & 58 & 44 & & 42 & 30 \\
\hline 3 & South Fence Near West End & & 198 & 138 & 106 & 188 & 163 & 93 & 102 & 47 & 62 & 69 & 44 & & 54 & 49 \\
\hline 4 & Near White Fence by Office & & 239 & 140 & 99 & 121 & 186 & 112 & 124 & & & 62 & 43 & 54 & 56 & 47 \\
\hline 6 & Northeast Corner of Fence & & & & & & & 200 & 146 & & 58 & 66 & 47 & 65 & 51 & 42 \\
\hline 7 & Northwest Corner of Fence & & & & & & & 189 & 179 & & 75 & 80 & 77 & 53 & 57 & 48 \\
\hline 8 & Southwest Corner of Fence & & & & & & & 216 & 153 & & 57 & 73 & 75 & 51 & 51 & 42 \\
\hline \multirow[t]{2}{*}{9} & Southeast Corner of Fence & & & & & & & 190 & 179 & & 38 & 73 & 62 & 44 & 46 & 28 \\
\hline & On-Site Average & 124 & 215 & 147 & 110 & 220 & 234 & 161 & 148 & 65 & 54 & 68 & 61 & 65 & 51 & 41 \\
\hline 5 & In Șheffield & & & & & & & 64 & 72 & 48 & 50 & 51 & 43 & & 54 & 45 \\
\hline 10 & 1 Mile North of Site & & & & & & & 68 & 84 & & 61 & 69 & 64 & & & \\
\hline 11 & 1.5 Miles East of Site & & & & & & & 60 & 58 & & 57 & 47 & 68 & & & \\
\hline 12 & 1 Mile South of Site & & & & & & & 75 & 84 & & 68 & 69 & 46 & & & \\
\hline 13 & 1.5 Miles West of Site & & & & & & & 79 & 95 & & & 66 & 60 & & & \\
\hline 14 & Big Bend Conservation Area & & & & & & & & & & & 100 & & & & \\
\hline . & Off-Site Average & & & & & & & 69 & 79 & 48 & 59 & 67 & 56 & & 54 & 45 \\
\hline
\end{tabular}

N

\begin{tabular}{llcccccc}
\hline \multicolumn{1}{c}{ Location } & $1989^{2}$ & 1990 & 1991 & 1992 & 1993 & $1994^{3}$ \\
\hline 1 Nothwest Corner of Fence & 61 & 61 & 57 & 55 & 51 & 49 \\
2 & Southeast Corner of Fence & 54 & 50 & 47 & 47 & 45 & 43 \\
3 & Middle Of Fence South Side & 62 & 58 & 54 & 52 & 50 & 51 \\
4 & Southwest Corner of Fence & 58 & 61 & 59 & 59 & 56 & 54 \\
5 & Middle of Fence West Side & 66 & 57 & 59 & 58 & 53 & 57 \\
6 & On Fence at Well C-150 & 66 & 64 & 62 & 61 & 58 & 56 \\
7 Middle of Fence North Side & 63 & 60 & 59 & 55 & 50 & 51 \\
8 & Middle of Fence East Side & 60 & 56 & 55 & 49 & 46 & 46 \\
9 & Air Sampler Housing & 40 & 40 & 43 & 42 & 40 & 39 \\
10 & Adjacent to Well C-434 & 57 & 62 & 61 & 58 & 53 & 55 \\
11 Southwest Corner of Buffer Zone Fence & 64 & 57 & 54 & 52 & 47 & 48 \\
12 Buffer Zone Fence at End of Lake Road & 62 & 54 & 54 & 54 & 50 & 51 \\
13 Buffer Zone Fence at NW Corner of Lake & 60 & 58 & 55 & 54 & 51 & 54 \\
\hline
\end{tabular}


body of water from which the fish was obtained, especially in a freshwater aquatic environment. For this reason, strontium in fish is a sensitive indicator and strontium is seldom routinely measured in water. Strontium that has been detected in bottom sediment samples in many control areas of Illinois is attributed to global fallout from nuclear weapons testing.

Burrowing animals have been observed occasionally in the vicinity of the trenches and could transport contamination to the surface of the ground if they burrowed through contaminated soil. Two ground squirrels caught in 1984 in the southwest corner of the site were analyzed at Argonne National Laboratory using gamma spectroscopy. Only naturally occurring potassium- 40 was reported.

\section{SUMMARY}

The Sheffield LLW site operated from 1966 until 1978. It has been closed in accordance with the Agreed Order of 1988 which specifies the actions required to safely close the site and assure it continuing safety in the future.

Environmental monitoring of the Sheffield site started in 1967. No radioactive material above natural background was found in any of the monitoring wells until 1976. In 1976, tritium was detected migrating in a narrow pathway extending to the northeast and terminating in Trout Lake. The quantities of tritium migrating remain below the applicable maximum permissible concentration set in the Agreed Order of 1988 . The tritium concentrations in the public and private drinking water supplies remain at background levels. By 1988, the buffer zone was extended to include Trout Lake.

The new, low permeability cap was completed in late summer 1989. The graph of tritium in the Northeast Pathway Wells demonstrates the tritium concentrations prior to the completion of the cap and subsequent to it. Prior to installation of the cap, the tritium concentrations averaged about 400 nanocuries per liter $(\mathrm{nCi} / \mathrm{L})$ around the rising trend line. After installation of the cap, the concentrations continued to increase at an average rate of approximately $107 \mathrm{nCi} / \mathrm{L}$ and peaked at 890 $\mathrm{nCi} / \mathrm{L}$ in well No. 575 about the third quarter of 1990 . Subsequently, the concentrations have decreased at a rate of $86 \mathrm{nCi} / \mathrm{L}$ per year. These data suggest that the decrease in concentrations may be due to the effectiveness of the low permeability cap.

Only background radioactivity has been found from the air sampling data. Potassium-40 and radium-226, naturally occurring radionuclides, have been found in the soil samples. Radionuclides from fallout and tritium from the trenches have been detected in vegetation samples. The fish samples have contained strontium- 90 from fallout and naturally occurring radionuclides. Only naturally occurring potassium-40 was found in squirrels.

Direct radiation measurements indicate that although the direct radiation levels were elevated during the period that radioactive waste was temporarily stored above ground at the site, direct radiation levels returned to background after the waste was placed in the trenches and covered.

Data collected through 1994 indicate that the closure activities specified in the Agreed Order are functioning as designed. Levels of tritium in both ground and surface water are decreasing; residual contamination is mostly contained within the buffer zone and only minute quantities of radioactive material from the site are detected in ground and surface water beyond the buffer zone. ${ }^{2-1}$ Results of 
sampling and analysis have not detected any off-site exposures attributable to the Sheffield low-level radioactive waste facility. No known exposure to nearby residents has occurred. ${ }^{2-1}$ 


\section{REFERENCES}

2-1. D. D. Ed, "Sheffield Low-Level Radioactive Waste Disposal Site: A Brief Synopsis, Illinois Department of Nuclear Safety," December 12, 1992.

2-2. Illinois Department of Nuclear Safety, Environmental Monitoring Report Sheffield Low-Level Radioactive Waste Disposal Site 1967-1988, 1991.

2-3. Nuclear Engineering Company, Inc., Environmental Report for the Sheffield Low-Level Radioactive Waste Disposal Facility Near Sheffield, Illinois, 1979.

2-4. K. Dragonette, et al., 1979.

2-5. MacKenzie, et al., 1985.

2-6. D. D. Ed, "Sheffield Low-Level Radioactive Waste Disposal Site: A Brief Synopsis, Illinois Department of Nuclear Safety," November 15, 1994.

2-7. Richard W. Healy, Results of Some Geohydrologic Studies at the Low-Level Radioactive Waste Repository Site Near Sheffield, Illinois, In: Safe Disposal of Radionuclides in Low-Level Radioactive Waste Repository Sites, Low-Level Radioactive Waste Disposal Workshop, U.S. Geological Survey, July 11-16, 1987, Big Bear Lake, California, U.S. Geological Survey Circular 1036, pp. 13-16, 1987.

2-8. Foster, et al., Water Resources Investigations Report No. 83-4125, 1984. 


\title{
CHAPTER 3
}

\section{Environmental Summary of the Maxey Flats, Kentucky Low-Level Radioactive Waste Disposal Site}

\author{
INTRODUCTION
}

\section{Background}

The Maxey Flats site has been owned by the State of Kentucky since 1963 and was leased by NECo in that year. The site was used for radioactive waste disposal from May 1963 until December 1977. The Cabinet Health Services (Cabinet for Human Resources) issued an order closing the site to the receipt of commercial waste in December of 1977. In May 1978, the Commonwealth purchased the site from U.S. Ecology (NECO); in addition, the Commonwealth indemnified U.S. Ecology via this agreement.

Kentucky is an Agreement State with licensing authority delegated from the U.S. Nuclear Regulatory Commission (NRC). The Kentucky Natural Resources and Environmental Protection Cabinet is the licensee, while the Cabinet for Health Services (Cabinet for Human Resources) is the agency responsible for the licensing of material in Kentucky.

In 1986, the U.S. Environmental Protection Agency (EPA) placed the Maxey Flats site on its National Priorities List of hazardous sites, based on a Hazard Ranking System score of 31.7. The hazard ranking is the method by which the EPA uses site investigation data in a mathematical formula to rate the magnitude of hazards presented by a particular site. If the hazard ranking is 28.5 or greater, a site is placed on the National Priorities List, making it eligible for cleanup under the Comprehensive Environmental Response, Compensation and Liability Act (CERCLA, commonly referred to as the Superfund law) and the Superfund Amendments and Reauthorization Act (SARA). CERCLA is intended to protect public health and the environment from uncontrolled releases of hazardous substances into the environment. Whenever possible, the tax money spent on cleanup of a designated site is recovered from potentially responsible parties. Over 832 organizations shipped LLW to the Maxey Flats site. The federal government, cooperatively with the Commonwealth of Kentucky, has the CERCLA oversight lead for conducting additional work at the site. ${ }^{3-1}$

\section{Location}

The Maxey Flats commercial low-level radioactive waste disposal facility is located on 102 hectares (252 acres) in Fleming County, Kentucky (Figure 3-1). 


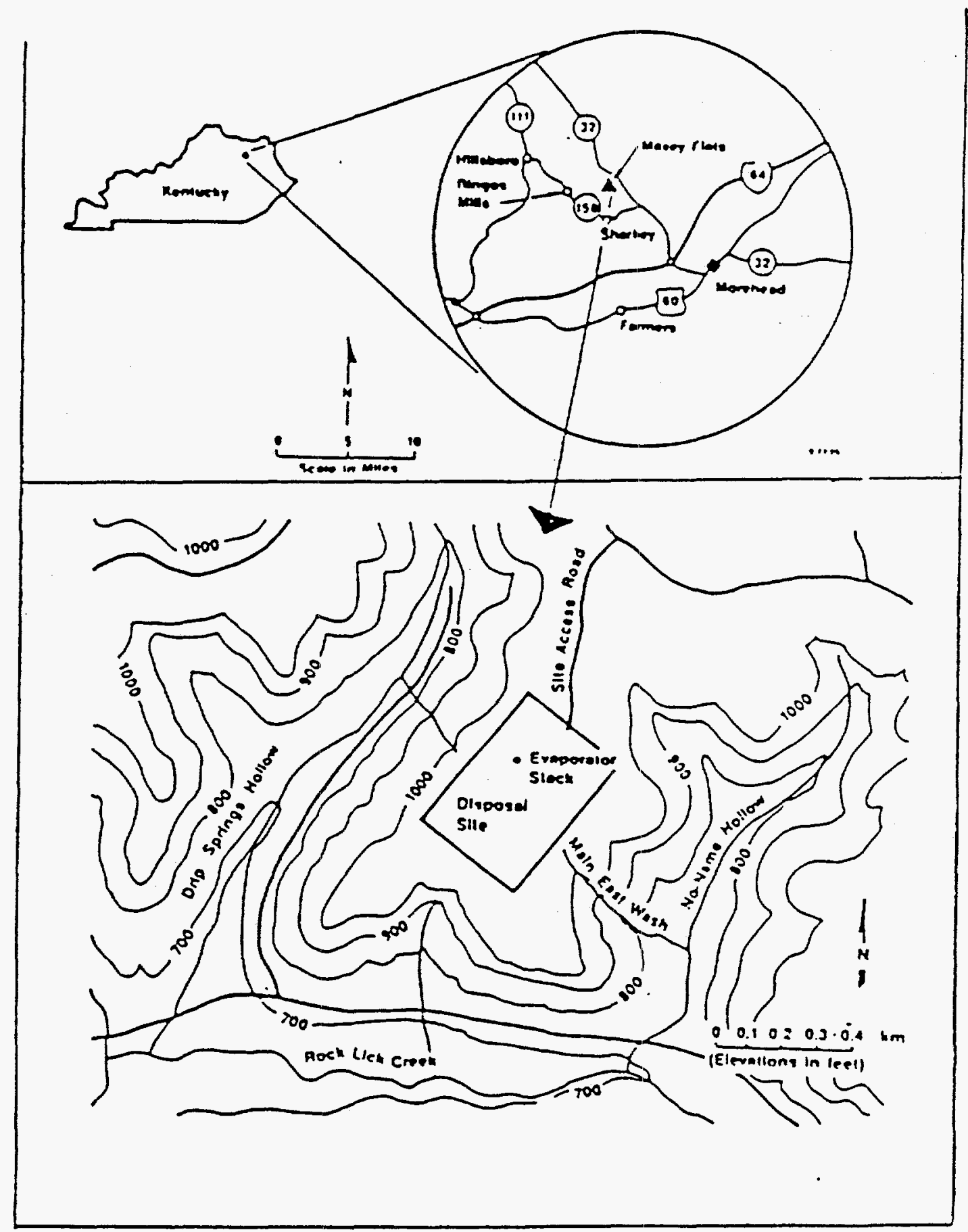

Figure 3-1. Location of Maxey Flats site.

\section{Facility}

The designated restricted area (Figure 3-2), where entry is controlled for the purpose of radiation protection, is 17 hectares ( 42 acres). Wastes were buried (Figure 3-3) in 52 trenches of varied geometry, a number of wells and several special pits. Most of the wastes were solids and were buried in rectangular trenches about $8 \mathrm{~m}(25 \mathrm{ft})$ deep. The sides of the trenches were essentially vertical, 


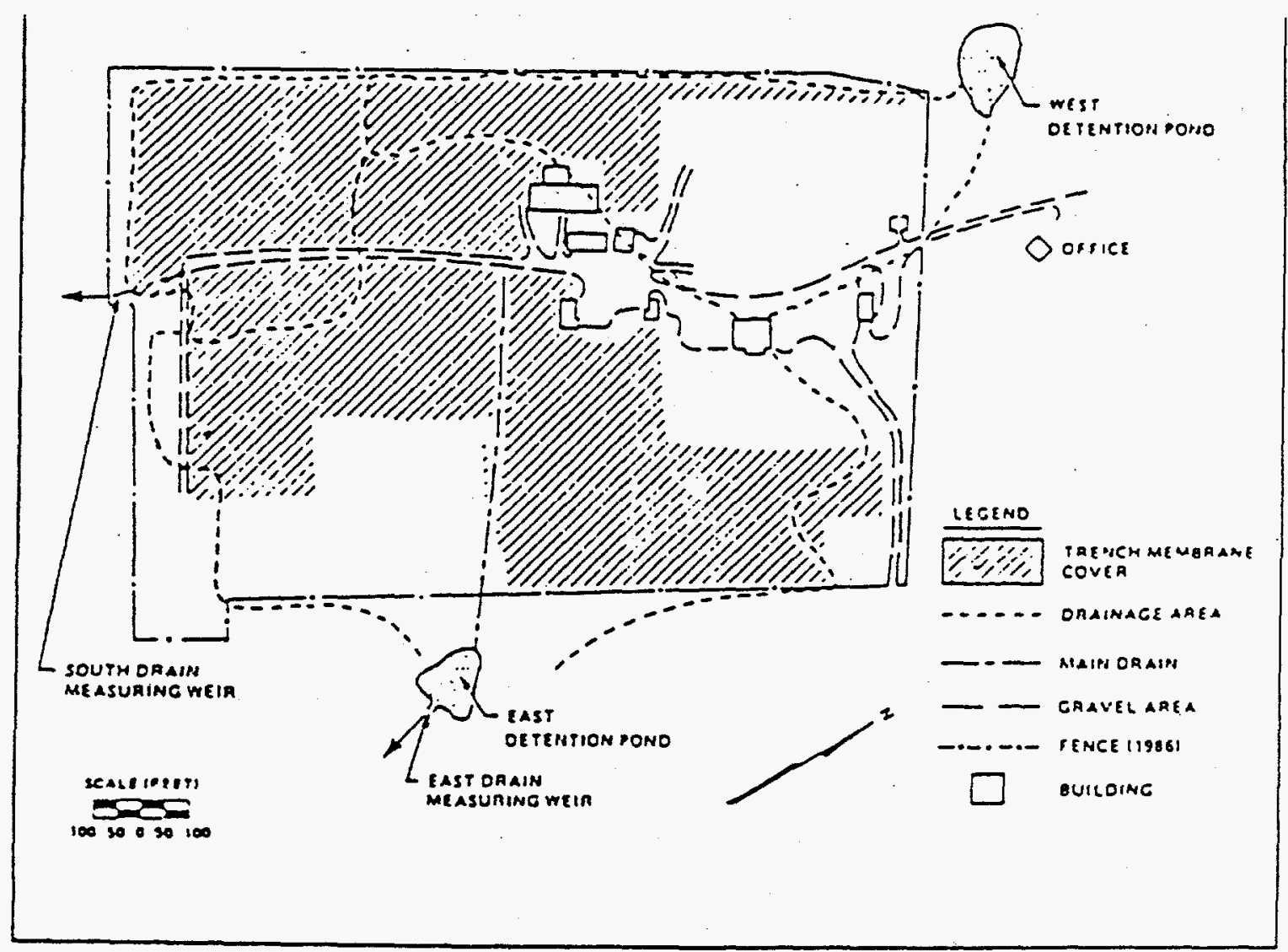

Figure 3-2. General map of the restricted area at the Maxey Flats site.

and adjacent trenches were separated by approximately 3 to $6 \mathrm{~m}(10-20 \mathrm{ft})$ of undisturbed soil and rock. The trenches are separated by about 1.5 to $2 \mathrm{~m}(5-10 \mathrm{ft})$ of shale containing several thin (less than a meter thick) sandstone beds

Most of the wastes were received in steel drums. Other packages included concrete and steel tanks, concrete vaults, and wooden and cardboard boxes. The materials included animal tissue, paper, cardboard, wood, plastics, organic chemicals, clothing, protective apparel, laboratory glassware, obsolete equipment, duct work, radiopharmaceuticals, plastic tubing, and rubble. Other materials included solidified liquids, shielding, filters, ion-exchange resins, activated metals, and evaporator sludges.

To minimize exposure to site workers, the waste containers were placed in the trench bottom in a random manner. The waste was covered with soil on a regular basis to limit possible direct radiation exposure from the trench. No special attempt was made to fill voids between the waste containers with backfill soil.

When filled, the trenches were covered with approximately 1 to $3 \mathrm{~m}$ ( 3 to $10 \mathrm{ft}$ ) of compacted clay and crushed shale.

Trenches 45-51 were filled after the site was closed to the receipt of commercial waste and were used for the disposal of wastes resulting from the site water management program and rubble from the dismantling of surplus facilities and equipment. Most of the trenches were unlined, with dimensions of 
the trenches ranging from 3 to $200 \mathrm{~m}$ ( 15 to $670 \mathrm{ft}$ ) long, 3 to $20 \mathrm{~m}$ (10 to $70 \mathrm{ft}$ ) wide and 3 to $10 \mathrm{~m}$ (10 to $35 \mathrm{ft}$ ) deep. The burial media consisted predominately of a poorly fissile shale interbedded with

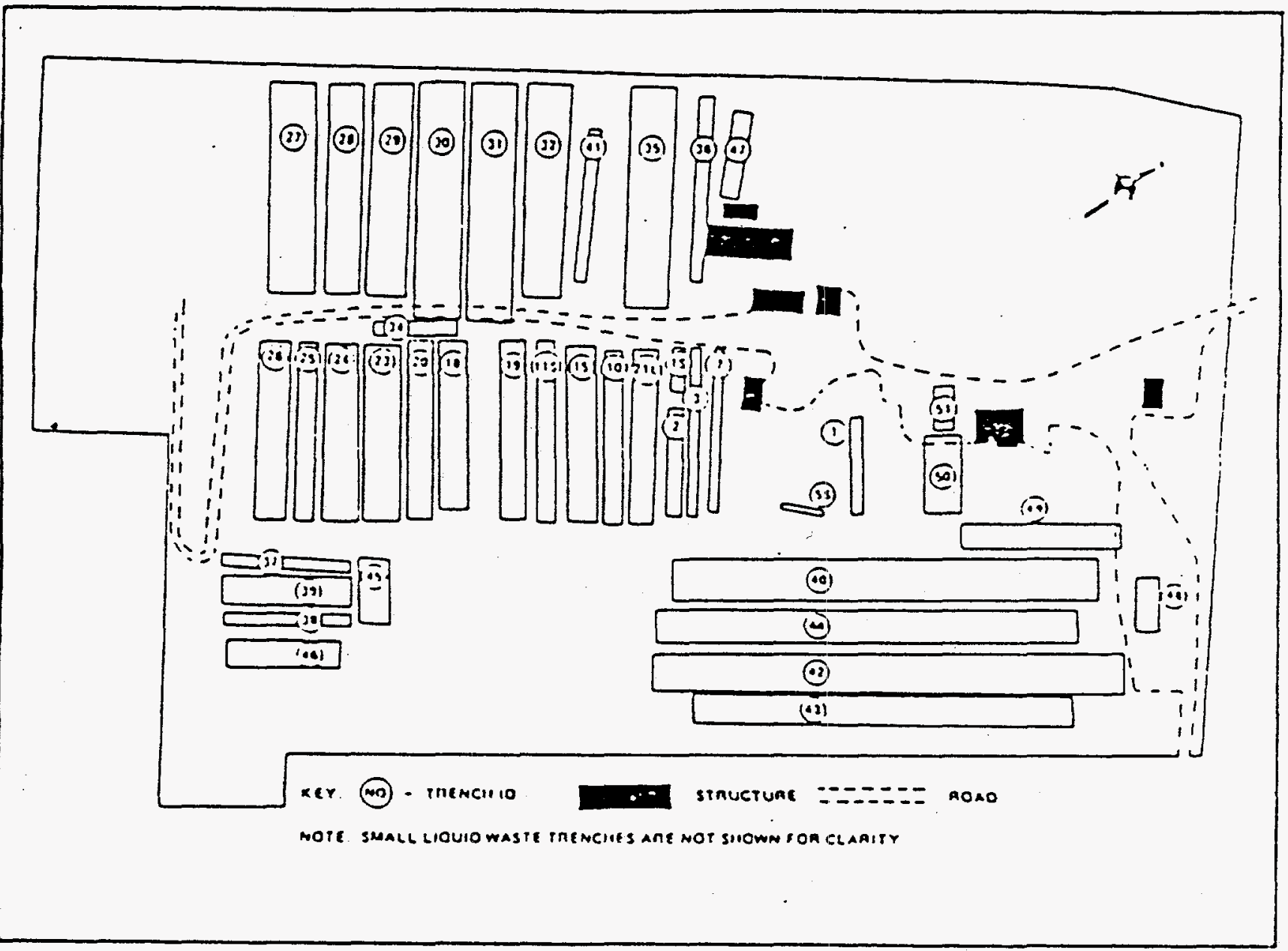

Figure 3-3. Trench locations as of 1987 at the Maxey Flats site.

lenses of fine-grained sandstone and siltstone. The clay-rich cover soils range in depth from less than 1 to $5 \mathrm{~m}$ ( 3 to $15 \mathrm{ft})$.

As site operations progressed, difficulties occurred due to the method of trench construction, waste placement, and closure..$^{3-2,3-3}$ Because the soils under the trenches were generally low in permeability, water collected in the open trenches during site operations (over the 1 to 1-1/2 years before trench cover installation). In addition, precipitation infiltrated through the trench covers and some water entered laterally from adjacent areas.

The waste form also became a significant factor. The original packages contained large void spaces. Degradation and decomposition (a process enhanced by contact with water) produced additional voids. The voids resulted in trench cap subsidence. Surface cracks or depressions were repaired regularly by placing additional fill over the affected area. 
Additional water filtered into the trenches and continued the cycle of water entry. ${ }^{3-4}$ By the early 1970 s, sufficient water had accumulated in the completed trenches that a water management program was implemented. Excess water was pumped out and either solidified or evaporated. Dewatering continued as rainfall infiltrated the trench area. ${ }^{3-2}$

Because the water volume was large and continually replenished by infiltration, pumping and treating was unable to remove all trench water. In addition, chemical agents present in the waste accelerated the leaching of radionuclides. To reduce the likelihood of water contacting the buried waste, site operations were modified, by grading to improve surface drainage, recapping older trenches to reduce cap permeability, improving new trench-capping procedures, establishing a vegetative cover over completed trenches (subsequently eliminated in favor of plastic), eliminating on-site ponds, installing additional trench sumps to facilitate water removal, routinely backfilling waste as it was placed in the trenches, and removing precipitation from the trenches while they were open and being filled.

Because of the Commonwealth's efforts to prevent vertical infiltration, removal of water ceased and the evaporator was shutdown in 1986.

\section{Volume}

Approximately $140,000 \mathrm{~m}^{3}\left(4.8\right.$ million $\left.\mathrm{ft}^{3}\right)$ of waste, containing over $89,000 \mathrm{TBq}(2.4$ million curies) of byproduct material, $431 \mathrm{~kg}(950 \mathrm{lb})$ of special nuclear material, and $240,000 \mathrm{~kg}(533,000 \mathrm{lb})$ of source material were buried during the period of commercial operation. The waste included plutonium, strontium, and gamma-emitting radionuclides. The most abundant radionuclide in the waste was tritium. Uncertainty exists regarding the activity of the waste because much of the waste sent to the site was labeled mixed fission products. In some trenches, approximately $50 \%$ of the waste was mixed fission products.

\section{Stabilization and Closure}

The radioactive materials license issued to the site operator required that disposal be halted when the waste had reached a level approximately $1 \mathrm{~m}(3 \mathrm{ft})$ below the original ground surface. One meter ( $3 \mathrm{ft}$ ) of soil was required to be placed over the waste. This soil cover was emplaced and contoured to promote drainage away from the trench. Figure 3-3 is a 1987 map showing the trench boundaries as best identified from old records, geophysical surveys, and trench dewatering well (sump) installations.

Since 1981 , over 11 hectares ( 28 acres) of the site surface have been covered with a polymer membrane (polyvinyl chloride). This trench surface cover, which limits the infiltration of surface water into the trenches, reduces the formation of trench leachate. Trench leachate is formed when water frees constituents from the waste. Several radionuclides have been leached and moved into the environment at differing rates. Although the trench surface cover is effective in reducing the infiltration of water from the surface, some leachate is still being produced.

In order to greatly reduce or prevent the percolation of water into the trenches, ${ }^{3-4}$ remedial actions are now being directed toward meeting the Kentucky's regulatory requirement for longer-term stability-both by building a long-lasting, water-repellant closure cap to shed rain water and snow melt 
(likely to extend over an area greater than is presently covered) and by horizontal ground water flow barriers.

\section{SITE}

\section{Topography}

The Maxey Flats site is in the Knobs region of Kentucky on a flat-topped ridge. This region was once a near-flat, upland area. Over time, the terrain was dissected by erosion and, as a result, now consists of a series of elevated, nearly-flat erosional terraces which are separated from wide, flat stream valleys at lower elevation by side slopes which have steep gradients, in excess of $40 \%$.

Maxey Flats is the name given to one of the larger terraces in the region, approximately $6 \mathrm{~km}$ (4 mi) in length, with an average width of about $450 \mathrm{~m}(1,500 \mathrm{ft})$. The terrace lies about $85 \mathrm{~m} \mathrm{(280 \textrm {ft } )}$ above the wide valley floors of Crane Creek to the north and Rock Lick Creek to the south. Surface topography of the terrace varies from 320 to $330 \mathrm{~m}(1,040$ to $1,060 \mathrm{ft})$ above sea level.

The portion of Maxey Flats occupied by the disposal site is a large southern spur of the terrace. The width of the terrace at the site varies from 400 to $600 \mathrm{~m}(1,200$ to $2,000 \mathrm{ft})$. The spur crest slopes gently to the south, while the disposal site area slopes gently to the west, east, and south..$^{3-5}$

\section{Climate}

The climate at the site is typical of the central part of the United States, which has a Koeppen classification of Continental, characterized by warm humid summers and cold winters. Frontal systems move across this portion of the United States from both west and north out of the Gulf of Alaska and Canada, and from southwest to northeast out of Gulf of Mexico.

The average annual precipitation measured (1941-1970) at Farmers, Kentucky, eight miles south of the site, is $102 \mathrm{~cm}$ (44.3 in.). The fall season characteristically has the least rainfall, while spring and early summer are the wettest seasons. Precipitation occurs in conjunction with major weather systems and from short-duration spring and summer thunderstorms. Rainfall which occurs during the high-intensity thunderstorms frequently exceeds 5 to $8 \mathrm{~cm}$ ( 2 to $3 \mathrm{in}$.) and occasionally 12 to $15 \mathrm{~cm}$ ( 5 to 6 in.).

Winds generally blow from the southwest in spring and early summer and from the south in the fall. The total annual evaporation rate, as determined from the U.S. Weather Bureau Climatic Atlas, is about $90 \mathrm{~cm}$ (35 in.). Approximately $75 \%$ of the evaporation occurs from May to October.

\section{Land Use}

The Maxey Flats site includes 102 hectares (252 acres) of rural land. Within the 17-hectare (42-acre) restricted area (Figure 3-2), 10 hectares (24 acres) were used for waste disposal. 
At the beginning of the 1990s, approximately 57 residential structures existed within a $1.5 \mathrm{~km}(1$ mi) radius of the Maxey Flats site, housing approximately 152 persons. ${ }^{3-6}$ In an area between 1.5 and 4 $\mathrm{km}$ ( 1 to $2.5 \mathrm{mi}$ ) distant, 192 residential structures house approximately 511 persons. Of this estimated 663 persons within $4 \mathrm{~km}(2.5 \mathrm{mi})$, an estimated $148(22.3 \%)$ are women of childbearing age (15 to 44 years old), and an estimated 148 (22.3\%) are children (under age 14). Approximately 11 residences are within $1 \mathrm{~km}(0.5 \mathrm{mi})$ radius, with an actual population of 25 persons (14 male and 11 female).$^{3-6}$

\section{Geology}

The Maxey Flats area is underlain by Mississippian and older sedimentary rocks. Table 3-1 is a summary of the stratigraphic sequence exposed in the vicinity of the site. The site subsurface is representative of the eastern flank of the Cincinnati Arch and consists generally of gently-dipping sedimentary rocks, including clay-shale, siltstone, fine-grained sandstone, and fissile carbonaceous shale..$^{3-2,3-7}$ Disposal trenches were located within the weathered surface soils and the Nancy Member of the Borden Formation. Near-vertical fractures are common in the media underlying the site, but the detailed locations and extent of fractured formations cannot be ascertained. The stratigraphic sequence extends to the Crab Orchard Formation because this formation is considered to be the lower boundary to the ground water system in the vicinity. ${ }^{3-7}$

The uppermost rock unit is the Nancy Member of the Borden Formation, which is predominantly a massive, poorly-fissile, dark-blue-to-greenish shale interbedded with lenses of finely-grained sandstone and siltstone. When excavations are made within the Nancy Member, the shales which comprise the majority of this member deteriorate along the excavated surface, causing the shales to appear cracked and broken. Stress relief occasioned by the excavation and weathering due to exposure

Table 3-1. Stratigraphy of the Maxey Flats site. ${ }^{3-2}$

\begin{tabular}{|c|c|c|}
\hline Geologic formation & Description & $\begin{array}{l}\text { Average thickness } \\
\text { (ft) }\end{array}$ \\
\hline \multirow[t]{3}{*}{ Borden formation } & $\begin{array}{l}\text { Nancy Member-Predominantly massive shale, with } \\
\text { some thin sandstone layers, irregularly spaced } \\
\text { vertical joints }(0.5-0.25 \mathrm{~m}, 2-10 \text { in. })\end{array}$ & 45 \\
\hline & $\begin{array}{l}\text { Farmer Member-Predominantly sandstone, silty } \\
\text { sandstone with minor shale; vertical joints } \\
\text { (predominantly in the upper portion) }\end{array}$ & 35 \\
\hline & $\begin{array}{l}\text { Henley Bed-Basal portion of the Farmers Member; } \\
\text { commonly contains a few sandstone beds or lenses } \\
0.3-0.6 \mathrm{~m}(1-2 \mathrm{ft}) \text { thick in upper part }\end{array}$ & 6 \\
\hline Sunbury shale & Fissile black shale with vertical joints & 18 \\
\hline Bedford shale & $\begin{array}{l}\text { Bluish-gray shale with thin sandstone with vertical } \\
\text { joints }\end{array}$ & 25 \\
\hline Ohio shale & Fissile black shale & 185 \\
\hline Crab orchard & Greenish-gray poorly fissile shale (upper portion) & $80-130$ \\
\hline
\end{tabular}


of the shale to the atmosphere is the likely cause. ${ }^{3-2}$ This condition is not representative of the Nancy Member where the shales are not weathered or exposed at the surface.

Weathering of the Nancy Member forms the regolith at Maxey Flats. The sandstone beds are very fine grained silty sandstones in some areas, but are siltstones in others. An upper sandstone bed is

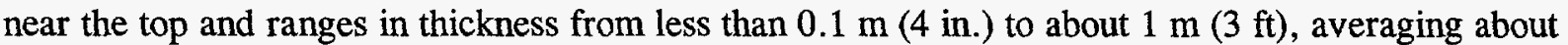
$0.5 \mathrm{~m}(1.5 \mathrm{ft})$. The lower sandstone bed is near the middle of the regolith and ranges in thickness from 0.1 to $1 \mathrm{~m}$ (less than $4 \mathrm{in}$. to $3 \mathrm{ft}$ ), and averages about $0.3 \mathrm{~m}(1 \mathrm{ft})$. The sandstone beds are absent locally due to nondeposition or erosion of the upper bed in places but both are present over most of the Maxey Flats site. ${ }^{3-2}$

The Farmer Member (a sandstone unit) is exposed in the East Main Drainage Channel to the east and south of the site, where it stands nearly vertically and serves as a barrier to erosion. The Farmer Member is not exposed on the western slope which is covered with regolith to the valley floor.

The hillsides at the site are covered with a layer of rock fragments and soil materials referred to as colluvium. The colluvium extends to the valleys, where it is referred to as alluvium.

\section{Surface Water}

The entire Maxey Flats region lies in the watershed basin of the Licking River, which drains into the Ohio River near Cincinnati, Ohio. Greater than $90 \%$ of the water draining the 102 hectare (252 acres) site discharges to Rock Lick Creek, which empties into Fox Creek. Fox Creek enters the Licking.

Drainage to the east carries approximately $62 \%$ of the surface water exiting the restricted area. Discharge over the eastern slope is regulated by a detention pond which discharges into an unnamed hollow (referred to as No Name Creek).

Approximately $15 \%$ of the site restricted area drains to the south directly into Rock Lick Creek. Approximately $20 \%$ discharges via the west detention pond into Drip Springs Creek which empties into Rock Lick Creek.

\section{Ground Water}

The shales and fine-grained sandstones of the site generally have low primary permeability. Ground water flow occurs mainly in joints and fractures in these rocks.

Water is found in the rock structure beneath the site, in at least two separate units. Water levels

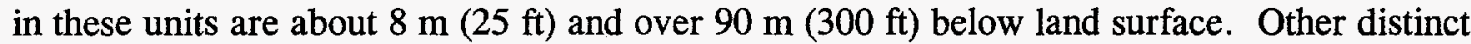
hydrologic units may be present, but have not been identified.

The hydrological characteristics of the relatively shallow (average $12 \mathrm{~m}$ or $40 \mathrm{ft}$ ) Nancy Member of the Borden Formation are of particular importance because all waste burial trenches were 
constructed in these strata. Also, most problems, such as the accumulation of water in the trenches and subsurface lateral migration of leachate, result from movement of water in these strata.

The importance of the upper and lower sandstone beds to ground water recharge and discharge became more apparent after drilling by the U.S. Geological Survey (USGS). Abrupt changes in the occurrence, thickness, amount of fracturing and its orientation (particularly with regard to the lower bed) were found to be characteristic of, and appear to determine, the movement of water from the trenches to perimeter wells. ${ }^{3-8}$

Previous estimates ${ }^{3-2,3-7}$ of ground water flow in the lower sandstone bed were $15 \mathrm{~m} / \mathrm{y}(50 \mathrm{ft} / \mathrm{y})$. Based on yields of wells on the west hillside, this estimate may be low by one or more orders of magnitude. Radionuclide and organic chemical movement has been found in ground water flowing in the lower sandstone bed in a triangular shaped area in the northwestern section of the site.

The extent of contaminated ground water appears to be controlled by the thickness of the lower sandstone bed beneath the south edge of Trench 41, the plugging of fractures with colluvium just inside the western hillside outcrop area, and the complete absence of the lower bed along a line from the east end of Trench 41 to a point near the northwest fence. The absence of this lower bed apparently prohibits the lateral movement of contaminated water from reaching other subsurface or outcrop areas. $^{3-8}$ Subsurface migration occurs from trenches south of Trench 41. Trench 41 received little waste and was closed early; furthermore, Trench 35 is the only major trench north of Trench $41 . .^{3-11}$

The rate at which rainfall percolates to the ground water system is low because of the silty nature of the surface soils and the consistently high runoff of incident precipitation. Ground water circulation within shallow ground water systems is influenced by the topography of the areas. Extreme relief enhances lateral ground water flow toward topographically low areas. Because of the presence of low permeability shales, much of the water which does percolate to the ground water system discharges through hillsides rather than recharging the deeper strata. Only about $10 \%$ of the water which infiltrates the bedrock at the burial site is estimated to percolate to the Ohio shale. ${ }^{3-7}$ This conceptual flow model of the site indicates that $70 \%$ of the water which infiltrates the site bedrock discharges to the hillside above the lower part of the Farmers Member. ${ }^{3-7}$

Ground water discharging to the ground surface on hillsides may be evaporated, transpired, or may eventually flow into the valley alluvium of Rock Lick Creek. Ground water discharge from rocks underlying the trench area may contribute as much as $0.5 \%$ of the mean annual base flow of Rock Lick Creek. ${ }^{3-7}$ This percentage is further diluted by surface runoff. An average dilution factor of 2,000 is estimated at the USGS gaging station on Rock Lick Creek, ${ }^{3-7}$ with mean annual base flow at the USGS gaging station estimated to be $7 \mathrm{~m}^{3} / \mathrm{s}-\mathrm{d}\left(240 \mathrm{ft}^{3} / \mathrm{s}-\mathrm{d}\right)$.

\section{Ecology}

The site is in a humid environment. Predominantly oak-hickory forests occupy the steep slopes on the eastern, southern, and western sides of the site. The forests, because of their locations in relation to the burial trenches, are in a position to intercept radionuclides that might be transported downslope (Figure 3-4) by surface water runoff or subterranean water flow from the site. ${ }^{3-4}$ 


\section{ENVIRONMENTAL MONITORING}

\section{Overview}

In October 1974, Kentucky informed the U.S. Atomic Energy Commission (predecessor of NRC) of the results of a special six-month environmental study at Maxey Flats. ${ }^{3-9}$ The study concluded that the disposal site was contributing trace amounts of radioactivity to the local environment, although the

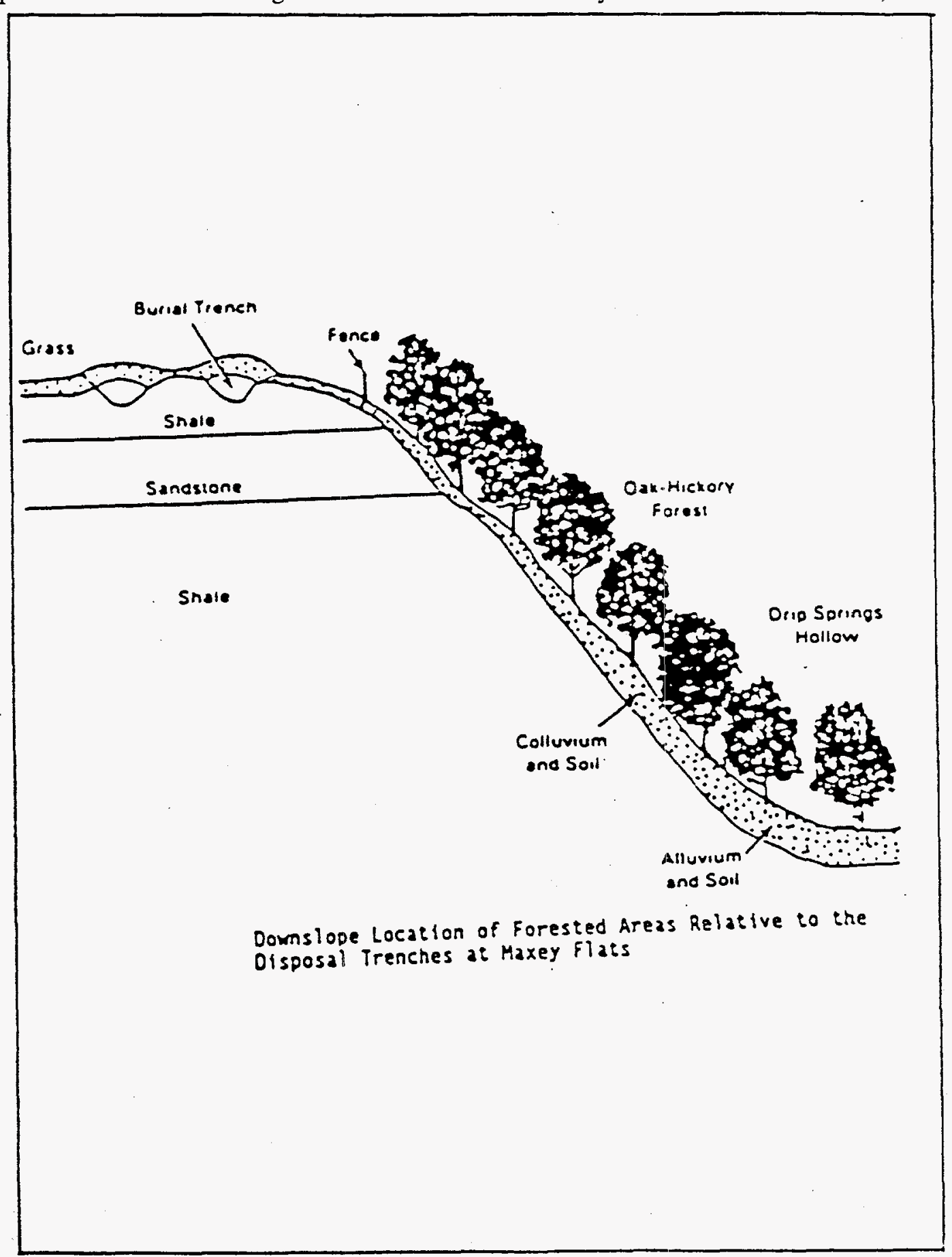

Figure 3-4. Downslope location of forested areas relation to the Maxey Flats site. 
levels did not represent a public health hazard. Tritium, cobalt-60, strontium-89, strontium-90, cesium-134, cesium-137, plutonium-238, and plutonium-239 were identified in individual samples in the unrestricted environment. Kentucky recommended longer-term studies at the facility to assess the health and safety significance of their findings.

In 1977, radioactivity in water was detected moving through the joints of a sandstone bed, a distance of approximately $90 \mathrm{~m}$ (300 ft) from the apparent source trench. In May 1977, Trench 46 was opened and water was detected on the side wall. The events associated with this subsurface movement resulted in closure of the site to commercial waste by the Cabinet in December 1977..$^{3-11}$

Interpreting data from the site environs is complicated by the fact that other past routes existed for radionuclide movement besides subsurface aquifer transport. Radioactive liquids were spilled. Reworking of trench subsidence areas to form new caps resulted in localized spread of contamination, although removal action has reduced the amount of this radioactivity now available for surface dispersal to the off-site environment. At least four pathways have been identified since the 1970's by studies carried out by the Commonwealth of Kentucky, Commonwealth contractors, the NRC, the U.S. Geological Survey (USGS), and the U.S. Department of Energy (DOE):

1. Surface water runoff

2. Atmospheric fallout from the evaporator (prior to closing in 1986)

3. Lateral movement of liquids from trenches through the soil

4. Movement of liquids from the trenches through fractures in the surrounding rock.

Features of the site which create ongoing conditions which affect the environmental monitoring are:

- The very low overall permeability of the rock formations at the site which allow accumulation of liquids within the trenches

- Fractures, which exhibit a much greater permeability than the unfractured bulk of the rock, creating uncertainty regarding the direction and occurrence of ground water movement and making a thorough understanding of hydrologic conditions at the site difficult. This in turn makes it difficult to implement a ground water monitoring program that will give a high level of assurance that migration will be observed, should it occur

- Long-term consolidation of loosely placed waste in the trenches, leading to subsidence events which can damage trench cover and increase infiltration of precipitation

- Accumulation of water in contact with the waste for a period of time sufficient to become contaminated, creating a potential environmental hazard if the leachate exits the trench by fracture flow or overflow 
- The controlled migration of radionuclides and other hazardous materials to the environment-leachate buildup within the trenches was controlled by pumping it and processing it through the leachate evaporator system for volume reduction, with some release of radionuclides to the atmosphere ${ }^{3-10}$ Leachate is no longer removed from the trenches. The site has stabilized in regards to infiltration/exfiltration because of the presence of covers.

The Kentucky Radiation Control Branch routine environmental monitoring program at the Maxey Flats site is designed to address these features of and pathways for potential release of radioactivity from the site. For example, sampling in 1991 included surface water (off-site and washes), drinking water wells, USGS test wells, and soil lysimeters. During 1991, 2,209 water samples were collected to a distance of $7 \mathrm{~km}$ (4.5 air mi). The Kentucky Radiation Control Branch Laboratory conducted 7,788 analyses and 4,894 additional quality control analyses to insure the accuracy and precision of the tests.

All water samples collected are analyzed for tritiated water (HTO) and gross alpha and beta radioactivity. Water samples from selected locations are analyzed for gamma-emitters, strontium-90, and specific alpha-emitters by alpha spectroscopy. Extended radionuclide and other analyses (gammaemitters, carbon-14, strontium-90, plutonium, uranium, HTO, pH conductivity, and gross alpha and beta) are conducted on water from the USGS test wells surrounding the site and the seeps on the east hillside. The radionuclide analyses of the water samples provide valuable information regarding the spread of contamination from the burial trenches. Sampling frequency and locations are such that any changes in radionuclide levels would be detected within sufficient time for remedial action to be formulated..$^{3-11}$

\section{Ground Water}

In order to characterize the ground water conditions of the site, over 100 wells have been drilled as part of the site evaluation and site monitoring activities. Locations of all wells (except the initial eight wells installed prior to site operation) are shown in Figure 3-5. None of these sampling points are usable as drinking water sources because of their locations in and around the controlled area. A history of the drilling program and details of the well designs are available..$^{3-7,3-12,3-13,3-14}$

Many of the wells have very low water yields. As a result, representative periodic sampling proved to be difficult. Samples were bailed mechanically from the wells or sampled with a non-contaminating pump (peristaltic).

Generally, ground water samples are analyzed for tritium oxide concentrations and specific conductance. When the volume of the sample is sufficient, analysis includes gross alpha activity concentrations, gross beta activity concentrations, and concentrations of gamma-emitting radionuclides. Since the ground water monitoring program is intended to provide advance warning of radionuclide escape, analysis of samples for tritium activity is given priority. This is appropriate since tritium, appearing in the form of tritiated water, travels at the same rate as the ground water; dissolved or suspended radionuclides travel at slower rates. Tritium will likely precede the escape of other radioactive materials by a considerable period. Data from well samples collected during 1987-1989 are presented in Table 3-2. 
Table 3-2. Selected ground water well sampling data for tritium $(\mathrm{pCi} / \mathrm{L})$ at the Maxey Flats site. . $^{3-10,3-15,3-16}$

\begin{tabular}{llll}
\hline Well name & 1987 & 1988 & 1989 \\
\hline N2B & $8.7 \times 10^{8}$ & $1.8 \times 10^{8}$ & $5.8 \times 10^{8}$ \\
UE-1 & $1.4 \times 10^{9}$ & $1.7 \times 10^{9}$ & $1.9 \times 10^{9}$ \\
UE-2 & $1.1 \times 10^{9}$ & $1.3 \times 10^{9}$ & $1.7 \times 10^{9}$ \\
UE-3 & $6.2 \times 10^{8}$ & $5.2 \times 10^{8}$ & $3.6 \times 10^{8}$ \\
UG-1 & $6.5 \times 10^{8}$ & & \\
UG-2 & $1.5 \times 10^{8}$ & $1.2 \times 10^{8}$ & $1.2 \times 10^{8}$ \\
UG-12 & $1.5 \times 10^{8}$ & $1.6 \times 10^{8}$ & $1.5 \times 10^{8}$ \\
UK-1 & $6.0 \times 10^{8}$ & $8.5 \times 10^{7}$ & $8.8 \times 10^{7}$ \\
UK-2 & $2.3 \times 10^{9}$ & $1.1 \times 10^{9}$ & $9.7 \times 10^{9}$ \\
UK-4 & $1.0 \times 10^{3}$ & $1.2 \times 10^{9}$ & $1.8 \times 10^{9}$ \\
UK-6 & $8.0 \times 10^{2}$ & $<4.0 \times 10^{2}$ & $5.0 \times 10^{2}$ \\
& & $6.0 \times 10^{2}$ & $2.6 \times 10^{3}$ \\
UF-1 & & & \\
UF-2 & $8.7 \times 10^{8}$ & $8.2 \times 10^{8}$ & $8.2 \times 10^{8}$ \\
UF-11 & $8.7 \times 10^{8}$ & $7.2 \times 10^{8}$ & $8.5 \times 10^{8}$ \\
UF-20 & $1.0 \times 10^{3}$ & $8.0 \times 10^{2}$ & $4.0 \times 10^{2}$ \\
UF-38 & $2.0 \times 10^{3}$ & $1.4 \times 10^{3}$ & $1.1 \times 10^{3}$ \\
UF-47 & $7.0 \times 10^{3}$ & $5.0 \times 10^{3}$ & $5.0 \times 10^{3}$ \\
& $1.1 \times 10^{4}$ & $1.9 \times 10^{4}$ & $1.1 \times 10^{4}$ \\
\hline
\end{tabular}

Table 3-3. Kentucky maximum permissible concentrations of radioactivity in air and water. ${ }^{3-17}$

\begin{tabular}{llllll} 
& \multicolumn{2}{c}{$\begin{array}{c}\text { Air } \\
\left(\mathrm{pCi} / \mathrm{m}^{3}\right)\end{array}$} & & \multicolumn{2}{c}{$\begin{array}{c}\text { Water } \\
(\mathrm{pCi} / \mathrm{L})\end{array}$} \\
\cline { 2 - 3 } \cline { 6 - 7 } & Soluble & Insoluble & & Soluble & Insoluble \\
\hline Tritium & $2 \times 10^{5}$ & $2 \times 10^{5}$ & & $3 \times 10^{6}$ & $3 \times 10^{6}$ \\
Cobalt-60 & $1 \times 10^{4}$ & $3 \times 10^{2}$ & & $5 \times 10^{4}$ & $3 \times 10^{4}$ \\
Cesium-137 & $2 \times 10^{3}$ & $5 \times 10^{2}$ & & $2 \times 10^{4}$ & $4 \times 10^{4}$ \\
Strontium-90 & $3 \times 10^{1}$ & $2 \times 10^{2}$ & & $3 \times 10^{2}$ & $4 \times 10^{4}$ \\
Plutonium-238 & $7 \times 10^{-2}$ & 1 & & $5 \times 10^{3}$ & $3 \times 10^{4}$ \\
Plutonium-239/240 & $6 \times 10^{-2}$ & 1 & & $5 \times 10^{3}$ & $3 \times 10^{4}$ \\
\hline
\end{tabular}




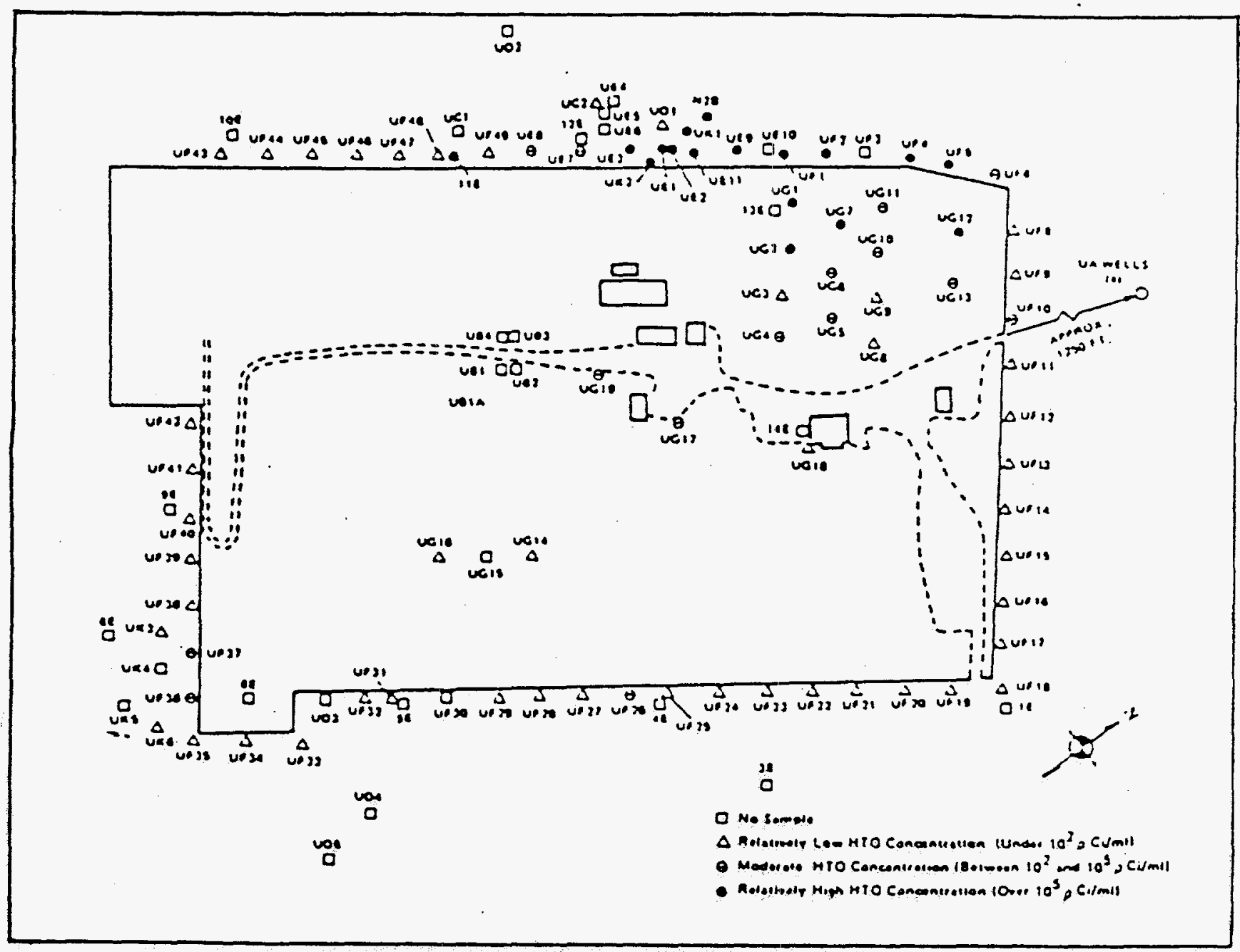

Figure 3-5. Well locations and tritium concentrations $(\mathrm{pCi} / \mathrm{mL})$ at the Maxey Flats site.

Water collected from wells located on the western boundary of the site restricted area contain the highest tritium levels. These may be compared to Kentucky regulations (Table 3-3). The highest average annual concentration of tritium observed was $9.7 \times 10^{9} \mathrm{pCi} / \mathrm{L}$ at Well UK-1 (Figure 3-5), which is located near Trench 35 along the site restricted area fence. Generally, as illustrated in Figure 3-5, the highest concentrations of tritium oxide in ground water were observed in this area. The high concentrations in the wells in the northwest quadrant of the site suggest that trench leachate has moved via the lower sandstone marker bed to distances of over $150 \mathrm{~m}$ (500 ft) from the trench area. Of the 78 wells sampled in both 1986 and 1987, 14 wells demonstrated an increase in average tritium concentrations, 33 had declines, and 33 showed no significant change.

\section{Surface Water}

Surface water samples are collected on the site and off-site, including washes, to a distance of 7 $\mathrm{km}$ (4.5 air mi).

Mean tritiated water concentrations for off-site sample locations-outside or at the site boundary-ranged from $1.1 \times 10^{5} \mathrm{pCi} / \mathrm{L}$ at the site boundary in the East Main Drainage Channel to 
$100 \mathrm{pCi} / \mathrm{L}$ in Rock Lick Creek about $3 \mathrm{~km}(2 \mathrm{mi})$ upstream from where No Name Creek empties into Rock Lick Creek.

Erosion continues to be a problem in all drainage areas and especially in the East Main Drainage Channel and Wash 7 on the west hillside. If erosion continues in these drainage areas, migration pathways could be intercepted leading to an increased release of radionuclides. Erosion control in the East Main Drainage Channel is critical to the stability of the site in light of the finding of seeps and springs along the east hillside.

Locations in the north drain of Trench 33L on the west hillside and the East Main Drainage Channel showed mean HTO concentrations which ranged from $3 \times 10^{3}$ to $2 \times 10^{6} \mathrm{pCi} / \mathrm{L}$; however, many of these locations were dry for a substantial part of 1991. In the East Main Drainage Channel (at approximately $250 \mathrm{~m}-800 \mathrm{ft}$-above mean sea level, which can be sampled throughout the year), the mean HTO concentration was $3.1 \times 10^{5} \mathrm{pCi} / \mathrm{L}$ for 1991 , compared to $2.7 \times 10^{5} \mathrm{pCi} / \mathrm{L}$ for $1990 .^{3-11}$ The elevated HTO at surface water location 144 is a result of the leaching of radionuclides from EPA solidified leachate stored on-site until November 1991 and from subsurface movement to the east drainage areas from the disposal trenches. The activity of HTO at location 144 did increase by the placement of waste solidified and stored on-site; however, migration is occurring from the 40 Series trenches to the east hillside and then into the main drainage channel. Seeps were first detected in August 1990 by the Radiation Control Branch and these seeps are routinely monitored. The soils in the area of the seeps are saturated at the ground surface during all seasons. The saturated area is expanding down slope towards the east main drain. Since the activity of HTO in the seep water is approximately $20,000 \mathrm{pCi} / \mathrm{ml}$, saturation movement closer to the main drainage area could have a major impact on activity levels at location $144 .^{3-11}$

\section{Biota}

Vegetation samples have been taken from pasture fields adjacent to the site and from a garden located almost $500 \mathrm{~m}(550 \mathrm{yd})$ north of the site's main office building. Vegetation samples are analyzed by various methods to determine the concentrations of tritium, strontium- 90 , plutonium-238, $\mathrm{Pu}-239 / 240$, and gamma-emitting nuclides present. Tritium, strontium, and plutonium are present in measurable concentrations for all samples except cucumbers and tomatoes; tritium was not detected in the cucumber and tomato samples. No gamma-emitting radionuclides were reported above the minimum detection limits.

Nonradiological samples collected in the food crop study area indicate no site-related hazardous chemical contamination in these off-site locations. Dieldrin, a pesticide detected in one food crop sample, is likely to be related to farming activities rather than the site.

\section{Soils}

Toluene was the most widely-detected chemical contaminant at the Maxey Flats site, ranging from 40 to 250 parts per billion ( $\mathrm{ppb}$ ). Other volatile organic contaminants detected in soils include acetone and methylene chloride in low concentrations. Pesticides, polychlorinated biphenyls (PCBs), and semivolatile contaminants were not detected in study area soil, with the exception of dieldrin, which was detected in a food crop study area. All soil samples showed inorganic chemical concentrations within 
ranges considered normal for soils, with the exception of arsenic, which was found at 60 to 106 parts per million. Organic and inorganic analyses performed on these soil samples indicate that standard toxicity test (EP toxicity and TCLP) results would be negative and that other hazardous constituents would be within standards (under regulations of the Resource Conservation and Recovery Act).

\section{SUMMARY}

Radioactive materials, as described in the previous sections, were released to the environment as a result of the ongoing operations to stabilize and decommission the Maxey Flats site. These materials include radionuclides such as tritium (generally, in the form of tritiated water), strontium-90, plutonium (in Pu-238, Pu-239, and Pu-240), and various gamma-emitting radionuclides, such as cesium-137.

The Kentucky Radiation Control Branch has concluded $d^{3-11}$ that analyses of test wells, soil moisture, seeps and surface water indicate that water continues to accumulate in the trenches and exfiltration from the trenches continues to occur. The radioactive material leaving the site is diluted substantially as it enters the environment. Direct measurement of the impact of the diluted concentrations of radioactive material is impractical; pathways followed by these materials to humans are evaluated using computer models and potential doses are calculated. All such calculations have documented very low exposures for all pathways. No exposures to the general public exceed federal or Kentucky regulatory standards. ${ }^{3-11}$ 


\section{REFERENCES}

3-1. U.S. Environmental Protection Agency, Summary of Remedial Alternative Selection, Record of Decision Remedial Alternative Selection, Maxey Flats Disposal Site, Fleming County, Kentucky, U.S. EPA Region IV, Atlanta, Georgia (1992).

3-2. H. H. Zehner, Hydrogeologic Investigation of the Maxey Flats Radioactive Waste Burial Site, Fleming County, Kentucky, U.S. Geological Survey Open File Report 83-133, Louisville, Kentucky (1983).

3-3. Grant (1982).

3-4. L. J. Kirby, "Radionuclide Distributions and Migration Mechanisms at Shallow Land Burial Sites," U.S. Nuclear Regulatory Commission NUREG/CR-4670, PNL-7582, prepared by Pacific Northwest Laboratory, Richland, Washington (1991).

3-5. Kentucky Department of Natural Resources and Environmental Protection, Results of the Environmental Monitoring Program at the Maxey Flats Disposal Site in Fleming County, Kentucky, Westinghouse Electric Corporation, Madison, Pennsylvania (ETD-DN-00044) (1987).

3-6. U.S. Environmental Protection Agency, Summary of Remedial Alternative Selection, Record of Decision Remedial Alternative Selection, Maxey Flats Disposal Site, Fleming County, Kentucky, U.S. EPA Region IV, Atlanta, Georgia (1992).

3-7. H. H. Zehner, Preliminary Hydrogeologic Investigation of the Maxey Flats Radioactive Waste Burial Site, Fleming County, Kentucky, U.S. Geological Survey Open File Report 79-1329, Louisville, Kentucky (1979).

3-8. M. A. Lyverse, Movement of Tritiated Leachate through Fractured Rocks at a Low-Level Radioactive Waste Disposal Site Near Morehead, Kentucky. Proc. 3d Ann Regional Ground-Water Conf., Nat. Water Well Assoc. (1986).

3-9. Kentucky Department of Human Resources, Six-month Study of Radiation Concentrations and Transport Mechanisms at the Maxey Flats Area of Fleming County, Kentucky, Open File Report (1974).

3-10. Kentucky Department of Natural Resources and Environmental Protection, "Environmental Monitoring Program Results," Maxey Flats Disposal Site, January 1987 through December 1987, Fleming County, Kentucky.

3-11. J. A. Volpe, Commonwealth of Kentucky, Cabinet for Human Resources, Radiation Control Branch, Personal Communication on Environmental Monitoring Program at the Maxey Flats Site (1992 and 1996). 
3-12. EMCON Associates, "Geotechnical Investigation and Waste Management Studies," Nuclear Waste Disposal Associates, San Jose, California (1975).

3-13. Westinghouse Hittman Nuclear Incorporated, "Results of the Environmental Monitoring Program at the Maxey Flats Disposal Site in Fleming County, KY- January 1984 through December 1984," Columbia, Maryland.

3-14. Westinghouse Hittman Nuclear Incorporated, "Results of the Environmental Monitoring Program at the Maxey Flats Disposal Site in Fleming County, KY-January 1986 through December 1986," Columbia, Maryland.

3-15. Kentucky Department of Natural Resources and Environmental Protection, "Environmental Monitoring Program Results," Maxey Flats Disposal Site, January 1988 through December 1988, Fleming County, Kentucky (June 29, 1990).

3-16. Kentucky Department of Natural Resources and Environmental Protection, "Environmental Monitoring Program Results," Maxey Flats Disposal Site, January 1989 through December 1989, Fleming County, Kentucky (June 30, 1990).

3-17. Kentucky Administrative Regulations, 902 KAR 100:025, Table II, Frankfort, Kentucky (1992). 


\title{
CHAPTER 4
}

\section{Environmental Summary of the Beatty, Nevada Low-Level Radioactive Waste Disposal Site}

\author{
INTRODUCTION
}

\section{Background}

The Beatty, Nevada low-level radioactive waste (LLW) disposal facility operated by US Ecology was the first commercial low-level radioactive waste site in the United States. The Beatty site began operations in September 1962, and was closed on December 31, 1992. The LLW facility occupies 0.17 square kilometers ( 40 acres) of a 0.34 square kilometers ( 80 acres) tract which is leased to US Ecology by the State of Nevada (Figure 4-1). The remainder of the approximately 0.14 square kilometers ( 33 acres) is used for the disposal of hazardous chemical and toxic wastes (including PCBs). The hazardous waste site was licensed in 1970 under EPA Permit No. 330010000.

The Beatty site was originally operated by California Nuclear, Inc., and then by Nuclear Engineering Company (NECO), which is now known as US Ecology. Activities at the site are regulated by the Radiological Health Section of the Nevada State Department of Human Resources. Nevada is an Agreement State, with licensing authority delegated by the U.S. Nuclear Regulatory Commission (NRC). The site operator (US Ecology) holds a radioactive material license from the State of Nevada.

Although the State of Nevada assumed licensing responsibility for the site in 1972, the AEC, and later the NRC, retained regulatory responsibility for special nuclear material until 1977, during which time the state regulated source and byproduct materials. In 1977, the NRC license was cancelled and the state assumed licensing responsibility for all activities at the site.

\section{Location}

The Beatty LLW facility is located in Nye County, Nevada (latitude N $36^{\circ} 46^{\prime} 69^{\prime \prime}$, longitude W $\left.116^{\circ} 41^{\prime} 23^{\prime \prime}\right)$, in the Amargosa Desert, approximately $17.7 \mathrm{~km}$ (11 mi) south of the town of Beatty, and $169 \mathrm{~km}(105 \mathrm{mi})$ northwest of Las Vegas, Nevada (Figure 4-1).

\section{Facility}

From September 1962 through December 1992, the site received a total volume of 139,500 cubic meters (4.93 million cubic feet) of low-level radioactive waste, with a total radioactivity of approximately $2.65 \mathrm{E}+16$ becquerels ( 0.715 million curies) (Table $4-1)$. The LLW facility is separated 


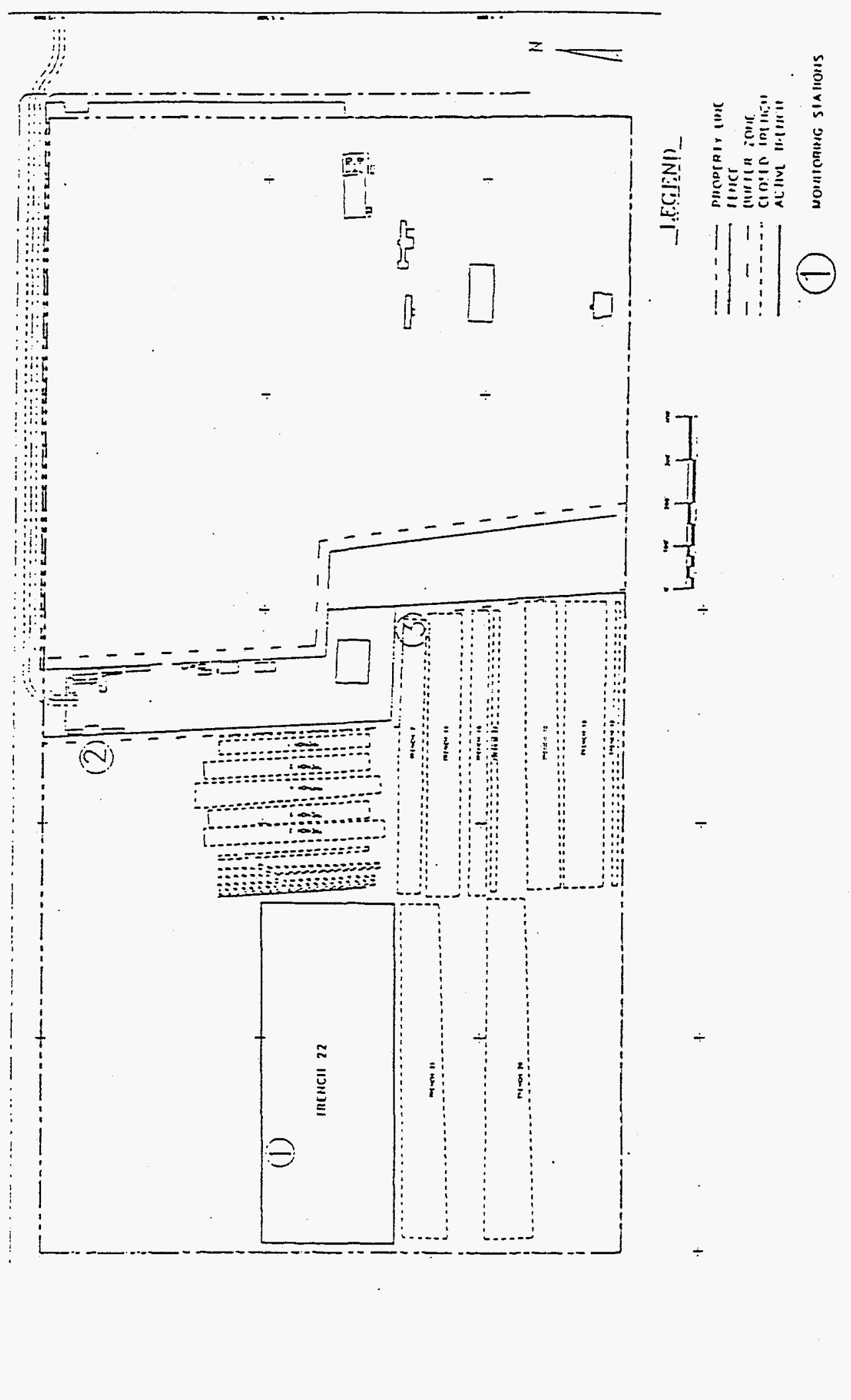




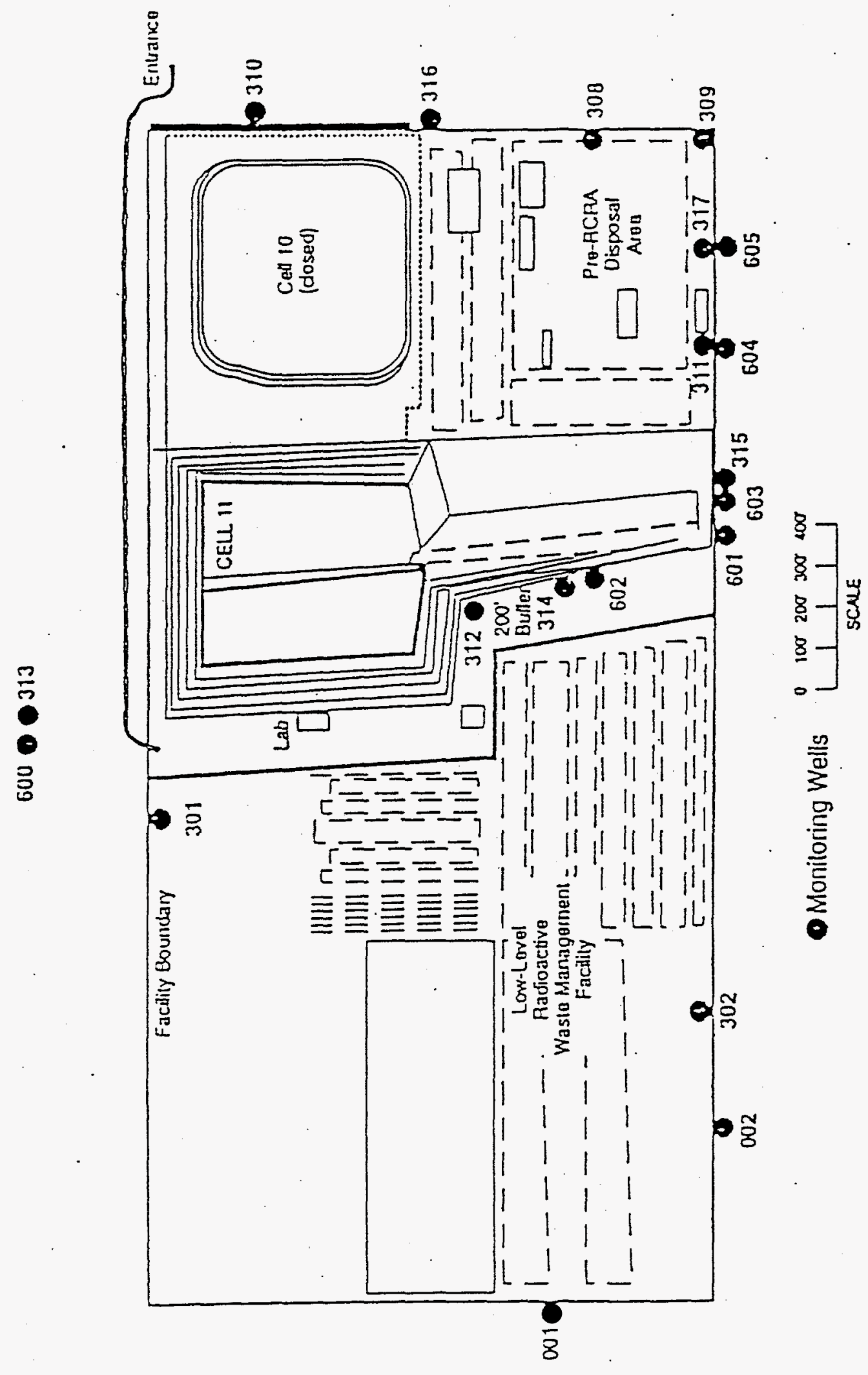

空 
Table 4-1. History of radioactive waste disposal volume and activity at the Beatty LLW site, 1962-1992.

\begin{tabular}{|c|c|c|}
\hline Year & Cubic feet & Curies \\
\hline $1962-1965$ & 371,500 & 19,400 \\
\hline 1966 & 173,800 & 14,000 \\
\hline 1967 & 94,300 & 11,000 \\
\hline 1968 & 131,800 & 7,100 \\
\hline 1969 & 159,900 & 9,800 \\
\hline 1970 & 145,900 & 6,700 \\
\hline 1971 & 173,600 & 4,000 \\
\hline 1972 & 151,900 & 5,800 \\
\hline 1973 & 134,700 & 10,600 \\
\hline 1974 & 144,900 & 23,000 \\
\hline 1975 & 174,200 & 15,800 \\
\hline 1976 & 136,400 & 2,500 \\
\hline 1977 & 177,500 & 22,800 \\
\hline 1978 & 301,700 & 4,800 \\
\hline 1979 & 230,700 & 9,800 \\
\hline 1980 & 450,100 & 146,300 \\
\hline 1981 & 188,300 & 46,100 \\
\hline 1982 & 52,700 & 80,800 \\
\hline 1983 & 39,200 & 1,400 \\
\hline 1984 & 72,900 & 500 \\
\hline 1985 & 48,800 & 500 \\
\hline 1986 & 92,000 & 700 \\
\hline 1987 & 336,000 & 11,000 \\
\hline 1988 & 93,400 & 86,900 \\
\hline 1989 & 116,200 & 42,700 \\
\hline 1990 & 59,500 & 11,300 \\
\hline 1991 & 160,300 & 29,700 \\
\hline 1992 & 514,700 & 90,200 \\
\hline TOTAL & $4,926,900$ & 715,200 \\
\hline
\end{tabular}


vehicles were frequently driven down ramps, and the waste was offloaded directly into the trench. Three feet of final backfill were placed over the filled trenches. An additional two feet of soil were then used as an interim cover. The radioactive waste was placed into 22 separate disposal trenches, which are identified by permanent concrete posts marked with the trench number, dates opened and closed, trench boundary coordinates, and waste characteristics; i.e., total volume and activity, as well as the quantity of source and special nuclear materials. The site records are keyed to these markers. US Ecology maintained records of waste received at the site, and compiled periodic summaries during the years of operation.

Between March 1976 and December 1979, a series of events involving the improper handling and disposal of low-level radioactive waste resulted in the temporary suspension of the site operator's radioactive materials license. Although no significant radiation exposures were reported for the workers or the public, a number of new license conditions were imposed, with the objective of tightening management control over the site operations, generators, and shippers of the waste. Additionally, a permitting system for waste shipments was established. The state also placed an inspector at the site to observe operations and to independently validate compliance of incoming shipments with regulatory requirements. In April 1981, a third-party inspection system of all generators shipping to Beatty was initiated and required. Under the inspection system, which was conducted by a contractor to the state, permits were issued only after an initial audit had been performed to verify the generator's compliance with federal and state regulations and the disposal facility license requirements. The inspection contractor also performed unannounced follow-up audits of the permitted generator.

\section{Closure}

US Ecology submitted to the State of Nevada a proposed site stabilization and closure plan for the LLW facility which provides for post-closure monitoring. The state has reviewed and approved the closure plan, and US Ecology began implementation in November 1993. As of early 1996, the site is in a post-closure and observation phase.

\section{SITE}

\section{Topography}

The Beatty site is approximately $17.7 \mathrm{~km}(11 \mathrm{mi})$ south of the town of Beatty, and $169 \mathrm{~km}$ (105 mi) northwest of Las Vegas (Figure 4-1). The Amargosa Desert region is part of the Basin and Range Province, which is characterized by relatively barren mountain ranges and broad, relatively flat, sparsely vegetated valleys.

\section{Climate}

The site is situated in one of the most arid parts of the United States. Mean annual precipitation is about $11.4 \mathrm{~cm}(4.5 \mathrm{in}$.) at Beatty and $7.4 \mathrm{~cm}(3 \mathrm{in}$.) at Lathrop Wells. Most of the precipitation falls during the winter months as rain. Snow is uncommon at Beatty and it persists on the ground for no more than a few hours. Summer rainfall occurs predominantly during convective storms that may yield 
intense rainfall over small areas. On several occasions during late August or in September, tropical storms have come inland from the Pacific Ocean, crossing the California coast between San Diego and Los Angeles, and moved northeast across southern Nevada. Such a storm, in August 1977, produced nearly $5 \mathrm{~cm}$ ( $2 \mathrm{in}$.) of rain in 24 hours at Beatty. During 1981 through 1988, an annual average of $12.4 \mathrm{~cm}$ (4.9 in.) of precipitation, ranging from as little as $4.4 \mathrm{~cm}(1.73 \mathrm{in}$.) in 1985 to as much as $22.5 \mathrm{~cm}$ (8.9 in.) in 1983, was recorded at the waste disposal facility. Estimated mean annual potential evaporation at Beatty is about $190 \mathrm{~cm}(75.0 \mathrm{in}$.). Seasonal variation in potential evaporation ranges from $4.0 \mathrm{~cm}$ (1.58 in.) in December to $33.0 \mathrm{~cm}(13 \mathrm{in}$.) in July. There are no perennial streams within about $16 \mathrm{~km}(10 \mathrm{mi})$ of the site.

The temperature distribution and ranges at Lathrop Wells are similar to those at Beatty. The mean annual maximum daily temperature for the period $1949-79$ is $25^{\circ} \mathrm{C}\left(77^{\circ} \mathrm{F}\right)$. The mean annual minimum daily temperature is $6^{\circ} \mathrm{C}\left(42.8^{\circ} \mathrm{F}\right)$, and the mean annual daily temperature is $15^{\circ} \mathrm{C}\left(59^{\circ} \mathrm{F}\right)$. The mean daily maximum temperature exceeds $32^{\circ} \mathrm{C}\left(89.6^{\circ} \mathrm{F}\right)$ from June through September. The hottest month is July, with a mean daily maximum temperature of $37^{\circ} \mathrm{C}\left(98.6^{\circ} \mathrm{F}\right)$; the mean daily minimum temperature for this month is $18^{\circ} \mathrm{C}\left(64.4^{\circ} \mathrm{F}\right)$. Average daily minimum temperatures fall below $0^{\circ} \mathrm{C}\left(32^{\circ} \mathrm{F}\right)$ during December, January, and February. The coldest month is January, with a mean daily minimum temperature of $-3^{\circ} \mathrm{C}\left(26.6^{\circ} \mathrm{F}\right)$; several days in early January have long-term mean daily minimum temperatures below $-5^{\circ} \mathrm{C}\left(23^{\circ} \mathrm{F}\right)$.

\section{Land Use}

The US Ecology facility is located in Nye County, Nevada, approximately $19.2 \mathrm{~km}$ (12 mi) southeast of the town of Beatty, in the Amargosa Desert. The facility is located approximately $48 \mathrm{~km}$ (30 mi) northwest of the town of Lathrop Wells and $9.7 \mathrm{~km}(6 \mathrm{mi})$ west of the Nevada Test Site. Land in the area is owned by the U.S. Government and is managed by the Bureau of Land Management.

The buffer zone between the 0.34 square kilometer ( 80 acre) LLWF/HWMF and the federally owned land is approximately $402 \mathrm{~m}(1320 \mathrm{ft})$ wide.

As the facility is located in a desert, there are no business, recreational, or residential activities conducted in the area adjacent to the facility. The region is maintained as open range land with occasional mineral extraction activities. A gold mine is operated approximately $6.4 \mathrm{~km}(4 \mathrm{mi})$ west of the town of Beatty. The town of Beatty is also located approximately $9.6 \mathrm{~km}(6 \mathrm{mi})$ east of the northern entrance to Death Valley National Park. As a result, the town experiences some tourist trade.

\section{Geology}

The site is located on unconsolidated deposits of alluvial sand, clay, silt, and gravel approximately $183 \mathrm{~m}$ (600 ft) thick, formed by weathering action on the adjacent mountain ranges (Figure 4-5). Underlain by folded metamorphic and sedimentary bedrock, the site surface is approximately $854 \mathrm{~m}$ $(2,800 \mathrm{ft})$ above sea level. A regional ground water table lies at a depth of 79 to $101 \mathrm{~m} \mathrm{(260} \mathrm{to} 330 \mathrm{ft})$ below the surface in the alluvial soils. 


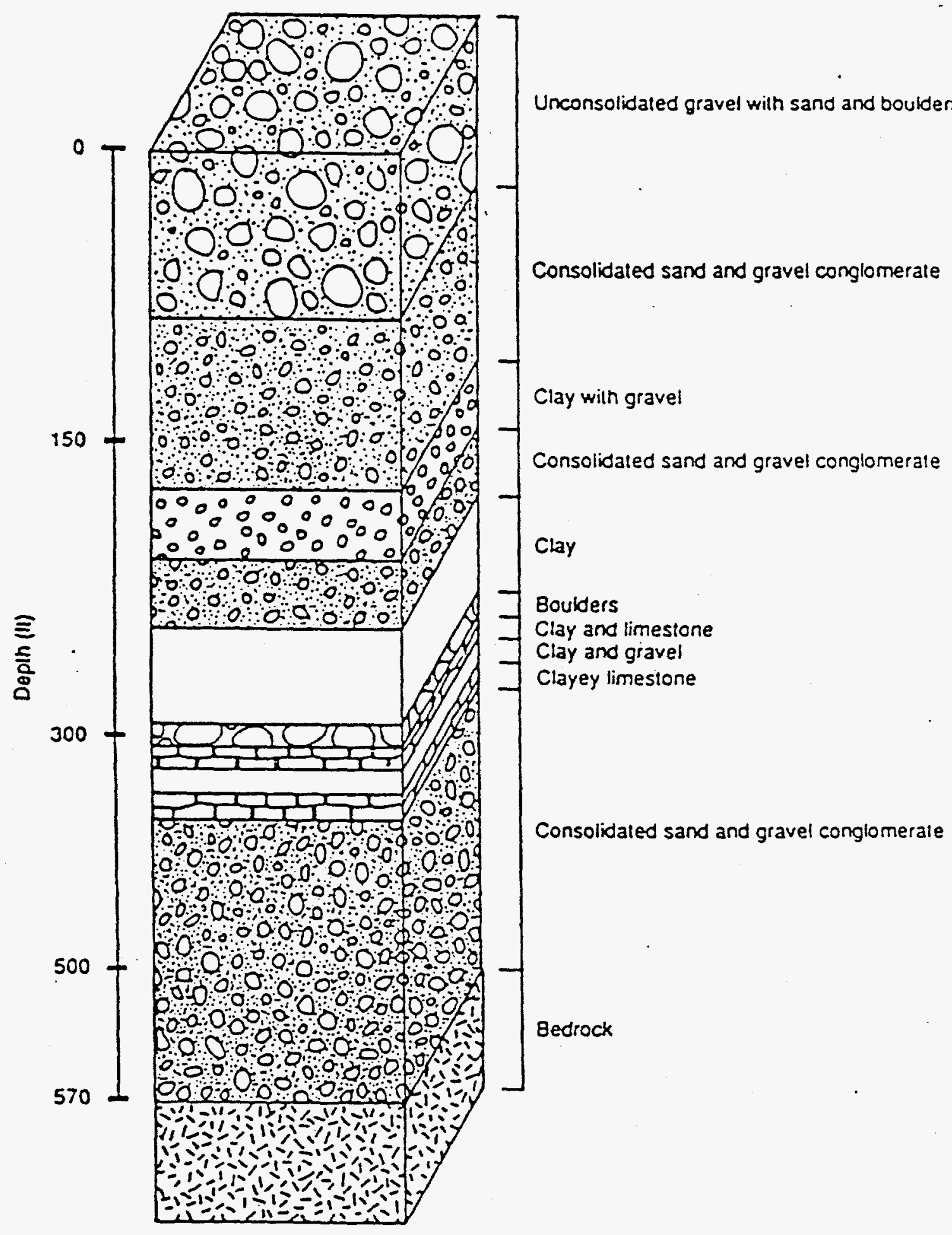

Figure 4-5. Site geology of the Beatty LLW site. 
The Amargosa Desert is bounded, in large part, by mountain ranges composed of lower Paleozoic carbonate and clastic sedimentary and metasedimentary rocks. The valley floor is presumably underlain at depth by rocks of these same types. Tertiary volcanic rocks also occur in several of the ridges between the southern end of Bare Mountain and Lathrop Wells on the east side of the valley.

The geologic structure of the region surrounding the Amargosa Desert is complex. The major structural features include large-scale normal and thrust faults. Many of the surrounding mountain ranges are bounded by normal faults producing the typical Basin-and-Range structure shown by the topography of the area. Within the surrounding ranges, the rocks are folded and for the most part intensely faulted by small-scale thrust, tear, normal, and strike-slip faults. Superimposed on this highly complex pattern of folding and faulting are several shear zones including the Las Vegas Valley shear zone which extends northwestward to Mercury, Nevada, just south of the Amargosa Desert, and shear zones in Death Valley and the Amargosa Desert.

\section{Surface Water}

The intermittently flowing Amargosa River is $8 \mathrm{~km}(5 \mathrm{mi})$ from the site and is the principal drainage channel in the area. No source of perennial water is found within $16.1 \mathrm{~km}(10 \mathrm{mi})$ of the site (Figure 4-1). Precipitation is sparse in the area, averaging less than $10 \mathrm{~cm} \mathrm{(4} \mathrm{in.)} \mathrm{a} \mathrm{year,} \mathrm{but} \mathrm{surface}$ runoff is even more rare. The dry channel of the Amargosa passes about $3 \mathrm{~km}(1.86 \mathrm{mi})$ west of the waste burial site.

The waste burial site is located in the drainage basin of the Amargosa River which is part of the Death Valley hydrographic area. The terminus of the dry channel of the Amargosa River is at the southern end of Death Valley, but no flow has been observed along that part of the river in historic times..$^{4-1}$

\section{Ground Water}

Few wells have been drilled in the northern Amargosa Desert and, consequently, knowledge of the ground water system beneath the area is poorly known.

Knowledge of the ground water system beneath the waste burial site is based almost solely on the information obtained from the drilling and testing of a well at the waste burial site in 1961 . The data obtained from this well suggests the presence of a principal water bearing zone in the valley-fill deposits in the depth interval from 99 to $103 \mathrm{~m} \mathrm{(325} \mathrm{to} 338 \mathrm{ft}$ ) below land surface. Another, less productive zone exists from 132 to $173 \mathrm{~m}$ ( 433 to $568 \mathrm{ft}$ ). This zone may be in hydraulic continuity with the water-bearing bedrock aquifer that is presumed to underlie the valley fill. Depth to water beneath the waste burial facility is approximately $85 \mathrm{~m}(280 \mathrm{ft})$.

The ground water system beneath the site eventually terminates in Death Valley. 


\section{Ecology}

Perennial plant species that occur in the vicinity of the Beatty site include: Larrea tridentata (creosote bush), Ambrosia dumosa (bur-sage or burro bush), Krameria parvifolia (range ratanyl), Acamptopappus shockleyi (goldenhead), Atriplex confertifolia (shadscale), Atriplex canescens (four-winged salt bush), Ephedra nevadensis (mormon tea), Lycium andersonii (desert thorn or wolfberry), and Lycium pallidum (box-thorn).

Winter and early spring rains are more important for growth than the local, infrequent summer rains. As soil moisture is depleted and soil temperatures rise in the summer, some species start to lose their leaves and become dormant. Some species also can have a dormancy period in the winter. Shrub species that never shed all their leaves and are therefore considered evergreens and are able to grow after spring, summer, or fall rains include Larrea tridentata and the Atriplex species. The Larrea tridentata vegetational grouping contains 23 species. The Larrea tridentata grouping is the most widespread and diversified, and is considered the most stable vegetation cover in this area and consequently represents a climax community. The soil surface itself is structured into highly and poorly productive areas which is of major importance to the maintenance of perennial desert ecosystems.

Wildlife is dominated by rodents. These include Thomomys bottae (pocket gophers), Lepus californicus and Sylvilagus audobonii (rabbits), Dipodomys merriami (kangaroo rats), and Onychomys torridus and Peromyscus spp. (mice).

\section{ENVIRONMENTAL MONITORING}

\section{Overview}

Environmental monitoring at the Beatty LLW facility is performed to demonstrate compliance with federal, state, and local regulations; to confirm adherence to environmental protection policies; and to support the environmental management decisions. These regulations require that effluents to the general environment be maintained as low as reasonably achievable (ALARA) and that annual doses due to effluents not exceed 0.25 millisieverts ( 25 millirems) to the whole body, 0.75 millisieverts (75 millirems) to the thyroid, and 0.25 millisieverts ( 25 millirems) to any other organ of any member of the public.

The major goals of the environmental radiation program are to identify, assess and initiate appropriate corrective actions needed to prevent any potential exposure to the public or contamination of the environment before a significant problem develops. The program is designed to evaluate radioactivity levels in the environment over a period of time, both to assess compliance with appropriate standards and to determine trends. Trend analysis is necessary to identify a potential problem and to initiate corrective action to reverse the trend.

Environmental monitoring started in May 1961 prior to site operations. Soil and vegetation samples were taken from the vicinity of the four facility corners. Ground water sampling from the on- 
site well started in October 1962. Monitoring locations and the analysis performed on environmental samples were modified from time to time over the 30 years of operations.

Environmental monitoring included radioanalysis of ground water, air particulates, air tritium, surface soil, vegetation, and ambient gamma measurements using thermoluminescent dosimeters (TLDs). Monitoring of the LLW disposal facility is conducted on-site by the site operator, US Ecology, Inc. The Nevada Radiological Health Section conducts independent monitoring on-site and off-site, with all samples analyzed by a contract laboratory. The samples are scanned for gammaemitters and analyzed for gross alpha and gross beta activity.

Action levels for gross alpha and gross beta in soil and vegetation were established by the State of Nevada in 1977. These are shown in Table 4-2.

Gross alpha, gross beta, and hazardous constituent data obtained from monitoring of the adjacent chemical waste disposal site are also reviewed by the Nevada Radiological Health Section.

\section{Ground Water}

The Beatty Site Well (a specific well) was completed on July 17, 1961, and has a $175 \mathrm{~m}$ (575 ft) boring with the screened area starting at $84 \mathrm{~m}(275 \mathrm{ft})$ from the bottom. Beginning in the fourth quarter of 1962, the Beatty site well was analyzed for gross alpha, gross beta and, beginning in January 1972, for tritium concentration. From 1962 through 1972, only the on-site well was sampled. In the third quarter of 1982, sampling from two new wells-an upgradient well (\#301) and a downgradient well (\#302)-was started (Figure 4-4).

The results of the gross alpha, gross beta and tritium concentration in ground water samples are listed in Table 4-3 and Figures 4-6, 4-7, and 4-8. The mean concentration of gross alpha and beta in the Beatty Site Well samples from 1962 to 1972 were $0.22 \mathrm{~Bq} / \mathrm{L}$ and $0.92 \mathrm{~Bq} / \mathrm{L}(5.9$ and $24.8 \mathrm{pCi} / \mathrm{L}$ )

Table 4-2. Action levels for gross alpha and gross beta in soil, vegetation, ${ }^{a}$ and ground water (including tritium in ground water only).

\begin{tabular}{llll}
\hline Material & Gross Alpha & Gross Beta & Tritium \\
\hline Soil & $1.11 \mathrm{~Bq} / \mathrm{gm}$ & $3.33 \mathrm{~Bq} / \mathrm{gm}$ & \\
& $(30.0 \mathrm{pCi} / \mathrm{gm})$ & $(90.0 \mathrm{pCi} / \mathrm{gm})$ & \\
Vegetation & $0.74 \mathrm{~Bq} / \mathrm{gm}$ & $7.4 \mathrm{~Bq} / \mathrm{gm}$ & \\
& $(20.0 \mathrm{pCi} / \mathrm{gm})$ & $(200.0 \mathrm{pCi} / \mathrm{gm})$ & \\
Ground water & $1.11 \mathrm{~Bq} / \mathrm{L}$ & $3.3 \mathrm{~Bq} / \mathrm{L}$ & $74 \mathrm{~Bq} / \mathrm{L}$ \\
& $(30.0 \mathrm{pCi} / \mathrm{L})$ & $(90 \mathrm{pCi} / \mathrm{L})$ & $(2,000 \mathrm{pCi} / \mathrm{L})$ \\
& & & \\
& & & \\
\hline
\end{tabular}


Table 4-3. Gross alpha, gross beta, and tritium activity in ground water.

\begin{tabular}{|c|c|c|c|}
\hline Year & $\begin{array}{c}\text { Gross alpha }^{\mathrm{a}} \\
\mathrm{pCi} / \mathrm{L}\end{array}$ & $\begin{array}{c}\text { Gross beta }^{\mathrm{a}} \\
\mathrm{pCi} / \mathrm{L}\end{array}$ & $\begin{array}{c}\text { Tritium } \\
\mathrm{pCi} / \mathrm{L}\end{array}$ \\
\hline 1962 & $3 \pm 2$ & $54 \pm 4$ & No data \\
\hline 1963 & No data & No data & No data \\
\hline 1964 & $8 \pm 3$ & $50 \pm 26$ & No data \\
\hline 1965 & $20 \pm 5$ & $60 \pm 31$ & No data \\
\hline 1966 & $10 \pm 5$ & $60 \pm 34$ & No data \\
\hline 1967 & $10 \pm 4$ & $40 \pm 28$ & No data \\
\hline 1968 & $14 \pm 5$ & $52 \pm 3$ & No data \\
\hline 1969 & $6 \pm 3$ & $41 \pm 41$ & No data \\
\hline 1970 & $39 \pm 7$ & $94 \pm 30$ & No data \\
\hline 1971 & No data & No data & No data \\
\hline 1972 & $10 \pm 4$ & $9 \pm 4$ & No data \\
\hline 1973 & $46 \pm 7$ & $549 \pm 47$ & No data \\
\hline 1974 & $16 \pm 10$ & $132 \pm 77$ & No data \\
\hline 1975 & $47 \pm 9$ & $173 \pm 55$ & No data \\
\hline 1976 & $12 \pm 5$ & $40 \pm 32$ & No data \\
\hline 1977 & $<3$ & $<30$ & No data \\
\hline 1978 & $3 \pm 2$ & $<20$ & No data \\
\hline 1979 & $10 \pm 5$ & $<20$ & $3,800 \pm 1,100$ \\
\hline 1980 & $<5$ & $10 \pm 4$ & $1,700 \pm 900$ \\
\hline 1981 & $21 \pm 7$ & $31 \pm 4$ & 0 \\
\hline 1982 & $710 \pm 183$ & $340 \pm 49$ & $24,000 \pm 1,000$ \\
\hline 1983 & $140 \pm 98$ & $930 \pm 150$ & $49,000 \pm 29,000$ \\
\hline 1984 & $63 \pm 29$ & $140 \pm 24$ & $5,000 \pm 4,000$ \\
\hline 1985 & $25 \pm 18$ & $26 \pm 10$ & $1,100 \pm 600$ \\
\hline 1986 & $15 \pm 9$ & $14 \pm 5$ & $<500$ \\
\hline 1987 & No data & No data & No data \\
\hline 1988 & $31 \pm 11$ & $10 \pm 3$ & $<500$ \\
\hline 1989 & $20 \pm 14$ & $30 \pm 23$ & $1,548 \pm 508$ \\
\hline 1990 & $78 \pm 24$ & $63 \pm 11$ & $<500$ \\
\hline 1991 & $10 \pm 6$ & $11 \pm 5$ & $1,079 \pm 551$ \\
\hline 1992 & $7 \pm 3$ & $13 \pm 3$ & $<500$ \\
\hline
\end{tabular}

Action Levels: gross alpha $=30.0 \mathrm{pCi} / \mathrm{L}$; gross beta $=90.0 \mathrm{pCi} / \mathrm{L} ;$ tritium $=2,000 \mathrm{pCi} / 1$.

a. Indicates highest value for each year. 

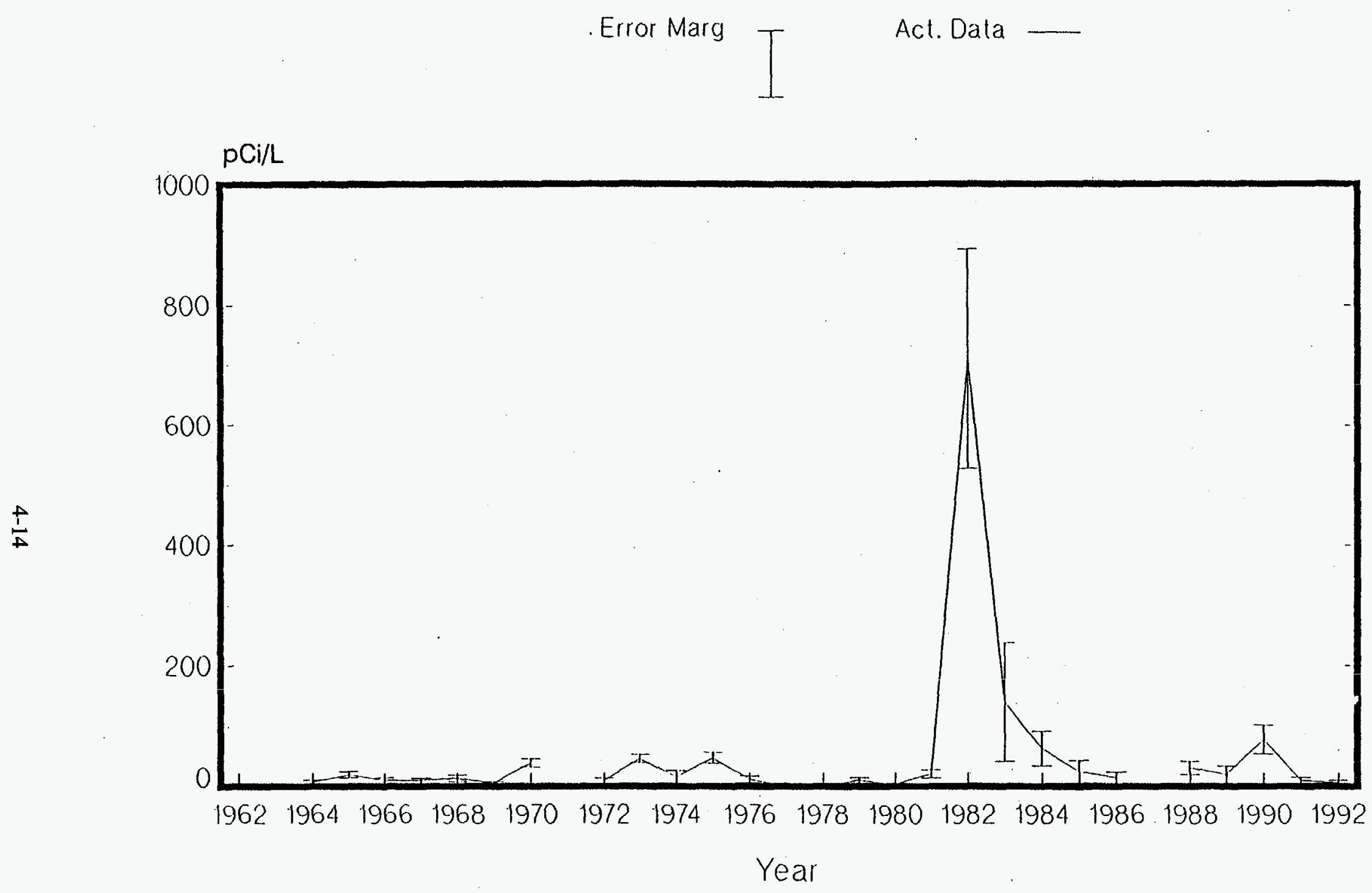

Maximum Values For Each Year (Action Level $=30 \mathrm{pCi} / \mathrm{L}$ )

Figure 4-6. Gross alpha groundwater samples: Beatty, Nevada. 


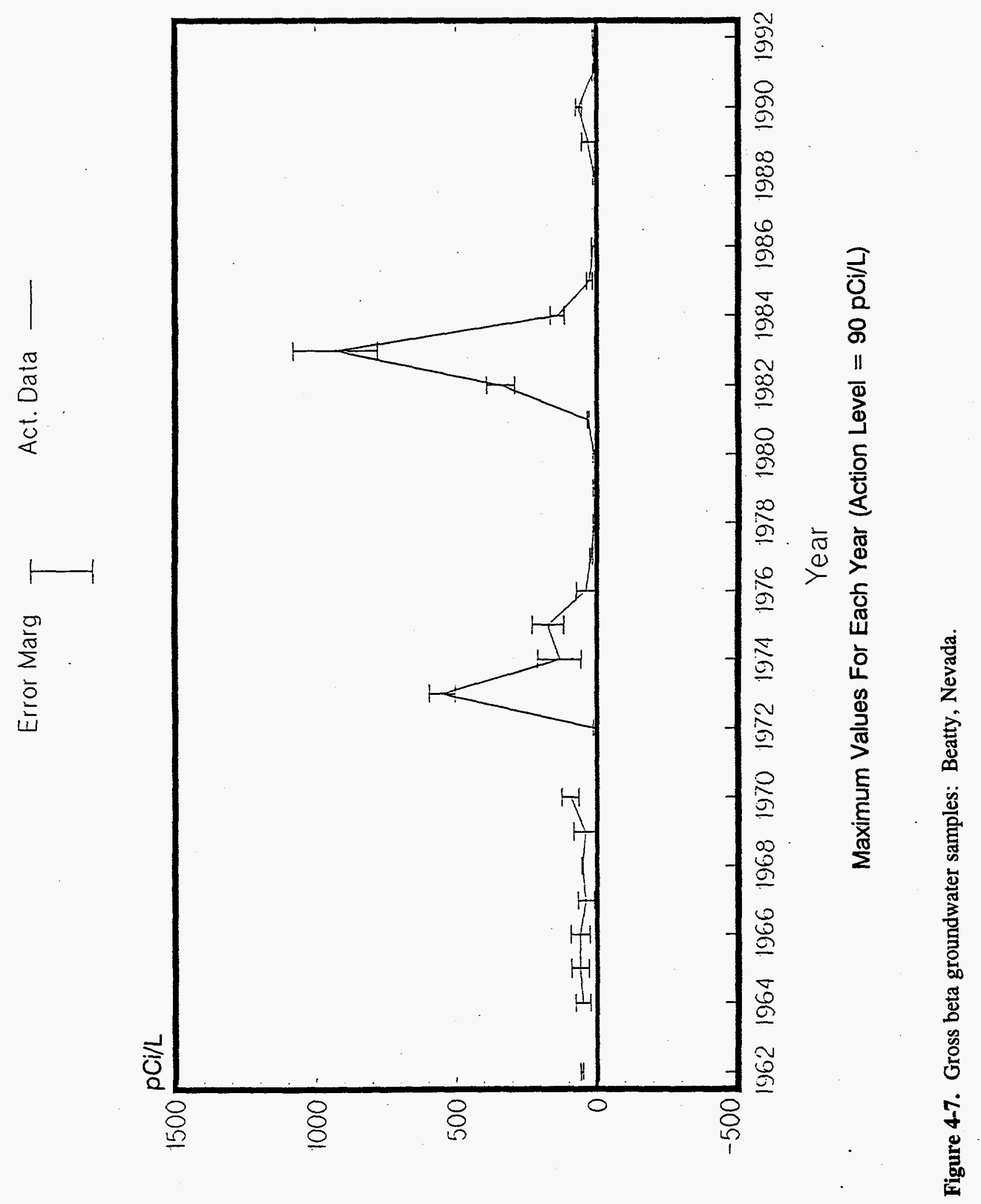




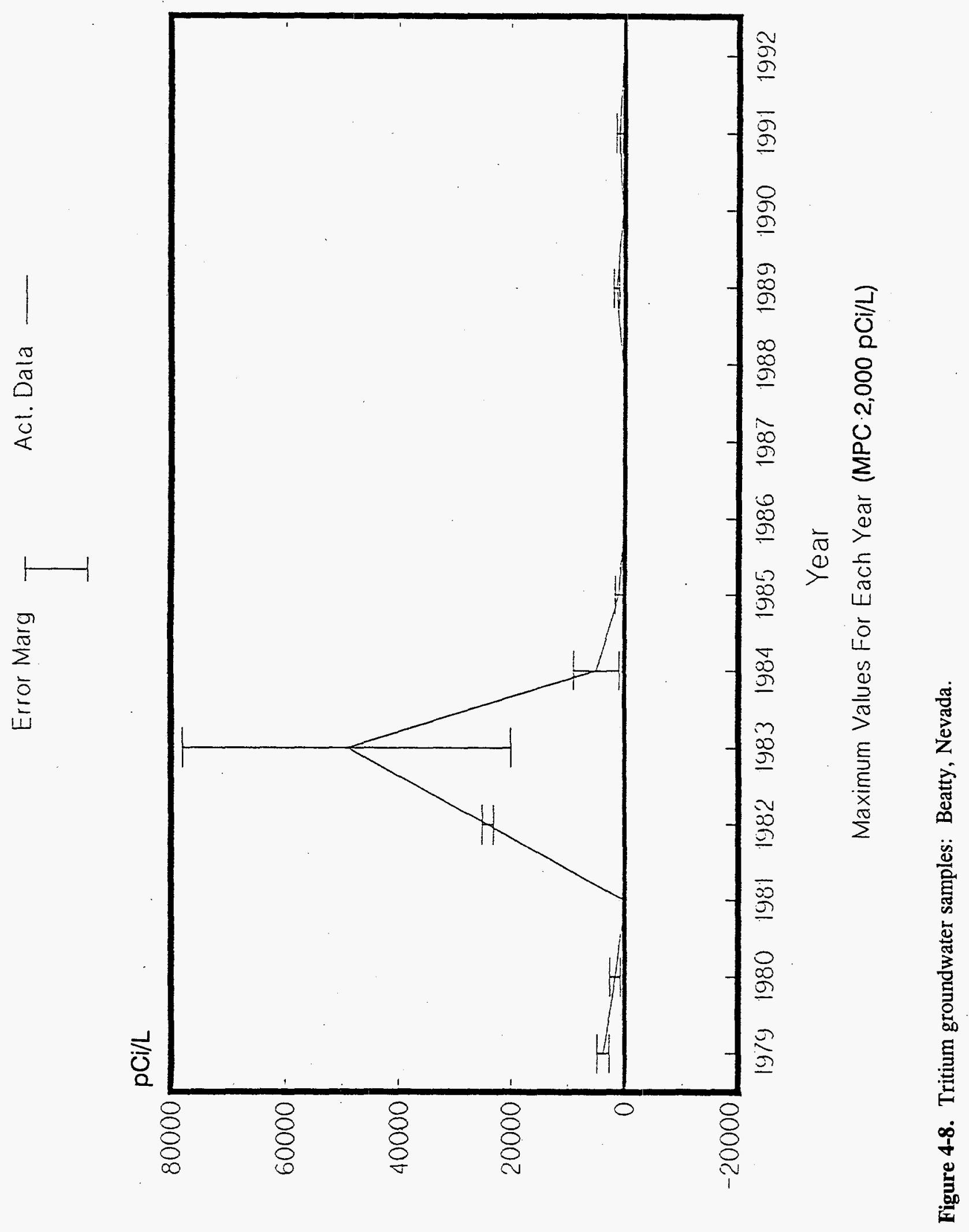


respectively. The gross alpha concentration varied from less than detectable to $0.74 \mathrm{~Bq} / \mathrm{L}(20 \mathrm{pCi} / \mathrm{L})$ for a December 1965 sample. The gross beta concentration varied from less than detectable to 3.5 Bq/L (94 pCi/L) in July 1970 . The trend during these years was a reduction in both the gross alpha and beta concentration, most likely due to changes in the instrumentation and methodology used by the vendor laboratories.

In 1974, water from the Lathrop Wells was used as a control or background comparison to the site wells sample analysis. In 1979, analysis for tritium was performed on all ground water samples. From 1974 until September 1982, there was no significant difference between the concentration of gross alpha, gross beta and tritium in any of the ground water samples. ${ }^{4-2}$

A review of the analysis results for tritium in ground water (Table 4-3 and Figure 4-8) indicate that for most years the tritium activity has been below the action level of $74 \mathrm{~Bq} / \mathrm{L}(2000 \mathrm{pCi} / \mathrm{L})$. The exceptions have been the years $1979,1982,1983$, and 1984, when the tritium concentration exceeded the action levels and showed activities as high as $15,170 \pm 370 \mathrm{~Bq} / \mathrm{L}(410,000 \pm 10,000 \mathrm{pCi} / \mathrm{L})$ during 1982 (not included in Table 4-3 or Figure 4-8) for the downgradient well \#302. These abnormally high values are still well below the federal regulatory limits for tritium in water for both restricted areas (0.41\% 10 CFR 20 values) and unrestricted areas (13.7\% 10 CFR 20 values). ${ }^{42}$

After 1984, a gradual reduction in the concentration occurred. The results of ground water samples of Well 302 since February 1986 have been less than the minimum detection limits, $18.5 \mathrm{~Bq} / \mathrm{L}$ $(500 \mathrm{pCi} / \mathrm{L})$.

Subsequent to the detection of tritium in Wells 301 and 302, the monitoring frequency was increased. Sampling was increased from quarterly to monthly and during 1983 it went to bi-weekly. Ground water samples were evaluated by analyzing both the dissolved and suspended fraction. The sediments in the ground water were analyzed using gamma spectroscopy and fluoroscopy to evaluate whether non-natural radionuclides were contributing to the gross alpha and beta concentrations. Sediments from Well \#301 were positive for Co-60 in a May 1985 sample at $0.1 \pm .02 \mathrm{~Bq} / \mathrm{L}(2.7 \pm$ $0.6 \mathrm{pCi} / \mathrm{L}$ ). All other elevated gross alpha and beta concentrations were shown to be due to $\mathrm{K}-40$, natural uranium and its decay products, and natural thorium and its decay products.

The maximum tritium concentrations in Well 302 were less than $14 \%$ of the allowed concentration listed in the Nevada Administrative Code, Section 459.334, Table of Concentrations in Air and Water Above Background, Table II, Column 2.4-2

Since the July 1984 sample, there have been only two positive tritium samples, both from Well 302. The gross alpha, beta, and tritium concentrations in the ground water samples have not varied significantly between sample locations. An upward trend has been identified in the gross beta concentration since the second quarter of 1980 , which is most likely due to a reduction in the minimum detectable concentration of gross beta activity in water. The gross beta concentration increased and then remained constant with no significant difference between the three sampling locations.

Analysis demonstrated that the gross alpha, gross beta, and tritium concentrations were seldom greater than the minimum detectable concentration. ${ }^{4-2}$ 


\title{
Surface Water
}

The intermittently flowing Amargosa River is $8 \mathrm{~km}(5 \mathrm{mi})$ from the site and is the principal drainage channel in the area. No source of perennial water is found within $16.1 \mathrm{~km}(10 \mathrm{mi})$ of the site, and therefore no surface water monitoring has been conducted.

\begin{abstract}
Air
The continuous air monitoring program was instituted in June 1989. Air sampling was performed at the three monitoring points (Figure 4-3) to determine the concentration of airborne tritium and air particulate.

Tritium was sampled using a silica gel cartridge which was changed on a monthly basis in order to allow for the collection of a sufficient amount of moisture in the silica gel column. Results of tritium concentration in air (1989-1992) are provided in Table 4-4. None of the values exceeded the action level of $7.4 \mathrm{E}-4 \mathrm{~Bq} / \mathrm{cc}(2.0 \mathrm{E}-8 \mu \mathrm{Ci} / \mathrm{cc})$. $^{4-3,4-4,45,4-6,47}$

Air particulate sampling was performed at the same three locations as tritium sampling (Figure 4-3). Filters were analyzed for gross alpha and gross beta concentration on an approximately weekly basis. Results of this analysis ${ }^{44,47}$ showed that the concentrations of gross alpha and gross beta in air particulate samples were below the action levels of $1.9 \mathrm{E}-9$ and $1.1 \mathrm{E}-5 \mathrm{~Bq} / \mathrm{cc}(5 \mathrm{E}-13 \mu \mathrm{Ci} / \mathrm{cc}$ and $3.0 \mathrm{E}-9 \mu \mathrm{Ci} / \mathrm{cc}$ ) for gross alpha and beta, respectively.
\end{abstract}

\section{Soil}

Regular soil sampling started in December 1963. Soil samples were originally taken from dry wells located near the disposal trenches and the vicinity of the four corners of the disposal site. The dry wells were constructed in order to intersect any potential subsurface migration from completed trenches. Dry wells were normally located at the south side of the completed trenches and extended to a minimum of $3.0 \mathrm{~m} \mathrm{(10} \mathrm{ft)} \mathrm{below} \mathrm{the} \mathrm{established} \mathrm{bottom} \mathrm{of} \mathrm{the} \mathrm{trench.} \mathrm{In} \mathrm{addition} \mathrm{to} \mathrm{the} \mathrm{dry} \mathrm{wells}$ associated with each completed burial trench, two dry wells were located south of the site. The sample medium in all of the dry wells is the soil at the bottom. Surface soil samples were also taken from locations outside the licensed disposal area. The soil samples taken outside the site are located Table 4-4. Tritium activity in air $(\mu \mathrm{Ci} / \mathrm{cc}){ }^{\mathrm{a}}$

$\begin{array}{ll}1989 & 0.92 \pm 0.75 \mathrm{E}-10 \\ 1990 & 4.50 \pm 0.50 \mathrm{E}-10 \\ 1991 & 8.70 \pm 0.75 \mathrm{E}-10 \\ 1992 & 1.56 \pm 0.50 \mathrm{E}-10\end{array}$

Action level of tritium in air $=2.0 \mathrm{E}-8 \mu \mathrm{Ci} / \mathrm{cc}$

a. Indicates the highest value for each year. 
approximately $61 \mathrm{~m}$ (200 ft) from the fenced disposal area, to the north, southeast, east, and west. These areas are identified by markers in the ground to ensure sample reproductivity. Samples are

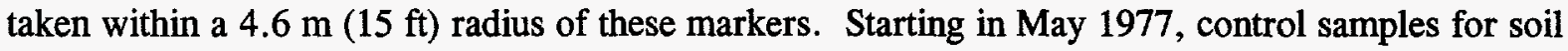
were taken from the Lathrop Wells area. The Lathrop Wells area has similar flora and geologic formations to the Beatty LLW disposal facility.

By 1977, the soil sampling locations had become standardized and consisted of 19 sampling areas. Soil samples were taken quarterly and analyzed for gross alpha and beta. Occasionally, additional locations were sampled. The primary soil sampling locations included:

- The control sample from Lathrop Wells

- Dry wash $305 \mathrm{~m}(1,000 \mathrm{ft})$ southeast of LLW disposal site

- $\quad$ Office area

- West Quadrant $61 \mathrm{~m}(200 \mathrm{ft})$ outside the fence

- North Quadrant $61 \mathrm{~m}(200 \mathrm{ft})$ outside the fence

- $\quad$ East Quadrant $61 \mathrm{~m}(200 \mathrm{ft})$ outside the fence

- Dry Wells R-1 through R-6, R-14, R-16, R-19, P-1, P-3, and P-4.

Surface soil samples were taken from undisturbed areas, using a ring of approximately $10 \mathrm{~cm}$ (4 in.) inside diameter, pressed into the soil $5 \mathrm{~cm}(2 \mathrm{in}$.) deep. Dry wells were sampled by pouring approximately $500 \mathrm{ml}$ of clean tap water or, after 1983, deionized water in the dry well; and after approximately a three-hour wait, a sample collection tube was allowed to free-fall down the dry well to compact a sample into the tube.

The soil samples were analyzed for gross alpha and beta concentrations. Action levels were established in 1977 and were $1.1 \mathrm{~Bq} / \mathrm{gm}$ (30 pCi/gm) for gross alpha and $3.3 \mathrm{~Bq} / \mathrm{gm}(90 \mathrm{pCi} / \mathrm{gm})$ for gross beta concentrations. When action levels were exceeded, the State of Nevada representative was notified and a gamma spectrum analysis was performed on the sample. Radioanalysis results of gross alpha, gross beta, and gamma spectrometry in soil samples are provided in Tables 4-5 and 4-6, respectively. Graphical presentations of gross alpha and gross beta are shown in Figures 4-9 and 4-10, respectively.

In September 1984, the State of Nevada deleted the requirement for soil sampling of the dry wells. Dry well soil sampling was discontinued because most of the soil had been removed from the dry wells during the years of sampling and only rocks were present in the bottom of many of the wells making it no longer possible to extract a representative soil sample.

The analysis of the dry well soil samples during the previous seven year period never resulted in a concentration exceeding the established action levels. 
Table 4-5. Soil sample analysis-Beatty LLW Site.

\begin{tabular}{|c|c|c|}
\hline Year & $\begin{array}{c}\text { Gross alpha } \\
\mathrm{pCi} / \mathrm{gm}\end{array}$ & $\begin{array}{c}\text { Gross beta } \\
\text { pCi/gm }\end{array}$ \\
\hline 1962 & No data & No data \\
\hline 1963 & No data & No data \\
\hline 1964 & No data & No data \\
\hline 1965 & $1.9 \pm 0.63$ & $72 \pm 4.4$ \\
\hline 1966 & $2.7 \pm 1.2$ & $73 \pm 5.3$ \\
\hline 1967 & $1.7 \pm 0.64$ & $3.5 \pm 0.34$ \\
\hline 1968 & $2.94 \pm 0.41$ & $5.03 \pm 0.57$ \\
\hline 1969 & $9.5 \pm 3.7$ & $37 \pm 4.1$ \\
\hline 1970 & No data & No data \\
\hline 1971 & $8.9 \pm 3.8$ & $80 \pm 4.9$ \\
\hline 1972 & $13 \pm 5$ & $108 \pm 32$ \\
\hline 1973 & $6 \pm 3$ & $110 \pm 40$ \\
\hline 1974 & $18.2 \pm 8.2$ & $253.6 \pm 111$ \\
\hline 1975 & $64 \pm 15$ & $614 \pm 60$ \\
\hline 1976 & $42 \pm 7.7$ & $257 \pm 28$ \\
\hline 1977 & $20 \pm 6.1$ & $60 \pm 24$ \\
\hline 1978 & $18 \pm 6$ & $60 \pm 24$ \\
\hline 1979 & $31 \pm 13$ & $80 \pm 31$ \\
\hline 1980 & $23 \pm 6.1$ & $90 \pm 16$ \\
\hline 1981 & $32 \pm 9.8$ & $60 \pm 15$ \\
\hline 1982 & $25 \pm 6$ & $66 \pm 18$ \\
\hline 1983 & $24 \pm 7$ & $79 \pm 4$ \\
\hline 1984 & $25 \pm 7$ & $52 \pm 15$ \\
\hline 1985 & $16 \pm 3$ & $40 \pm 17$ \\
\hline 1986 & $10.2 \pm 1.6$ & $9.6 \pm 1.0$ \\
\hline 1987 & $1.3 \pm 0.3$ & $7.0 \pm 0.8$ \\
\hline 1988 & $5.7 \pm 1.1$ & $6.6 \pm 0.9$ \\
\hline 1989 & $9.3 \pm 2.5$ (wet) & $21.5 \pm 1.3$ (wet) \\
\hline 1990 & $12.8 \pm 3($ dry $)$ & $51.5 \pm 7$ (dry) \\
\hline 1991 & $3.5 \pm 1.0(\mathrm{dry})$ & $22.0 \pm 1.3($ dry $)$ \\
\hline 1992 & $5.4 \pm 2.7(\mathrm{dry})$ & $28.4 \pm 2.3$ (dry) \\
\hline
\end{tabular}

Action Levels: gross alpha $=30.0 \mathrm{pCi} / \mathrm{gm}$; gross beta $=90.0 \mathrm{pCi} / \mathrm{gm}$.

a. Indicates highest value for each year. 
Table 4-6. Gamma spectroscopy analysis of soil samples (pCi/gm) (April 1982). ${ }^{\mathrm{a}}$

\begin{tabular}{|c|c|c|}
\hline Location & Analysis & Concentration \\
\hline $320 \mathrm{ft}$. south of Trench $18,70 \mathrm{ft}$. & $\mathrm{K}-40$ & $26 \pm 0.41$ \\
\hline east of Rad/Buffer Zone, $10 \mathrm{ft}$. & Mn-54 & $0.019 \pm 0.013$ \\
\hline \multirow[t]{4}{*}{ NW sample point } & Cs-137 & $0.29 \pm 0.017$ \\
\hline & $\mathrm{Ra}-226$ & $1.00 \pm 0.076$ \\
\hline & $\mathrm{Ra}-228$ & $2.0 \pm 0.076$ \\
\hline & Th-228 & $1.9 \pm 0.027$ \\
\hline $320 \mathrm{ft}$. south of Trench $18,70 \mathrm{ft}$. & $\mathrm{K}-40$ & $25 \pm 0.4$ \\
\hline east of Rad/Buffer Zone, $10 \mathrm{ft} . \mathrm{SW}$ & $\mathrm{Co}-60$ & $0.02 \pm 0.013$ \\
\hline \multirow[t]{5}{*}{ sample point } & Mn-54 & $0.04 \pm 0.0085$ \\
\hline & Cs-137 & $0.72 \pm 0.021$ \\
\hline & $\mathrm{Ra}-226$ & $1.0 \pm 0.032$ \\
\hline & $\mathrm{Ra}-228$ & $2.0 \pm 0.075$ \\
\hline & Th-228 & $1.9 \pm 0.027$ \\
\hline $320 \mathrm{ft}$. south of Trench $18,70 \mathrm{ft}$. & $\mathrm{K}-40$ & $25 \pm 0.39$ \\
\hline east of Rad/Buffer Zone, $10 \mathrm{ft}$. & $\mathrm{Mn}-54$ & $0.037 \pm 0.007$ \\
\hline \multirow[t]{5}{*}{ NE sample point } & $\mathrm{Co}-60$ & $0.064 \pm 0.014$ \\
\hline & Cs -137 & $0.2 \pm 0.021$ \\
\hline & Ra-226 & $0.95 \pm 0.031$ \\
\hline & $\mathrm{Ra}-228$ & $1.9 \pm 0.07$ \\
\hline & Th-228 & $1.8 \pm 0.025$ \\
\hline $320 \mathrm{ft}$. south of Trench $18,70 \mathrm{ft}$. & $\mathrm{K}-40$ & $26.3 \pm 0.4$ \\
\hline east of Rad/Buffer Zone, $10 \mathrm{ft}$. & $\mathrm{Mn}-54$ & $0.021 \pm 0.01$ \\
\hline \multirow[t]{5}{*}{ NW sample point } & Co-60 & $0.087 \pm 0.015$ \\
\hline & Cs-137 & $0.45 \pm 0.019$ \\
\hline & $\mathrm{Ra}-226$ & $0.99 \pm 0.032$ \\
\hline & Ra-228 & $1.9 \pm 0.072$ \\
\hline & Th-228 & $1.8 \pm 0.026$ \\
\hline
\end{tabular}

a. Data for other years are not available. 


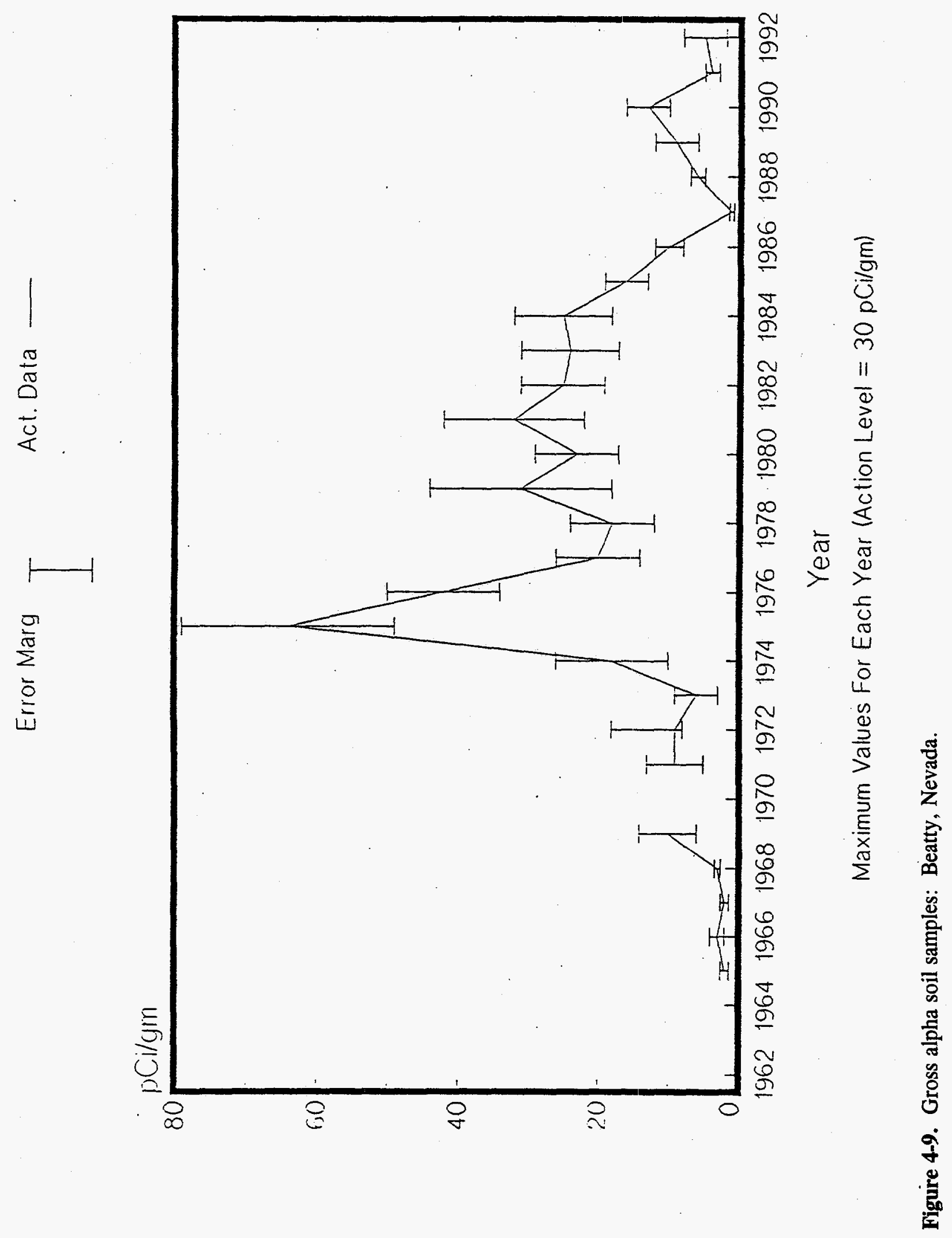



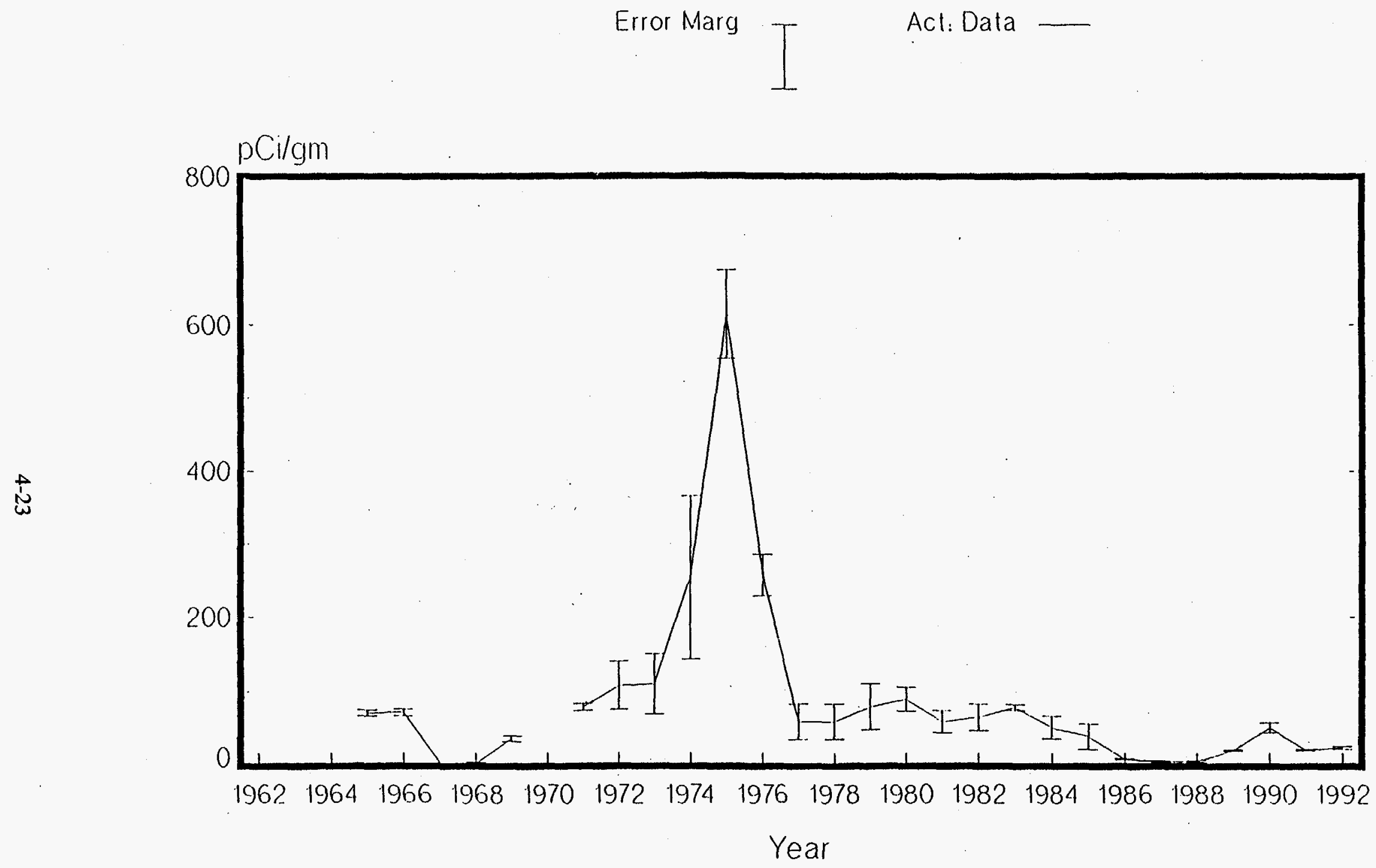

Maximum Values For Each Year (Action level $=90 \mathrm{pCi} / \mathrm{gm}$ )

Figure 4-10. Gross beta soil samples: Beatty, Nevada. 


\section{Biota}

The protocol for the sampling and analysis of vegetation samples parallels that of soil. Vegetation samples were analyzed for gross alpha and beta concentrations beginning in 1961. Sample locations and time periods during which samples were gathered varied substantially from 1961 until 1977. By 1977, samples were being taken quarterly in Lathrop Wells as the control sample, at a dry wash $306 \mathrm{~m}$ $(1,000 \mathrm{ft})$ southeast of the site, in the office area, and at $61 \mathrm{~m}(200 \mathrm{ft})$ outside the north, west, and east quadrants of the site. The results of the radioanalysis of the vegetation samples for gross alpha and gross beta concentration are listed in Table 4-7. Graphical presentations of these data are shown in Figures 4-11 and 4-12.

Vegetation samples consisted of pruned green leafy or foliage material from plants in the sample area. At least 250-300 grams were required for laboratory analysis. Often there was not sufficient green material present, and an analysis could not be performed. Action levels were established in 1977 as $0.74 \mathrm{~Bq} / \mathrm{gm}(20 \mathrm{pCi} / \mathrm{gm}$ ) of dry plant mass for gross alpha contamination and $7.4 \mathrm{~Bq} / \mathrm{gm}$ $(200 \mathrm{pCi} / \mathrm{gm})$ of dry plant mass for gross beta contamination. If an action level was exceeded, the State of Nevada was notified and gamma spectral analysis of the vegetation sample was performed.

Tritium and gamma spectroscopy analyses of vegetation were performed in 1982 from samples collected outside the facility boundary. The results are listed in Table 4-8.

\section{Direct Radiation}

External dose rate monitoring of direct (penetrating) radiation began in 1965. Measurements were performed using film dosimeters placed at the north, east, south, and west fencelines. The film badges were posted quarterly or semiannually and were analyzed by Radiation Detection Company. Monitoring during the early years of operations showed fenceline exposures higher than the monitoring results obtained for later years. During the fourth quarter of 1965 , the west fence film dosimeter read 5.30 millisieverts $(530 \mathrm{mrem})$ and two film dosimeters placed at the north side of the burial ground read 6.80 and 6.40 millisieverts ( 680 and $640 \mathrm{mrem}$ ), the south fence film dosimeter read 12.0 millisieverts ( $1200 \mathrm{mrem}$ ) during the second quarter of 1966 , and the west fence film dosimeter read 4.80 millisieverts ( $480 \mathrm{mrem}$ ) during the second quarter of 1967 . In 1968, the federal government began monitoring the site boundary and a control location at US Highway 95 . Seven locations were monitored on a quarterly basis. Only six measurements since 1968 have exceeded 1.0 millisievert/quarter ( $100 \mathrm{mrem} /$ quarter $)$. The maximum exposure was 11.40 millisieverts $(1,140 \mathrm{mrem})$ at the south fenceline during the third quarter of $1976 .^{4.2}$ The south boundary exposure rates were significantly higher than the other locations. In 1977, in addition to the federal government's monitoring, the facility operator performed area monitoring at 14 locations, using environmental thermoluminescent dosimeters (TLDs). The annual maximum exposures (1977-1992) are listed in Table 4-9, and shown in Figure 4-13. Exposure rates have trended down over the years of operations. The maximum annual exposure was 4.15 millisieverts $(415 \mathrm{mrem})$ at the east boundary in 1978. The south boundary exposure rate remained significantly higher than all other locations. None of the locations exceeded the 1.25 millisieverts/quarter (125 mrem/quarter) action level. 
Table 4-7. Vegetation sample analysis-Beatty LLW Site.

\begin{tabular}{|c|c|c|}
\hline Year & $\begin{array}{c}\text { Gross alpha } \\
\text { pCi/gm }\end{array}$ & $\begin{array}{c}\text { Gross beta } \\
\text { pCi/gm }\end{array}$ \\
\hline 1962 & $0.73 \pm 0.32$ & $126 \pm 3.1$ \\
\hline 1963 & No data & No data \\
\hline 1964 & No data & No data \\
\hline 1965 & $0.13 \pm 0.04$ & $21 \pm 0.5$ \\
\hline 1966 & $0.9 \pm 0.45$ & $110 \pm 5.4$ \\
\hline 1967 & $0.39 \pm 0.22$ & $8.0 \pm 0.4$ \\
\hline 1968 & $0.16 \pm 0.04$ & $13.3 \pm 0.2$ \\
\hline 1969 & $0.17 \pm 0.12$ & $31.3 \pm 0.27$ \\
\hline 1970 & No data & No data \\
\hline 1971 & $0.19 \pm 0.16$ & $2.8 \pm 0.3$ \\
\hline 1972 & $1.4 \pm 1.0$ & $722 \pm 35$ \\
\hline 1973 & $0.36 \pm 0.32$ & $27.2 \pm 3$ \\
\hline 1974 & $3.8 \pm 4.1$ & $420 \pm 110$ \\
\hline 1975 & $3.49 \pm 2.2$ & $146 \pm 30$ \\
\hline 1976 & $9 \pm 3$ & $220 \pm 20$ \\
\hline 1977 & $0.3 \pm 0.006$ & $39.6 \pm 14.5$ \\
\hline 1978 & $0.7 \pm 0.03$ & $36.9 \pm 9$ \\
\hline 1979 & $0.7 \pm 0.6$ & $29.3 \pm 4.2$ \\
\hline 1980 & $2.4 \pm 1$ & $50 \pm 5.1$ \\
\hline 1981 & $9 \pm 4$ & $17.6 \pm 1.4$ \\
\hline 1982 & $2.4 \pm 2$ & $30 \pm 4.9$ \\
\hline 1983 & $6 \pm 3$ & $55.7 \pm 4.9$ \\
\hline 1984 & $6.3 \pm 1.8$ & $15.5 \pm 2.3$ \\
\hline 1985 & $7.2 \pm 1.3$ & $16 \pm 1$ \\
\hline 1986 & $0.8 \pm 0.2$ & $5.8 \pm 0.2$ \\
\hline 1987 & $5.3 \pm 2.7$ & $77.6 \pm 2.5$ \\
\hline 1988 & $3.2 \pm 0.4$ & $10 \pm 0.3$ \\
\hline 1989 & $0.6 \pm 0.2$ (dry) & $65.5 \pm 8.1$ (dry) \\
\hline 1990 & $3.1 \pm 2.4$ (dry) & $16.3 \pm 3.6($ dry $)$ \\
\hline 1991 & $0.5 \pm 0.2$ (dry) & $5.9 \pm 0.3(\mathrm{dry})$ \\
\hline 1992 & $11.4 \pm 2.3($ dry $)$ & $48.9 \pm 2.8$ (dry) \\
\hline
\end{tabular}

Action Levels: gross alpha $=20.0 \mathrm{pCi} / \mathrm{gm}$; gross beta $=200.0 \mathrm{pCi} / \mathrm{gm}$.

a. Indicates highest value for each year. 


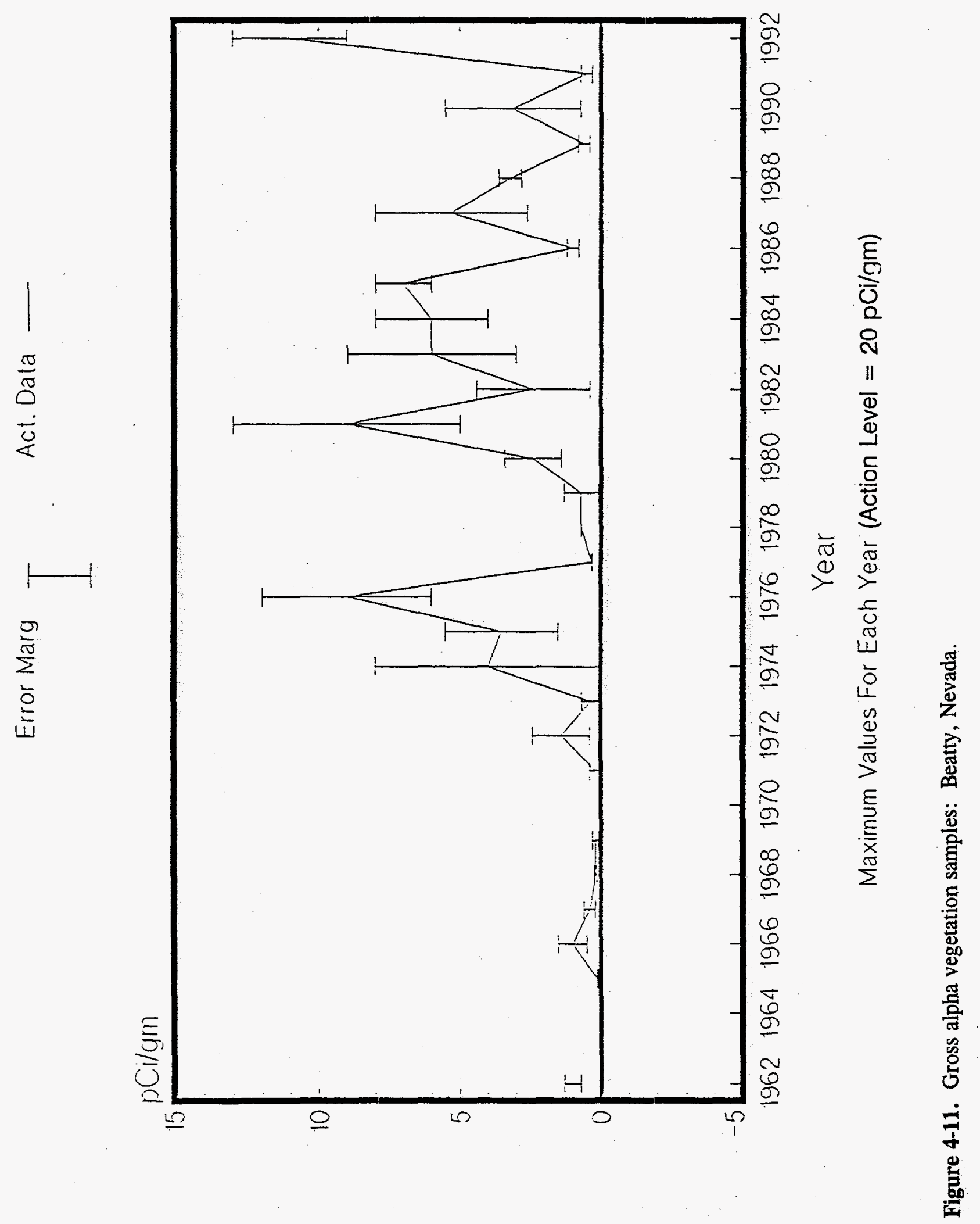




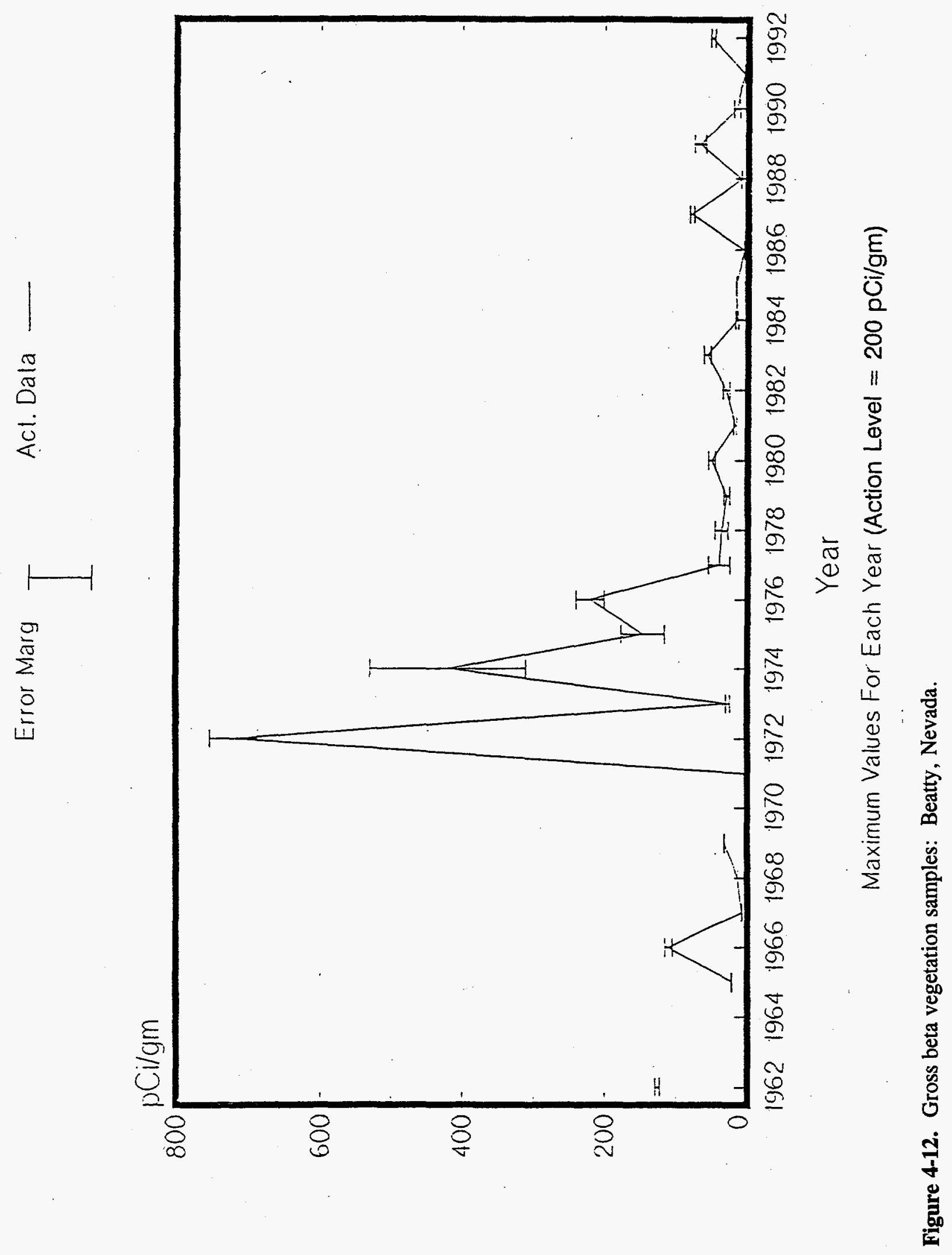


Table 4-8. Tritium and gamma spectroscopy analysis of vegetation samples (March 1982). ${ }^{\mathrm{a}}$

\begin{tabular}{|c|c|c|}
\hline Location & Analysis & Concentration \\
\hline \multirow{2}{*}{$200 \mathrm{ft}$ southeast of south fence in dry wash } & $\mathrm{H}-3$ & $34 \pm 2 \mathrm{pCi} / \mathrm{mL}$ \\
\hline & Cs-137 & $1 \pm 0.4 \mathrm{pCi} / \mathrm{gm}$ \\
\hline \multirow[t]{2}{*}{$240 \mathrm{ft}$ southeast of south fence in dry wash } & $\mathrm{H}-3$ & $1,000 \pm 100 \mathrm{pCi} / \mathrm{mL}$ \\
\hline & Cs-137 & $1.5 \pm 0.6 \mathrm{pCi} / \mathrm{gm}$ \\
\hline \multirow[t]{2}{*}{$300 \mathrm{ft}$ southeast of south fence in dry wash } & $\mathrm{H}-3$ & $630 \pm 10 \mathrm{pCi} / \mathrm{mL}$ \\
\hline & Cs-137 & $1.4 \pm 0.5 \mathrm{pCi} / \mathrm{gm}$ \\
\hline \multirow[t]{2}{*}{$400 \mathrm{ft}$ southeast of south fence in dry wash } & $\mathrm{H}-3$ & $340 \pm 10 \mathrm{pCi} / \mathrm{mL}$ \\
\hline & Cs-137 & $0.9 \pm 0.5 \mathrm{pCi} / \mathrm{gm}$ \\
\hline \multirow[t]{2}{*}{$320 \mathrm{ft}$ south of south fence, NE } & $\mathrm{H}-3$ & $60 \mathrm{pCi} / \mathrm{mL}$ \\
\hline & Cs-137 & $0.8 \pm 0.3 \mathrm{pCi} / \mathrm{gm}$ \\
\hline \multirow[t]{2}{*}{$320 \mathrm{ft}$ south of south fence, SE } & $\mathrm{H}-3$ & $170 \pm 10 \mathrm{pCi} / \mathrm{mL}$ \\
\hline & Cs-137 & $1.5 \pm 0.4 \mathrm{pCi} / \mathrm{gm}$ \\
\hline \multirow[t]{2}{*}{$320 \mathrm{ft}$ south of south fence, SW } & $\mathrm{H}-3$ & $15 \pm 1 \mathrm{pCi} / \mathrm{mL}$ \\
\hline & $\mathrm{Cs}-137$ & $0.5 \pm 0.3 \mathrm{pCi} / \mathrm{gm}$ \\
\hline \multirow{2}{*}{$320 \mathrm{ft}$ south of south fence, NW } & $\mathrm{H}-3$ & $11 \pm 1 \mathrm{pCi} / \mathrm{mL}$ \\
\hline & Cs-137 & $1.3 \pm 0.4 \mathrm{pCi} / \mathrm{gm}$ \\
\hline
\end{tabular}

\section{SUMMARY}

The environmental monitoring program began in May 1961 at the Beatty LLW facility. On-site environmental monitoring has been conducted by the site operator (US Ecology, Inc.) to demonstrate compliance with federal, state and local regulations; to confirm adherence to environmental protection policies; and to support the environmental management decisions.

An oversight environmental radiation program at the Beatty LLW facility has been conducted by the Nevada Radiological Health Section to provide independent on-site and off-site monitoring to ensure the adequacy and accuracy of the licensee's program. The environmental data summary report includes radioanalysis of ground water, air particulate, air tritium, surface soil, vegetation, and ambient gamma measurements using thermoluminescent dosimeters (TLDs). 


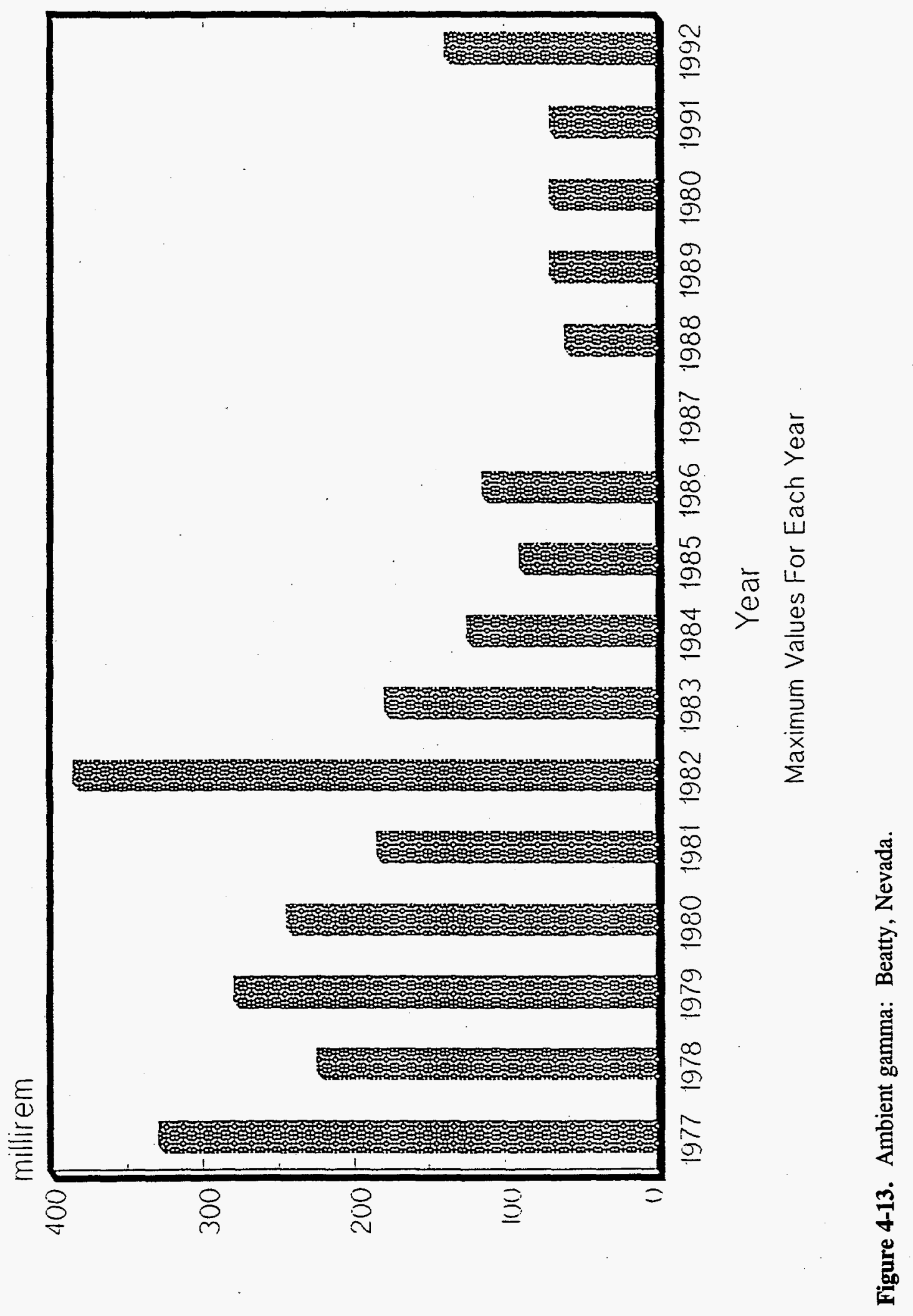


Table 4-9. Direct radiation.

\begin{tabular}{ll}
\hline Year & mrem/ $\mathrm{yr}^{\mathrm{a}}$ \\
\hline 1977 & 330 \\
1978 & 225 \\
1979 & 280 \\
1980 & 245 \\
1981 & 185 \\
1982 & 385 \\
1983 & 180 \\
1984 & 125 \\
1985 & 90 \\
1986 & 115 \\
1987 & No data \\
1988 & 60 \\
1989 & 70 \\
1990 & 70 \\
1991 & 70 \\
1992 & 140 \\
\hline Indicates the highest value for each year. & \\
\hline & \\
\hline
\end{tabular}

Results of the ground water samples (collected from site wells, the office area, and from Lathrop Wells) analyzed for gross alpha, gross beta, and tritium concentrations are presented in Table 4-3. The ground water was also analyzed for the presence of gamma-emitting radionuclides. Results of analysis from 1985 through the end of 1992 indicate a downward trend in both gross alpha and beta concentration in ground water.

Tritium activity in ground water for most years has remained below the action level of $74 \mathrm{~Bq} / \mathrm{L}$ $(2,000 \mathrm{pCi} / \mathrm{L})$ with the exception of $1979,1982,1983$, and 1984 , when a marked increase in tritium concentrations was observed from the downgradient well (\#302). These values were well below the federal regulatory limits for tritium in water for both restricted areas (0.41\% 10 CFR 20 values) and unrestricted areas (13.7\% 10 CFR 20 values). After 1984, tritium concentrations in ground water have remained below the action level. 
The gamma isotopic analysis of well water samples has indicated no detectable concentrations of manmade radionuclides in ground water..$^{4-4-7}$

Sampling for airborne tritium was performed at three monitoring stations on the site (Figure 4-3). All samples were less than the action level of $7.4 \mathrm{E}-4 \mathrm{~Bq} / \mathrm{cc}(2.0 \mathrm{E}-8 \mu \mathrm{Ci} / \mathrm{cc})$.

Air particulate sampling was performed at the same three locations as air tritium sampling. All samples analyzed for gross alpha and gross beta airborne activity concentrations were less than action levels of $18.5 \mathrm{E}-9 \mathrm{~Bq} / \mathrm{cc}(5.0 \mathrm{E}-13 \mu \mathrm{Ci} / \mathrm{cc})$ for alpha activity and $11.1 \mathrm{E}-5 \mathrm{~Bq} / \mathrm{cc}(3.0 \mathrm{E}-9 \mu \mathrm{Ci} / \mathrm{cc})$ for beta activity.-4-4-7

No trends were indicated in the gross alpha concentration data during site operations. The environmental sampling program has demonstrated that alpha-emitting radionuclides are not migrating through the soil to off-site locations.

During 1972-1976, gross beta concentration in soil samples showed an upward trend. The change in concentration is believed to be more a function of the vendor performing the analysis than any actual change in radioactivity in the soil. ${ }^{4-2}$ From 1977 to October 1985 , the gross beta concentration in soil did not vary significantly. The mean remained about $1.3 \mathrm{~Bq} / \mathrm{gm}(35 \mathrm{pCi} / \mathrm{gm})$ throughout every sampling period..$^{4-2}$ Subsequent to October 1985 , the gross beta concentration in soil has been below the action level of $3.3 \mathrm{~Bq} / \mathrm{gm}(90 \mathrm{pCi} / \mathrm{gm})$.

A review of the historical data presented in environmental reports for the Beatty site ${ }^{42-47}$ shows that the gamma spectrometry analysis of soil was performed only once during April 1982. The results of this analysis are presented in Table 4-6. ${ }^{4-2}$ Although no action levels were exceeded, Cs-137, Co-60, and $\mathrm{Mn}-54$ were detected at concentrations less than $0.03 \mathrm{~Bq} / \mathrm{gm}(0.8 \mathrm{pCi} / \mathrm{gm})$ for Cs-137, 0.003 $\mathrm{Bq} / \mathrm{gm}(0.09 \mathrm{pCi} / \mathrm{gm})$ for $\mathrm{Co}-60$, and $0.002 \mathrm{~Bq} / \mathrm{gm}(0.04 \mathrm{pCi} / \mathrm{gm})$ for $\mathrm{Mn}-54$. The State of Nevada was notified and soil and vegetation samples were split between US Ecology and the state for analysis.

Vegetation samples were collected from locations near the facility boundaries, as well as from Lathrop Wells. There was no significant difference between the different sampling points, nor any trends with respect to time at any of the sampling points. ${ }^{42-47}$

The gross beta concentration in vegetation samples varied from a low of $0.1 \mathrm{~Bq} / \mathrm{gm}(2.8 \mathrm{pCi} / \mathrm{gm})$ in 1971 to a high of $26.7 \pm 1.3 \mathrm{~Bq} / \mathrm{gm}(722 \pm 35 \mathrm{pCi} / \mathrm{gm})$ taken in 1972 . Several trends in the gross beta activity in the vegetation samples have been observed during the years 1972-1976. Subsequent to 1976 , a general downward trend was observed in the gross beta concentration, which has remained much below the action level of $7.4 \mathrm{~Bq} / \mathrm{gm}(200 \mathrm{pCi} / \mathrm{gm}) .^{42-47}$

In 1982, tritium and gamma spectral analyses of vegetation from samples outside the facility boundary were performed. The results are listed in Table 4-8. The tritium concentrations varied from $0.4 \mathrm{~Bq} / \mathrm{ml}$ to $37.0 \mathrm{~Bq} / \mathrm{ml}(11$ to $1,000 \mathrm{pCi} / \mathrm{ml})$. The State of Nevada split samples of the vegetation and the analysis varied from $2.3 \mathrm{E}-4$ to $2.4 \mathrm{E}-4 \mathrm{~Bq} / \mathrm{ml}(0.0061$ to $0.0065 \mathrm{pCi} / \mathrm{ml})$. The difference was striking and not easily explained. The most probable explanation to the differing laboratory results is chemiluminescence. ${ }^{4-2}$ Chemiluminescence can significantly interfere with liquid scintillation analysis for tritium and can be the result of the organic components in the liquid, which is derived from the 
vegetation samples. The gamma spectral analysis identified Cs- 137 with concentrations varying from 0.02 to $0.06 \mathrm{~Bq} / \mathrm{gm}(0.5$ to $1.5 \mathrm{pCi} / \mathrm{gm})$.

A review of the historical direct radiation data ${ }^{4-2}$ demonstrated that during the early years of operation, the fenceline exposures were $5.3 \mathrm{mSv}(530 \mathrm{mrem})$ for 1965 , and $12 \mathrm{mSv}$ (1200 mrem) for 1966 and decreased in later years from $3.30 \mathrm{mSv}(330 \mathrm{mrem})$ in 1977 to $0.60 \mathrm{mSv}$ (60 mrem) in 1988. 


\section{REFERENCES}

4-1. William D. Nichols "Geohydrology of the Unsaturated Zone at the Burial Site for LLW Near Beatty, Nye County, Nevada," U.S. Geological Survey, Carson City, Nevada (1986).

4-2. Beatty Site Environmental Reports - 1962-1987, US Ecology.

4-3. Beatty Site Environmental Report - 1988, US Ecology.

4-4. Beatty Site Environmental Report - 1989, US Ecology.

4-5. Beatty Site Environmental Report - 1990, US Ecology.

4-6. Beatty Site Environmental Report - 1991, US Ecology.

4-7. Beatty Site Environmental Report - 1992, US Ecology. 



\section{CHAPTER 5}

\section{Environmental Summary of the West Valley, New York \\ Low-Level Radioactive Waste Disposal Site}

\section{INTRODUCTION}

\section{Background}

The state-licensed disposal area (SDA) was constructed and operated by Nuclear Fuel Services, Inc. (NFS), during a period extending from 1963 until 1975, at which time disposal activities at the SDA were discontinued. From 1975 until March 1983, the SDA was actively maintained by the NFS. From March 1983 until present the New York State Energy Research and Development Authority (NYSERDA) has been responsible for the continued maintenance of the SDA. The SDA is presently under active maintenance. Ultimate disposition of the SDA is still undetermined.

\section{Location}

The Western New York Nuclear Service Center (Center) is located 20 miles south of Buffalo, New York, near the town of West Valley. The 3,340 acre Center is the site of the world's first commercial nuclear fuel reprocessing plant. Facilities at the Center include the nuclear fuel reprocessing plant and its ancillary facilities consisting of a fuel receiving and storage pool, high-level liquid waste storage tanks, two radioactive waste disposal areas, and a low-level liquid waste treatment plant. One of the disposal areas is the State-Licensed Commercial Low-Level Radioactive Disposal Area (SDA). All major facilities are located on a 200 acre plot near the center of the site (Figure 5-1).

\section{Facility}

Nuclear Fuel Services Co., Inc. (NFS) operated the site from 1963 to 1982 under a lease with the State of New York. The fuel reprocessing plant has not operated since 1972, and the SDA has been shut down since 1975. In February 1982, the U.S. Department of Energy (DOE) took possession of facilities at the Center (except for the SDA) for the purpose of carrying out the West Valley Demonstration Project (WVDP). The primary purpose of the WVDP, pursuant to the West Valley Demonstration Project Act (PL 96-368), is to solidify the high-level liquid wastes stored at the Center and to decontaminate and decommission the facilities used in the project. On March 30, 1983, responsibility for the SDA was officially transferred to NYSERDA.

The radioactive waste burial activities at West Valley, New York, consisted of two distinct activities: (1) commercial low-level radioactive waste burial under a New York Agreement State license from 1963 to 1975 , when NFS voluntarily stopped accepting LLW, and (2) NRC-licensed 
burial of the higher activity reprocessing plant waste from 1966 to 1986 at the NRC-licensed Disposal Area (NDA), sometimes also referred to as the "hulls burial area." These licenses were issued to co-licensees NFS and the former New York State Atomic and Space Development Authority (ASDA). The two activities and the operation of the reprocessing plant were carried out in close physical proximity. Both activities were initially carried out by the site operator and co-licensee, NFS.

This chapter will address primarily the SDA. The SDA was licensed to handle three types of radioactive wastes: (1) by-product materials including tritium, carbon-14, cobalt-60, iodine-125, iodine-131, cesium-137, and americium-241; (2) source materials including thorium-232, uranium-238, and natural uranium; and (3) special nuclear materials including uranium-235, plutonium-238, and plutonium-239. From 1963 to 1975 , about 2.35 million cubic feet of wastes (equivalent to 319,600 55-gallon drums) containing approximately 740,000 curies were disposed of in the SDA. The waste was received from a variety of sources including medical and academic institutions, industries, government facilities, nuclear power plants, waste brokers, decontamination companies, and the NFS operations at the site.

The SDA occupies approximately 6 hectares (15 acres), located about $300 \mathrm{~m}(1,000 \mathrm{ft})$ southeast of the reprocessing plant and is adjacent to the NRC-licensed disposal area (NDA). The SDA consists of two distinct sets of parallel trenches, identified as north and south disposal areas as shown in Figure 5-2. The northern area consists of five trenches $(1,2,3,4,5)$, and two "special" trenches (6 and 7). Trench 7 is a narrow, shallow concrete vault in which wastes were disposed of and Trench 6 is actually a series of holes for the disposal of high-activity wastes requiring immediate shielding. Disposal operations were conducted in this area from 1963 to 1969, except for Trench 6 which was used until 1973. The southern disposal area consists of seven trenches (8-14). This area was developed from 1969 to 1975 and incorporated a number of changes in construction practices based upon the experience gained from the northern area of the SDA: (1) topsoil and coarse surface materials were

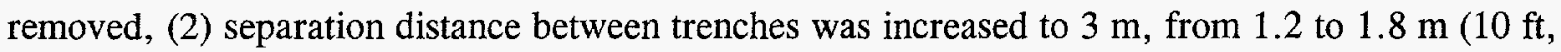
from 4 to $6 \mathrm{ft}$ ), (3) trench floors were sloped southward from wastes previously disposed of, and (4) the trenches were covered with individual caps. The trenches had nominal dimensions of approximately $180 \mathrm{~m}$ long $\times 8.25 \mathrm{~m}$ wide $\times 6 \mathrm{~m}$ deep ( $600 \mathrm{ft}$ long, $27.5 \mathrm{ft}$ wide and $20 \mathrm{ft} \mathrm{deep}$ ). Construction and operational practices by NFS at the SDA have resulted in surface contamination of soils in and near the SDA. This contamination has the potential to complete the interpretation of data from the ongoing environmental monitoring program.

The commercial low specific activity (LSA) waste, having radiation levels of less than $200 \mathrm{mRem} / \mathrm{hr}$ at the surface, was buried in the trenches. According to NFS estimates, approximately $55 \%$ of the available volume in the disposal trenches was utilized resulting in an overall activity level of less than 0.1 curie per cubic foot of trench space. The volume per trench actually used varies from $23 \%$ to $82 \%$ of that excavated. The difference reflects the use of soil for shielding and backfilling and the existence of air spaces between the containers. Because of the presence of non-compacted waste forms, the buried material is undergoing a gradual volume reduction through biodegradation and compaction, causing voids and some difficulties in maintaining the integrity of the caps on the trenches. 


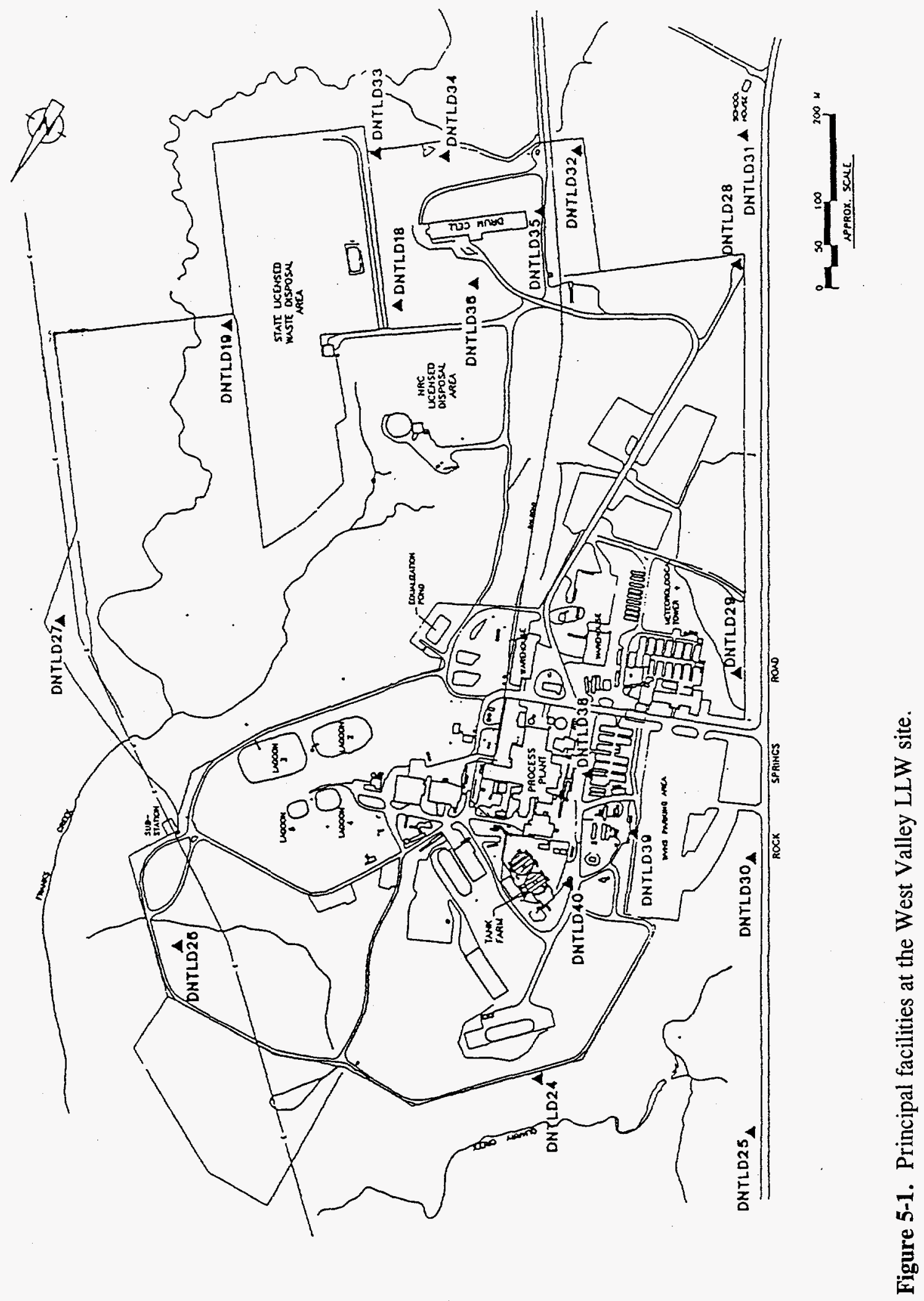


Table 5-1 summarizes the sources of the material buried through 1972. Most of the material was buried in the original shipping containers: steel drums, wooden crates, and cardboard boxes. The waste that originated at nuclear power plants consists primarily of evaporator bottoms, filter sludges, and filters, all in 55-gallon drums or in disposal liners.

A detailed summary of the wastes disposed of in the SDA through 1972 is contained in a New York State Department of Environmental Conservation (DEC) report. ${ }^{5-1}$

Table 5-1. Sources of waste in the state-licensed disposal area through $1972 .^{5-2}$

\begin{tabular}{lccc}
\hline \multicolumn{1}{c}{ Type of facility } & $\begin{array}{c}\text { Number of } \\
\text { facilities }\end{array}$ & $\begin{array}{c}\text { New York } \\
\text { based facilities }\end{array}$ & $\begin{array}{c}\text { Waste volume } \\
(\%)\end{array}$ \\
\hline $\begin{array}{l}\text { Medical and educational } \\
\text { institutions }\end{array}$ & 30 & 21 & 1.8 \\
$\begin{array}{l}\text { Industrial, pharmaceutical, } \\
\text { research and development } \\
\text { institutions }\end{array}$ & 70 & 38 & 21.5 \\
$\begin{array}{l}\text { Federal government } \\
\text { Waste disposal and }\end{array}$ & 7 & & \\
decontamination companies & 9 & 4 & 12.0 \\
Nuclear fuel services & 1 & 5 & 19.2 \\
Nuclear power plants & 8 & 1 & 23.0 \\
& 125 & 3 & 22.5 \\
\hline
\end{tabular}

Recently, as part of the environmental impact statement (EIS) for site closure, work has been done to estimate the radionuclide source term for waste management areas at the Center including the SDA. NFS estimates of the radioactivity of wastes disposed of at the SDA are shown in Table 5-2.

Since the SDA accepted waste for disposal prior to the U.S. Environmental Protection Agency (EPA) hazardous waste regulations, little indication of chemical constituents exists in the disposal records. Disposal records maintained by NYSERDA do not contain sufficient information to determine whether hazardous wastes were disposed of at the SDA. However, NYSERDA, has made an effort to chemically characterize the leachate contained in the SDA. The data provide an indirect indication of chemical constituents in each of the trenches from which samples were taken and analyzed. The results of these analyses show that in the SDA the water collecting in the trenches may come into contact with buried waste and become contaminated with chemical and radiological constituents. Due to the presence of radionuclides, these materials would be mixed wastes.

The SDA lagoon was located approximately $15 \mathrm{~m}(50 \mathrm{ft})$ west of Trench 14 in the southern part of the SDA. From 1975 to 1981, the lagoon was used to store and pre-treat leachate pumped from the SDA burial trenches. The lagoon was approximately $27 \mathrm{~m}(90 \mathrm{ft})$ long, $12 \mathrm{~m}$ (40 ft) wide and originally could accumulate liquid to a maximum depth of $2.1 \mathrm{~m}(7 \mathrm{ft})$. Maximum capacity was about 100,000 gallons. The lagoon was unlined, and was filled in 1991 with soil over a liner. Figure 5-2 shows the location of the lagoon. 


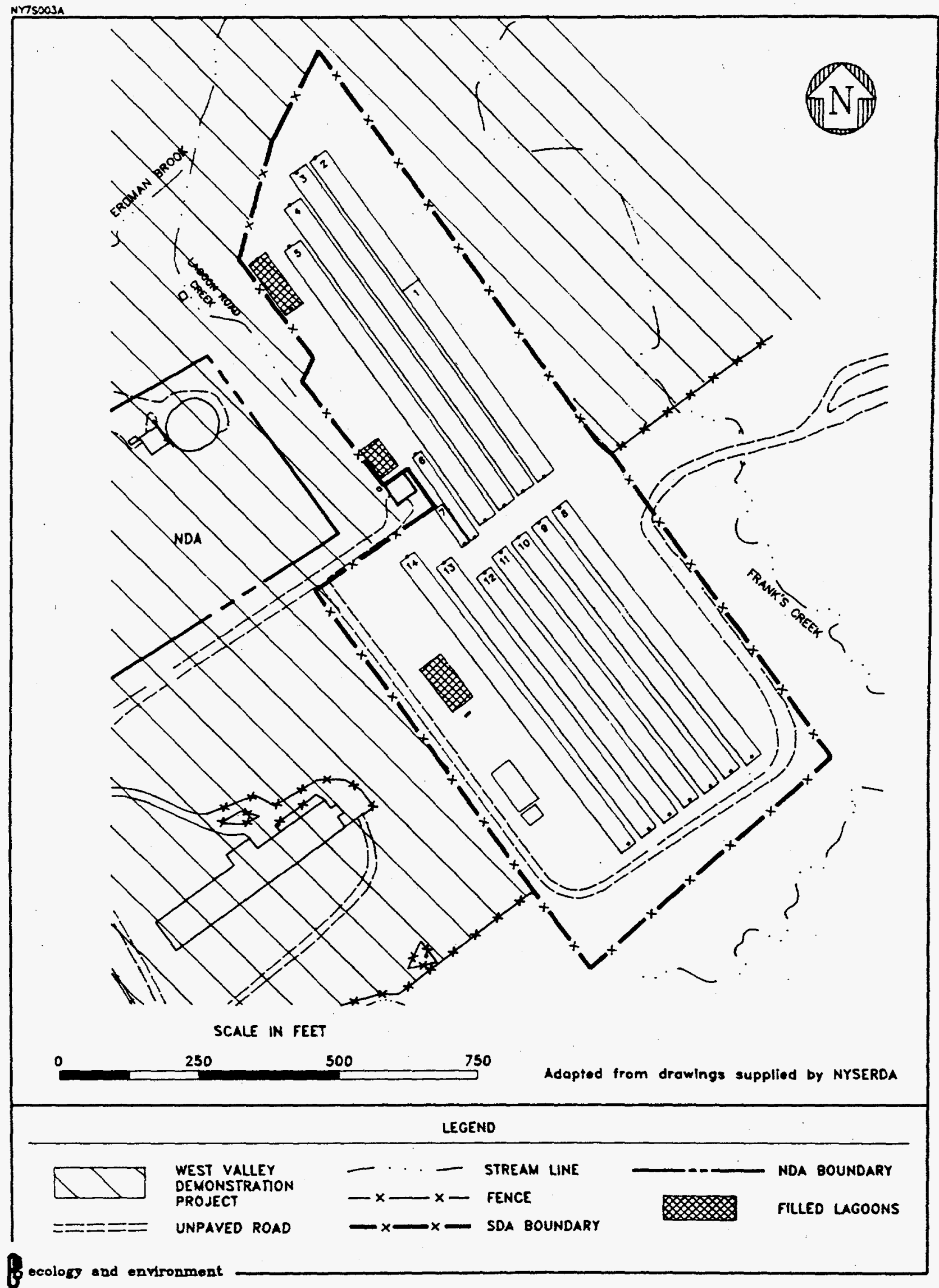

Figure 5-2. State-licensed trenches at the West Valley LLW site. 
Two other lagoons were excavated adjacent to the north trenches. The lagoons held rainwater that was pumped out of the open trenches during disposal operations to provide reasonably dry working conditions. These two lagoons were closed by filling them with soil in 1975 and 1977 . In 1975, a third lagoon was constructed adjacent to the south trenches to hold water pumped from the completed trenches that were accumulating water. This lagoon was closed in 1991 by installing a barrier membrane over the sediments, then filling it with native soil and adding a clay cap.

During the fall of 1990 , and the spring, summer, and fall of 1991 , new equipment was installed at the SDA, including an enclosed storage tank to hold contaminated water from Trench 14 and several FRAC tanks intended to provide emergency storage for trench water should levels rise unexpectedly. In the summer of 1992, a slurry wall was constructed on the west side of Trench 14 in order to minimize water infiltration into the southern SDA trenches. Trenches 14, 13, and half of trench 12 were recapped using membrane liners. These developments will be reviewed in subsequent sections of this report. Subsequently, a new geomembrane cover was placed over all trenches other than Trench 9 which had a bioengineered cover added to it.

\section{SITE}

\section{Climate}

Prior to the opening of the site, extensive climatological studies were undertaken by the U.S. Department of Commerce Weather Bureau. The average temperature was found to be $9{ }^{\circ} \mathrm{C}\left(48^{\circ} \mathrm{F}\right)$, and rain and snowfall averaged 1 and $2.25 \mathrm{~m}$ (40 and 90 in.), respectively, over a 10 - to 15 -year period..$^{5.4}$

\section{Land Use}

The area surrounding the site is rural/residential. Significant crops include trees and shrubs (for transplant) and a variety of grains and vegetables. Beef and dairy products are also produced. Population density for Cattaraugus County is less than 100 persons per square mile.

\section{Topography and Surface Water}

The West Valley site occupies a plateau which is cut by the Buttermilk Creek and its tributaries. Buttermilk Creek empties into Cattaraugus Creek which in turn flows into Lake Erie, approximately 40 miles to the northwest. The site includes most of the Buttermilk Creek Valley. At this time, and during the operating history of the site, none of the villages or cities located downstream from the site to Lake Erie uses surface water from the Buttermilk or Cattaraugus Creeks for domestic purposes. However, people do fish in the Buttermilk and Cattaraugus Creeks. The burial site is bounded by Erdmann Brook and by a small seasonal tributary of this creek (Frank's Creek). Erdmann Brook flows into the Buttermilk Creek.

The burial sites are located in the central area of the reservation, about $414 \mathrm{~m}(1,380 \mathrm{ft})$ above sea level. Buttermilk Creek and its tributaries cut through the area at an elevation of approximately $400 \mathrm{~m}(1,300 \mathrm{ft})$. The valley walls of Buttermilk Creek and its tributaries are steep, and badly slumped 
in places. The site is generally well drained with the exception of a marshy area to the south of the burial area.

\section{Geology and Ground Water}

Extensive geologic and hydrologic studies were undertaken by the New York State Geological Survey (NYSGS) and the United States Geological Survey (USGS) before and during 1963. These studies included a boring program of 108 augured holes and 14 deep wells. ${ }^{5-5}$ These wells and borings indicated deep, low-permeability clays, which were thought at the time to make the site promising for a disposal area. Figure 5-3 shows a geological cross section of the West Valley site. Subsequent experience with the site has shown that burial trenches have a tendency to fill with water and that the potential for horizontal leachate migration is not as minimal as originally thought due to the presence of sand lenses and other permeable structures within the weathered till and upper layers of unweathered till. The primary direction of ground water flow at the SDA is downward. The disposal trenches were excavated into the native Lovery till, which because of its high clay content and high degree of overconsolidation, is highly impermeable at depth. Samples taken from boreholes have indicated, however, that the upper three meters of the till are weathered as a result of desiccation. The weathered till is highly fractured and is generally more permeable than the unweathered till.

\section{ENVIRONMENTAL MONITORING}

\section{Overview}

The SDA began operations in 1963, three years prior to the beginning of operations at the NFS reprocessing plant. During this three year period, environmental monitoring at West Valley was carried out by the New York State Department of Health to establish background levels for the subsequent monitoring of the reprocessing plant. Also, during this period, the off-site monitoring program consisted of the following: (1) monthly surface water sampling for gross beta and selected radionuclides including iodine-131, cesium-137, barium-140, strontium-89, and strontium-90 carried out in the Cattaraugus Creek watershed at the Springville Dam and upstream of the NFS plant; (2) air monitoring for gross beta at several locations in the immediate vicinity of the NFS plant; and (3) monthly analysis of milk from 16 local dairy herds for iodine-131, cesium-137, barium-140, strontium-90, and strontium-89. All data prior to April 1966 were regarded by Nuclear Fuels Services and the State Health Department as background data. Gross beta levels in water were 1-3 pCi/L, air gross beta was generally less than $1 \mathrm{pCi} / \mathrm{L}$, and no significant concentration of radionuclides was observed in milk.

In November 1966, gross beta concentrations increased from about an average of $3 \mathrm{pCi} / \mathrm{L}$ to an average of $252 \mathrm{pCi} / \mathrm{L}$ in the Cattaraugus Creek at the Springville Dam. During this same period, other sampling sites upstream of the plant showed levels between 1 and $3 \mathrm{pCi} / \mathrm{L}$. Levels in air and dairy herd levels showed no significant change. By the end of 1966, the downstream creek environment had concentrations of various nuclides significantly higher than before plant operation. No off-site samples, however, showed levels that exceeded the concentration limits set forth in 10 CFR 20 of the U.S. Atomic Energy Commission regulations. There was no detectable rise in radioactivity due to stack discharges in the area surrounding the plant up to the end of 1966. 
Table 5-2. West Valley trench inventory. ${ }^{5-3}$

\begin{tabular}{ccccc}
$\begin{array}{c}\text { Trench } \\
\text { No. }\end{array}$ & $\begin{array}{c}\text { Length } \\
\text { (feet) }\end{array}$ & $\begin{array}{r}\text { Trench volume } \\
\left(\mathrm{ft}^{3}\right)^{\mathrm{a}}\end{array}$ & $\begin{array}{c}\text { Waste } \\
\text { volume } \\
\left(\mathrm{ft}^{3}\right)\end{array}$ & $\begin{array}{r}\text { Activity } \\
\text { (curies) }\end{array}$ \\
\hline 1 & 365 & 233,000 & 55,300 & 4,100 \\
2 & 335 & 213,000 & 114,200 & 2,200 \\
3 & 695 & 443,000 & 198,000 & 17,100 \\
4 & 660 & 421,000 & 274,400 & 67,100 \\
5 & 535 & 341,000 & 278,400 & 92,800 \\
$6^{\mathrm{b}}$ & 160 & 112,300 & 500 & 339,600 \\
$7^{\mathrm{c}}$ & 73 & 11,000 & 2,500 & 1,600 \\
8 & 565 & 360,000 & 252,400 & 38,700 \\
9 & 560 & 360,000 & 175,800 & 34,200 \\
10 & 560 & 360,000 & 185,800 & 54,900 \\
11 & 560 & 360,000 & 182,800 & 53,500 \\
12 & 555 & 355,000 & 196,700 & 11,200 \\
13 & 610 & 390,000 & 207,800 & 7,400 \\
14 & 655 & 420,000 & 229,800 & 12,300 \\
Total (without 6) & & $4,297,000$ & $2,354,600$ & 397,100 \\
\hline Total (with 6) & & & $2,355,100$ & 736,700 \\
& & & &
\end{tabular}

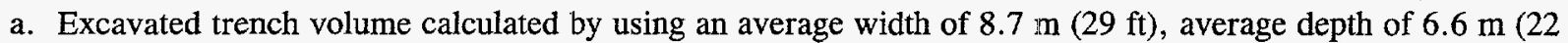
ft) times the length, except for trenches Nos. 6 and 7 .

b. Trench No. 6 consists of 19 separate holes in an area $4.5 \mathrm{~m}(15 \mathrm{ft})$ wide and $48 \mathrm{~m}$ (160 ft) long. Depth

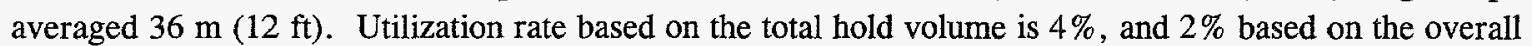
trench excavation volume.

c. Trench No. 7-special purpose concrete vault-21.9 m (73 ft) long, about $3 \mathrm{~m}(10 \mathrm{ft})$ wide, and about 4.5 $\mathrm{m}(15 \mathrm{ft})$ deep. 
During this period, the effects of the discharges from the NFS plant were evident on the Buttermilk and Cattaraugus Creeks sampling stations. The U.S. Atomic Energy Commission did not establish limits for the section of Buttermilk Creek which received the wastes because that section was within the NFS site boundary and under the control of NFS. Concentration limits were applied to Cattaraugus Creek after the confluence of Buttermilk Creek. The limits for gross beta were considered to be 300 and $600 \mathrm{pCi} / \mathrm{L}$ for the yearly and maximum values, respectively, if an isotopic analysis was not made. The allowable concentrations in $\mathrm{pCi} / \mathrm{L}$ for each specific radionuclide averaged over a year's period were as follows: strontium-90 - 300, cesium-137 - 20,000, zirconium-Nb-95 - 60,000, barium-140 - 30,000, strontium-89 - 3,000, and tritium -3 million.

Through 1968, the program and the results thereof were essentially unchanged. On a yearly basis, the average concentrations allowed by the U.S. Atomic Energy Commission in Cattaraugus Creek were not exceeded. A single sample taken from Cattaraugus Creek on September 23, 1968, at Felton Bridge showed a gross beta concentration of $721 \mathrm{pCi} / \mathrm{L}$. This sample was analyzed for specific nuclides and reported. ${ }^{5-6}$ The sample was within limits allowed by the U.S. Atomic Energy Commission.

In 1968, the New York State Department of Health published the first analysis of deer and fish from the West Valley area and the Cattaraugus Creek. The first three deer were taken from the 36 hectare (90 acre) exclusionary zone within the site for sampling in December of 1967 . The highest concentration of cesium- 137 was found to be approximately $67,000 \mathrm{pCi} / \mathrm{kilogram}$. It was thought that the deer ingested the radioactive material by drinking the relatively highly contaminated water in the waste lagoons or from the discharges of these lagoons. Also, cesium-134 was present, which is indicative of wastes from spent fuel. Based on these results, the New York State Department of Health instituted a regular sampling program for deer in the 1320 hectare (3,300 acre) preserve, but outside the 27 hectare ( 90 acre) exclusion area. Deer taken from outside the exclusion area were found to have much lower concentrations of radionuclides. The State Health Department subsequently required barriers at the deer access points to the high exclusion area and NFS erected them. The exclusion area, however, is not considered to be deer-proof.

In the same time period, fish samples began to be taken in the creek system above and below the NFS discharge point. In most cases, the entire fish including bone, flesh, intestines, and scales was analyzed. The results indicated that fish, mostly suckers, tend to reconcentrate strontium 90. Suckers are taken from Cattaraugus Creek for food especially in the springtime. The State Health Department collected samples and determined that some of the highest values for strontium-90 found in the fish and determined that the Radiation Protection Guide for an individual might be exceeded if that person were to eat $78 \mathrm{lbs}$. of fish per year. It is considered unlikely that one individual would be able to take this amount of fish from Cattaraugus Creek in the vicinity of Buttermilk Creek. However, because of the possibility that in the future the concentrations might go higher, the matter was brought to the attention of the U.S. Atomic Energy Commission with an expression of concern on the part of the New York State Department of Health. The AEC at this point (1968) requested that NFS reduce the level of radioactivity in the discharges.

During March, June, and September of 1968, three separate releases of airborne contaminants occurred due to filter failures at the main plant. The New York State Department of Health investigation concluded that contamination from the incidents was contained within the parking lot 


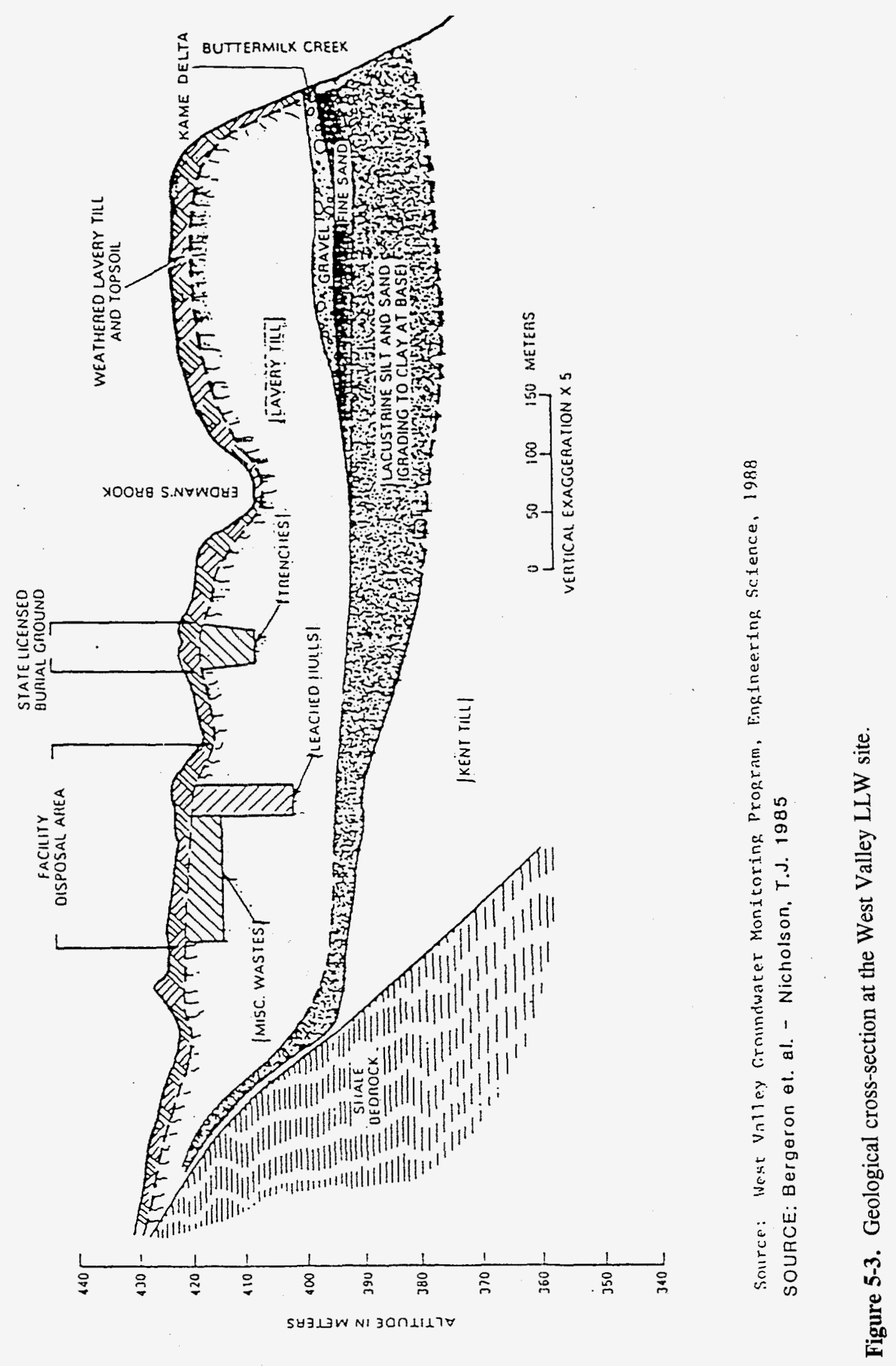


adjacent to the plant and did not migrate off-site. Several Aerial Radiological Measuring Surveys (ARMS) were conducted by EG\&G in 1968, 1969, and 1970 using NaI detector arrays. These surveys did not show significant contamination from the filter failures. Subsequent ARMS carried out in 1979 and 1984 with more sensitive instrumentation indicated a cesium prong extending NW of the site. Offsite sampling carried out in 1982 showed elevated levels in soil samples taken from the prong area. Between 1993 and 1995, NYSERDA characterized this area.

In 1970, extensive studies of ingestion dose pathways for radionuclides from the NFS plant were begun by the EPA [3]. Three major pathways were examined: (1) dose from ingestion of fish from the Cattaraugus Creek, (2) dose from consumption of venison taken near the West Valley site, and (3) dose from radionuclide concentrations in diets of populations living in the vicinity of the NFS plant. The last study used a 'market basket' approach sampling selected dietary items purchased in Riceville and West Valley which could have originated locally and homegrown garden vegetables and fruits from seven homeowners near the plant perimeter. The vegetables and fruit were consumed by the families and not sold commercially. Vegetables and fruits from produce farms in Chafee, New York and Winchester, Massachusetts served as controls. These samples were analyzed for gamma-emitters, strontium-90, and tritium. The results of these studies were published in $1974 .^{5-7}$ From the results of these studies, the following estimates were made by the Health Department concerning the dose commitments to the population fishing and hunting in the vicinity of NFS resulting from waste discharges from the plant:

1. Whole body doses to population fishing the Cattaraugus Creek during 1971:

Integrated population dose -0.06 person-rem (0.04 person-rem external, 0.02 person-rem from ingestion)

Maximum individual dose-1.4 mrem (1 mrem external, 0.4 mrem from ingestion)

2. Dose to bone from ingestion of strontium-90 for population fishing Cattaraugus Creek during 1971:

Integrated population dose- 0.3 person-rem

Maximum individual dose $-0.7 \mathrm{mrem}$

3. Whole-body doses to population from ingestion of venison from deer kill in 1970:

Integrated population dose- 0.1 person-rem

Maximum individual dose-1.4 mrem

4. Dose to bone from ingestion of strontium-90 in venison resulting from the NFS discharges could not be determined from the available data.

The sampling of fish, venison, and farm produce has continued to date as part of the regular West Valley monitoring program.

Levels of strontium-90 in Cattaraugus Creek continued to rise through 1970 despite NFS efforts to reduce concentrations. Figures 5-4 and 5-5 show strontium-90 and tritium concentrations in the 


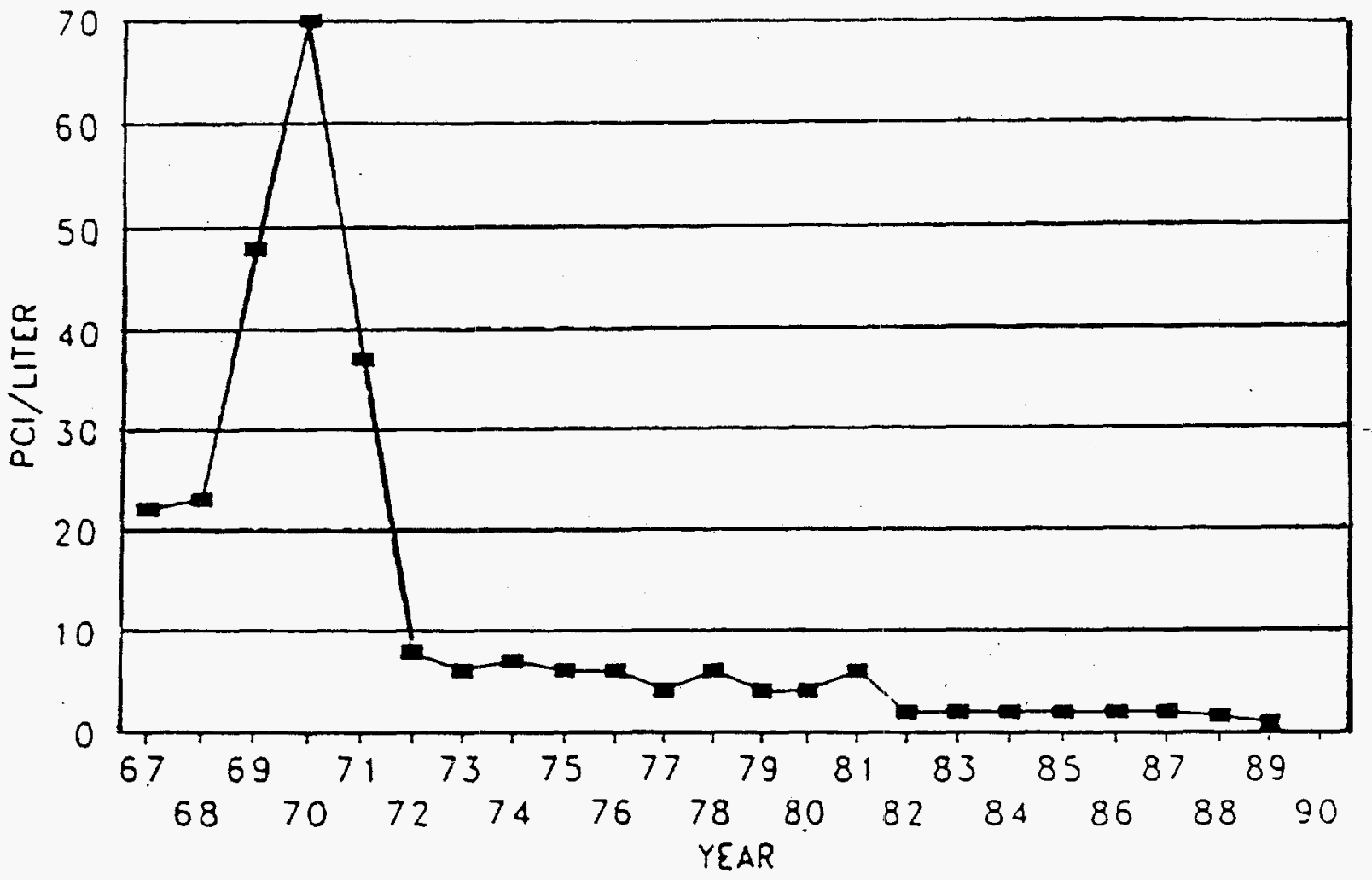

Figure 5-4. Strontium-90 in Cattaraugus Creek at Springville Dam.

Cattaraugus Creek from 1967 to 1989 . In November of 1971, NFS suspended fuel reprocessing operations.

All of the monitoring procedures discussed above were intended to monitor releases from the NSF plant. Monitoring of the low-level radioactive waste disposal site was only incidental. In the early 1970 's, however, the newly created DEC assumed responsibility for the monitoring of environmental radiation levels in New York State. Awareness of the need to monitor the SDA burial trenches for possible release of radionuclides into ground or surface waters increased. Therefore, beginning in 1972, additional surface locations near the trenches were sampled for radionuclides, and a sampling program for wells, springs, and public water supplies in the area surrounding the NFS plant was begun. Iodine-129 and -125 were given specific attention in these new sampling programs using a liquid scintillation technique. Additionally, various fauna including rabbits and woodchucks were taken and analyzed for radionuclide content, particularly I-129 contained in the thyroid. Also during 1972, a regular program of sampling radionuclide concentrations in the lagoons was initiated, as was sediment sampling at water sampling locations downstream of the NFS facility.

Prior to 1972 , precipitation entering an open trench, which came in contact with waste packages before covering, was pumped to the surface or to holding lagoons in order to provide dry working conditions for workers in the trench. The waters in the lagoons were analyzed and discharged at a controlled rate into Erdmann Brook. This direct discharge was eliminated during November 1972 and water from the burial site holding lagoons was thereafter pumped to the main NFS plant for treatment 
in the low-level radioactive waste treatment plant. This change in procedure contributed to the lower radionuclide levels observed in the Cattaraugus Creek in the early 1970's.

In 1975 , radioactivity levels in watercourses below the NFS main plant and below the low-level radioactive waste disposal site increased because of the trench water seepage out of the cover and the subsequent pump out of the trenches at the low-level burial site. The water levels in Trenches 4 and 5 at the north end of the burial site reached elevations such that a physical breakthrough of the trench water through the soil cover was observed in the north end of Trench 4 and along the west side of Trench 5 in early March. The breakthrough caused increased activity in streams below the burial site and main plant. It was necessary to pump 270,000 gallons of water from Trenches 3, 4, and 5 to lower the water level in the trenches and prevent further breakthrough. The water was pumped out of the trenches to the burial site holding lagoons and eventually transferred to the main plant for treatment and discharge. An increase in activity, primarily tritium, in streams below the NFS main plant discharge occurred from June 14 to July 1,1975 , due to the controlled release of the treated trench water.

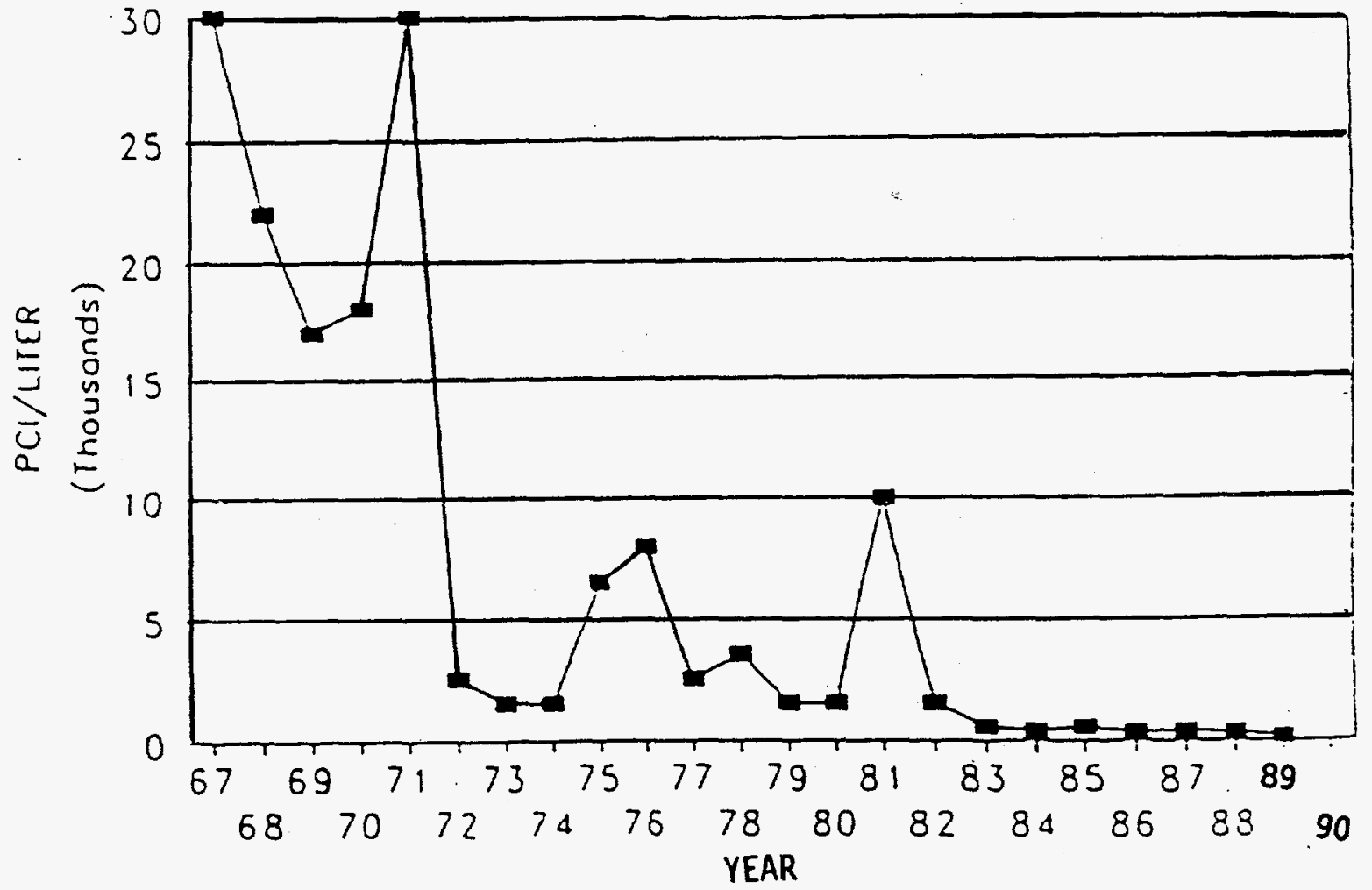

Figure 5-5. Tritium on Cattaraugus Creek at Springville Dam.

A second pump-down, designed to prevent further trench water breakthrough, was initiated on September 29,1975 . On October 6,1975 , during a routine monitoring visit to the burial site, a DEC representative discovered there had been leakage from the north burial site holding lagoon. Upon notifying NFS officials, it was learned that the seepage through the wall of the lagoon had been observed on October 5, 1975. The level in the lagoon had been lowered on October 5 by pumping the waste to the south lagoon until the seepage had ceased. DEC estimated that approximately 7,000 gallons of untreated trench water had been released to the environment. 
Figure 5-6 shows the NFS plant area and the LLW burial area and on-site surface water sampling locations. The highest gross beta, tritium, and strontium-90 concentrations for 1975 were found at sites 53 (Erdmann Brook), 35 (Buttermilk Creek), and 42 (Cattaraugus Creek). They were obtained from samples collected on October 6,1975, and were a direct result of the burial site lagoon seepage. The maximum concentration of tritium in the weekly composite samples at Springville Dam following the lagoon seepage was $10.7 \%$ of the NFS's maximum allowed levels for Cattaraugus Creek. Strontium-90 maximum level reached $15 \%$ of the technical specifications for Cattaraugus Creek. [The NFS technical specifications in 1975 stated that the concentration of radioactivity in the Cattaraugus Creek would not exceed either: (1) $10 \%$ of the prorated concentration listed in Appendix B, Table II, 10 CFR Part 20 averaged over any quarterly period; or (2) $20 \%$ of the prorated concentration listed in Appendix B, Table II, 10 CFR Part 20 for any weekly composite sample taken in accordance with Technical Specification 5.1.1.].

During 1975, the other routine monitoring programs at West Valley (air, venison, fish, farm produce, water supplies, milk, fauna, etc.) showed generally decreasing levels of radioactivity.

From 1976 to 1981 , the overall monitoring program remained essentially unchanged. There were no significant incidents involving release of radionuclides to the environment. Water levels in some trenches, however, showed a consistent tendency to rise. Water was pumped from several trenches during this period. This water was pumped out of the trenches to the burial site holding lagoons and eventually transferred to the main plant for treatment and discharge. An increase in tritium in streams below the NFS main plant discharge point occurred due to the controlled release of the treated trench water. At no time during this period did the radionuclide concentrations at Springville Dam or Cattaraugus Creek approach the technical specifications for the site.

In October 1982, the New York State Department of Health reassumed responsibility for the monitoring of environmental radiation levels in the state, a task previously performed by the Department of Environmental Conservation. This did not have a major impact on the format of the monitoring program. Some of the biological sampling programs, specifically the sampling of thyroids from rabbits and woodchucks, were curtailed about 1982 .

From 1982 to 1986, the monitoring program continued unchanged and with uneventful results. In 1987, a remedial action program was instituted for Trench 14 including removal of a sand lens to prevent potential ground water migration of radionuclides from the trench. This program was completed late in the summer of 1987. The effectiveness of the sand lens removal in slowing the rate of rise in water levels in Trench 14 initially appeared to be good. Recent developments, discussed in later sections of this report, have further reduced the rate of water infiltration into Trench 14 .

Figure 5-7 shows the location of the SDA and the nearby currently used air, milk, and water sampling locations and Figure 5-8 shows the locations of all on-site sampling. Table 5-3 shows the 1989 locations and sampling frequencies of TLD sites used to monitor radiation levels.

\section{Ground Water Monitoring}

Prior to 1990 , ground water has been monitored less for the SDA than would be required by current standards for new LLW facilities. From 1975 to 1983, the USGS conducted ground water 
monitoring and sampling at a limited number of wells on or near the SDA. Data gathered in this study was used to develop a model of ground water flow characteristics for West Valley including, but not restricted to, the SDA. A variety of ground water studies addressing ground water flow characteristics were carried out between 1975 and the present, none of which provided sufficient information on ground water quality at the SDA to provide a thorough understanding for characterization.

In 1987, NYSERDA began to prepare a more comprehensive ground water monitoring program for the SDA, which was integrated with the DOE ground water monitoring program for the Western New York Nuclear Service Center. Unlike previous efforts, this program addresses potential horizontal migration of trench water from the SDA. The program is summarized in a report prepared for NYSERDA..$^{5-7}$ Much of the information presented below is taken from this report. The new program is designed to be compatible with the NRC performance objectives for LLW in 10 CFR Part 61.41 and 10 CFR 61.53, which require maintenance of a monitoring system capable of providing early warning of releases of radionuclides before they leave the site boundary. The NRC identifies ground water as the most probable path of migration for release of radionuclides from a low-level radioactive waste disposal site. ${ }^{5-9}$ Because the trenches contain hazardous constituents as well as radioactive materials, the new monitoring plan was designed to take into account the requirements of the Resource Conservation and Recovery Act (RCRA).

In order to determine whether and at what rate water contained in SDA trenches is migrating through the ground water regime, it is useful to categorize that water for purposes of identification. Accordingly, analysis of trench water was performed by NYSERDA. Tritium, strontium-90, and carbon-14 are the chief radioactive components of the trench water. ${ }^{5-10}$ Dissolved metals present included sodium, potassium, and iron, while the highest observed levels of dissolved non-metals were for chloride and organic carbon. ${ }^{5-11}$ Finally, NYSERDA conducted an analysis of water taken from all trenches which identified the most abundant organic compounds as being toluene, benzine, phenols, chloroform, 1,1-dichloroethane, 1,2-dichloroethane, methylene chloride, naphthalene, and ethylbenzene..$^{5-12}$ In preparing the SDA ground water monitoring program, NYSERDA's consultants included these organic compounds as indicator analytical parameters due to their abundance and toxicity. ${ }^{5-13}$

The ground water monitoring program (Figure 5-9) includes ground water elevations to be measured in 11 of the existing USGS wells. Other extant wells will not be utilized due to inappropriate construction or other defects. None of the older wells will be sampled for leachate indicator and ground water quality parameters. Twenty-one new wells have been installed are sampled for leachate indicator and water quality parameters. Since the main purpose of the new wells is to detect contaminants in the ground water that flows into and out of the SDA, it is important that the well screens intersect ground water flow paths. NYSERDA's consultants identified two main potential ground water flow paths at the SDA; (1) through the weathered till, and (2) vertically through the unweathered till to the deep lacustrine deposit. ${ }^{5-6}$ In some locations, wells were installed in triplets or pairs and screened at different depths in order to monitor the weathered till, the unweathered till, and the lacustrine unit. Wells employ stainless steel construction rather than the polyvinyl chloride (PVC) used for past wells.

Sampling of the wells during the first three years of operation was carried out in order to facilitate the identification of seasonal variations. Sampling is currently semi-annual. Parameter concentrations 


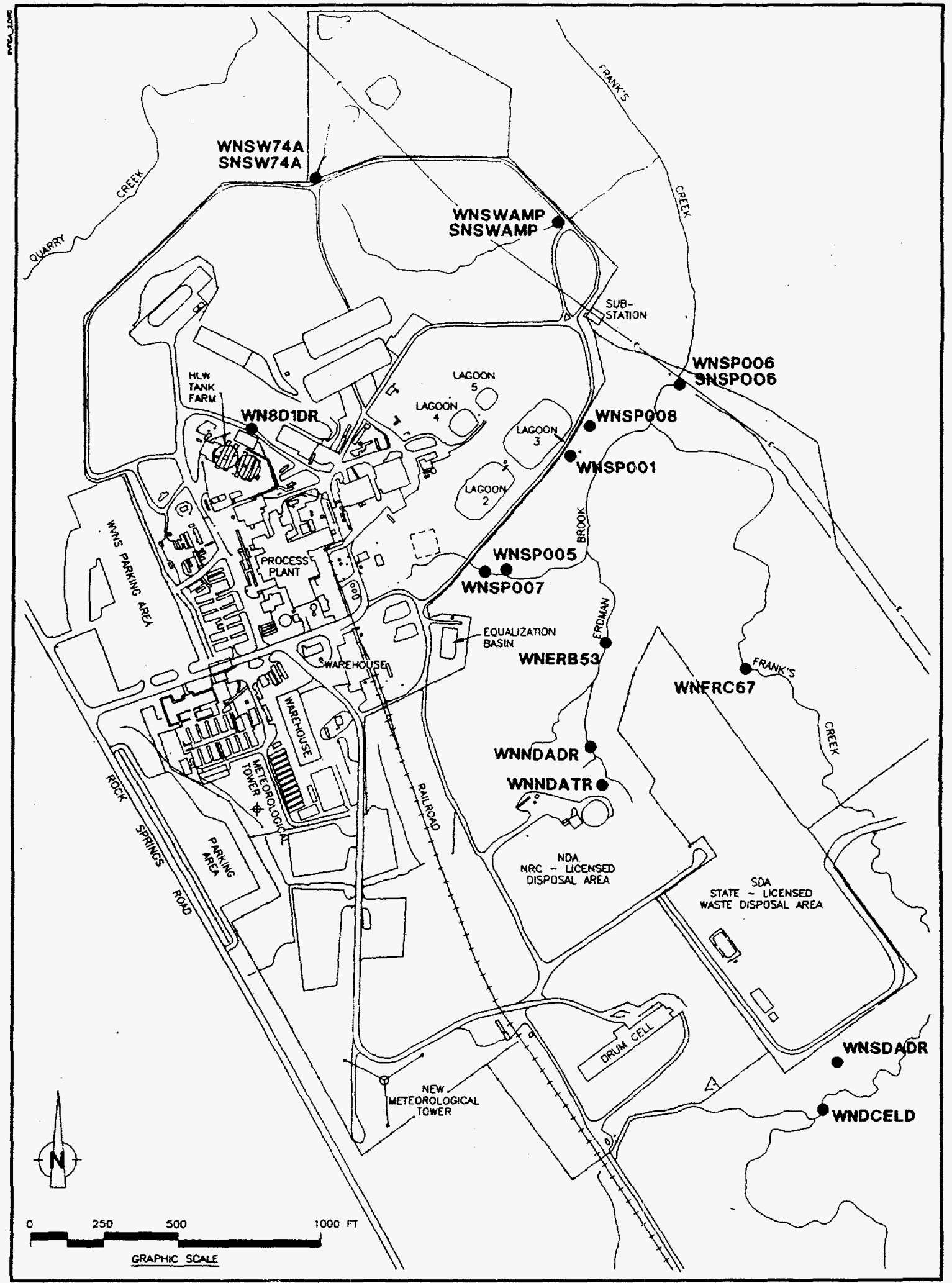

Figure 5-6. On-site surface water sampling locations at the West Valley LLW site. 


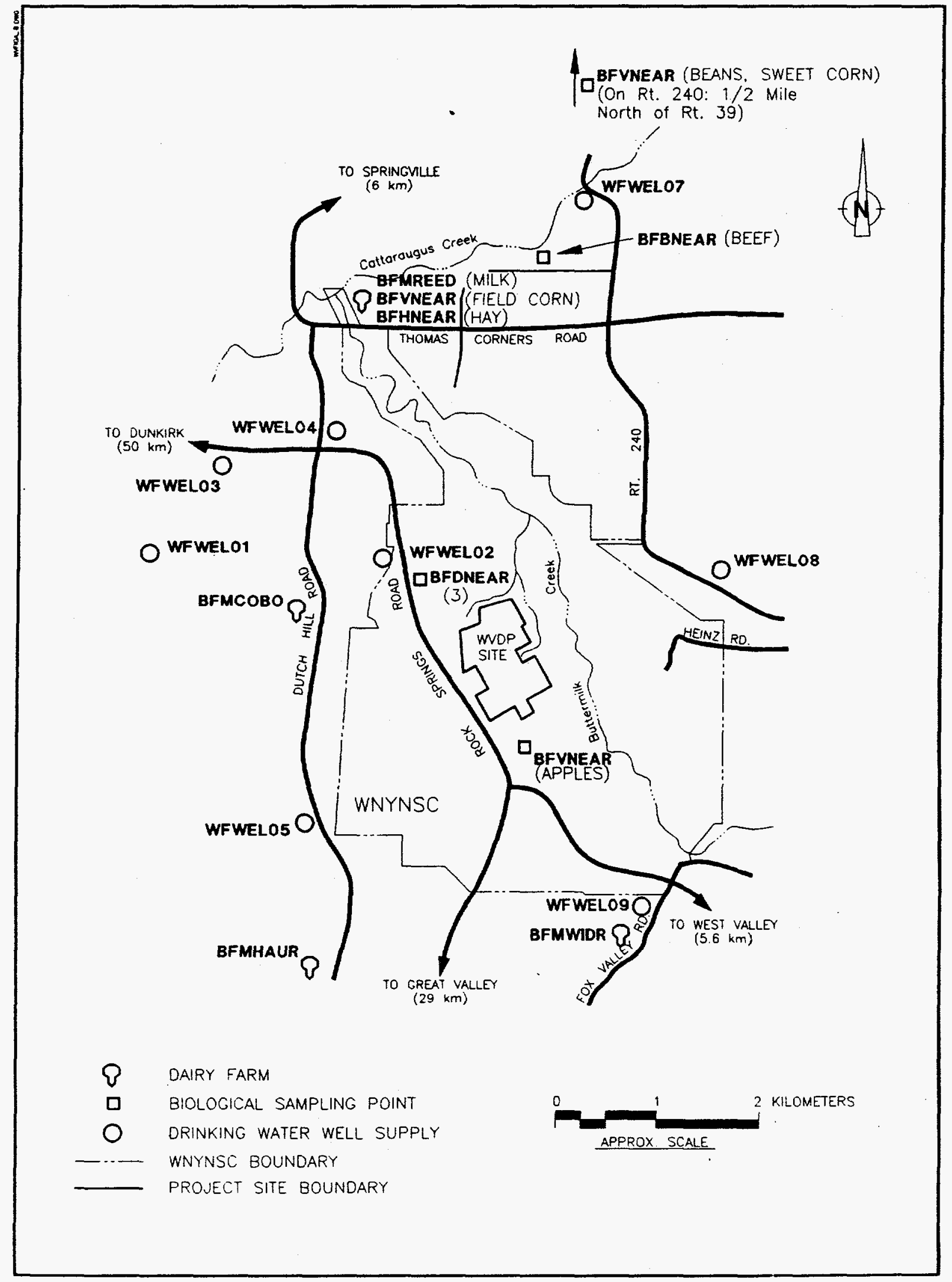

Figure 5-7. West Valley demonstration project sampling site. 
in down-gradient wells exceeding three times the background level will trigger resampling and possible sampling for additional parameters with the additional parameters selected from the same group of compounds, elements, or radionuclides.

Results for several rounds of sampling for radionuclides are now available. Tritium levels in well 1107A near Trench 5 have leveled out at $20,000 \mathrm{pCi} / \mathrm{L}$.

During the winters of 1990-1991 and 1991-1992, water levels in several trenches at the SDA, particularly Trenches 13 and 14, rose substantially. Trench water level data from these two trenches seemed to imply a hydraulic connection between them just below the boundary between the weathered and unweathered till. In an attempt to arrive at a better understanding of the source of the intrusive water and in order to develop corrective measures to prevent further influx, NYSERDA and its consultants, in conjunction with DEC technical staff, installed a network of 20 new piezometers at and around the SDA concentrated in the Trench 14 area. In order to minimize further rises in trench water levels, a slurry wall approximately thirty feet deep was installed on the west site of Trench 14 during the summer of 1992. In conjunction with this, all trenches (except Trench 9) have been recapped using a geo-membrane liner. Nine slit wells have been installed around the southwest SDA perimeter to monitor the effects of slurry wall installation and recapping.

Until the winter of 1990-1991, NYSERDA monitored water levels in all trenches on a monthly basis. Rising water levels in several trenches, particularly Trenches 13 and 14 have prompted bi-weekly monitoring of trench water levels in 1991 and 1992. Also, during the summer of 1991 , preliminary closure of the SDA lagoon was undertaken. Monitoring of radionuclide levels in lagoon water has been replaced by additional ground water monitoring efforts in the lagoon area.

An issue with geology and groundwater is the fact that the trenches will slowly fill with water due to the "bathtub effect." If left uncontrolled, the contaminated water would eventually overflow laterally into the environment. Therefore, it is important to monitor water levels in the trenches to make sure that appropriate actions can be taken to ensure this does not happen.

The recent improvements in ground water monitoring at the SDA are likely to lead, within a few years time, to an enhanced understanding of the potential for contaminant migration at this facility. As data are accumulated, additions, modifications, and improvements will be made to the existing monitoring system.

\section{Surface Water}

In accordance with the NYCRR Part 380 Land Burial Permit, NYSERDA is also sampling surface water. The north and east slopes of the SDA are steep ravines leading to Frank's Creek and Erdman Brook, respectively. These slopes may intersect lateral flow in the weathered till resulting in a seep. Samples taken from seeps and other surface water may provide a useful check on possible migration of ground water from the SDA trenches. Samples taken to date, however, give no clear indication of extensive horizontal migration. There are four off-site surface water monitoring points historically used by NFS that continue to be used by WVDP: two in Buttermilk Creek, one in Cattaraugus Creek, and one at Springville Dam. Figures 5-10 and 5-11 show tritium and strontium-90 


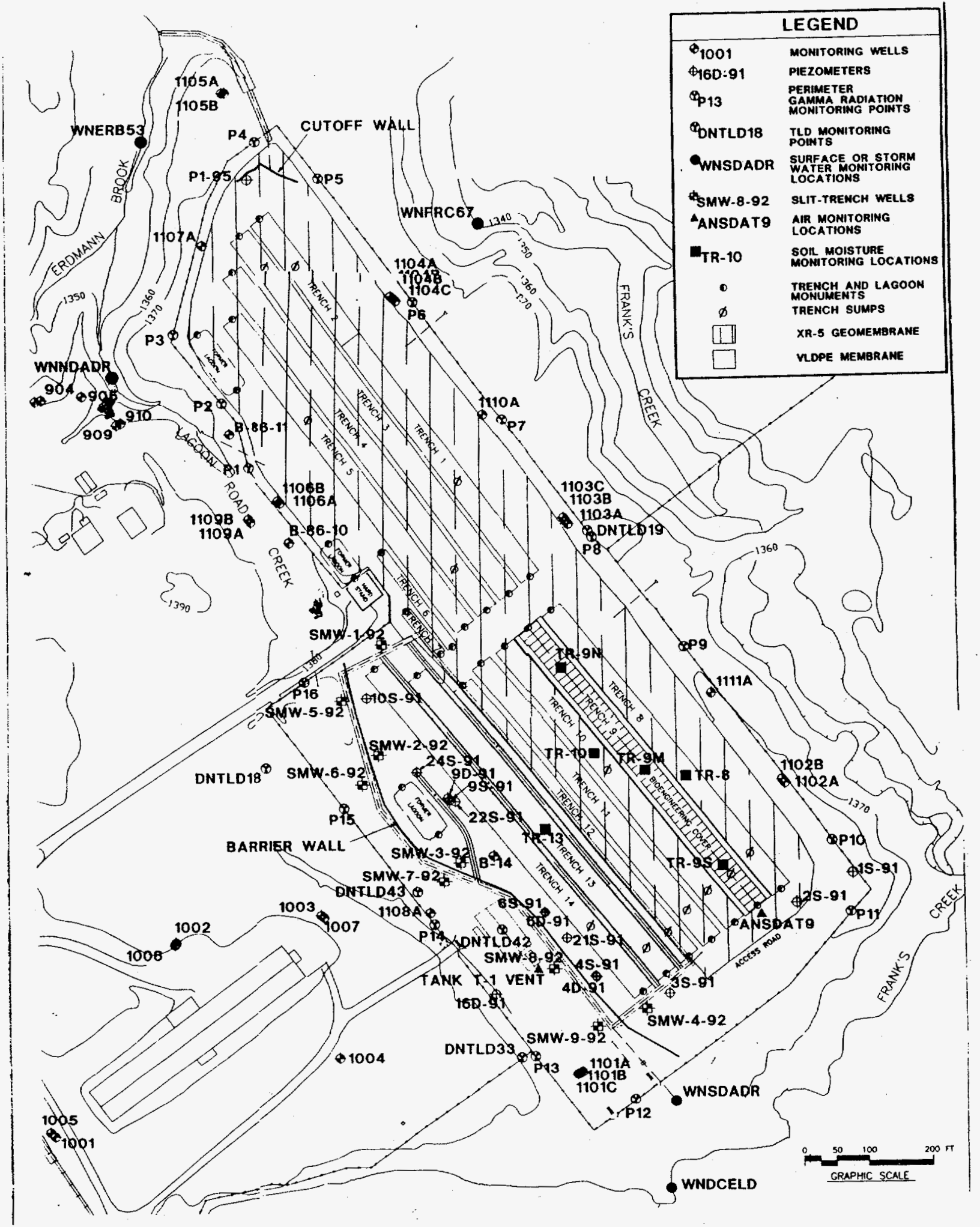

Figure 5-8. West Valley demonstration project on-site sampling. 
concentrations at the Springville Dam from 1967 to 1991 . Tritium levels in 1975, 1976, and 1981 are indicative of pumping of trenches at the SDA. Prior levels are attributed to NSF plant discharges.

\section{Air}

Currently there are nine perimeter and offsite air sampling locations associated with the Center. In addition, each individual emission point is routinely sampled. For the SDA, air is sampled from the T-1 tank stack semiannually. Ambient air is sampled and analyzed at the SDA near Trench 9 in accordance with the NYCRR Part 380 permit for the bioengineering project.

\section{Direct Radiation}

There are seven thermoluminescent dosimeter (TLD) locations which are sampled quarterly. These measure direct radiation. Additionally, area radiation monitoring system (ARMS) surveys were

Table 5-3. West Valley demonstration project sites..$^{5-8}$

\begin{tabular}{|c|c|c|c|}
\hline $\begin{array}{c}\text { Map } \\
\text { location } \\
\end{array}$ & Type & Location & Frequency \\
\hline 1 & Air & NE of site 1 mile & Weekly \\
\hline \multirow[t]{3}{*}{2} & Milk & $\mathrm{N}$ of site 1 mile & Monthly \\
\hline & Milk & WNW of site 1.9 mile & Monthly \\
\hline & Water & Swamp drainage & Monthly \\
\hline \multirow[t]{3}{*}{3} & Water & $\begin{array}{l}\text { Buttermilk Creek (at Fox Valley Rd. bridge) } \\
\text { Erdman Brook on site }\end{array}$ & Monthly \\
\hline & Water & Cattaraugus Creek (at Bigelow bridge) & Monthly \\
\hline & Water & $\begin{array}{l}\text { Buttermilk Creek (at Thomas Corners Rd.) } \\
\text { Cattaraugus Creek (at Felton bridge) }\end{array}$ & Quarterly \\
\hline 4 & Water & $\begin{array}{l}\text { Erdman Brook } \\
\text { Brook near burial site }\end{array}$ & Monthly \\
\hline 5 & Water & $\begin{array}{l}\text { Springville dam } \\
\text { Buttermilk Creek }\end{array}$ & Monthly \\
\hline 6 & Water & Springville dam & Monthly \\
\hline \multirow[t]{10}{*}{7} & Water & Near site & Monthly \\
\hline & Water & Near site & Monthly \\
\hline & Sediment & Within site boundary & Annually \\
\hline & Sediment & Farm near site & Semi-Annually \\
\hline & Vegetation & Springville dam & Annually \\
\hline & Vegetation & 7 locations & Annually \\
\hline & Deer & & Annually \\
\hline & Beef & & Annually \\
\hline & Fish & & Annually \\
\hline & TLD & & Quarterly \\
\hline
\end{tabular}






Figure 5-9. West Valley on-site ground water monitoring network. 


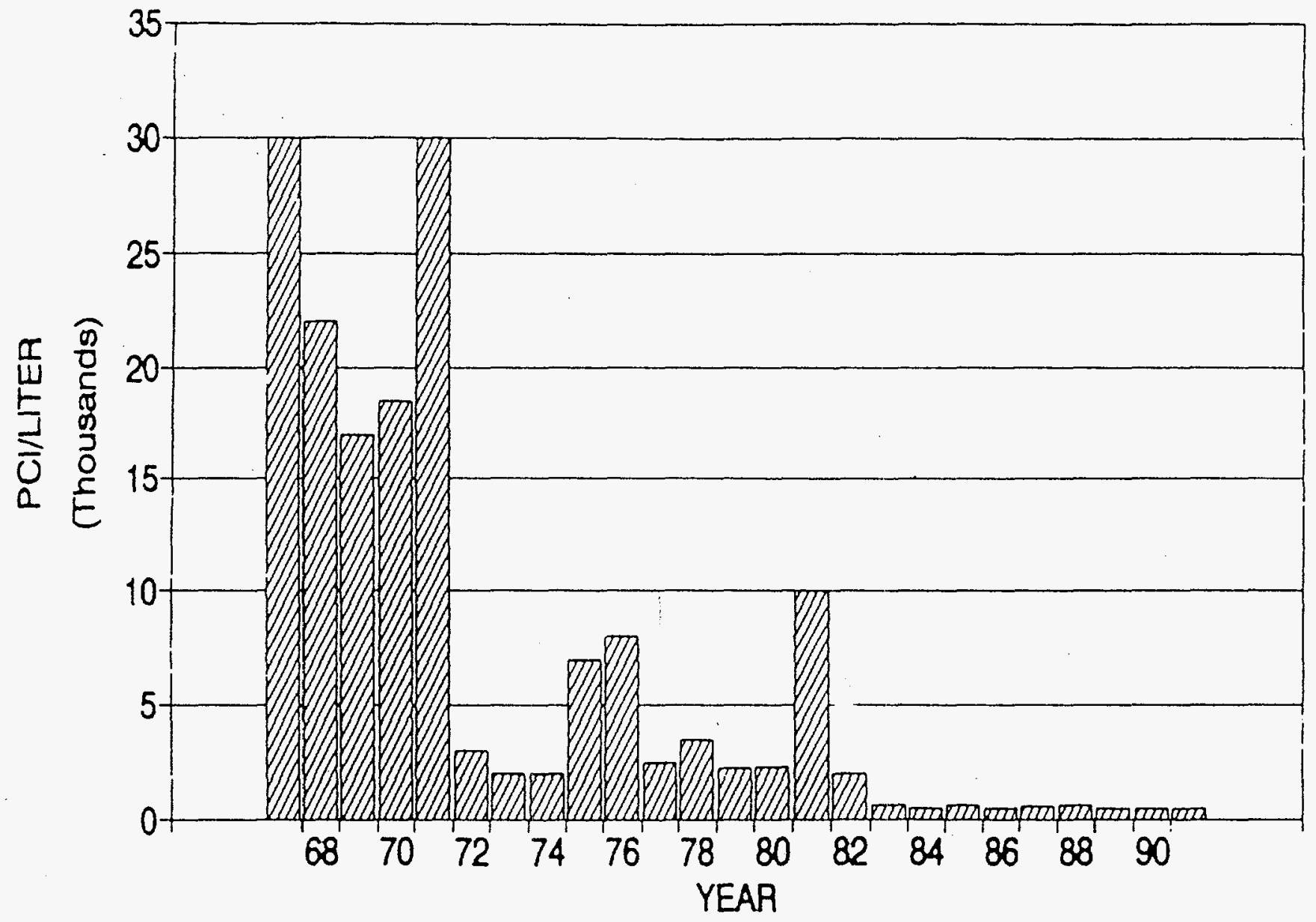

Figure 5-10. $\mathrm{H}-3$ at Springville Dam.

conducted in 1968, 1969, 1970, 1979, and 1984. Direct radiation levels at the SDA are routinely monitored by NYSERDA and the DEC during inspections. Much of the direct radiation observed during these inspections is attributable to the proximity of the main plant and a nearby drum-storage facility.

\section{Soil}

Soil samples are routinely taken on and around the SDA by NYSERDA and the DEC during the course of scheduled inspections. Additionally, soil samples are taken in support of construction projects such as the recent slurry wall project. Exploratory soil borings were taken in preparation for the excavation carried out at the SDA. Borings taken in preparation for the slurry wall project indicated elevated levels of tritium in several borings located to the west of Trench 14 .

Surveys of previously installed slump-monitoring stakes were undertaken during the fall of 1991 , by NYSERDA, in order to determine the overall rate of soil movement on the north slope of the SDA. Preliminary results indicate a soil movement rate not greater than six inches in 20 years. This result, coupled with recent stabilization efforts, such as hydroseeding of the north slope, should assure slope stability for the immediate future. 


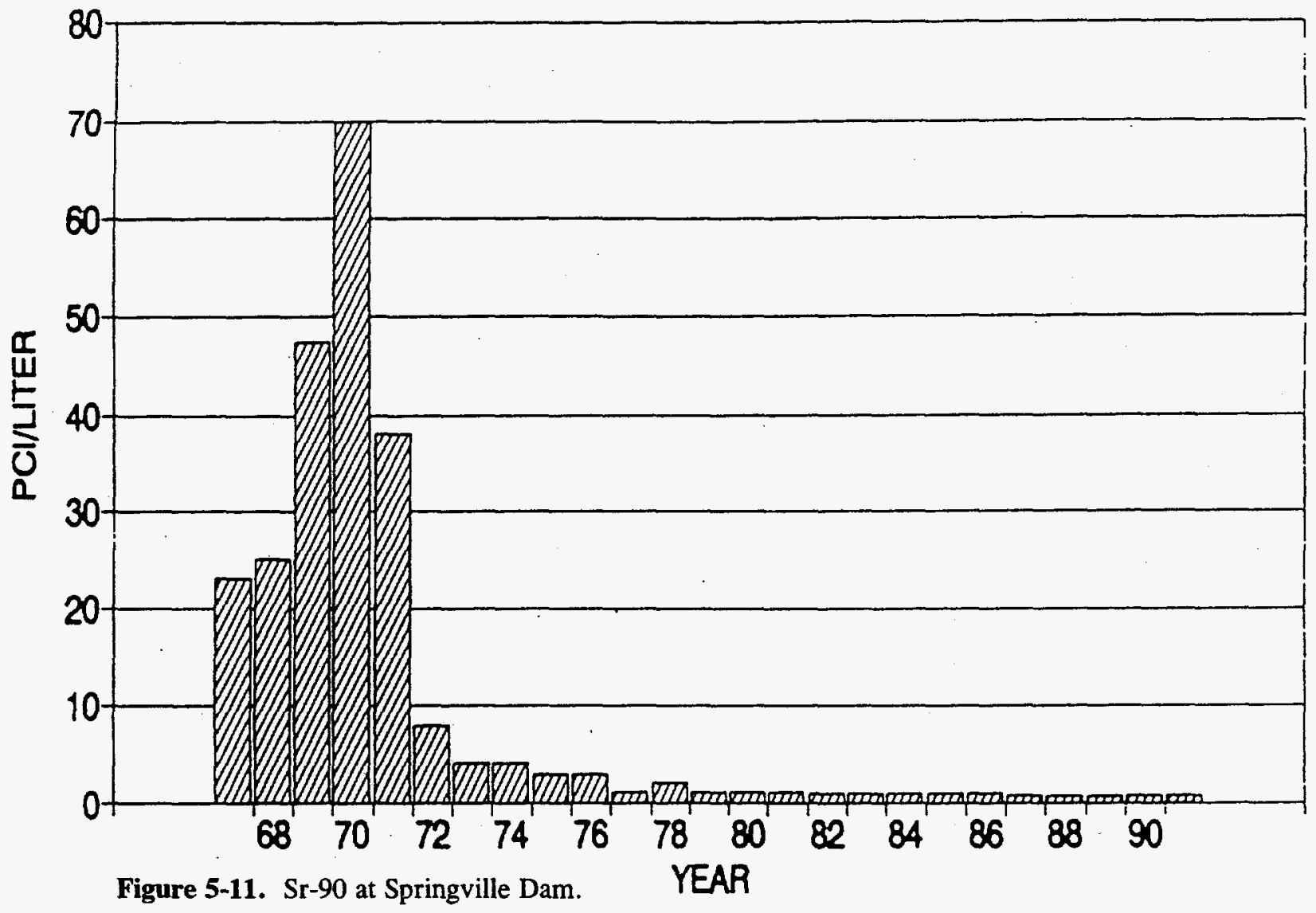

\section{Biota}

Two local dairy farms are monitored on a monthly basis for radionuclides in milk. Area farm produce and venison are sampled on a yearly basis, and fish are now taken from the Cattaraugus Creek near Springville on a semiannual basis and monitored for radionuclide content.

\section{SUMMARY}

Prior to 1975, the monitoring of the SDA was carried out solely as part of the monitoring of the NFS plant at West Valley. Aside from occasional monitoring of water levels in the covered trenches and pump-outs of open trenches, the SDA received little individual scrutiny. Releases of radionuclides to the environment were primarily attributable to the operations of the NFS plant. This has resulted in some confusion with respect to the record of the SDA prior to 1975.

In 1975, significant problems at the SDA developed due to the "overflowing" of Trenches 4 and 5 and the subsequent pumpings needed to prevent more overflow incidents. At no time during or after 1975 did the levels of radionuclides released by the SDA approach the levels released by the NSF plant prior to its closing in 1971. The 1975 overflow incident did increase regulatory awareness of the potential for contaminant migration through ground and surface water from the SDA and resulted in the establishment of several monitoring stations designed to detect the entrance of contaminants from the SDA into Erdman Brook. Results were consistently negative and the State Health Department no longer consistently monitors these stations. The milk, produce, and animal flesh monitoring programs have provided better estimates of dose pathways to the general population. However, the effects of the SDA are difficult to separate from those of the Fuel Reprocessing Plant. 
The newly installed ground water monitoring wells and piezometers at the SDA have eliminated the most serious deficiency in the environmental monitoring program for the SDA providing a more reliable method of estimating the extent of ground water migration of radionuclides from the SDA. Additionally, the new monitoring program serves as a preparation for remedial actions and eventual closure of the SDA.

Releases of radionuclides from the SDA have been trivial when compared to the Fuels Reprocessing Plant. This makes a precise evaluation of the SDA's effect on the environment difficult. The releases from the SDA have not exceeded regulatory standards at the site boundary and, to 1995, the SDA has not posed a significant threat to human health and safety. The SDA has required active maintenance and remedial measures to ensure that releases are kept to a minimum. Further work must be done to stabilize the site, especially with respect to water levels in the SDA trenches.

Disposal records for the SDA are being examined in depth as part of a New York State Energy Research and Development Authority project to inventory wastes in Trenches 12 through 14 . This inventory will provide a much needed supplement to the 1972 DEC report for Trenches 1 through 11.

NYSERDA (or New York State) has focused its efforts on minimizing water infiltration through an active maintenance program, establishing a comprehensive environmental monitoring program, and collecting site-specific data to allow for decisions to be made on eventual stabilization and closure of the SDA. The strategy for closure of the SDA will be developed as part of an ongoing (joint DOE/ NYSERDA) effort to review the impacts from all waste management areas at the Center including the SDA. 


\section{REFERENCES}

5-1. W. J. Kelleher and E. J. Michael, "Low-Level Radioactive Waste Burial Site Inventory for the West Valley Site," Cattaraugus County, New York, New York State Department of Environmental Conservation, 1973.

5-2. United States Department of Energy, Western New York Nuclear Service Center Study, TID28-905, United States Department of Energy, 1978.

5-3. J. P. Duckworth, "Compilation of West Valley Solid Radioactive Waste Burial Operations," Fuel Services, Inc., Unpublished Report, February 16, 1981.

5-4. U.S. Department of Commerce, Climatography of the United States, No. 60 - Climate of New York, U.S. Department of Commerce, National Climatic Data Center, Asheville, North Carolina, 1977.

5-5. J. R. Albanese, S. L. Anderson, R. H. Fakundiny, S. M. Potter, W. B. Rogers, and L. F. Whitbeck, "Geologic and Hydrologic Research at the Western New York Nuclear Service Center," West Valley, New York, Final Report, August 1982 - December 1983, New York State Geological Survey for the U.S. Nuclear Regulatory Commission, NUREG/CR-3782, June, 1984.

5-6. New York State Department of Health, Environmental Radioactivity in New York State, 1968.

5-7. United States Environmental Protection Agency, EPA-520/3-74-001, 1974.

5-8. $\quad$ New York State Department of Health, 1989 Annual Report of Environmental Radiation Levels in New York State.

5-9. D. H. Denham, R. D. Stenner, P. A. Eddy, R. E. Jaquish, J. V. Ramsdell, Jr., "Recommendations to the NRC for Review Criteria for Alternative Methods of Low-Level Radioactive Waste Disposal, by Pacific Northwest Laboratory, " Richland, Washington, PNL 6553 for U.S. Nuclear Regulatory Commission, NUREG/CR5054, 1988.

5-10. T. J. Nicholson and R. D. Hurt, "Information on the Confinement Capability of the Facility Disposal Area at West Valley, New York," U.S. Nuclear Regulatory Commission, Washington, DC, NUREG-1164, 1985.

5-11. A. J. Weiss and P. Columbe, "Evaluation of Isotope Migration - Land Burial, Status Report through September 30, 1977," Brookhaven National Laboratory, Upton, New York, NUREG-GR-1289, BNL-NUREG-51143, 1980.

5-12. D. B. Anderson, Response to Questions Regarding Solid Waste Management Units Located at the Western New York Nuclear Service Center, from the Energy Authority to the U.S. Environmental Protection Agency, March 30, 1988. 
5-13. Engineering Science, Liverpool New York Groundwater Monitoring Program West Valley Low-Level Radioactive Waste Disposal Area, September, 1989. 


\section{OTHER REFERENCES}

Anderson, D. B., Response to Questions Regarding Solid Waste Management Units Located at the Western New York Nuclear Service Center, from the Energy Authority to the U.S. Environmental Protection Agency, March 30, 1988.

Bergeron, M. P., W. M. Kappel, and Richard M. Yager, Geohydrologic Conditions at the Nuclear Fuels Reprocessing Plant and Waste Management Facilities at the Western New York Nuclear Service Center, Cattaraugus County, New York, U.S. Geological Survey, Water-Resource Investigations Report 85-4185, Ithaca, New York, 1987.

Duckworth, J. P. , M. J. Jump, and B. E. Knight, 1974. Low-Level Radioactive Waste Management Research Project, Final Report, Nuclear Fuel Services, Inc., Report to New York State Atomic and Space Development Authority.

Duckworth, J. P., Compilation of West Valley Solid Radioactive Waste Burial Operations, 1981.

Ecology and Environment, Inc., RFI Work Plan for NYSERDA - Maintained Portions of the Western New York Nuclear Service Center, May 1992.

Kelleher, W. J., Addendum to Low-Level Radioactive Waste Burial Site Inventory for the West Valley Site, Cattaraugus County, New York, New York State Department of Environmental Conservation, 1979.

Kelleher, W. J., Environmental Surveillance around a Nuclear Fuel Reprocessing Installation 1965-67 Radiological Health Data and Reports, 10:329-339, New York State Department of Health, 1969.

Kelleher, W. J., and E. J. Michael, Low-Level Radioactive Waste Burial Site Inventory for the West Valley Site, Cattaraugus County, New York, New York State Department of Environmental Conservation, 1973.

New York State Department of Environmental Conservation, Bureau of Radiation, Annual Report of Environmental Radiation in New York State, 1975.

New York State Department of Health, Bureau of Environmental Radiation Protection, 1986 Annual Report of Environmental Radiation Leveis in New York State.

New York State Energy Research and Development Authority, Summary of Information Relating to WNY Nuclear Services Center Cesium Prong, 1993.

U.S. Department of Energy, Environmental Assessment for Disposal of Project Low-Level Waste, West Valley Demonstration Project; Part 1, Environmental Assessment, U.S. Department of Energy, West Valley Project Office, West Valley, New York DOE/EA - 0295, 1986. 
West Valley Nuclear Services, Inc., West Valley Demonstration Site Environmental Report for Calendar Year 1990, May 1991, U.S. Contract DE-AC07-81NE44139. 


\title{
CHAPTER 6
}

\section{Environmental Summary of the Barnwell, South Carolina Low-Level Radioactive Waste Disposal Site}

\author{
INTRODUCTION
}

\section{Background}

A commercial low-level radioactive waste disposal facility near Barnwell, South Carolina has been operated by Chem-Nuclear Systems, Inc. since 1971. The site is owned by the State of South Carolina and is leased to Chem-Nuclear by the State Budget and Control Board.

South Carolina is an Agreement State, with authority delegated from the U.S. Nuclear Regulatory Commission (NRC). Most activities at the site are regulated by the South Carolina Department of Health and Environmental Control. The site operator holds a license from the state for possession and disposal of source and byproduct material as well as a license from NRC for possession and disposal of special nuclear material.

\section{Location}

The Barnwell site is located about $8 \mathrm{~km}$ (5 miles) west of the town of Barnwell, South Carolina (Figure 6-1). The site (Figure 6-2) is adjacent to the closed Allied General Nuclear Services Barnwell Fuel Facility on the west; International Paper Company on the north; Osborne Road on the south; Barnwell County Road 585 on the east; and St. Paul Church at the southeast corner. The site is approximately $0.3 \mathrm{~km}(0.2 \mathrm{mi})$ from the easterly boundaries of the U.S. Department of Energy Savannah River Site and is $0.8 \mathrm{~km}(0.5 \mathrm{mi})$ from South Carolina Highway 64. The facility is an irregular polygon covering 121 hectares (300 acres) of land measuring roughly $1,500 \mathrm{~m}(4,950 \mathrm{ft})$ in the north-south direction and $750 \mathrm{~m}(2,475 \mathrm{ft})$ in an east-west direction.

\section{Facility}

Waste disposal was initiated at the Barnwell site in 1971 . Approximately $75 \%$ of the waste volume received at the site is fuel cycle waste. All other generators-including medical, industrial, academic, and research facilities-generate the remaining waste volume.

Class A, B, and C wastes (as defined in 10 CFR 61) are accepted for disposal at the site. Approximately $97 \%$ of the volume of waste received at the site is Class A waste. The majority of the remaining $3 \%$ is Class $\mathrm{B}$ waste with less than $1 \%$ by volume being Class $\mathrm{C}$ waste. The Class $\mathrm{C}$ waste, however, composes the majority of the radioactivity in curies of the waste received. 


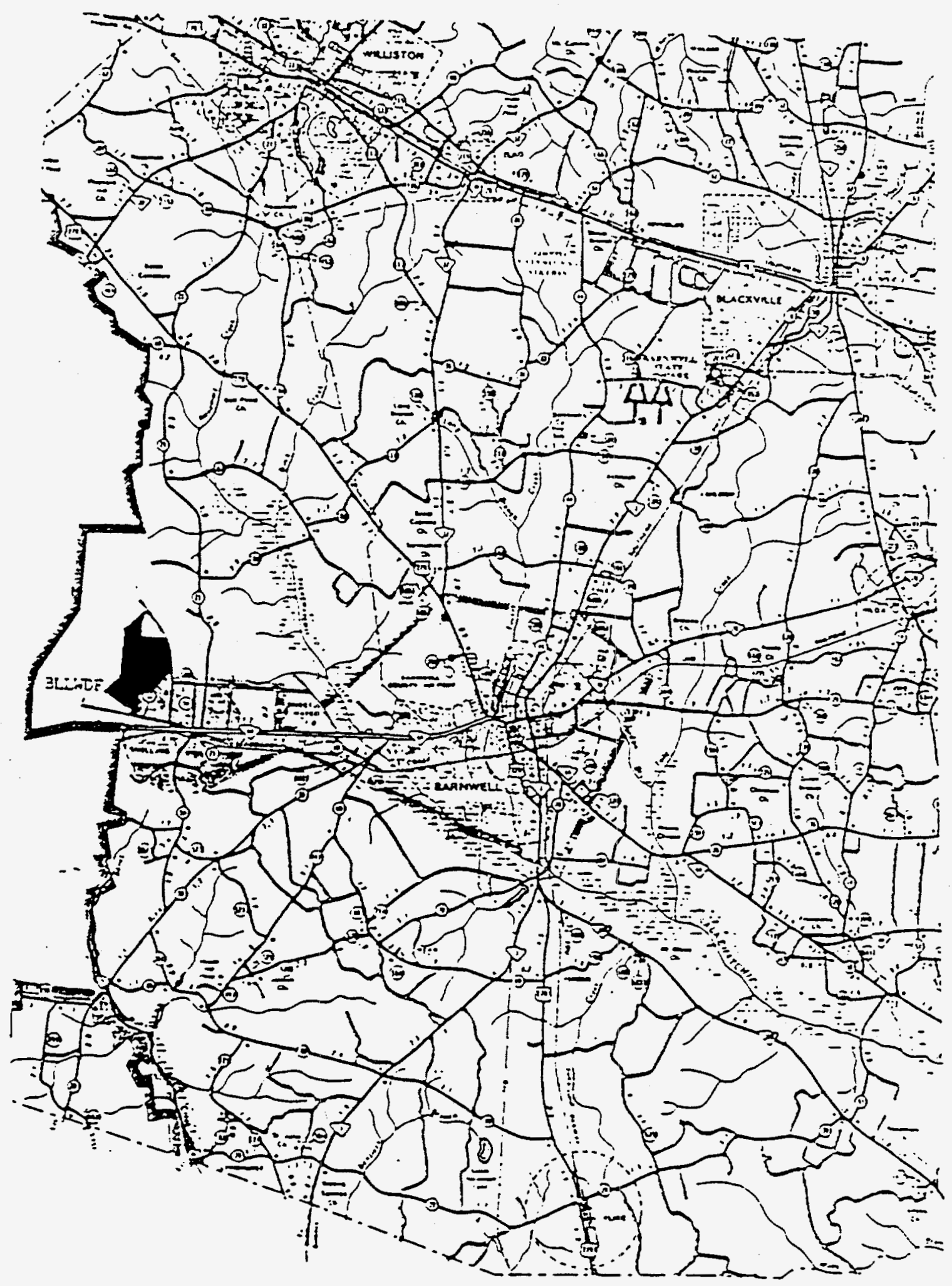

Figure 6-1. Location of Barnwell site. 


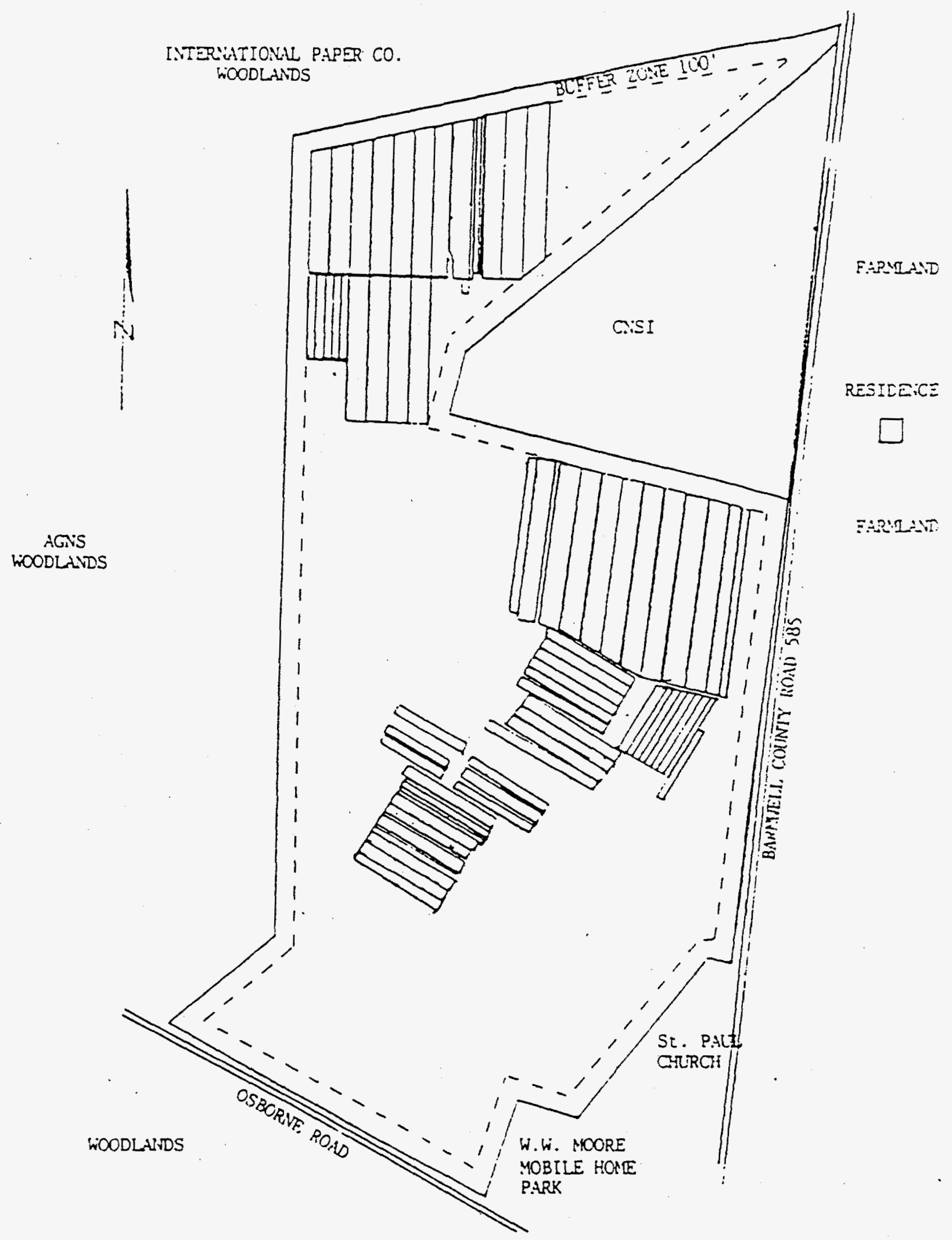

Figure 6-2. Plan view of the Barnwell site showing adjacent land owners. 
Shipments received at the site are designated as non-exclusive use or exclusive use shipments. Non-exclusive use shipments may contain packages which are not radioactive in addition to packages which are radioactive. In addition, the packages may be transferred from one truck to another by the carrier. Radiation levels for non-exclusive use shipments are limited to $200 \mathrm{mRem} / \mathrm{hr}$ at any point on the external surface of each package, $10 \mathrm{mRem} / \mathrm{hr}$ at any point on the external surface of the vehicle, and $2 \mathrm{mRem} / \mathrm{hr}$ in any space normally occupied by the driver. Exclusive use shipments are shipments which contain only radioactive material. The material must remain in the truck in which it is loaded until it reaches its destination. Radiation levels for exclusive use shipments are limited to 1,000 $\mathrm{mRem} / \mathrm{hr}$ on contact with the surface of the package (closed vehicle), $200 \mathrm{mRem} / \mathrm{hr}$ at any point on the external surface of the vehicle, $10 \mathrm{mRem} / \mathrm{hr}$ at 2 meters from the external surface of the vehicle and $2 \mathrm{mRem} / \mathrm{hr}$ at any space normally occupied by the driver. Inspections performed by the state's resident inspectors $^{6-1}$ and Chem-Nuclear personnel of $100 \%$ of the shipments confirm radiation levels of the transport vehicles are below these regulatory limits.

Shipments enter and leave Barnwell County via routes SC-41 and US-278, SC-3, SC-64, and SC-70 which are two lane routes through rural areas. By using these routes, the shipments are not carried through the center of the town of Barnwell. Vehicles carrying shipments of radioactive waste to the Barnwell site travel routes which do not pass through or near heavily populated areas unless there is no practical alternative.

Waste received at the site is packaged to meet U.S. Department of Transportation requirements in Title 49 of the Code of Federal Regulations. In addition, certain other specific requirements are placed by license condition on waste received at the site. The waste is to be received and buried in closed containers. The burial containers must have less than $0.5 \%$ free standing liquid (High Integrity Containers are allowed to have up to $1 \%$ free standing liquid). The burial containers must have appropriate lifting devices.

The majority of the containers received at the site are free of removable contamination on their surfaces. This greatly reduces the potential for airborne contamination. Occasionally a container is received which has removable contamination on its exterior. Special procedures which prevent the spread of contamination are used to offload and bury these containers.

Figure 6-3 illustrates a typical disposal trench. Three trench designs are used. The Type A trenches are for Class A waste only and are generally $300 \mathrm{~m}(1,000 \mathrm{ft})$ long, $30 \mathrm{~m}(100 \mathrm{ft})$ wide, and $7 \mathrm{~m}(22 \mathrm{ft})$ deep.

Class B and C wastes are segregated from Class A waste. Type B trenches are for both Class B

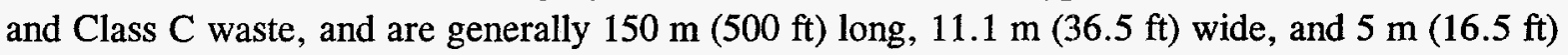
deep. Concrete structural overpacks are used in Type B trenches to allow disposal of polyethylene High Integrity Containers. Slit trenches are used for Class $C$ waste which have high radiation levels on the exterior of the package. Slit trench length varies according to the location. The trenches are $7 \mathrm{~m}$

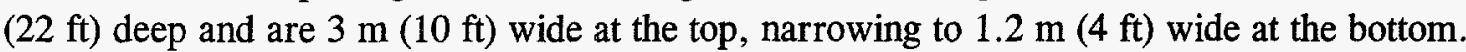




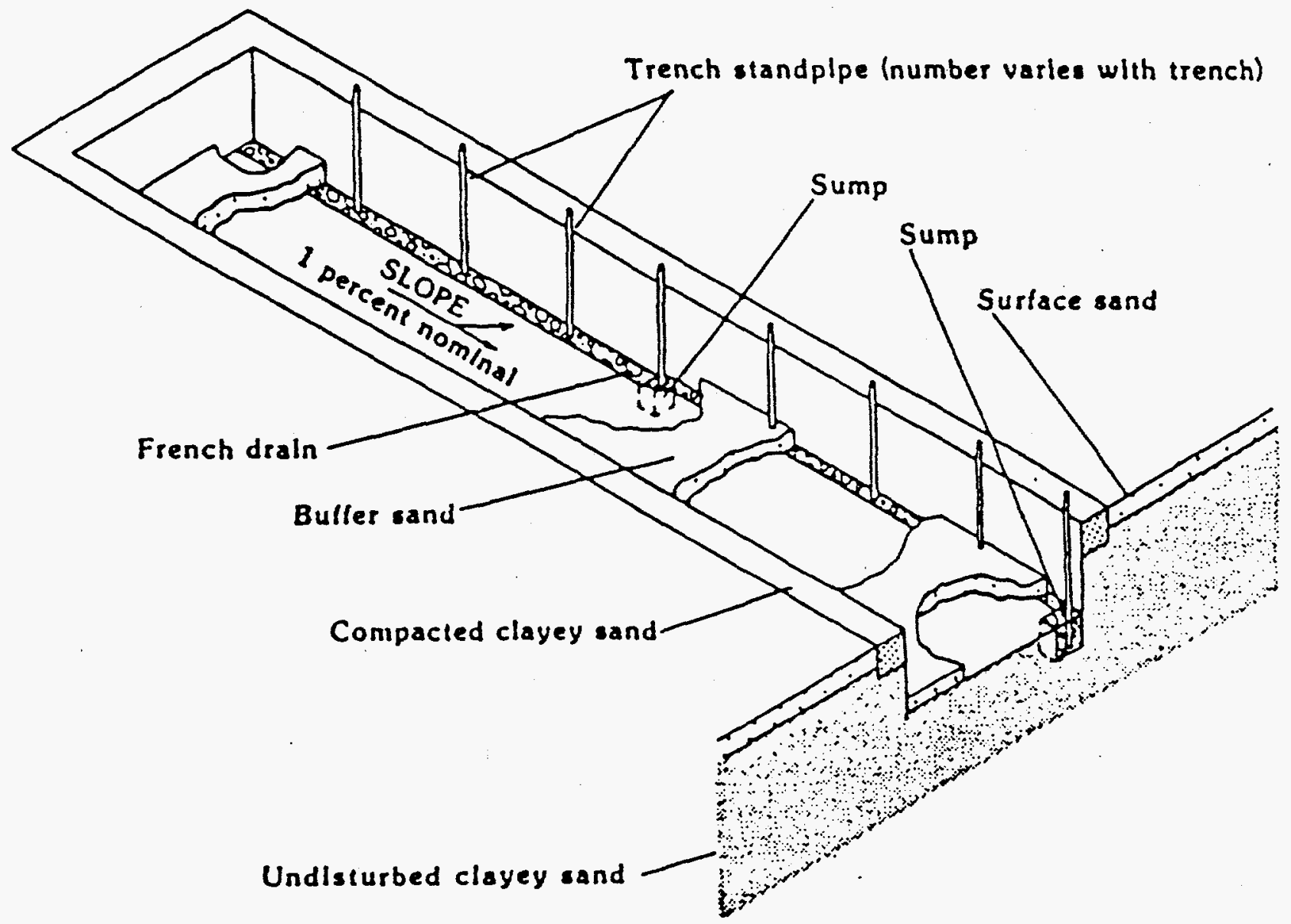

Figure 6-3. Typical disposal trench at the Barnwell site.

After waste has been placed and covered in the slit trench, a $15 \mathrm{~cm}(6 \mathrm{in}$.) thick concrete intrusion barrier is constructed over the trench. All trenches are required to have a minimum of $2.4 \mathrm{~m}(8 \mathrm{ft})$ of separation between adjacent trench and a minimum of $1.5 \mathrm{~m}(5 \mathrm{ft})$ of separation between the trench floor and the highest recorded level of the water table in order to prevent water infiltrating from below into a trench. The trench drainage system consists of a sand floor, French drain along one longitudinal wall, sumps, and standpipes.

\section{Disposal Volume}

During the first year of operation, approximately $1,400 \mathrm{~m}^{3}\left(50,000 \mathrm{ft}^{3}\right)$ of waste containing 160 TBq $(4,200 \mathrm{Ci})$ of byproduct material was accepted and disposed. The disposal rate rose steadily over the next nine years to the point where the annual rate reached over $63,000 \mathrm{~m}^{3}$ (over 2.2 million $\mathrm{ft}^{3}$ ) in 1979. Table 6-1 shows volumes of waste disposed. 
Table 6-1. Barnwell site burial volumes.

\begin{tabular}{|c|c|c|}
\hline \multirow[b]{2}{*}{ Year } & \multicolumn{2}{|c|}{ Volume $^{a}$} \\
\hline & $\left(\right.$ Feet $\left.^{3}\right)$ & $\left(\right.$ Meters $\left.^{3}\right)$ \\
\hline 1971 & $50,219.34$ & 1,422 \\
\hline 1972 & $159,933.47$ & 4,529 \\
\hline 1973 & $599,886.28$ & 16,987 \\
\hline 1974 & $624,759.55$ & 17,691 \\
\hline 1975 & $643,564.44$ & 18,224 \\
\hline 1976 & $1,393,587.55$ & 39,462 \\
\hline 1977 & $1,636,425.12$ & 46,830 \\
\hline 1978 & $2,220,519.72$ & 62,878 \\
\hline 1979 & $2,238,322.13$ & 63,383 \\
\hline 1980 & $2,444,810.72$ & 69,230 \\
\hline 1981 & $1,543,278.67$ & 43,701 \\
\hline 1982 & $1,228,200.83$ & 34,779 \\
\hline 1983 & $1,240,668.21$ & 35,132 \\
\hline 1984 & $1,231,715.28$ & 34,878 \\
\hline 1985 & $1,214,422.99$ & 34,388 \\
\hline 1986 & $1,053,791.68$ & 29,840 \\
\hline 1987 & $958,275.82$ & 27,135 \\
\hline 1988 & $931,974.01$ & 26,391 \\
\hline 1989 & $1,103,299.56$ & 31,242 \\
\hline 1990 & $788,031.88$ & 22,315 \\
\hline 1991 & $789,082.85$ & 22,344 \\
\hline 1992 & $828,750.74$ & 23,467 \\
\hline 1993 & $605,443.07$ & 17,144 \\
\hline Total & $25,528,962.76$ & 722,904 \\
\hline
\end{tabular}

a. Values include waste volumes, pallets under waste packages, waste generated during site operations and waste received by approved exemptions. 
By late 1979 , the Barnwell site was the most heavily used site in commercial radioactive waste disposal history and, for a brief time, was the only operating commercial low-level radioactive waste disposal site in the United States. In October of 1979, when the monthly waste acceptance rate had risen to over $7,000 \mathrm{~m}^{3}$ (about $250,000 \mathrm{ft}^{3}$ ) implying an annual rate of $68,000 \mathrm{~m}^{3}\left(2.4\right.$ million $\mathrm{ft}^{3}$ ), the Governor of South Carolina announced that the monthly acceptance would have to be reduced to just over $2,800 \mathrm{~m}^{3}\left(100,000 \mathrm{ft}^{3}\right)$ by October 31,1981 . The 1980 disposal rate was reduced due to restriction on the annual volume of waste received. Waste received through 1980 totaled $323,523 \mathrm{~m}^{3}$ $\left(11,424,900 \mathrm{ft}^{3}\right.$ ). The total volume received through 1993 is almost $723,000 \mathrm{~m}^{3}$ (about $25,500,000 \mathrm{ft}^{3}$ ).

Through 1993 , wastes containing about $272,000 \mathrm{TBq}(7,137,000 \mathrm{Ci})$ of radioactivity have been disposed. The decay corrected radioactivity through 1993 is approximately $113,200 \mathrm{TBq}(2,971,000$ $\mathrm{Ci}$ ). In addition, about 15.3 million $\mathrm{kg}$ (33.6 million $\mathrm{lb}$ ) of source material and approximately $3,056 \mathrm{~kg}$ (6,732 pounds) of special nuclear material have been disposed through 1993.

\section{Stabilization and Closure}

Individual trenches are closed and capped with compacted on-site clay materials as they are filled. The conceptual topography of the site at closure was identified in the early 1980's and trench surfaces have been completed near those grades since that time. Due to the migration of tritium in the groundwater from some of the early disposal trenches, enhanced caps are being installed on the early disposal trenches. These enhanced caps have a cross section as shown in Figure 6-4.

In 1991, an area of approximately 5 hectares (12.5 acres) was covered and in 1993, an area of approximately 4 hectares (10 acres) was covered with an enhanced cap. Plans are underway to install another enhanced cap over approximately 10 hectares ( 25 acres) of disposal trenches during 1994. The enhanced caps virtually eliminate infiltration into the trenches thereby eliminating the water source driving the contaminants. ${ }^{6-2}$

After the completion of the third cap, all disposal trenches completed through 1982 with significant quantities of tritium will be covered. Enhanced caps may not be necessary on the later disposal trenches for the following reasons, but this would require substantial evaluation. High integrity containers have been used for high concentration wastes (waste with radionuclide concentrations of one microcurie per cubic centimeter or greater of radionuclides with five year or longer half-lives) since 1981. Improved solidification media were required in 1983 with the implementation of the NRC Branch Technical Position on Waste Form. Also in 1983, 10 CFR Part 61 required more detailed characterization and classification of waste and stability requirements for Class $\mathrm{B}$ and $\mathrm{C}$ waste materials. The lower concentration Class $\mathrm{A}$ wastes were also required to be segregated from the Class B and C waste materials.

After the remaining closure activities are completed, the site will have gently sloping surfaces of native grass vegetation. Surface water runoff will be directed towards an on-site retention pond. Maintenance of the site surface and environmental monitoring will continue through the institutional control period. 




Figure 6-4. Barnwell site enhanced cap cross section.

\section{SITE}

\section{Topography}

The Barnwell site is in the Upper Coastal Plain Physiographic Province, with flat to gently-rolling topography at elevations averaging 74 to $80 \mathrm{~m} \mathrm{(243} \mathrm{to} 262 \mathrm{ft}$ ) above mean sea level. Drainage on and around the site is considered good with the exception of undrained "sinks" or "Carolina Bays." Carolina Bays are circular depressions of undetermined origin which occur throughout the area. Several Carolina Bays exist on the disposal site and represent areas which are generally unsuitable for waste disposal under existing conditions.

\section{Climate}

The climate of the Barnwell site is mild and relatively humid, with mean temperatures ranging from $9^{\circ} \mathrm{C}\left(48^{\circ} \mathrm{F}\right)$ in January to $27^{\circ} \mathrm{C}\left(81^{\circ} \mathrm{F}\right)$ in July. The precipitation averages $108 \mathrm{~cm}(42.7 \mathrm{in}$.) per year. Historical rainfall data are given for Barnwell County in Table 6-2. Ice storms and damaging winds are rare. Measurable snow occurs at approximately 10 year intervals and usually does not remain for great periods of time. The largest recorded snowfall for the area was $45.7 \mathrm{~cm}$ (18 in.) over 
Table 6-2. Rainfall for Barnwell County.

\begin{tabular}{lc} 
Year & Total inches \\
\hline 1984 & 48.43 \\
1985 & 44.04 \\
1986 & 33.21 \\
1987 & 42.10 \\
1988 & 36.25 \\
1989 & 49.53 \\
1990 & 45.60 \\
1991 & 54.44 \\
1992 & 53.66 \\
\end{tabular}

a two-day period in February 1973. Freeze/thaw cycling of the soil, waste, and disposal containers are not a concern since less than one third of the winter days have a minimum temperature below freezing.

\section{Land Use}

A buffer zone of $30 \mathrm{~m}(100 \mathrm{ft})$ is provided within the outermost perimeter fencing around the 95 hectare ( 236 acre) exclusion area. Approximately 35 hectares $(86.6$ acres) of the site had been used for disposal of waste through 1993 and approximately 15 hectares ( 36.7 acres) remain for disposal of waste.

The site is bounded by woodlands on the north, west, and south, and farmland on the east. The nearest residence is less than one-tenth of a mile from the site boundary.

The 1990 estimated population of Barnwell County was 20,293 in the 1,444 square kilometers (553 square mile) area giving a population density of about 37 per square mile. Approximately onethird of the population of the county is in the city of Barnwell. During the period between 1980 and 1986 , the county experienced a $5.7 \%$ population growth. During the period between 1986 and 1990 , the county experienced a $3.4 \%$ population decline. Manufacturing represents over one-third of the county's employment. Farming provides less than $15 \%$ of the county's employment.

\section{Geology}

The site is near the eastern edge of the Aiken Plateau portion of the Atlantic Coastal Plain on a layer approximately $300 \mathrm{~m}(1,000 \mathrm{ft})$ thick of southeasterly-dipping, loose, unconsolidated sediments of upper Cretaceous, Tertiary, and Quaternary ages (Figure 6-5) which unconformably overlie an older, well-consolidated Triassic Age basement. The Quarternary age soils, which immediately underlay the 




Figure 6-5. Stratigraphic and lithographic interpretation of the Barnwell site. 
topsoil, consist of loose to moderately dense fine and silty sands and range from a few centimeters to meters in thickness. Underlying this sandy layer is the Tertiary System which consists of the Hawthorn, Barnwell, McBean, and Congaree Formations. The Hawthorn Formation, which is about $8 \mathrm{~m}$ (26 ft) thick, consists of tan to reddish color sandy clay with patches of kaolinite material disseminated throughout in the upper part of the formation, and yellow clayey sand to dark red sandy clay at the base of the formation. The Barnwell Formation underlies the Hawthorn Formation, is approximately $15 \mathrm{~m} \mathrm{(50} \mathrm{ft)} \mathrm{in} \mathrm{thickness,} \mathrm{and} \mathrm{is} \mathrm{composed} \mathrm{of} \mathrm{brown,} \mathrm{maroon,} \mathrm{and} \mathrm{red} \mathrm{clayey} \mathrm{sand}$ which changes to yellow sand near the contact with the McBean Formation. The McBean Formation is about $35 \mathrm{~m}$ (115 ft) thick and consists of white, tan, brown, and yellow clays interbedded with medium to course quartz sand. Beds of McBean Formation limestone occur east and southeast of the burial site. The Congaree Formation, with a thickness of about $44 \mathrm{~m}(144 \mathrm{ft})$, provides the interface with the Cretaceous system and consists of sands to sandy gravel.

The Cretaceous System includes the Ellenton Formation and the Middendorf Formation. The Ellenton Formation consists of an upper clay unit composed of dark grey to black clay and sandy clay, and a lower sand unit composed of medium to course white and grey sand with streaks of brown clay and quartz gravel. The Middendorf Formation consists of course sand and gravel interbedded with diversely colored clay beds or lenses. Figure 6-5 provides a stratigraphic and lithographic interpretation of a well at the Allied General Nuclear Services Plant adjacent to the Barnwell site.

\section{Surface Water}

The Barnwell site is geographically located between the Salkehatchie River on the east and the Savannah River on the west. The Salkehatchie, at $4.1 \mathrm{~km}(2.5 \mathrm{mi})$, is the closest river, but the site is in the surface drainage area of a Savannah River tributary, called Lower Three Runs Creek. There is no flowing stream on the site. The nearest seepage point, named Mary's Creek, is $1 \mathrm{~km}(0.6 \mathrm{mi})$ to the south and originates as a small constant flowing stream. Mary's Creek is a tributary of Lower Three Runs Creek and part of its 470 square kilometer (180 square mile) watershed area.

Surface run-off from the site is directed away from the trenches and is collected for infiltration and evaporation in two surface collection ponds, formally a Carolina Bay, located along the western boundary of the site. Active trenches are constructed with a slight upward grade to the edge of the trench to prevent surface water from flowing into the trenches. Water which collects in the open trenches is allowed to evaporate and is not transferred to the surface collection ponds except under extreme conditions of heavy rainfall, and then only after it is monitored to assure no elevation in radioactivity.

The closest reach of the Savannah River is approximately $22.5 \mathrm{~km}$ (14 mi) southwest of the site. Downstream, the Savannah River is used for sport fishing and pleasure boating. The Savannah River is a drinking water supply for Port Wentworth, Georgia, providing for a consumer population of about 20,000, and at Hardeeville, South Carolina, providing for a consumer population of approximately 80,000 . There is commercial shipping on the $27 \mathrm{~m}(90 \mathrm{ft})$ wide, $3 \mathrm{~m}(10 \mathrm{ft})$ deep channel maintained between Augusta and Savannah, Georgia. 


\section{Ground Water}

The ground water table at the site is contained within the Hawthorn Formation and ranges in depth from about 9 to $18 \mathrm{~m}$ ( 30 to $60 \mathrm{ft}$ ) with a mean of about $12 \mathrm{~m}(40 \mathrm{ft})$. The ground water in the area is acidic with a pH ranging from 4.8 to 6.5 and is therefore corrosive to metals.

There are no potable water wells in service as drinking water wells on the site. There are no users of ground water directly downstream of the site. The town of Barnwell is the nearest municipal user of ground water. The water is withdrawn from fairly-permeable zones within the McBean

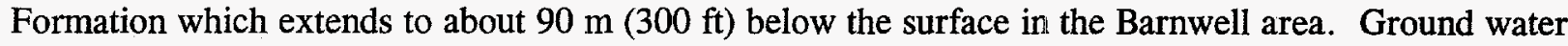
at the site does not flow toward the town of Barnwell. Water from the underlying Cretaceous Middendorf Formation forms the principal ultimate source of potable water for the area.

\section{Ecology}

The Barnwell area is composed of habitats varying from very sandy, dry uplands to continuously flooded swamps. Organic matter thrives in the low-lying areas due to the supply of nutrients. The local vegetation includes wild grass, scrub oak, and pine. The area developed for the waste disposal facility was previously used for pulpwood production and agriculture.

The Carolina Bays support natural systems such as ponds, swamp forests, and herbaceous vegetation. These systems support animal populations including tree frogs, cricket frogs and other amphibians; several bird species, and small snakes. Larger predators which include hawks, owls, snakes, weasels, and foxes, prey on cotton rats and amphibians. The Barnwell county ecosystem supports over 68 species of land animals and birds. A list of some of the mammals and birds found in Barnwell County are given in Table 6-3.

\section{ENVIRONMENTAL MONITORING}

Environmental monitoring is performed at the Barnwell site by both Chem-Nuclear and the South Carolina Department of Health and Environmental Control. The monitoring programs include ground water, surface water, air, precipitation, soil, sediments, vegetation, and direct radiation. Sample frequency is continuous for air and external gamma radiation, quarterly for groundwater and annually for all other samples. Groundwater samples are collected by Chem-Nuclear and are split for analysis by both Chem-Nuclear and by the state. All other sampling is performed independently and results are compared for consistency.

\section{Ground Water}

Figure 6-6 shows the locations of boundary monitor stations which include well clusters (WB-) screened at approximately 12,15 , and 18 meter depths. The depths of the shallow wells vary from 11 to $12 \mathrm{~m} \mathrm{(35}$ to $40 \mathrm{ft}$ ). The depths of the intermediate wells vary from 12 to $15 \mathrm{~m} \mathrm{(40} \mathrm{to} 50 \mathrm{ft}$ ). The depths of the deep wells vary from 15 to $21 \mathrm{~m}$ ( 50 to $70 \mathrm{ft}$ ). 
Table 6-3. Biota found in Barnwell County.

Mammals

Common Name

Opossum

Eastern Cottontail

Gray Squirrel

Gray Fox

Raccoon

White Tail Deer

Bobcat

Beaver

Southern Flying Squirrel
Scientific Name

Didelphis marsupialis

Sylvilagus floridanus mallurus

Sciurus carolinensis carolinensis

Urocyon cinereoagenteus cinereoagenteus

Procyon lotor solatua

Odocoileus viginianus viginianus

Lynx rufus floridanus

Castor canadensis carolinensis

Claucomys volens saturatus

\section{Birds}

\section{Common Name}

Mallard Duck

Wood Duck

Turkey Vulture

Red-Tailed Hawk

Sparrow Hawk

Bobwhite

Morning Dove

Screech Owl

Common Crow

Carolina Wren

\section{$\underline{\text { Scientific Name }}$}

Anas platyrhynchos

Aix sponsa

Cathartes aura

Buteo jamicensis

Falco sparverius

Colinus virginianus

Enaidura asistica

Otus asio

Corvus brachyrhynchos

Thryothorus ludovicanus

Table 6-4 shows the concentrations of tritium for the boundary wells and for several streams (WC-) in the vicinity of the site. Liquid scintillation analysis is used to detect the presence of tritium. In 1992 , the average tritium level in boundary wells was just over $1,300 \mathrm{pCi} / \mathrm{L}(1,306 \mathrm{pCi} / \mathrm{L})$. The highest was just over $2,000 \mathrm{pCi} / \mathrm{L}(2,040 \mathrm{pCi} / \mathrm{L}) .^{6 \cdot 3}$

The boundary monitoring wells were installed in the early $1980 \mathrm{~s}$. These wells have been sampled routinely and the results of analyses have been reported to the South Carolina Department of Health and Environmental Control. These analyses show no significant concentrations of tritium above background. The records of the analyses are maintained by Chem-Nuclear and the Department. 


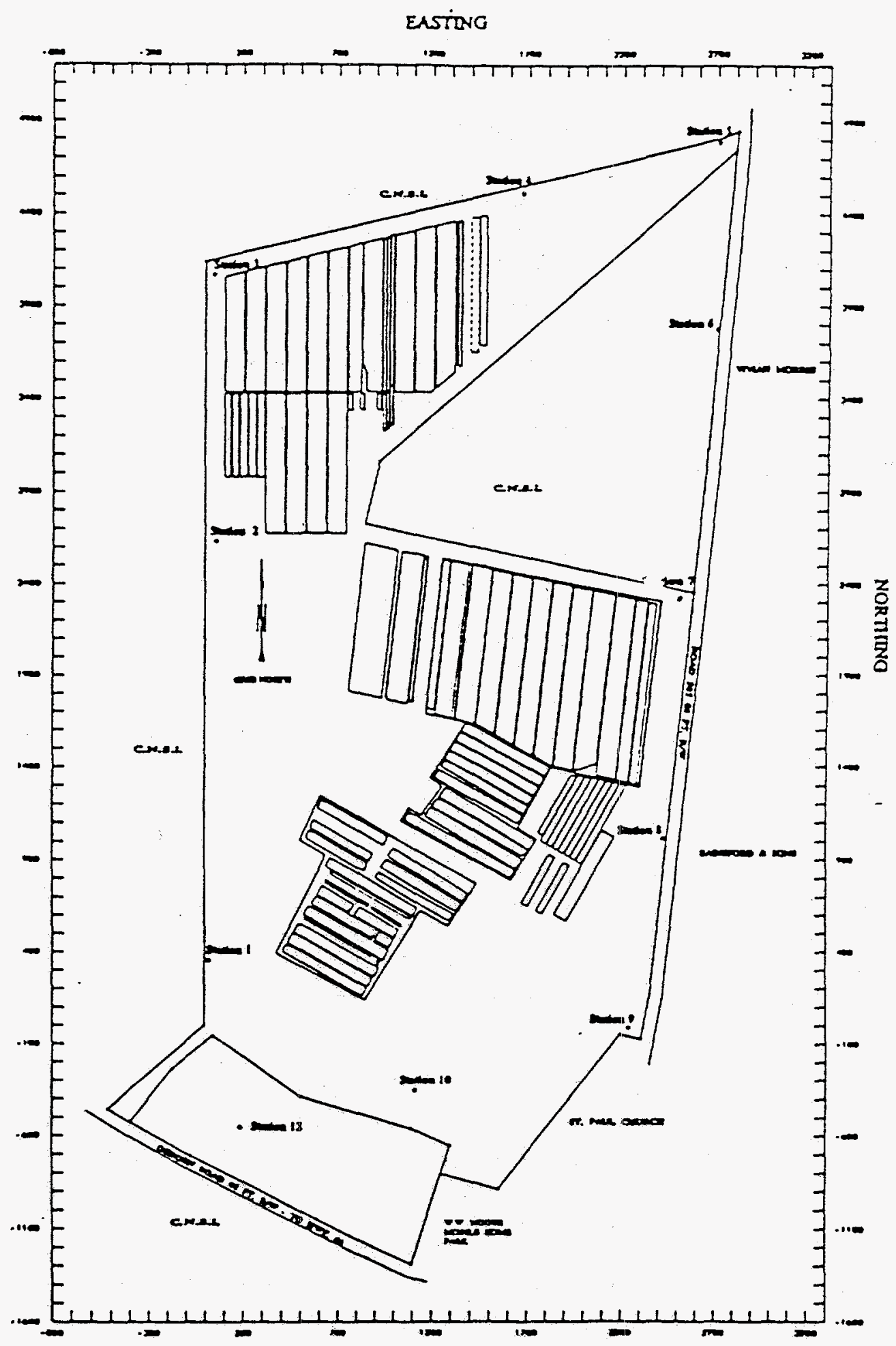

Figure 6-6. Plan view of the Barnwell site showing adjacent land owners/boundary sampling stations. 
Table 6-4. 1992 tritium monitoring data for ground waters and streams near the Barnwell site. ${ }^{6-3}$

\begin{tabular}{|c|c|c|c|}
\hline Well number & High & Average & Low \\
\hline WB-0101 & 1850 & 1441 & 875 \\
\hline WB-0102 & 1870 & 1450 & 760 \\
\hline WB-0103 & 1380 & 1098 & 640 \\
\hline WB-0201 & 1860 & 1560 & 880 \\
\hline WB-0202 & 1200 & 1050 & 790 \\
\hline WB-0301 & 1590 & 1350 & 970 \\
\hline WB-0401 & 1260 & 900 & 500 \\
\hline WB-0402 & 1870 & 1370 & 1000 \\
\hline WB-0403 & 2040 & 1400 & 780 \\
\hline WB-0501 & 1690 & 1350 & 650 \\
\hline WB-0502 & 1500 & 1250 & 800 \\
\hline WB-0601 & 1640 & 1225 & 870 \\
\hline WB-0602 & 1980 & 1567 & 1550 \\
\hline WB-0603 & 1930 & 1780 & 1550 \\
\hline WB-0701 & 1370 & 1114 & 796 \\
\hline WB-0702 & 1680 & 1618 & 1560 \\
\hline WB-0703 & 1680 & 1414 & 942 \\
\hline WB-0801 & 1600 & 1228 & 645 \\
\hline WB-0802 & 1670 & 1515 & 1330 \\
\hline WB-0901 & 1440 & 1115 & 826 \\
\hline WB-0902 & 1390 & 1129 & 628 \\
\hline WB-0903 & 1590 & 1145 & 830 \\
\hline WB-1001 & 1820 & 1461 & 1005 \\
\hline WB-1002 & 1284 & 964 & 450 \\
\hline WB-1003 & 1640 & 1159 & 600 \\
\hline WC-0001 (Duncannon Spring) & \multicolumn{3}{|c|}{$790 \pm 210^{a}$} \\
\hline WC-0002 (Railroad Track Spring) & \multicolumn{3}{|c|}{$1100 \pm 220^{\mathrm{a}}$} \\
\hline WC-0003 (Mary's Creek Spring) & \multicolumn{3}{|c|}{$975 \pm 210^{a}$} \\
\hline WC-0004 (Mary's Creek Grist Mill) & \multicolumn{3}{|c|}{$740 \pm 00 \mathrm{a}$} \\
\hline
\end{tabular}

a. These values are $\mathrm{pCi} / \mathrm{L} \pm$ one standard deviation. 


\section{Air}

Air is monitored by South Carolina Department of Health and Environmental Control at two locations, the western (upwind) side of the site and the eastern (downwind) side of the site at the boundary of the site (Figure 6-6). The filters are analyzed for total concentrations of alpha and beta particles and concentrations of specific gamma emitters.

Table 6-5 shows the average concentration of activity in the filters averaged over a one year period for 1992. Air samples are collected for 45 minutes each hour for periods of two weeks. The air is drawn through a particulate filter which is analyzed for gross alpha and beta activity and is analyzed for specific gamma emitters using a germanium detector. Concentrations of gamma-emitting radionuclides on air sampling filters are below the minimum detectable limits.

Precipitation is monitored at the two air sampling locations. The monitoring data for the two locations and a control location in Columbia, South Carolina is shown in Table 6-6. The table indicates that the gross beta and tritium concentration in the precipitation at the burial site are comparable to those in Columbia, South Carolina. The precipitation is analyzed for gross alpha and beta and for specific gamma-emitters using a germanium detector as well as for tritium using liquid scintillation detection.

\section{Radiation Levels}

Direct radiation is measured using thermoluminescent dosimeters (TLDs) at various locations in the vicinity of the site. Table 6-7 lists the annual radiation levels at several different locations around the state and near the site. As indicated by the data, operations at the site have little effect on the general radiation levels in the vicinity of the site.

Table 6-5. 1992 monitoring data for air near the Barnwell site. ${ }^{6-3}$

\begin{tabular}{lccc}
\hline & \multicolumn{3}{c}{$\begin{array}{c}\text { Gross beta } \\
\left(\mathrm{pCi} / \mathrm{m}^{3}\right)\end{array}$} \\
\cline { 2 - 4 } & High & Average & Low \\
\hline Columbia, SC & 0.417 & 0.024 & 0.004 \\
East Boundary & 0.370 & 0.028 & 0.003 \\
West Boundary & 0.410 & 0.043 & 0.004 \\
\hline
\end{tabular}


Table 6-6. 1992 precipitation monitoring data for the Barnwell site. ${ }^{6-3}$

\begin{tabular}{ccc}
\hline & (pCi/L \pm one standard deviation) \\
\hline & $\begin{array}{c}\text { Gross beta } \mathrm{pCi} / \mathrm{L} \\
\text { annual average }\end{array}$ & $\begin{array}{c}\text { Tritium } \mathrm{pCi} / \mathrm{L} \\
\text { annual average }\end{array}$ \\
\hline Columbia, SC & $2.9 \pm 0.2$ & $830 \pm 200$ \\
East Boundary & $5.4 \pm 0.5$ & $1500 \pm 250$ \\
West Boundary & $2.0 \pm 0.1$ & $1170 \pm 230$ \\
\hline
\end{tabular}

Table 6-7. 1992 direct radiation levels of South Carolina locations. ${ }^{6-3}$

\begin{tabular}{lll}
\hline $80-0001$ & Columbia, SC & $0.20 \mathrm{mRem} /$ day \\
$80-0940$ & Charleston, SC & $0.19 \mathrm{mRem} /$ day \\
$80-1451$ & Osborne Road $^{\mathrm{a}}$ & $0.23 \mathrm{mRem} /$ day \\
$80-0614$ & ${\text { Williston, } \mathrm{SC}^{\mathrm{a}}}^{\mathrm{a}}$ & $0.20 \mathrm{mRem} /$ day \\
$80-0660$ & Barnwell Airport & $0.21 \mathrm{mRem} /$ day \\
$80-0661$ & Williston, SC $^{\mathrm{a}}$ & $0.21 \mathrm{mRem} /$ day \\
\hline & & \\
\hline
\end{tabular}

\section{Soil}

Surficial soil samples are taken from the 10 boundary monitor stations at the site. The samples are analyzed for gamma-emitters using a germanium detector. Table 6-8 shows the concentrations of cesium-137, which is the only gamma-emitter detected in the samples. The concentrations are anticipated background levels.

In addition to surficial soil samples, bore hole samples are taken by Chem-Nuclear and analyzed for tritium and other radionuclides. Sediment samples taken from two surface water sources in the vicinity of the site are analyzed for gamma-emitters using a germanium detector. The concentrations of cesium-137, which is the only gamma-emitter detected, are shown in Table 6-9. The data indicate that the concentrations of radionuclides in the sediment are approximately that of background. 
Table 6-8. 1992 monitoring data for soil near the Barnwell site. ${ }^{6-3}$

(pCi/g \pm one standard deviation)

\begin{tabular}{ll}
\hline & Cesium-137 \\
\hline SS-0101 & $0.10 \pm 0.02$ \\
SS-0201 & $0.13 \pm 0.02$ \\
SS-0301 & $0.19 \pm 0.02$ \\
SS-0401 & $0.10 \pm 0.03$ \\
SS-0501 & $0.16 \pm 0.02$ \\
SS-0601 & $0.25 \pm 0.03$ \\
SS-0701 & $0.06 \pm 0.02$ \\
SS-0801 & $0.10 \pm 0.02$ \\
SS-0901 & $0.08 \pm 0.02$ \\
SS-1001 & $0.52 \pm 0.03$ \\
\hline
\end{tabular}

\section{Biota}

Vegetation samples are taken at the 10 boundary monitor stations at the site and are analyzed for gamma-emitters using a germanium detector. The concentration data in Table 6-10 indicate that cesium-137 in the vegetation samples are approximately that of background.

Table 6-9. 1992 monitoring data for sediment near the Barnwell site. ${ }^{6-3}$

\begin{tabular}{|c|c|}
\hline \multicolumn{2}{|c|}{ (pCi/g dry weight) } \\
\hline & Cesium-137 \\
\hline SD-0001 Duncannon Spring & $0.3 \pm 0.1$ \\
\hline SD-0002 Railroad Track Spring & $<0.01$ \\
\hline SD-0003 Grist Mill & $0.11 \pm 0.05$ \\
\hline SD-0004 Mary's Creek Spring & $0.05 \pm 0.02$ \\
\hline
\end{tabular}


Table 6-10. 1992 monitoring data for vegetation near the Barnwell site.

\begin{tabular}{cc}
\hline \multicolumn{2}{c}{ (pCi/g \pm one standard deviation) } \\
\hline VS-0101 & Cesium-137 \\
\hline VS-0201 & $<0.1$ \\
VS-0301 & $<0.1$ \\
VS-0401 & $<0.1$ \\
VS-0501 & $<0.1$ \\
VS-0601 & $<0.1$ \\
VS-0701 & $<0.1$ \\
VS-0801 & $<0.1$ \\
VS-0901 & $<0.1$ \\
VS-1001 & $0.10 \pm 0.05$ \\
\hline
\end{tabular}

\section{SUMMARY}

Two potential pathways to people exist on-site and off-site during the active life of the burial site at Barnwell. A low probability exists for (1) exposure from radioactive material released to the air and/or ground water and (2) exposure from direct gamma radiation. Release of radioactive material at the burial site is minimized since wastes are received and disposed in closed containers. The ground water and air are monitored on-site and off-site to detect any radioactive material which may be released.

Direct exposure from gamma radiation is highest in the immediate area of the open trenches. The trenches are posted radiation areas and the site access is restricted. The direct radiation levels at the site boundary are monitored continuously using TLDs. Results indicate that actual radiation dose to any member of the public is well below regulatory limits.

The exposure pathways which will exist after closure of the Barnwell site are release of material into the ground water and inadvertent intrusion into the waste. Subsidence of a trench could allow some release of radioactive material to the air, but this is unlikely since repairs will continue to be made during the institutional control period.

In 1978 during routine ground water monitoring, tritium was first detected in monitoring wells at the Barnwell site. This tritium has moved with the ground water away from the disposal area. Since 1987, CNSI has implemented a field program aimed at identifying the extent of tritium movement. Tritium was detected in CNSI monitoring wells further from the site than expected in June 1991. This tritium has entered Mary's Creek on Chem-Nuclear property. Currently, tritium concentrations within Mary's Creek are at background levels at the Chem-Nuclear/Savannah River Site property boundary. 
During 1991, CNSI installed an enhanced trench cap over 5 hectares (12.5 acres) of the old trench area. The cap consists of multi-layered synthetic and earthen materials as shown in Figure 6-4. The cap was designed to eliminate virtually all rainfall infiltration and thereby reduce further tritium migration from these early trenches.

During 1992, a year long drilling and geologic mapping project was performed by CNSI to identify the size and location of the plume. These new data show that most of the tritium south of the site is in a long narrow band within the plume. Also, most of the plume area has tritium concentrations less than EPA safe drinking water standard of $20,000 \mathrm{pCi} /$ liter. Figure 6-7 shows the approximate plume outline.$^{6-4}$ The geological maps developed during this study show that most of the tritium travels in a high transmissivity zone and eventually exits in a spring in Mary's Creek. The primary findings of the study are summarized below.

1. The tritium plume geometry and flow direction are affected by the nature of the Hawthorn/Barnwell formation contact as well as the potentiometric contours of the horizontal transport zone.

2. The tritium plume is approximately $230 \mathrm{~m}$ ( $750 \mathrm{ft})$ wide and $940 \mathrm{~m}(3,100 \mathrm{ft})$ long for an approximate surface area of about 20 hectares (50 acres). Three-fourths of the plume volume contains tritium concentrations less than $10,000 \mathrm{pCi} / \mathrm{L}$. About $1 \%$ of the plume volume is in an elongate narrow projection which has tritium concentrations in excess of 1 $\times 10^{6} \mathrm{pCi} / \mathrm{L}$.

The tritium plume is entirely on CNSI property except for two state-owned road right-of-ways. No private or public use is made of the ground water zone in which tritium is being transported. 


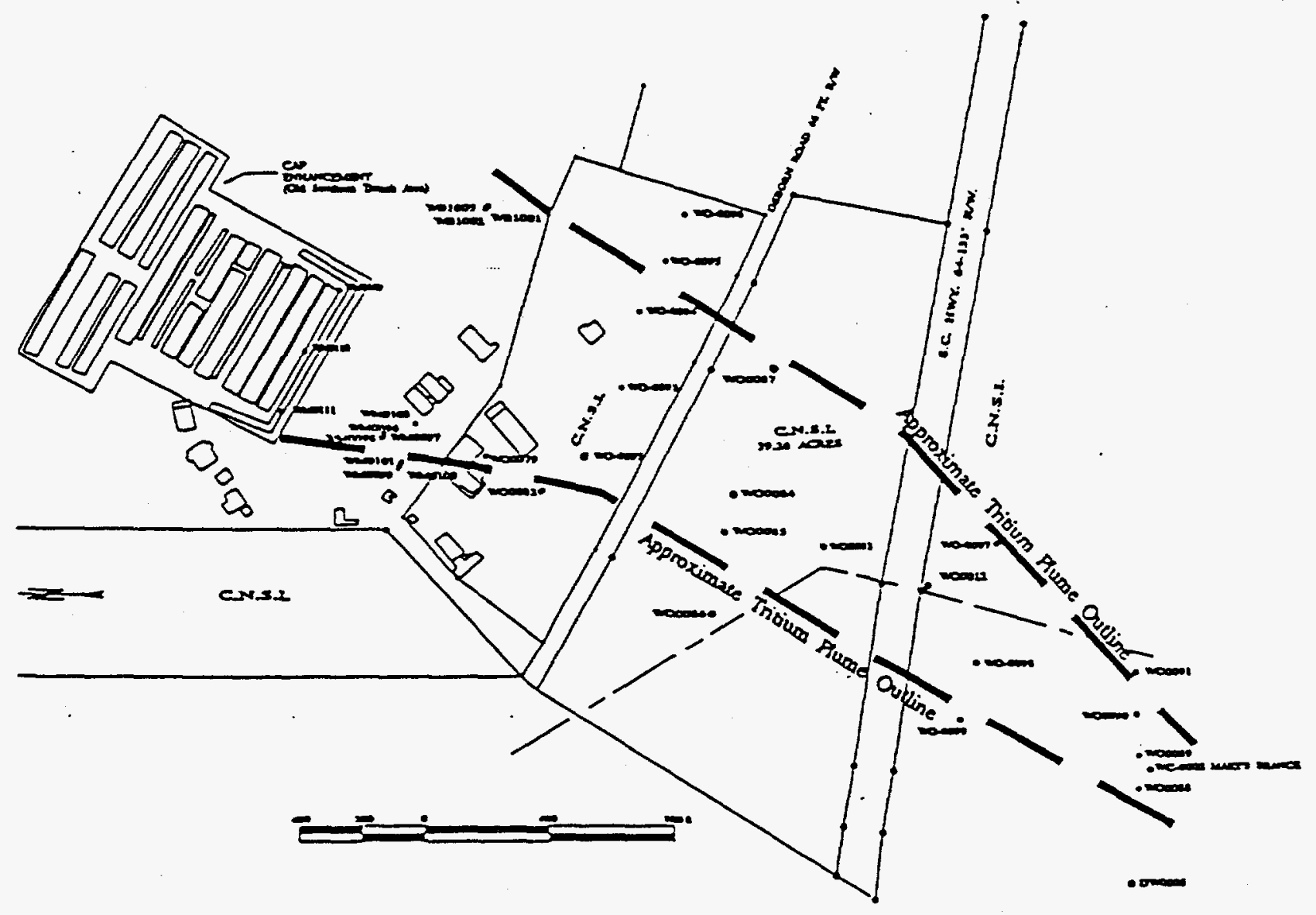

Figure 6-7. Approximate tritium plume outline south of the Barnwell site. 


\section{REFERENCES}

6-1. State Inspection Videotape, CRCPD, Inc., 1993.

6-2. Interim Site Stabilization and Closure Plan for the Barnwell Low-Level Radioactive Waste Disposal Facility, 1993 Closure Plan Revision, Chem-Nuclear Systems, Inc., September 1993.

6-3. South Carolina Department of Health and Environmental Control (DHEC), 1992 Summary Report Radiological Environmental Monitoring Around Chem-Nuclear Systems, Inc., Bureau of Radiological Health, June 1993.

6-4. Characterization Report Tritium Migration South of the Barnwell Site (BEDL-93-006), ChemNuclear Systems, Inc., Environmental and Dosimetry Laboratory, September 1993. 


\title{
CHAPTER 7
}

\section{Environmental Summary of the Richland, Washington Low-Level Radioactive Waste Disposal Site}

\author{
INTRODUCTION
}

\section{Background}

The Richland commercial low-level radioactive waste (LLW) burial site operated by US Ecology began operations in 1965. It is unique among comparable sites in that it is the only one located on federal land. The LLW facility occupies 0.4 square kilometers ( 100 acres) of land leased by US Ecology, Inc., on the Hanford Reservation that is in turn leased by the State of Washington from the U.S. Department of Energy (DOE).

\section{Location}

The burial site is located in north central Benton County, in the southeastern part of the state, about 37 $\mathrm{km}(23 \mathrm{mi})$ northwest of Richland, Washington (Figure 7-1). It is just southwest of the 200-East (200-E) Area and about $4.0 \mathrm{~km}(2.5 \mathrm{mi})$ east of the 200-West (200-W) Area, within the Separations Area of the Hanford Site (Figure 7-1). The Separations Area near the center of the Hanford site covers 212 square kilometers (82 square miles) and includes the 200-East and 200-West Areas, where several retired reactors, irradiated uranium fuels processing facilities, plutonium separation facilities, as well as major radioactive waste storage and disposal facilities are located and are still in active use.

\section{Facility}

The Richland site was originally operated by California Nuclear, Inc., and then by Nuclear Engineering Company, which is now known as US Ecology. The site received approximately 0.35 million cubic meters ( 12.3 million cubic feet) of low-level radioactive waste, with a total radioactivity of approximately $8.14 \mathrm{E}+16$ becquerels ( 2.2 million curies), as of December 31, 1992. The waste consists of solid or solidified materials, contaminated equipment, cleaning wastes, tools, protective clothing, gloves, and laboratory wastes. Unless specifically authorized by the Washington Department of Health, all radioactive waste is required to be received and buried in closed containers. Cardboard, corrugated paper, wood, and fiberboard (although in use during the early years) are prohibited burial containers. ${ }^{7-1}$

All waste and waste containers have been emplaced in trenches excavated into the surficial

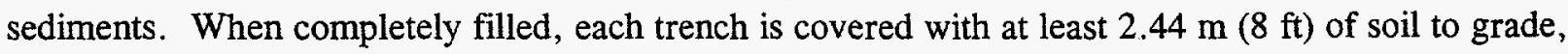
capped with a $15.24 \mathrm{~cm}$ ( $6 \mathrm{in}$.) layer of gravel, and then surcharged with spoils. Older trenches were covered with $0.915 \mathrm{~m} \mathrm{(} 3 \mathrm{ft}$ ) of soil prior to gravel placement. At present, the waste is contained in 


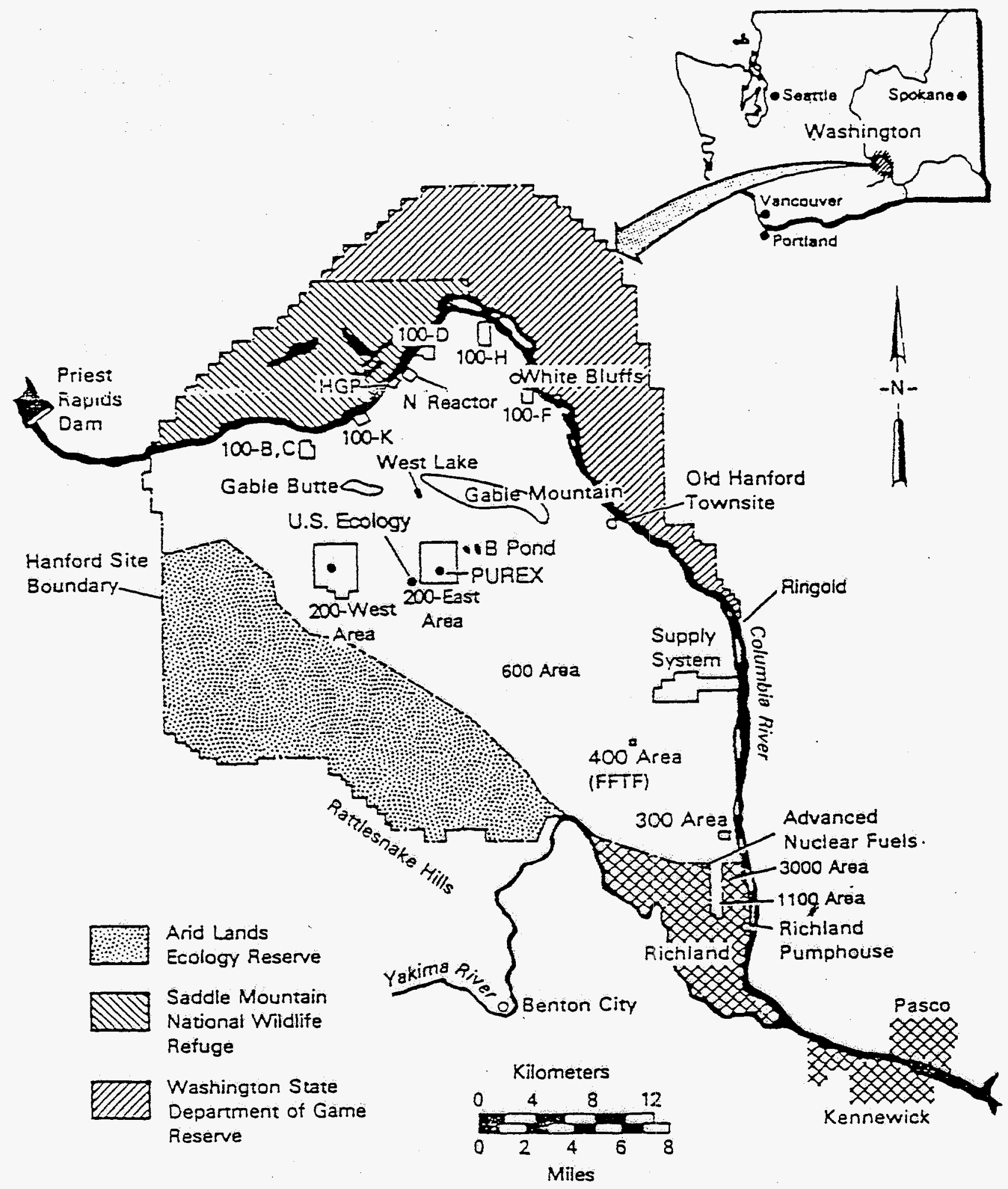

Figure 7-1. DOE Hanford site. 
19 separate trenches located on about 0.128 square kilometers ( 32 acres) in the southeast and eastcentral part of the facility (Figure 7-2). Trench size is variable, but the newer trenches are up to 45.75

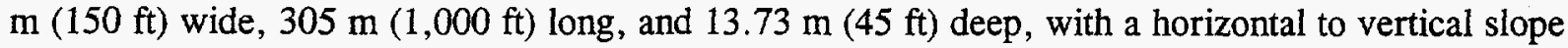
ratio of $1: 1$.

Radioactive wastes received at the Richland LLW facility are inspected by a permanent on-site Department of Health (DOH) inspector. The inspector reviews all shipping documents; surveys transport vehicles for radiation levels; visually inspects individual packages for appropriate markings, labels, and container integrity; and randomly inspects contents of containers. The inspector also verifies compliance with the radioactive materials license (WN-I019-2) issued by the State of Washington to US Ecology, Inc. ${ }^{7-1}$

A final Resource Conservation and Recovery Act (RCRA) Facility Assessment Report (FAR) was completed at the commercial LLW site by PRC Environmental Management, Inc. under contract from the U.S. Environmental Protection Agency (EPA). The FAR was performed to evaluate the facility's past and present solid waste practices. The US Ecology facility is not presently authorized to receive mixed or hazardous waste, but did dispose of material that is currently considered mixed waste such as scintillation fluids in Trenches 1 through $11 \mathrm{~A}$ prior to EPA's determination that such waste was subject to RCRA. The U.S. DOE Hanford site is seeking a RCRA permit to handle hazardous waste, and according to the EPA, the US Ecology facility, as part of the site, is therefore subject to investigation for corrective action.

The FAR concluded that Trenches 1 through 11A would require further investigation, which would include soil borings and additional ground water sampling. Soil borings would be analyzed to help determine whether constituents have migrated from the units. Ground water samples from the existing monitoring wells would be collected and analyzed for specific hazardous constituents (such as benzene and toluene) to determine if migration has occurred in those trenches.

\section{SITE}

\section{Topography}

The Hanford site occupies an area of about 1,450 square kilometers (560 square miles), north of the confluences of the Snake and Yakima rivers with the Columbia River (Figures 7-1, 7-3, and 7-4). Adjoining lands to the west, north, and east are principally flat or rolling range and agricultural land in Benton and Franklin Counties.

\section{Climate}

The Cascade Mountains to the west greatly influence the climate of the Hanford site. This range creates a rain shadow effect and also serves as a source of cold air drainage, which has a considerable effect on the wind regime. The prevailing wind direction on the 200 Area plateau, which includes the LLW site, is from the northwest in all months of the year. The secondary wind direction is from the southwest. Summaries of wind direction indicate that winds from the northwest quadrant occur most often during the winter and summer. During the spring and fall, the frequency of southwesterly winds increases with a corresponding decrease in the northwest flow. Monthly average wind speeds are 


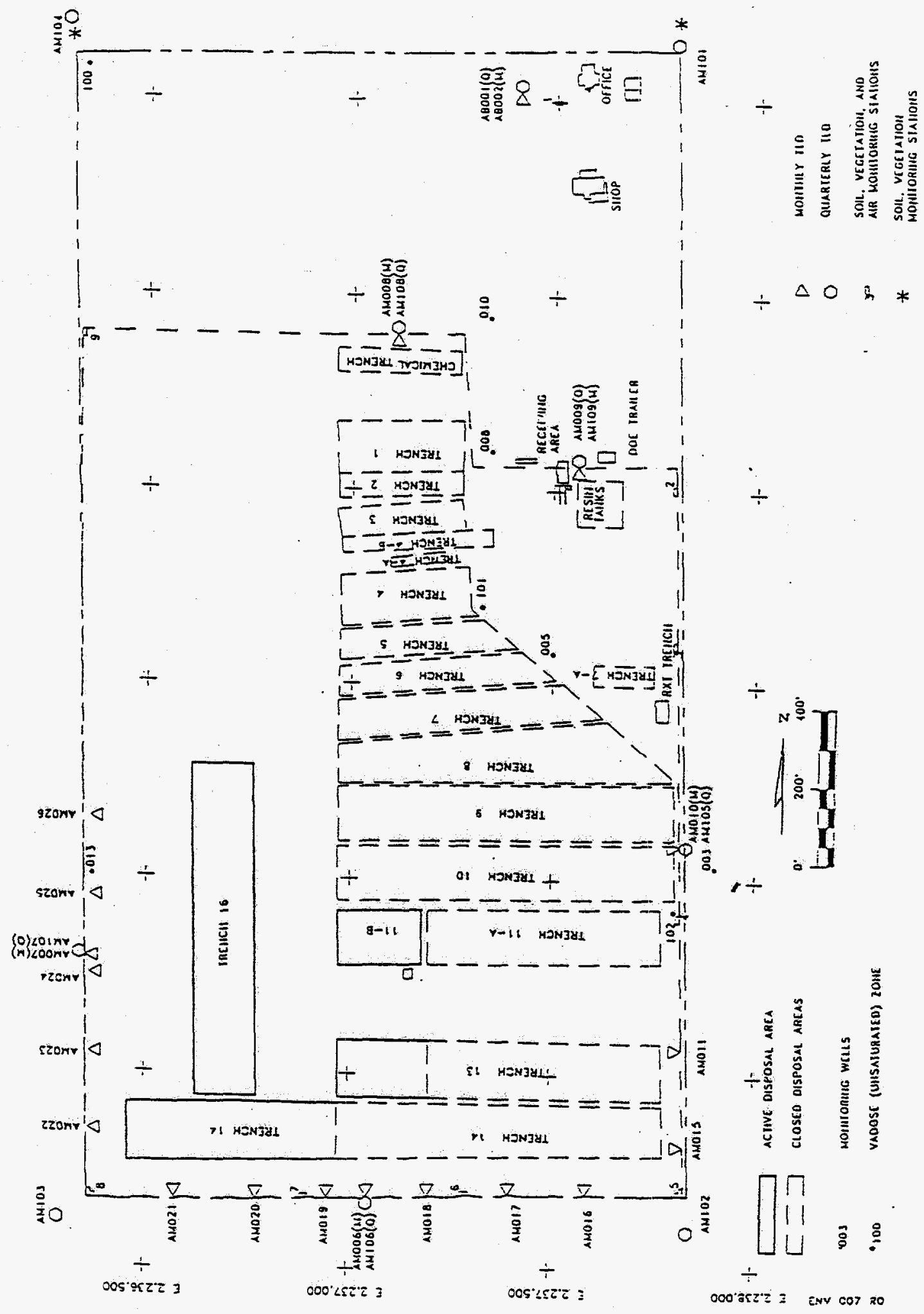

Figure 7-2. Low-level radioactive waste management facility, US Ecology, Inc., Richland, Washington. 


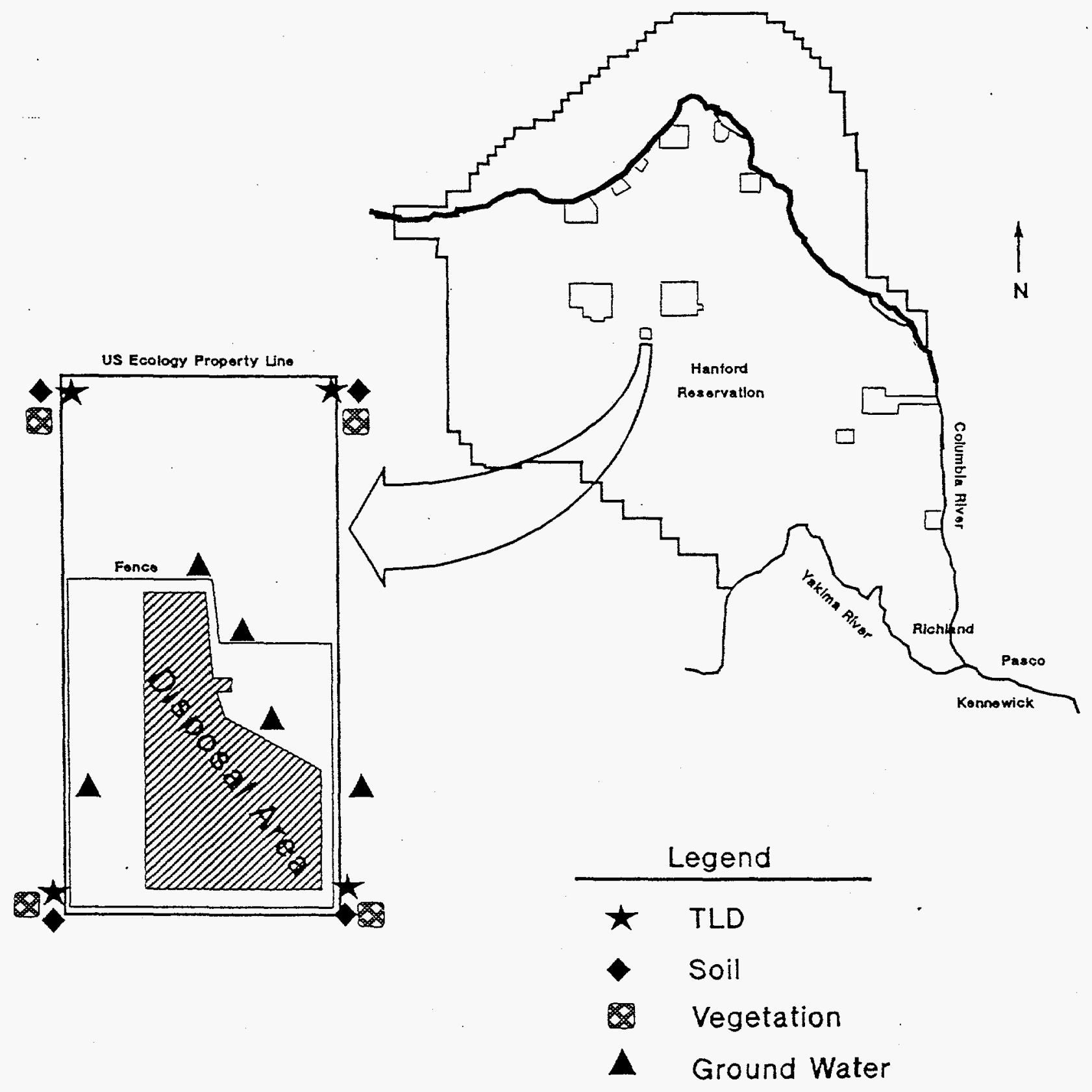

Figure 7-3. Environmental radiation sampling stations at the US Ecology site. 


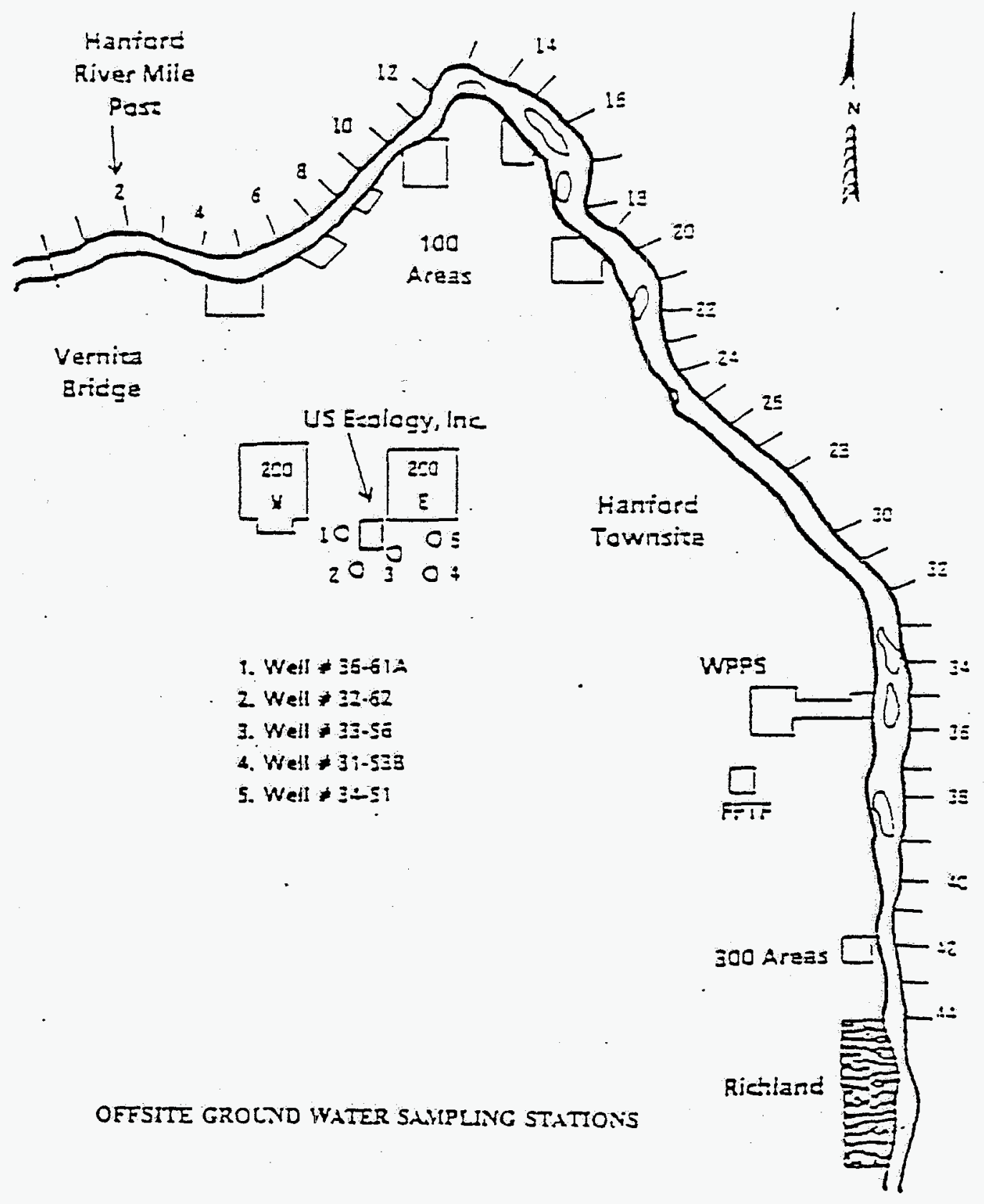

Figure 7-4. Environmental radiation sampling stations in the vicinity of the Hanford site.

lowest during the winter months, averaging 2.68 to $3.13 \mathrm{~m} / \mathrm{sec}$ ( 6 to 7 miles per hour), and highest during the summer, averaging 4 to $4.5 \mathrm{~m} / \mathrm{sec}$ ( 9 to 10 miles per hour). Wind speeds that are well above average are usually associated with southwesterly winds. However, the summertime drainage winds are generally northwesterly and frequently reach $13.4 \mathrm{~m} / \mathrm{sec}$ (30 miles per hour). These winds are most prevalent over the northern portion of the site.

The record maximum temperature is $46^{\circ} \mathrm{C}\left(115^{\circ} \mathrm{F}\right)$, and the record minimum temperature is $-32.8^{\circ} \mathrm{C}\left(-27^{\circ} \mathrm{F}\right)$. The average monthly temperatures have ranged from a low of $-1.5^{\circ} \mathrm{C}\left(29.3^{\circ} \mathrm{F}\right)$ in 
January to a high of $24.7^{\circ} \mathrm{C}\left(76^{\circ} \mathrm{F}\right)$ in July. During the winter, the highest monthly average temperature at the Hanford Meteorological Station (HMS) was $6.9^{\circ} \mathrm{C}\left(44.4^{\circ} \mathrm{F}\right)$, and the record lowest was $-5.9^{\circ} \mathrm{C}\left(21.4^{\circ} \mathrm{F}\right)$; both occurred during February. During the summer, the record maximum monthly average temperature was $27.9^{\circ} \mathrm{C}\left(82.2^{\circ} \mathrm{F}\right)$ in July, and the record lowest was $17.2^{\circ} \mathrm{C}\left(63^{\circ} \mathrm{F}\right)$ in June. The annual average relative humidity at the HMS is $54 \%$. It is highest during the winter months, averaging about $75 \%$, and lowest during the summer, averaging about $35 \%$. Average annual precipitation at the HMS is $16 \mathrm{~cm}$ (6.3 in.). Most of the precipitation occurs during the winter, with nearly half of the annual amount occurring in the months of November through February. Monthly climatological data from the HMS for 1991 is provided in Table $7-1 .^{7-2}$

Good dispersion conditions associated with neutral and unstable stratification exist about $57 \%$ of the time during the summer. Less favorable dispersion conditions (when the wind speed is light and the mixing layer is shallow) are most common during the winter, when moderately to extremely stable stratification exists about $66 \%$ of the time. Occasionally there are extended periods, primarily during winter months, of poor dispersion conditions that are associated with stagnant air in stationary highpressure systems.

\section{Land Use}

The Hanford site in southcentral Washington State is about 1,450 square kilometers ( 560 square miles) of semiarid shrub-steppe located just north of the confluence of the Snake and Yakima rivers. This land, with restricted public access, provides a buffer for the smaller areas historically used for the production of nuclear materials, waste storage, and waste disposal. About $6 \%$ of the land area has been disturbed and is actively used.

The Hanford site was acquired by the federal government in 1943. For more than 20 years, Hanford site facilities were dedicated primarily to the production of plutonium for national defense and management of the resulting wastes. In later years, programs at the Hanford site were diversified to include research and development for advanced reactors, renewable energy technologies, waste disposal technologies, and cleanup of contamination from past practices. The U.S. DOE has ended the production of defense-related nuclear materials at Hanford.

Non-DOE operations and activities include commercial power production (near the 400 Area), a commercial low-level radioactive waste burial facility (near the 200 Areas), a commercial nuclear fuel fabrication facility, and a low-level radioactive waste decontamination, supercompaction, and packaging disposal facility adjacent to the southern boundary of the Hanford site.

Land use in surrounding environs includes urban and industrial development, irrigated and dryland farming, and grazing. In 1989, wheat represented the largest single crop in terms of area planted in Benton and Franklin counties, with 864 square kilometers (216,000 acres). Corn, alfalfa, potatoes, asparagus, apples, cherries, and grapes are other major crops in Benton and Franklin counties. More than 20 processors in Benton and Franklin counties produce food products, including potato products, canned fruits and vegetables, wine, and animal feed. ${ }^{7-4}$ 


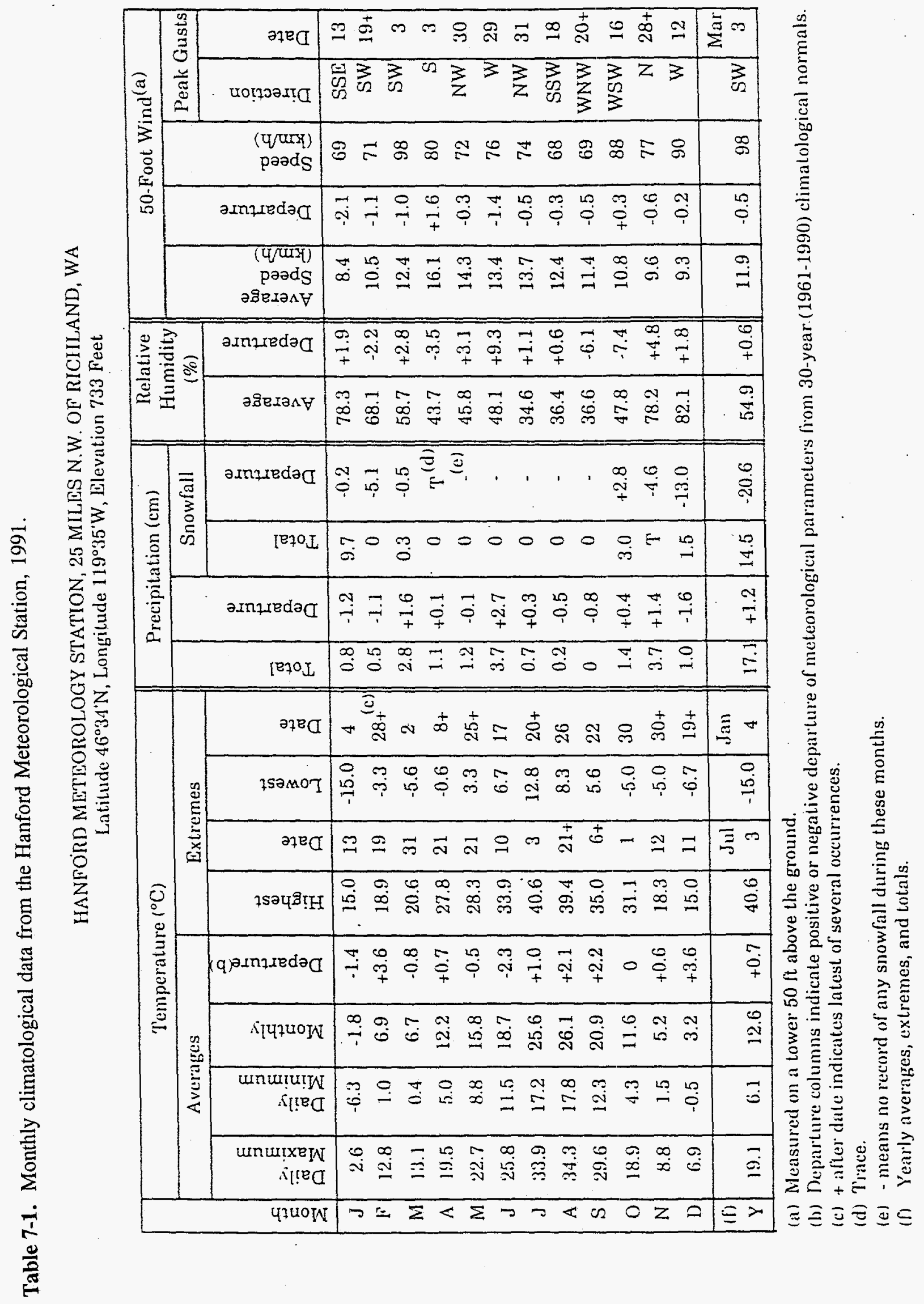


Estimates by the U.S. Census Bureau for 1990 place the population totals for Benton and Franklin counties at 112,560 and 37,473, respectively. The 1990 estimates for the Tri-Cities populations are Richland, 32,315; Kennewick, 42,159; and Pasco, 20,337. The populations of Benton City, Prosser, and West Richland totaled 10,244 in 1990. The population of Benton and Franklin counties is predominantly young, with $56 \%$ of the total population under the age of 35 , compared with $54 \%$ of the total state population. An examination of age groups in 5 year increments reveals that the largest age group in Benton and Franklin counties ranges from 5 to 9 years old, representing $9.3 \%$ of the total bicounty population; the largest group in the state ranges from 30 to 34 years, which represents about $9 \%$ of the total state population. ${ }^{7-4}$

\section{Geology}

The Hanford site lies within the Pasco Basin on the semi-arid alluvial plain of the Columbia River. The burial site is situated in glaciofluvial deposits from the ancestral Columbia River, which


in depth and overlay the Ringold Formation, which is a layer of sedimentary material ranging to $366 \mathrm{~m}$ $(1,200 \mathrm{ft})$ thick. Below this formation is bedrock consisting of the Yakima Basalt. ${ }^{7-4}$ Near the 200-West Area, the Ringold and Hanford Formations are separated by well-developed buried soil and fine-grained wind deposits. The stratigraphic and structural relationships between these units are displayed in Figure 7-5. ${ }^{7-4}$

\section{Surface Water}

The Columbia River is the dominant surface water body on the Hanford site and is approximately $12.9 \mathrm{~km}(8 \mathrm{mi})$ from the LLW site. The Columbia, which originates in the mountains of eastern British Columbia, Canada, drains a total area of approximately 70,680 square kilometers (27,300 square miles) en route to the Pacific Ocean. Flow of the Columbia River is regulated by 11 dams within the United States, 7 upstream and 4 downstream of the site. Priest Rapids is the nearest dam upstream of the site, and McNary is the nearest dam downstream. The Hanford Reach of the Columbia River extends from Priest Rapids Dam to the head of Lake Wallula (created by McNary Dam), near Richland. This Reach is the last stretch of the Columbia River in the United States above Bonneville Dam that remains unimpounded. The width of the river varies from approximately 300 to $1,000 \mathrm{~m}$ (984 ft to $3,281 \mathrm{ft}$ ) within the Hanford site.

The Columbia River flows eastward through the northern part of the Hanford site and then turns south, forming part of the eastern boundary. The Yakima River runs along part of the southern boundary and joins the Columbia River below the city of Richland. The Columbia River flows through the reservation about $27.4 \mathrm{~km}(17 \mathrm{mi})$ from the waste disposal site.

No surface water bodies are on or near the Hanford site. A number of man-made ponds have been created by U.S. DOE for the disposal of reactor cooling water and liquid wastes.

Typical flow rates of the Columbia River range from 999 to 6,995 cubic $\mathrm{m} / \mathrm{sec}(35,310$ to $247,170 \mathrm{cubic} \mathrm{ft} / \mathrm{sec})$, with peak spring runoff flows of up to $12,590 \mathrm{cubic} \mathrm{m} / \mathrm{sec}(444,906 \mathrm{cubic}$ $\mathrm{ft} / \mathrm{sec})$. The minimum regulated flow is $1,019 \mathrm{cubic} \mathrm{m} / \mathrm{sec}(36,016 \mathrm{cubic} \mathrm{ft} / \mathrm{sec})$. 


\section{GEOLOGIC CROSS-SECTION OF THE SITE}

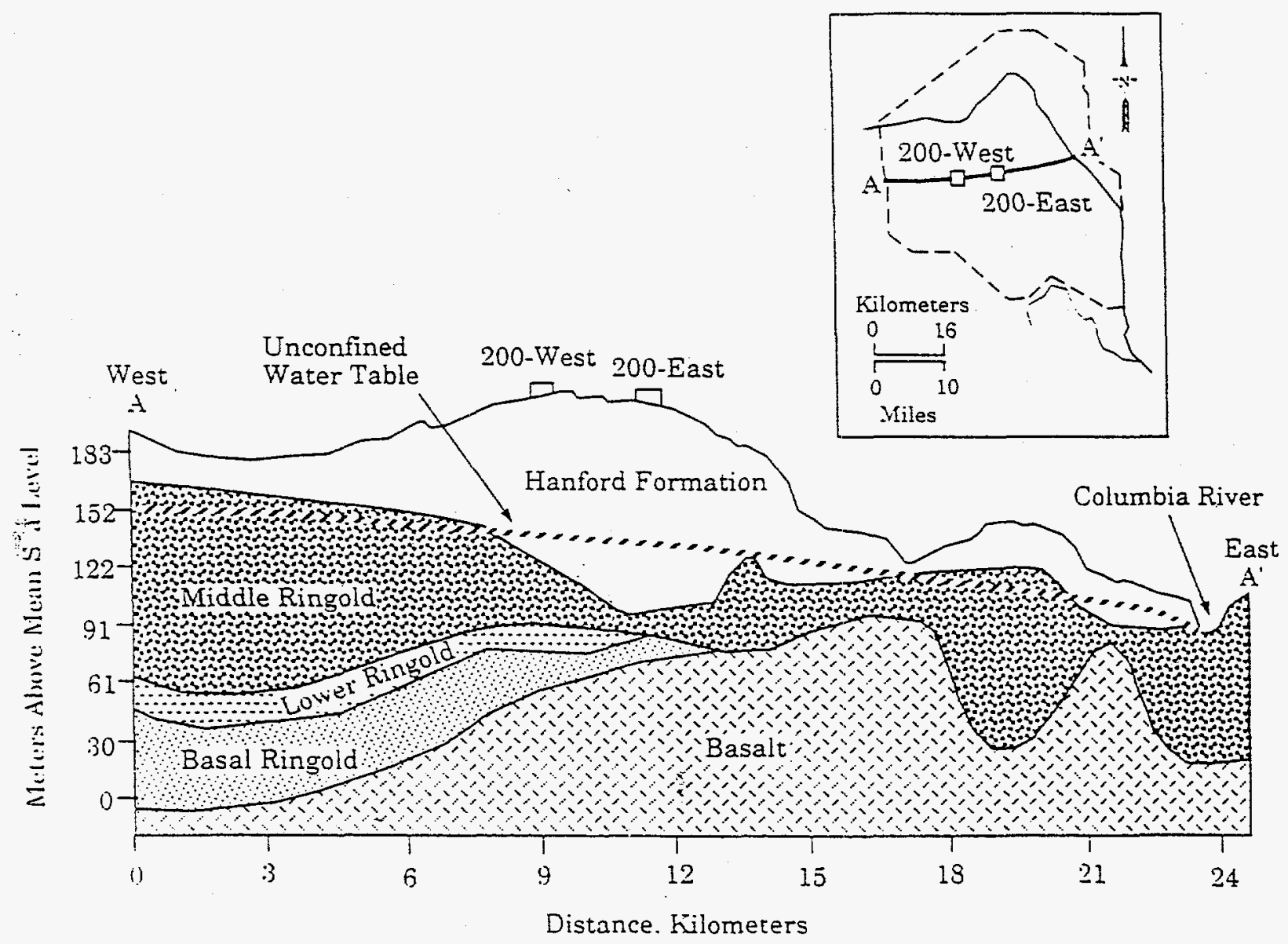

Figure 7-5. Geological cross-section of the Hanford site.

The temperature of the Columbia River varies seasonally. Minimum temperatures are observed during January and February, and maximum temperatures typically occur during August and September. Mean monthly temperatures for the river range from approximately $3^{\circ} \mathrm{C}\left(37^{\circ} \mathrm{F}\right)$ to about $20^{\circ} \mathrm{C}\left(68^{\circ} \mathrm{F}\right)$. 


\section{Ground Water}

Both confined and unconfined aquifers are present beneath the Hanford site. The confined aquifers, where ground water is under pressure greater than that of the atmosphere, are found primarily within the Columbia River basalts. In general, the unconfined or water table aquifer is located in the Ringold Formation and glaciofluvial sediments, as well as some more recent alluvial sediments in areas adjacent to the Columbia River. This relatively shallow aquifer has been affected by wastewater disposal by U.S. DOE. Therefore, the unconfined aquifer is the most thoroughly monitored aquifer beneath the Hanford Reservation.

The unconfined aquifer is bounded below by either the basalt surface or, in places, the relatively impervious clays and silts of the Ringold Formation. The water table defines the upper boundary of the unconfined aquifer. Laterally, the unconfined aquifer is bounded by the basalt ridges that surround the basin and by the Yakima and Columbia Rivers. The basalt ridges have a low permeability and act as a barrier to lateral flow of ground water where they rise above the water table. Depth from the ground surface to the water table ranges from less than $0.30 \mathrm{~m}(1 \mathrm{ft})$ at the Columbia River to more than $106 \mathrm{~m}$ ( $348 \mathrm{ft}$ ) in the center of the Hanford site. The depth to ground water at the US Ecology LLW site is about $97 \mathrm{~m}(317 \mathrm{ft})$.

The operational discharge of water by U.S. DOE facilities has created ground water mounds near each of U.S. DOE's major waste water disposal facilities in the 200 Areas. These mounds have altered the aquifer's local flow pattern, which is generally from the recharge areas in the west to the discharge areas (primarily the Columbia River) in the east. Water levels in the unconfined aquifer have changed continually during site operations because of variations in the volume of waste water discharged. Consequently, the movement of ground water and its associated constituents has also changed with time. $^{7-4}$

Ground water mounding also occurs in the 100 and 300 Areas. Ground water mounding in these areas is not as significant as in the 200 Areas because of differences in discharge volumes and subsurface geology. In the 100 and 300 Areas, water levels are also greatly influenced by river stage.

\section{Ecology}

The Hanford site is a relatively large, undisturbed area of shrub-steppe that contains numerous plant and animal species adapted to the region's semiarid environment. Table 7-2 lists some of the mammals, birds, and vegetation found in the area.

More than 240 species of plants have been identified on the entire Hanford site, and cheatgrass is the dominant plant on fields that were cultivated 40 years ago. ${ }^{7-4}$

More than 300 species of terrestrial and aquatic insects, 12 species of reptiles and amphibians, 44 species of fish, 187 species of birds, and about 39 species of mammals have been found on the Hanford site. Deer and elk are the major large mammals on the site; coyotes are plentiful, and the Great Basin pocket mouse is the most abundant mammal. Waterfowl are numerous on the Columbia River; the bald eagle is a regular winter visitor along the river. Salmon and steelhead are the fish species of most interest. 
Table 7-2. Common species of mammals, birds, and vegetation.

\begin{tabular}{|c|c|}
\hline Mammals and birds & Vegetation \\
\hline Mule deer (Odocoileus hemionus) & $\begin{array}{l}\text { Bluebunch wheatgrass (Agropyron } \\
\text { spicatum) }\end{array}$ \\
\hline \multicolumn{2}{|l|}{ Coyote (Canis latrans) } \\
\hline & Cheatgrass (Bromus tectroum) \\
\hline \multicolumn{2}{|l|}{ Badger (Taxidea taxus) } \\
\hline & Bitterbrush (Purshia tridentata) \\
\hline \multicolumn{2}{|l|}{ Black-tailed hare (Lepus californicus) } \\
\hline $\begin{array}{l}\text { Great basin pocket mouse (Perognathus } \\
\text { parvus) }\end{array}$ & $\begin{array}{l}\text { Greasewood/saltgrass (Sarcobatus } \\
\text { vermiculatus) }\end{array}$ \\
\hline parvus) & Winterfat (Eurotia lanata) \\
\hline \multicolumn{2}{|l|}{ Deer mouse (Peromyscus maniculatus) } \\
\hline \multirow{6}{*}{ Western meadowlark (Sturnella neglecta) } & Thyme buckwheat (Eriogonum thymoides) \\
\hline & \\
\hline & Tumble mustard (Sisymbrium altissimum) \\
\hline & Willow (Salicaceae) \\
\hline & Sandberg's bluegrass (Poa sandbergii) \\
\hline & Sagebrush (Artemisia tridentata) \\
\hline
\end{tabular}

No federally designated threatened or endangered animal species are known to inhabit the facility or the leasehold. However, the bald eagle (Haliaeetus leucocephalus), a threatened species, and the peregrine falcon (Falco peregrinus), an endangered species, have been seen on the Reservation and may pass over the facility.

\section{ENVIRONMENTAL MONITORING}

\section{Overview}

Environmental monitoring is performed at the Richland LLW facility to demonstrate compliance with federal, state, and local regulations; confirm adherence to environmental protection policies; and support the environmental management decisions. These regulations require that effluents to the general environment be maintained as low as reasonably achievable (ALARA) and that annual doses due to effluents not exceed 0.25 millisievert ( 25 millirems) to the whole body, 0.75 millisievert ( 75 millirems) to the thyroid, and 0.25 millisievert ( 25 millirems) to any other organ of any member of the public.

The Department, with assistance from many other agencies, operates a statewide environmental radiation monitoring program. It also audits surveillance programs required of licensees and other 
nuclear facilities. The state's independent program also serves to verify the adequacy and accuracy of a facility's program.

The major goals of the environmental radiation program are to identify, assess, and initiate appropriate corrective actions needed to prevent any potential exposure to the public, or contamination of the environment before a significant problem develops.

The environmental monitoring program at the Richland LLW facility monitors all pathways through which individuals living outside the Hanford site could be exposed to radiation or radioactive materials released from the site. These include direct radiation, atmospheric exposure, and from radionuclide releases into the ground water.

Environmental monitoring programs are conducted by the State of Washington and US Ecology, Inc. at the LLW facility. The monitoring of potential environmental pathways of exposure include nine fixed environmental air stations, routine monitoring of both soil and live vegetation (when available), environmental thermoluminescent dosimeters, five ground water wells (Figures 7-2 and 7-3), and vadose zone monitoring. The specific requirements for environmental monitoring are defined in the Facility Standards Manual ${ }^{7-3}$ and are described in detail in the US Ecology Annual Environmental Reports. ${ }^{7-4}$

Environmental monitoring began in the first quarter of 1966 . Soil and vegetation samples were taken from the vicinity of the four facility corners by the facility operators (US Ecology, Inc., formerly California Nuclear, Inc., then NECo). Starting in the first quarter of 1964, the U.S. AEC provided the licensee with the results of the analysis of ground water samples taken from wells near the 200-W and 200-E areas (Figure 7-6) which were closest to the facility. Until the first quarter of 1973, only gross beta concentrations were monitored in ground water. Beginning in 1977, Battelle gathered the ground water samples, U.S. Testing analyzed the samples and provided the analytical results to the State of Washington, and Battelle then distributed the data to the facility operator (US Ecology). In 1986, US Ecology began performing ground water sampling in the newly constructed on-site ground water wells, with U.S. Testing performing the analysis.

Environmental sampling for air and particulate airborne radioactivity was initiated in January 1987. Prior to that time (beginning in December 1978), downwind operational low-volume air sampling was performed at a location near the east fence. As new trenches became operational, this location was moved to the south fence.

Ambient gamma measurements were performed, using thermoluminescent dosimeters (TLDs) posted at the facility corners, which were then collected quarterly. Monthly TLDs were posted at the north, south, east, and west fencelines and at a downwind location.

Monitoring of the milk pathway at the Hanford site is not possible because no farms or cattle are near the site. However, milk is collected every other week throughout the year from farms east of the Hanford Reservation (approximately $32 \mathrm{~km}(20 \mathrm{mi})$, in the prevailing downwind direction) and analyzed for radionuclides. Wildlife is collected at the Reservation and is analyzed annually. Analysis of vegetation samples serves to provide an indication of any radionuclides which could be included in the diet of wildlife. 


\section{ENVIRONMENTAL RADIATION SAMPLING STATIONS \\ IN THE YICINITY OF HANFORD}

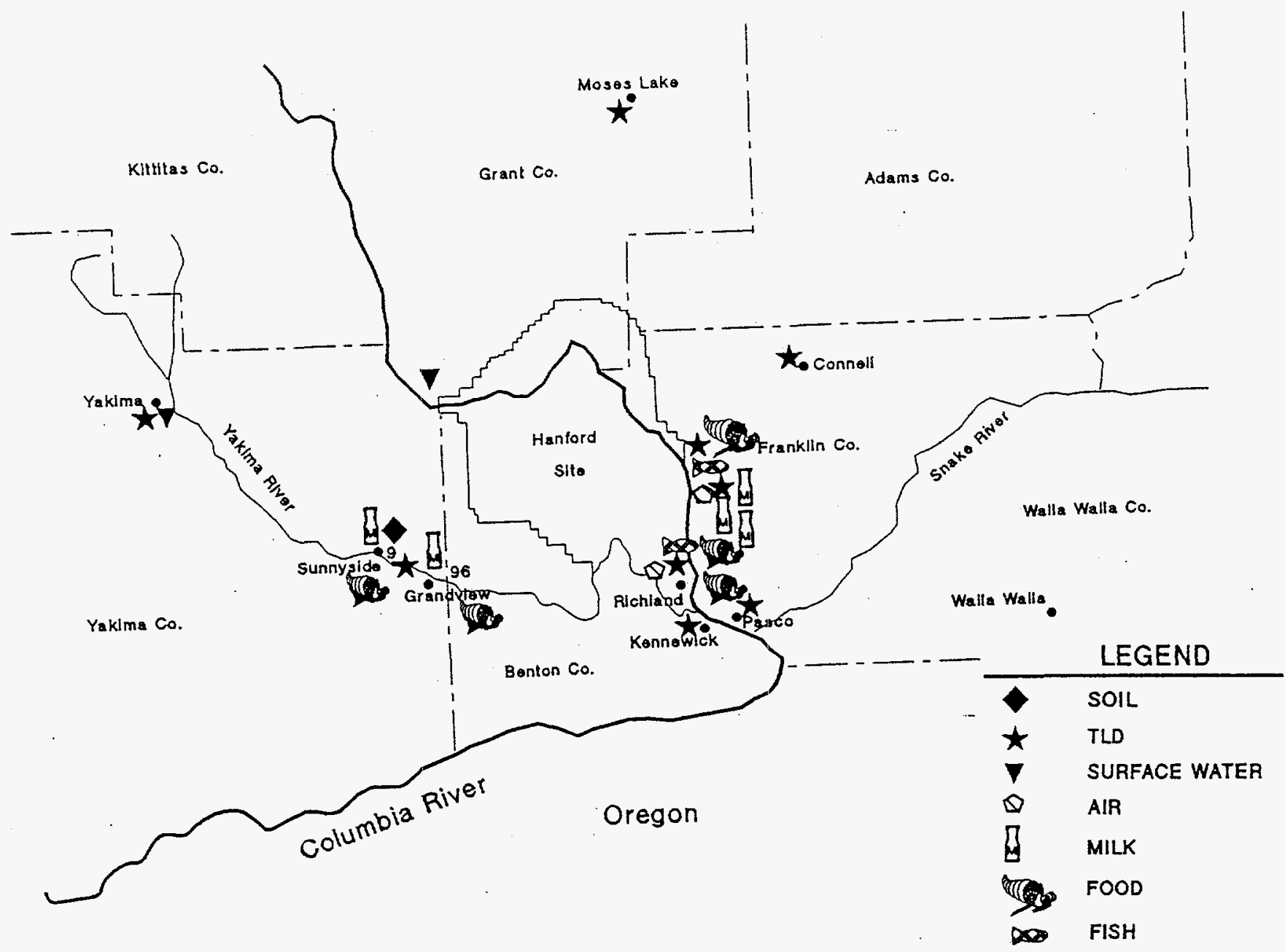

Figure 7-6. Off-site ground water sampling stations near the Hanford site.

Table 7-3 describes the environmental monitoring program and action levels as required by the Washington State Department of Health. Actions required whenever environmental action levels are exceeded are given in Table 7-4. Table 7-5 summarizes the requirements for minimum detectable concentrations for gamma spectroscopy of environmental samples. Figures 7-2, 7-3, 7-4, and 7-6 show the locations of all environmental monitoring stations on the facility; these are described in Table 7-3. 
Table 7-3. Environmental/occupational monitoring requirements.

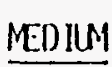

\section{LOCATION}

$N, N E, S W$,

SE Comers and

$N, S, E, W$

Fenolines

$N, S, E, W$

Fenoel Ines

and

Fencel Ine

position(s)

mearest eadi active

disposal trendi

$\begin{array}{ll}\text { TYPE, FPEQUENCY } & \text { NWALYSIS } \\ \begin{array}{l}\text { Continuous, } \\ \text { Quarterly }\end{array} & \begin{array}{l}\text { Tissue dose } \\ \text { using themo- } \\ \text { luminescent } \\ \text { dosineters }\end{array} \\ \begin{array}{l}\text { Continuous, } \\ \text { Monthly }\end{array} & \begin{array}{l}\text { Tissue dose } \\ \text { using themo- } \\ \text { luninescent } \\ \text { dosimeters }\end{array}\end{array}$

ACTION LEVEIS

\begin{tabular}{|c|c|c|}
\hline \multicolumn{2}{|c|}{ ACTION LEVEIS } & \multirow[b]{2}{*}{$\begin{array}{l}\text { ACTION } \\
\text { CATEGORY }\end{array}$} \\
\hline $\begin{array}{l}\text { INESTIGATION } \\
\text { LEVE. }\end{array}$ & $\begin{array}{l}\text { PEPORTING } \\
\text { LEVEI. }\end{array}$ & \\
\hline 120 mentatr & $500 \mathrm{mmem} /$ year & 3,4 \\
\hline
\end{tabular}

40 mmem/nonth

500 mran/year

3,1

NOIES 1) Table 6.4 presents the action required based upon action categorles.

2) If $\mathrm{Ac}-227$ is listed on mantfest or knom to be present, the reporting level is $3.0 \times 10^{-13} \mathrm{uCl} / \mathrm{cc}$.

3) The required minfum detection concentrations $\left(M C^{\prime}\right.$ 's) are listed in Table 4.3 .

4) $M=$ Not appl Icable or none establ Ished.

5) Dry to wet ratio will be obtained

6) Total uraniun analysis is defined as the sun of the concentrations of uranium isotopes reported.

7) These are interim neporting leveis

8) Concentrations will be evaluated and reported annually in the enviromental report.

9) Field blark analys is is the sane as well sample analysis.

10) Used for sanple Qh. 
Table 7-3. (continued).

\begin{tabular}{|c|c|c|c|c|c|c|}
\hline \multirow[b]{2}{*}{ MDILM } & \multirow[b]{2}{*}{ LOCATION } & \multirow[b]{2}{*}{ TYPE, FREQLENCY } & \multirow[b]{2}{*}{ AWLYSIS } & \multicolumn{2}{|c|}{ ACTION LEVES } & \multirow[b]{2}{*}{$\begin{array}{c}\text { ACTION } \\
\text { CATEGORYI } \\
\end{array}$} \\
\hline & & & & $\begin{array}{l}\text { INVESTIGATION } \\
\text { LEVEI } \\
\end{array}$ & $\begin{array}{l}\text { REPORTING } \\
\text { LEVEL } \\
\end{array}$ & \\
\hline $\mathrm{Soil}^{5}$ & $\begin{array}{l}\text { Env. Monitoring } \\
\text { Stations } 1-9 \text { and } \\
\text { NE. MH Comers }\end{array}$ & Grab, Quarterly & $\begin{array}{l}\text { Gross Beta } \\
\text { Total Uraniun } 6 \\
\text { Pu-238 } \\
\text { Pu-239/240 } \\
\text { Co-60 } \\
\text { Cs-137 } \\
\text { Gamia Spec }\end{array}$ & $\begin{array}{l}36 \mathrm{pCi} / \mathrm{g} \text { (dry) } \\
1 \mathrm{pCi} / \mathrm{g} \text { (dry) } \\
0.03 \mathrm{pC1} / \mathrm{g} \text { (dry) } \\
0.03 \mathrm{pC} / \mathrm{g} \text { (dry) } \\
0.3 \mathrm{pCi} / \mathrm{g} \text { (dry) } \\
0.25 \mathrm{pC1/g} \text { (dry) } \\
5 \times \mathrm{MDC}^{3}\end{array}$ & 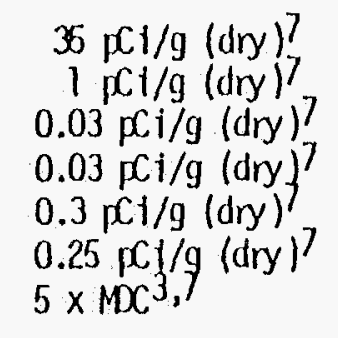 & $\begin{array}{l}3,4 \\
3,4 \\
3,4 \\
3,4 \\
3,4 \\
3,4 \\
3,4\end{array}$ \\
\hline \multirow[t]{2}{*}{ Vegtation 5} & $\begin{array}{l}\text { Env. Mont toring } \\
\text { Stations } 1-9 \text { and } \\
N E, N W \\
\text { Cormers }\end{array}$ & $\begin{array}{l}\text { Grab, Quarterly } \\
\text { for deep nooted }\end{array}$ & $\begin{array}{l}\text { Gross Beta } \\
\text { Total Uraniuni } \\
\text { Pu-230 } \\
\text { Pu-239/240 } \\
\text { Co-60 } \\
\text { Cs-137 } \\
\text { Gamma Spec }\end{array}$ & $\begin{array}{c}100 \mathrm{pCl} / \mathrm{g} \text { (dry) } \\
0.25 \mathrm{pC} / \mathrm{g}(\mathrm{dry}) \\
0.02 \mathrm{pCl} / \mathrm{g} \text { (dry) } \\
0.02 \mathrm{pCl} / \mathrm{g}(\mathrm{dry}) \\
0.1 \mathrm{pC1} / \mathrm{g}(\mathrm{dry}) \\
0.2 \mathrm{pCl} / \mathrm{g}(\mathrm{dry}) \\
5 \times \mathrm{MC}^{3}\end{array}$ & 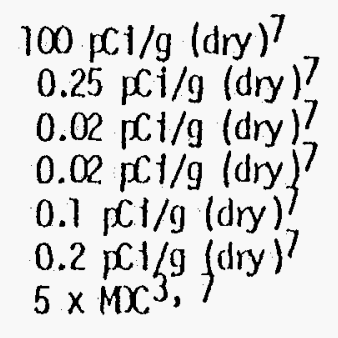 & $\begin{array}{l}3,4 \\
3,4 \\
3,4 \\
3,4 \\
3,4 \\
3,4 \\
3,4\end{array}$ \\
\hline & $\begin{array}{l}\text { Filled and capped } \\
\text { trendes }\end{array}$ & Grab, Ânnuaīy & $\begin{array}{l}\text { Gross Deta } \\
\text { Total Uraniumi } \\
\text { Pu-230 } \\
\text { Pu-239/240 } \\
\text { Co-60 } \\
\text { Cs-137 } \\
\text { Gamma Spec } \\
\text { H-3 }\end{array}$ & $\begin{array}{l}100 \mathrm{pCi} / \mathrm{g} \text { (dry) } \\
0.25 \mathrm{pCi} / \mathrm{g} \text { (dry) } \\
0.02 \mathrm{pCi} / \mathrm{g} \text { (dry) } \\
0.02 \mathrm{pCi} / \mathrm{g} \text { (dry) } \\
0.1 \mathrm{pCi} / \mathrm{g} \text { (dry) } \\
0.2 \mathrm{pCi} / \mathrm{g} \text { (dry) } \\
5 \times \mathrm{MCC}^{3} \\
\mathrm{~N}^{4}, 8\end{array}$ & 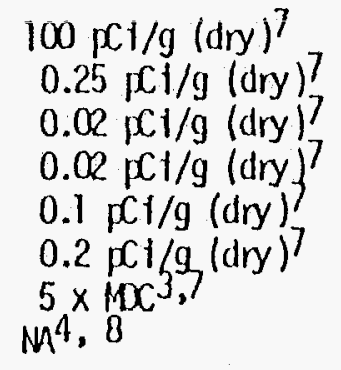 & $\begin{array}{l}3,4 \\
3,4 \\
3,4 \\
3,4 \\
3,4 \\
3,4 \\
3,4\end{array}$ \\
\hline
\end{tabular}


它淁|

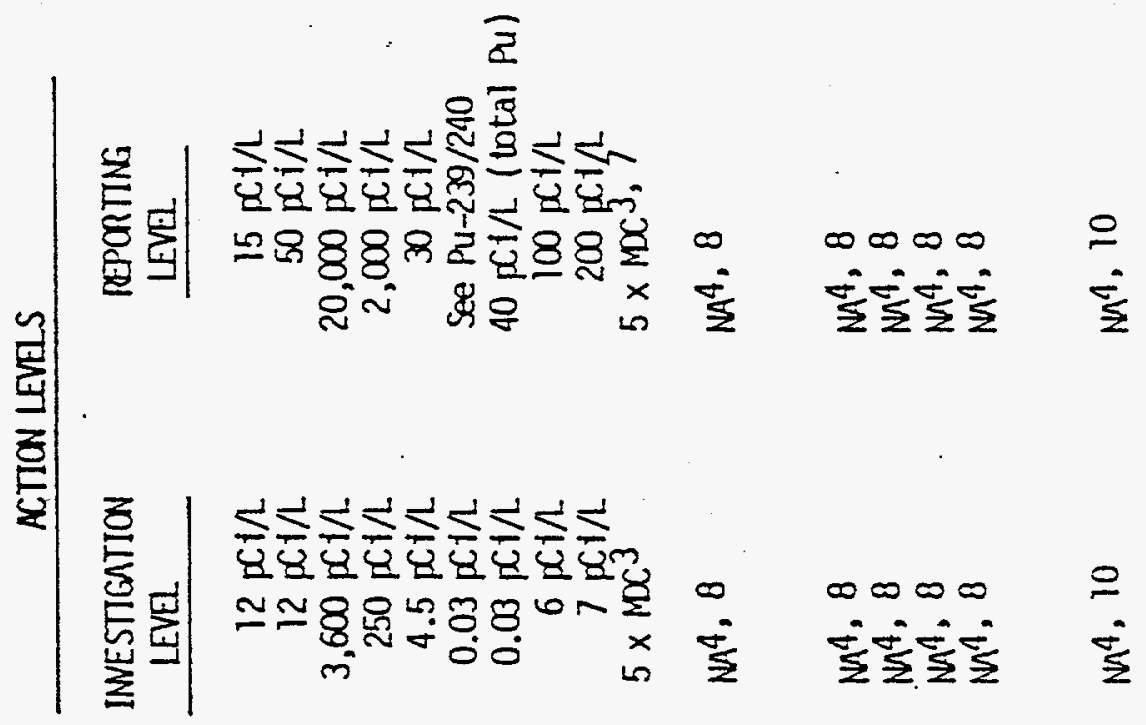

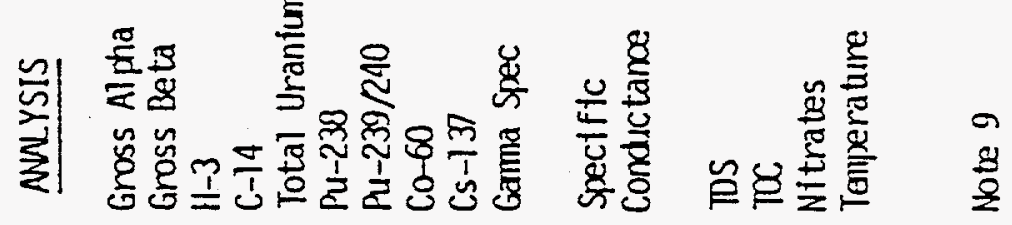

竞| $\frac{7}{\frac{1}{9}}$

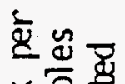

즐임

동

으용

ह)

뜽옹요요용

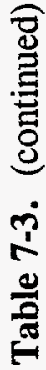

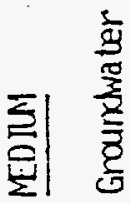

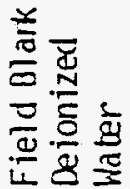


Table 7-3. (continued).

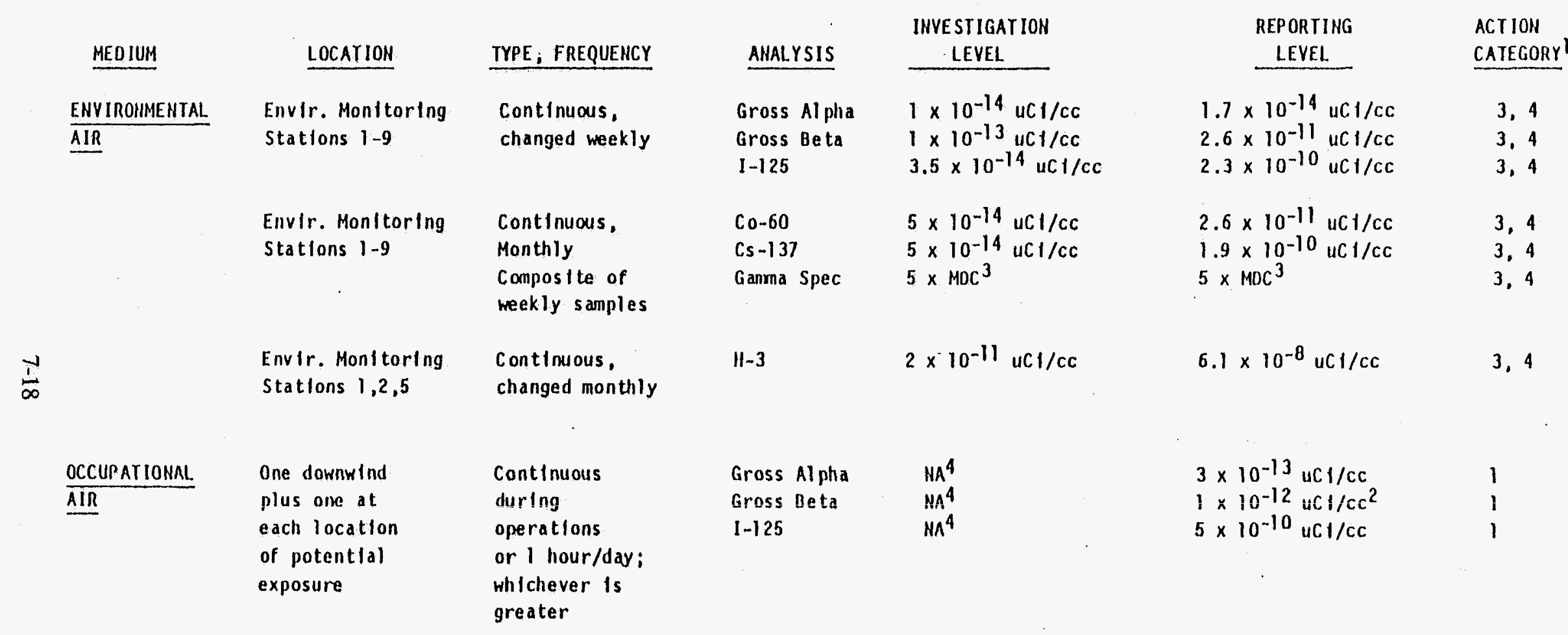


Table 7-4. Action required when action level met or exceeded.

1. Type 1 Event

Follow reporting level requirements

Potential for bioassay examined by facility and corporate radiation office

2. Type 2 Event

Immediate notification of on-site inspector

Take corrective action

3. Investigation Level

Notify the facility and corporate radiation office

Take corrective actions described in facility safety manual 6.1.5

4. Reporting Level

Notify the facility and corporate radiation office, the Department, the US NRC within 24 hours upon confirmation

Take corrective actions described in facility safety manual 6.1.5

Make reports in accordance with facility safety manual 6.1.4.C

5. Resurvey with dose rate instrument for fixed contamination/radiation level and smears for loose contamination. If does rate $<0.1 \mathrm{mR} / \mathrm{hr}$ and loose contamination $<220 \mathrm{dpm} / 100 \mathrm{~cm}^{2}$, no further action is required. If does rate is $\geq 0.1 \mathrm{mr} / \mathrm{hr}$ or loose contamination is $\geq 220$ $\mathrm{dpm} / 100 \mathrm{~cm}^{2}$, then take actions per $\# 2$ above.

Radon gas monitoring was initiated in 1993 at selected air monitoring stations. This program utilizes track etch detectors to provide data on airborne radon concentrations. Table 7-6 provides the results of this study.

\section{Ground Water}

Ground water samples are analyzed for radiological as well as non-radiological constituents. Radiological analyses include gross alpha, gross beta, tritium, C-14, gamma-emitters, isotopic plutonium ( $\mathrm{Pu}-238$ and Pu-239/240), and isotopic uranium (U-234, U-235, and U-238).

Non-radiological parameters include temperature, specific conductivity, total organic carbon (TOC), nitrates, and total dissolved solids (TDS).

Starting in the first quarter of 1964 , the U.S. AEC provided the Richland LLW facility operator with the results of analysis of ground water samples taken from the wells in the vicinity of the LLW disposal site (Figure 7-6). Until the first quarter of 1973, only gross beta concentration was monitored in ground water. Starting in 1974, the samples were analyzed for gross alpha, gross beta, tritium, and by gamma spectroscopy. Samples of US Ecology's on-site wells (Figures 7-2 and 7-3) began during the first quarter of 1986. 
Table 7-5. Required minimum detectable concentrations (MDCs) for gamma spectroscopy analysis of environmental samples.

\begin{tabular}{|c|c|c|c|c|}
\hline Radionuclide & $\begin{array}{l}\text { Water } \\
(\mathrm{pCi} / \mathrm{L}) \\
\end{array}$ & $\begin{array}{l}\text { Airborne Activity } \\
\left(\mathrm{pCi} / \mathrm{m}^{3}\right)\end{array}$ & $\begin{array}{c}\text { Soil } \\
\text { (pCi/g-dry) }\end{array}$ & $\begin{array}{c}\text { Vegetation (pCi/g- } \\
\text { dry) }\end{array}$ \\
\hline $76 \mathrm{As}$ & 16 & 0.02 & 0.03 & 0.05 \\
\hline 140BaLa & 24 & 0.02 & 0.05 & 0.07 \\
\hline $141 \mathrm{Ce}$ & 10 & 0.01 & 0.02 & 0.03 \\
\hline $144 \mathrm{CePr}$ & 92 & 0.09 & 0.18 & 0.10 \\
\hline $58 \mathrm{Co}$ & 10 & 0.01 & 0.02 & 0.03 \\
\hline $60 \mathrm{Co}$ & 11 & 0.01 & 0.02 & 0.03 \\
\hline $134 \mathrm{Cs}$ & 11 & 0.01 & 0.02 & 0.03 \\
\hline $137 \mathrm{Cs}$ & 10 & 0.01 & 0.02 & 0.03 \\
\hline $152 \mathrm{Eu}$ & 56 & 0.06 & 0.11 & 0.17 \\
\hline $154 \mathrm{Eu}$ & 27 & 0.03 & 0.05 & 0.08 \\
\hline $155 \mathrm{Eu}$ & 24 & 0.02 & 0.05 & 0.07 \\
\hline $59 \mathrm{Fe}$ & 17 & 0.02 & 0.03 & 0.05 \\
\hline 131I & 10 & 0.02 & 0.02 & 0.03 \\
\hline $133 I$ & 11 & 0.01 & 0.02 & 0.03 \\
\hline $54 \mathrm{Mn}$ & 10 & 0.01 & 0.02 & 0.03 \\
\hline 99Mo & 69 & 0.07 & 0.14 & 0.21 \\
\hline $22 \mathrm{Na}$ & 10 & 0.01 & 0.02 & 0.03 \\
\hline $103 \mathrm{Ru}$ & 10 & 0.01 & 0.02 & 0.03 \\
\hline $106 \mathrm{Ru}$ & 85 & 0.09 & 0.17 & 0.26 \\
\hline $124 \mathrm{Sb}$ & 10 & 0.01 & 0.02 & 0.03 \\
\hline $125 \mathrm{Sb}$ & 24 & 0.02 & 0.05 & 0.07 \\
\hline $65 \mathrm{Zn}$ & 21 & 0.02 & 0.04 & 0.06 \\
\hline $95 \mathrm{ZrNb}$ & 17 & 0.02 & 0.03 & 0.05 \\
\hline
\end{tabular}

Note: The gamma nuclide library used by the analytical laboratory will contain additional radionuclides as specified by US Ecology. Naturally occurring gamma ray emitters which will be monitored and reported in the annual environmental report are not included in this listing. 
Table 7-6. Airborne radon gas measurements.

\begin{tabular}{cccc}
\hline & \multicolumn{2}{c}{ Radon in Air 1993 } & \\
\hline & $\begin{array}{c}\text { Air Sta. 1 } \\
(\mathrm{pCi} / \mathrm{L})\end{array}$ & $\begin{array}{c}\text { Air Sta. } \\
(\mathrm{pCi} / \mathrm{L})\end{array}$ & $\begin{array}{c}\text { Air Sta. 5 } \\
(\mathrm{pCi} / \mathrm{L})\end{array}$ \\
\hline May & $<1.2$ & $<1.2$ & $<1.2$ \\
Jun & $<1.0$ & $<1.0$ & $<1.0$ \\
Jul & $<0.9$ & $<0.9$ & $<0.9$ \\
Aug & $<1.1$ & $<1.1$ & $<1.1$ \\
Sep & $<0.9$ & $<0.9$ & $<0.9$ \\
Oct & $<0.9$ & $<0.9$ & $<0.9$ \\
Nov & $<1.3$ & $<1.3$ & $<1.3$ \\
Dec & 1.1 & 1.0 & $<0.9$ \\
\hline
\end{tabular}

Analysis results (alpha, beta, and tritium) for the ground water wells are presented in Table 7-7. The facility's on-site wells consist of four wells downgradient from the disposal unit (wells $3,5,8$, and 10) and an upgradient well (well 13). Ground water samples are collected quarterly. The mean concentrations of gross alpha, gross beta, and tritium from 1964 to 1986 in the off-site wells (Table 7-7) were $0.26,0.5$, and $21.4 \mathrm{~Bq} / \mathrm{L}(7.1,13.5$, and $581 \pm 725 \mathrm{pCi} / \mathrm{L})$, respectively. ${ }^{7-3}$ It should be noted that the US Ecology LLW disposal facility is located adjacent to the 200-East and 200-West facilities of the U.S. DOE Hanford Reservation (Figure 7-6). U.S. DOE's Hanford site Environmental Report for Calendar Year $1990^{7-4}$ states that tritium concentrations in the unconfined aquifer exceed 7.4 $\mathrm{E}+3 \mathrm{~Bq} / \mathrm{L}(2 \mathrm{E}+5 \mathrm{pCi} / \mathrm{L})$ in the regions surrounding the 200 -East and 200 -West areas. It is expected that tritium concentrations from these plumes could increase the levels observed in US Ecology's monitoring wells over the next several years. New wells may be required at the LLW site in order to detect the tritium plumes coming from the U.S. DOE areas. The concentrations in ground water at the U.S. DOE Hanford site regional wells (outside of the 200 Area) range from 0.15 to $11.5 \mathrm{~Bq} / \mathrm{L}$ (4 to $310 \mathrm{pCi} / \mathrm{L}$ ) for alpha, 0.6 to $19.6 \mathrm{~Bq} / \mathrm{L}(16$ to $530 \mathrm{pCi} / \mathrm{L}$ ) for beta, and 11.1 to $74.7 \mathrm{~Bq} / \mathrm{L}$ (300 to 2020 $\mathrm{pCi} / \mathrm{L}$ ) for tritium. ${ }^{7-4}$

\section{Gross Alpha and Beta Activities in Ground Water}

The gross alpha activity concentration in the on-site ground water samples varied from less than detectable to a maximum of about $0.43 \mathrm{~Bq} / \mathrm{L}(11.5 \mathrm{pCi} / \mathrm{L}$ ) (Table 7-7). The investigation level for gross alpha activity is $0.44 \mathrm{~Bq} / \mathrm{L}(12 \mathrm{pCi} / \mathrm{L})$. Gross beta activity varied from a low of $0.16 \mathrm{~Bq} / \mathrm{L}(4.2$ $\mathrm{pCi} / \mathrm{L}$ ), to a high of about $0.43 \mathrm{~Bq} / \mathrm{L}$ (11.6) (Table 7-7). The investigation level for gross beta activity is also $0.44 \mathrm{~Bq} / \mathrm{L}(12 \mathrm{pCi} / \mathrm{L})$. 
Table 7-7. Analysis results (alpha, beta, and tritium) for ground water wells. ${ }^{a}$

US Ecology On-site Wells (Figure 3)

(Operations started in 1986) $\mathrm{pCi} / \mathrm{L}$

Year

1986

1987

1988

1989

1990

1991

1992
Gross alpha ${ }^{\mathrm{a}}$

11.50

3.68

3.06

4.82

4.75

4.0

3.6
Gross beta ${ }^{\mathrm{a}}$

10.7

9.16

11.60

8.44

7.73

7.0

7.2
Tritium $^{\mathrm{a}}$

3,550

3,000

1,680

1,590

1,610

1,520

2,450

Well \#13 (upgradient well)

1992 3.6

7.2

2,450

a. Indicates the highest value for the year from all five wells.

U.S. DOE Wells (located in the vicinity of the 200 East and 200 West Area of the Hanford facility, Figure 7-4). Some of these wells are located in areas with known ground water impact by U.S. DOE operations.

$(\mathrm{pCi} / \mathrm{L})$

\begin{tabular}{lllllllll}
\hline Year & $1966-85$ & 1986 & 1987 & 1988 & 1989 & 1990 & 1991 & 1992
\end{tabular}

Gross alpha

7.1

Gross beta

13.5

Tritium

$581 \quad 3,700$

2,020

2,360

32,000

39,000

$41,100.44,100$

Values for 1966-1985 are mean concentration.

Values for 1987-1992 are the highest concentration from all off-site wells for the year.

Gross beta and alpha activity results for 1992 compare favorably with those for previous years. Results from upgradient and downgradient wells are also similar. It can be concluded from upgradient and downgradient ground water monitoring well data that site operations have not resulted in any discernable trends. 
Table 7-8. Maximum tritium concentration in ground water (on-site) wells (pCi/L).

\begin{tabular}{cccccc}
\hline Year & Well \#3 & Well \#5 & Well \#8 & Well \#10 & $\begin{array}{c}\text { (Upgradient) } \\
\text { Well \#13 }\end{array}$ \\
\hline 1986 & 3,550 & 952 & 1,180 & 884 & 1,190 \\
1987 & 3,000 & 1,140 & 1,010 & 883 & 1,120 \\
1988 & 1,680 & 690 & 690 & 690 & 1,090 \\
1989 & 1,590 & - & - & 870 & 1,490 \\
1990 & 1,610 & 1,550 & 1,140 & 952 & 1,570 \\
1991 & 1,520 & 1,570 & 997 & 928 & 1,440 \\
1992 & 2,150 & 1,740 & 1,707 & 1,270 & 2,450
\end{tabular}

a. On-site wells began operation in 1986 (Figure 3).

\section{Tritium Activity in Ground Water}

Tritium is present in ground water at the Hanford site, due to both natural processes and tritiumcontaminated liquid waste discharged to the ground from Hanford U.S. DOE facilities. Tables 7-7, 7-8, and 7-9 present maximum yearly tritium concentrations of ground water measured at US Ecology's on-site wells and U.S. DOE's wells in the vicinity of the 200-East and 200-West Areas. The investigation level for tritium in ground water well samples is $133 \mathrm{~Bq} / \mathrm{L}(3600 \mathrm{pCi} / \mathrm{L})$. No analytical results for the US Ecology on-site ground water wells exceeded investigation levels. The reporting level for tritium is $740 \mathrm{~Bq} / \mathrm{L}(20,000 \mathrm{pCi} / \mathrm{L})$ (Table $7-3)$.

Table 7-9. Maximum tritium concentrations in U.S. DOE ground water wells located in the vicinity of the 200 East and 200 West areas.

\begin{tabular}{cccc}
\hline Year & $\begin{array}{c}\text { Concentration } \\
(\mathrm{pCi} / \mathrm{L})\end{array}$ & Year & $\begin{array}{c}\text { Concentration } \\
(\mathrm{pCi} / \mathrm{L})\end{array}$ \\
\hline 1976 & 1100 & 1985 & - \\
1977 & 1600 & 1986 & 3700 \\
1978 & 3300 & 1987 & 2020 \\
1979 & 2100 & 1988 & 2360 \\
1980 & 2300 & 1989 & 32,000 \\
1981 & 2400 & 1990 & 39,400 \\
1982 & 410 & 1991 & 41,100 \\
1983 & 1600 & 1992 & 44,100 \\
1984 & 2200 & & \\
\hline
\end{tabular}




\section{Carbon-14 in Ground Water}

Analyses for carbon-14 in ground water are also provided in the US Ecology Historical and Annual Environmental Reports. ${ }^{7-3}$ All samples for 1991 and 1992 were reported as being less than the minimum detectable concentration of $7.4 \mathrm{~Bq} / \mathrm{L}(200 \mathrm{pCi} / \mathrm{L})$. The investigation level for carbon- 14 in ground water is $9.25 \mathrm{~Bq} / \mathrm{L}(250 \mathrm{pCi} / \mathrm{L})$. Analytical results do not indicate any trends in carbon- 14 concentrations.

\section{Gamma-Emitting Radionuclides in Ground Water}

Water samples from the five on-site environmental monitoring wells were analyzed by gamma spectral analysis to determine the presence of gamma-emitting radionuclides. Results of these analyses are covered extensively in the US Ecology Historical and Annual Environmental Monitoring Reports. ${ }^{7-3}$ No positive values were reported for man-made radionuclides in ground water. ${ }^{7-3}$ For 1992, Co-60, $\mathrm{Cs}-137$, and Ru-106 samples were less than the minimum detectable concentrations of $0.4 \mathrm{~Bq} / \mathrm{L}(11$ $\mathrm{pCi} / \mathrm{L}), 0.37 \mathrm{~Bq} / \mathrm{L}(10 \mathrm{pCi} / \mathrm{L})$, and $3.1 \mathrm{~Bq} / \mathrm{L}(85 \mathrm{pCi} / \mathrm{L})$, respectively. These results were seen to be consistent with historical values reported for previous years. In 1991, ground water samples, cobalt-60, cesium-137, and ruthenium-106 were reported as less than detectable. Based on comparison of 1992 analyses with results reported for previous years, no trends are apparent in the data, and it may be concluded that site operations had no effect on ground water gamma-emitting nuclide concentrations.

\section{Plutonium in Ground Water}

Ground water samples taken from site monitoring wells were analyzed for plutonium-238 and plutonium-239/240. Both plutonium-238 and plutonium-239/240 ground water concentrations have been consistently below the reporting level of $1.5 \mathrm{~Bq} / \mathrm{L}(40 \mathrm{pCi} / \mathrm{L})$, and as such, there has never been any problem associated with plutonium in ground water. The plutonium-238 and plutonium-239/240 investigation levels are $1.1 \mathrm{E}-3 \mathrm{~Bq} / \mathrm{L}(3.0 \mathrm{E}-2 \mathrm{pCi} / \mathrm{L})$.

The results reported for isotopic plutonium are consistent with historical values. Results for 1991 plutonium-238 and 239/240 were all less than $3.7 \mathrm{E}-4 \mathrm{~Bq} / \mathrm{L}(1.0 \mathrm{E}-2 \mathrm{pCi} / \mathrm{L})$.

\section{Uranium in Ground Water}

Analytical results for isotopic uranium for 1989 through 1991 are presented below in Table 7-10.

The maximum values reported in 1992 for uranium-234, uranium-235, and uranium-238 are consistent with results reported in previous years. The data indicate that only natural uranium is present.

\section{Surface Water}

Because no surface water occurs on the US Ecology site, no surface water monitoring is performed. The nearest surface water is West Lake, which is located on the U.S. DOE Hanford Site, 
approximately $6.5 \mathrm{~km}$ (4 mi) north of the US Ecology site. The U.S. DOE monitors West Lake for radioactivity.

Table 7-10. Analytical results for isotopic uranium.

\begin{tabular}{|c|c|c|c|}
\hline & \multicolumn{3}{|c|}{ (Units in $\mathrm{pCi} / \mathrm{L}$ ) } \\
\hline & U-234 & U-235 & $\mathrm{U}-238$ \\
\hline 1989 & $\begin{array}{l}1.17 \pm 0.218 \text { to } \\
2.86 \pm 0.347\end{array}$ & $\begin{array}{l}0.0044 \pm 0.0195 \text { to } \\
0.506 \pm 0.0969\end{array}$ & $\begin{array}{l}0.653 \pm 0.15 \text { to } \\
2.12 \pm 2.70\end{array}$ \\
\hline 1990 & $\begin{array}{l}1.46 \pm 1.99 \text { to } \\
2.02 \pm 0.241\end{array}$ & $\begin{array}{l}0.0182 \pm 0.0180 \text { to } \\
0.0507 \pm 0.0258\end{array}$ & $\begin{array}{l}0.804 \pm 1.29 \text { to } \\
1.41 \pm 0.180\end{array}$ \\
\hline 1991 & $\begin{array}{l}<0.1 \pm \text { to } \\
2.3 \pm 1.1 \\
\end{array}$ & $<0.1$ & $\begin{array}{l}<0.1 \text { to } \\
1.9 \pm 1.1\end{array}$ \\
\hline
\end{tabular}

\section{Air}

The environmental air monitoring program involves continuous sampling of particulates, iodine (I-125), and tritium. Air particulates and iodine are continuously sampled at the nine environmental stations located around the facility; tritium is sampled continuously at three stations. Station 1, which is located in the upwind direction and is approximately $305 \mathrm{~m}(1,000 \mathrm{ft})$ north of the current receiving area, is used as the control station for the facility. Weekly samples are collected for air particulates and I-125, while monthly composites are collected for air tritium. Analyses performed on samples include gross beta, gross alpha, I-125, tritium (in air moisture), and gamma spectroscopy. Gamma spectral analysis is performed on monthly samples of air moisture collected on silica gel columns. Sampling locations are shown in Figures 7-2, 7-3, 7-4, and 7-6.

Gross beta and gross alpha measurements of particulate air samples for the years 1978 through 1992 are presented in Table 7-11. Except for a small spike (believed to be an artifact of the small volume of air pulled through the air filter and the measurement instruments used in monitoring the particulate filters) ${ }^{7-3}$ these data do not appear to be significantly different from the normal background concentrations at locations surrounding the US Ecology LLW facility.

The 1992 annual mean concentration for I-125 at all nine stations was $3.4 \mathrm{E}-10 \mathrm{~Bq} / \mathrm{mL}(0.92 \mathrm{E}-14$ $\mu \mathrm{Ci} / \mathrm{mL})$. This concentration is approximately $0.01 \%$ of the Maximum Permissible Concentration (MPC) in unrestricted areas $(2.96 \mathrm{E}-6 \mathrm{~Bq} / \mathrm{mL}$, or $8.0 \mathrm{E}-11 \mu \mathrm{Ci} / \mathrm{mL})$, referenced in WAC 246-221-290, Appendix A, Table II, Column 1. The annual mean concentrations during 1991 varied from $1.92 \mathrm{E}-10$ to $4.0 \mathrm{E}-10 \mathrm{~Bq} / \mathrm{mL}(0.52 \mathrm{E}-14$ to $1.08 \mathrm{E}-14 \mu \mathrm{Ci} / \mathrm{mL}) .^{7-3}$ The maximum values for $\mathrm{I}-125$ for all nine stations during the years 1987 through 1992 are presented in Table 7-12.

A review of the above data shows a maximum value of $4.5 \mathrm{E}-9 \mathrm{~Bq} / \mathrm{mL}\left(12.2 \times 10^{-14} \mu \mathrm{Ci} / \mathrm{mL}\right)$ obtained for 1987 . This value is approximately $0.10 \%$ of the MPC value for unrestricted areas. 
Table 7-11. Gross beta and gross alpha measurements of particulate air samples from 1978 to 1992.

\begin{tabular}{|c|c|c|c|c|c|c|}
\hline \multirow[b]{2}{*}{ Year } & \multicolumn{3}{|c|}{$\begin{array}{c}\text { Gross Beta } \\
\left(\times 10^{-12} \mu \mathrm{Ci} / \mathrm{mL}\right)\end{array}$} & \multicolumn{3}{|c|}{$\begin{array}{c}\text { Gross alpha } \\
\left(\times 10^{-14} \mu \mathrm{Ci} / \mathrm{mL}\right)\end{array}$} \\
\hline & Lowest value & $\begin{array}{c}\text { Average } \\
\text { value }\end{array}$ & $\begin{array}{l}\text { Highest } \\
\text { value }\end{array}$ & Lowest value & $\begin{array}{l}\text { Average } \\
\text { value }\end{array}$ & $\begin{array}{l}\text { Highest } \\
\text { value }\end{array}$ \\
\hline 1978 & 0.10 & 0.50 & 1.4 & Bkgd & Bkgd & Bkgd \\
\hline 1979 & 0.02 & 0.66 & 3.7 & Bkgd & Bkgd & Bkgd \\
\hline 1980 & 0.036 & 1.1 & 210.0 & Bkgd & Bkgd & Bkgd \\
\hline 1981 & 0.022 & 1.1 & 80.0 & $\overline{\mathrm{Bkgd}}$ & Bkgd & Bkgd \\
\hline 1982 & 0.022 & 0.26 & 1.7 & Bkgd & Bkgd & Bkgd \\
\hline 1983 & 0.028 & 0.30 & 2.2 & Bkgd & Bkgd & Bkgd \\
\hline 1984 & 0.003 & 0.62 & 46.0 & 8.6 & 26 & 63 \\
\hline 1985 & 0.011 & 0.31 & 3.1 & 0.98 & 3.2 & 22 \\
\hline 1986 & 0.043 & 0.73 & 3.6 & 1.1 & 4.8 & 65 \\
\hline 1987 & 0.008 & - & 0.08 & 0.08 & - & 0.7 \\
\hline 1988 & 0.003 & - & 0.08 & 0.016 & - & 0.8 \\
\hline 1989 & 0.007 & - & 0.09 & 0.010 & - & 0.96 \\
\hline 1990 & 0.004 & - & 0.047 & 0.001 & - & 0.096 \\
\hline 1991 & - & - & 0.08 & - & - & 0.38 \\
\hline 1992 & - & - & 0.71 & - & - & 0.03 \\
\hline
\end{tabular}

Table 7-12. Maximum I-125 concentration in the air.

Maximum I-125

Concentration in Air $\left(10^{-14}\right.$

\begin{tabular}{ccc} 
Year & $10^{-9} \mathrm{~Bq} / \mathrm{mL}$ & $\mu \mathrm{Ci} / \mathrm{mL})$ \\
\hline 1987 & 4.5 & 12.20 \\
1988 & 1.16 & 3.13 \\
1989 & 3.6 & 9.77 \\
1990 & 2.0 & 5.40 \\
1991 & 2.6 & 7.0 \\
1992 & 2.18 & 5.90 \\
\hline
\end{tabular}


The results of gamma spectral analysis of the monthly composites of the weekly particulate air samples have been evaluated, and of the 108 composite samples, no man-made radionuclides were detected at concentrations above the required laboratory detection level. Naturally occurring Be-7 and $\mathrm{K}-40$ were detected in expected concentrations.

Table 7-13 lists the results of the tritium analysis for the water vapor collected in the monthly silica gel cartridges for the years 1987 through 1992. The highest value for these years (except 1991) is shown to be $3.8 \mathrm{E}-6 \mathrm{~Bq} / \mathrm{mL}(103 \mathrm{E}-12 \mu \mathrm{Ci} / \mathrm{mL})$, which represents about $0.05 \%$ of the MPC (7.4 E-3 $\mathrm{Bq} / \mathrm{mL}$, or $2.0 \mathrm{E}-7 \mu \mathrm{Ci} / \mathrm{mL}$ ) as stated in $10 \mathrm{CFR} 20$, Appendix B, Table II, Column 1 . References $7-3$ and 7-4 give values of air moisture tritium concentration for the 200 Areas (on-site) and distant communities. The upper values for these locations are $2.62 \mathrm{E}-6 \mathrm{~Bq} / \mathrm{mL}(71 \mathrm{E}-12 \mu \mathrm{Ci} / \mathrm{mL})$ and $3.3 \mathrm{E}-7$ $\mathrm{Bq} / \mathrm{mL}(9 \mathrm{E}-12 \mu \mathrm{Ci} / \mathrm{mL})$, respectively.

Table 7-13 also shows the 1991 values for the air moisture tritium concentration to be inconsistent when compared with the values obtained for other years. This discrepancy was due to a change in laboratories in August 1991. Upon reexamination and investigation, laboratory procedures were corrected. This resulted in 1992 data being more consistent with the historical data.

Table 7-13. Tritium air moisture concentrations at environmental monitoring stations 1,2 , and 5 $\left(10^{-12} \mu \mathrm{Ci} / \mathrm{mL}\right)$.

\begin{tabular}{|c|c|c|c|c|c|}
\hline \multirow[b]{2}{*}{ Year } & \multirow[b]{2}{*}{ Station 1} & \multirow[b]{2}{*}{ Station 2} & \multirow[b]{2}{*}{ Station 5} & \multicolumn{2}{|c|}{ Hanford report } \\
\hline & & & & $\begin{array}{c}\text { On site } \\
200 \text { area }\end{array}$ & $\begin{array}{c}\text { Distant } \\
\text { communities }\end{array}$ \\
\hline 1987 & 3.70 & 3.97 & 56.1 & - & - \\
\hline 1988 & 6.37 & 4.28 & 13.4 & - & - \\
\hline 1989 & 3.95 & 2.70 & 21.3 & 3.1 & 2.4 \\
\hline 1990 & 15.40 & $103.0^{3}$ & 31.3 & 71.0 & 3.4 \\
\hline 1991 & $585.0^{3}$ & $563.0^{3}$ & $633.0^{3}$ & 31.0 & 9.0 \\
\hline 1992 & 14.7 & 14.0 & 24.5 & - & - \\
\hline
\end{tabular}

Note: (1) Values given in this table are the highest values for the year.

(2) The Maximum Permissible Concentration (MPC) value for tritium for air in unrestricted areas is $2 \times$ $10^{-7} \mu \mathrm{Ci} / \mathrm{mL}$ (10 CFR 20, Appendix B, Table II, Column 1).

(3) For 1991, there is a degree of uncertainty in data reliability, due to the laboratory procedural problems which occurred during 1990. Procedure corrections were made, and the 1992 data showed consistency with historical values. Even though the tritium concentrations in air for 1991 show higher values in comparison to the historical data, the maximum monthly tritium concentration measured at Station 5 was $633.0 \mathrm{E}-12$, which is approximately 0.3 percent of the value for unrestricted area tritium concentrations in air (2E-7 $\mu \mathrm{Ci} / \mathrm{mL}$ ) listed in 10 CFR 20, Appendix B, Table II, Column 1 (also WAC 246-221-290). 
US Ecology also monitors the ventilation exhaust from the on-site package inspection facility. Samples are evaluated for gross beta, gross alpha, and I-125 concentrations. All samples were below action levels during 1992.

The averages of the measured gross beta concentrations during 1991 and 1992 were $1.63 \mathrm{E}-8$ and $1.73 \mathrm{E}-8 \mathrm{~Bq} / \mathrm{mL}(4.4 \mathrm{E}-13$ and $4.68 \mathrm{E}-13 \mu \mathrm{Ci} / \mathrm{mL})$, respectively. These are noted to be less than $0.015 \%$ of the MPC for restricted areas as given in WAC 246-22,1-290, Appendix A, Table I, Column 1.

The averages of the measured gross alpha concentrations during 1991 and 1992 were $3.48 \mathrm{E}-9$ and $2.48 \mathrm{E}-9 \mathrm{~Bq} / \mathrm{mL}(9.4 \mathrm{E}-14$ and $6.7 \mathrm{E}-14 \mu \mathrm{Ci} / \mathrm{mL})$, respectively. These values are well below the MPC for restricted areas as given in the regulations. It should be recognized, however, that air emissions from the facility only occurred during package inspection activities. Therefore, the true annual average would be well below $1 \%$ of the MPC.

For I-125, the average concentrations (conservatively calculated) during 1991 and 1992 were below $5.55 \mathrm{E}-8 \mathrm{~Bq} / \mathrm{mL}(1.5 \mathrm{E}-12 \mu \mathrm{Ci} / \mathrm{mL})$. This is much less than $1 \%$ of the MPC. ${ }^{7-3}$ Additionally, none of the nine environmental air monitoring stations exceeded the MPC for unrestricted areas.

\section{Soil}

Soil samples are collected and analyzed from Stations 1 through 9 and at the northeast and northwest corners. Analysis is performed for gross beta, total uranium, isotopic plutonium (Pu-238 and $\mathrm{Pu}-239 / 240$ ), and gamma-emitters. The results of the quarterly soil samples presented in Table 7-14 are the highest values for the year as reported in the US Ecology Historical Report and the Annual Environmental Monitoring Report.

A review of the data shows a decreasing trend in gross beta concentrations in soil, when compared with the early years. Since 1984, the gross beta concentration in soil has remained below, or very close to the reporting level of $1.3 \mathrm{~Bq} / \mathrm{g}(35 \mathrm{pCi} / \mathrm{g})($ Table $7-3)$. The values reported for gross beta activity are consistent with typical values found in the region; therefore, no contribution from the site is apparent for gross beta in the soil.

The results of the quarterly analysis for uranium activity in soil are presented in Table 7-14. The soil is analyzed for uranium on a mass basis. The mass of uranium is then converted to an activity, using the conversion factor of $2.5 \mathrm{E}-8 \mathrm{~Bq} / \mathrm{g}(6.77 \mathrm{E}-7 \mathrm{pCi} / \mathrm{g})$ from $10 \mathrm{CFR} 20$. All sample results (except 1990) for uranium were below the reporting level of $3.7 \mathrm{E}-2 \mathrm{~Bq} / \mathrm{g}(1 \mathrm{pCi} / \mathrm{g}$ ). The 1990 results show a total maximum value exceeding $3.7 \mathrm{E}-2 \mathrm{~Bq} / \mathrm{g}(1 \mathrm{pCi} / \mathrm{g})$, which may be related to the change in analytical laboratories in 1990. Total uranium and isotopic plutonium exceeded reporting levels in various samples; but upon resampling, the concentrations either fell below the reporting level or were consistent with those found throughout the region.

Gross alpha concentration in soil (Table 7-14) has varied from less than detectable to a maximum of $0.53 \mathrm{~Bq} / \mathrm{g}(14.3 \mathrm{pCi} / \mathrm{g})$. In 1987 , US Ecology ceased to analyze gross alpha concentration in soil. Since 1987, soil samples are monitored for total uranium and isotopic plutonium concentration. Gross 
Table 7-14. Soil analysis (pCi/gm). ${ }^{a}$

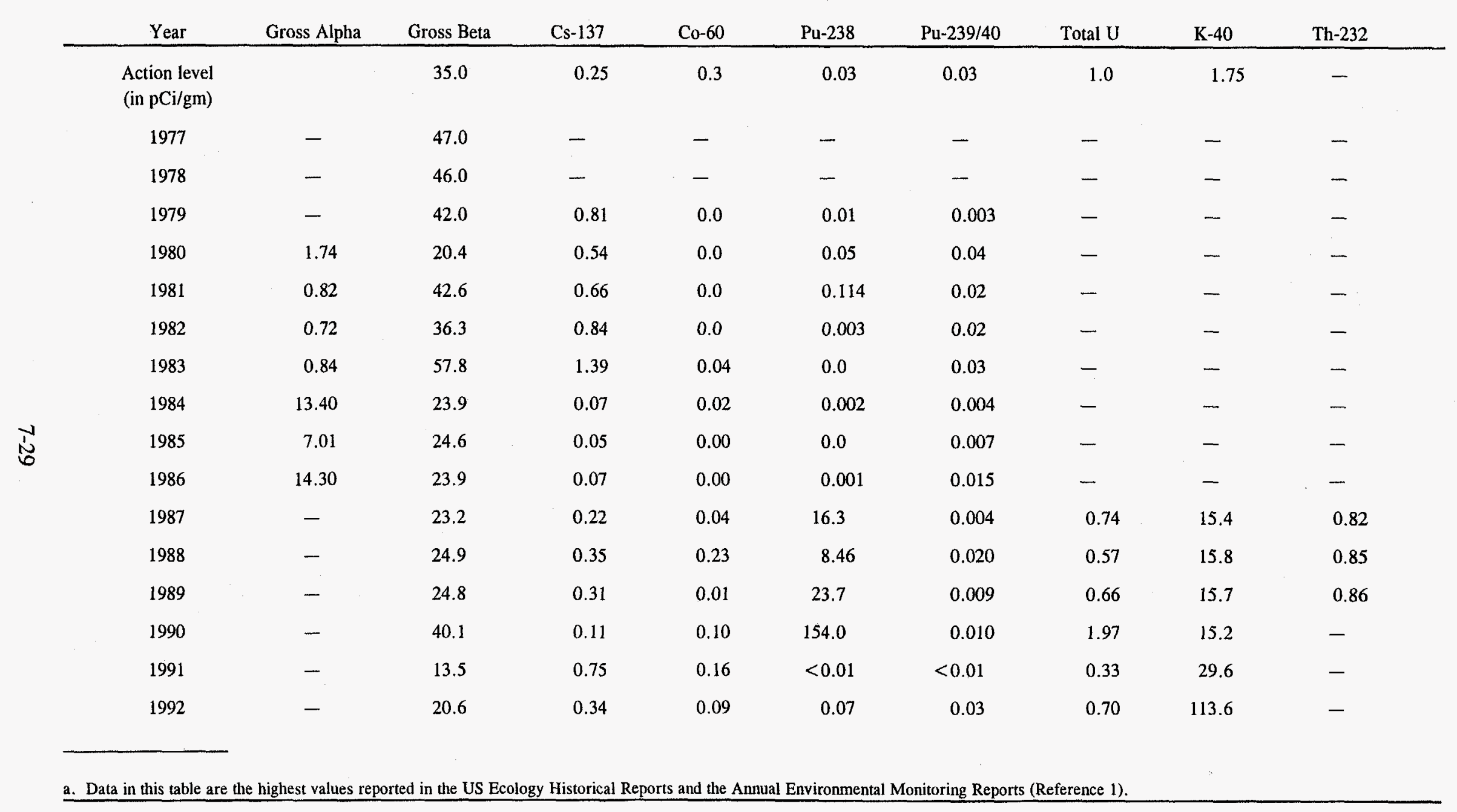


alpha concentration in soil is not monitored at the Hanford site, nor in the vicinity of the site, by U.S. DOE or its contractors.

Potassium-40 exceeded the action level of $6.5 \mathrm{E}-2 \mathrm{~Bq} / \mathrm{g}(1.75 \mathrm{pCi} / \mathrm{g})$. This is due to the current action level for $\mathrm{K}-40$, which is based on laboratory detection limits and is currently set significantly below natural background concentrations. Potassium- 40 is naturally occurring and was encountered at levels characteristic of normal background.

Cs-137 is distributed worldwide from nuclear weapons testing and the nuclear accident at Chernobyl. Concentrations of Cs-137 at the Richland LLW facility were not abnormal, considering the location of the facility within the Hanford Reservation and the historical levels found in soil in past years.

Other radionuclides which have been identified are Eu-155, Be-7, Fe-59, Zr-95, Mn-54, Ru-103, Co- $60, \mathrm{Ce}-144$, and Th-232. Based on the infrequent occurrences of positive values together with their small magnitude and the distance to population areas, radiation dose from soil pathways to the general public is very unlikely.

\section{Biota}

The protocol for the sampling and analysis of vegetation taken from the US Ecology site parallels that of the soil. Vegetation is sampled in the vicinity of the nine environmental air monitoring stations and at the northeast and northwest corners of the site on a quarterly basis whenever there is sufficient vegetation. Vegetation samples are also collected annually from the trench caps when sufficient vegetation is available. Sampling procedures require the collection of new growth whenever possible. Vegetation samples are analyzed for gross beta activity, total uranium, isotopic plutonium (Pu-238 and Pu-239/240), gamma-emitters, and tritium. The control location for vegetation monitoring, as for all sample media, is at Station 1. This station is in the upwind location and is located away from the operations area. Only deep rooted vegetation was targeted for sample collection.

Gross beta concentrations in vegetation taken at environmental monitoring stations are presented in Table 7-15, and are shown to be below the action level of $3.7 \mathrm{~Bq} / \mathrm{g}(100 \mathrm{pCi} / \mathrm{g})$. The US Ecology Historical Report ${ }^{7-3}$ for the years 1986 and before gives a range of beta activity in vegetation of $8.7 \mathrm{E}-2$ to $4.3 \mathrm{~Bq} / \mathrm{g}$ (2.36 to $117.0 \mathrm{pCi} / \mathrm{g}$ ), with a mean concentration of $0.94 \mathrm{~Bq} / \mathrm{g}(25.3 \mathrm{pCi} / \mathrm{g})$. The high for the years between 1987 through 1992 was $3.05 \mathrm{~Bq} / \mathrm{g}(82.5 \mathrm{pCi} / \mathrm{g})$. Gross beta concentration in vegetation is not monitored at the Hanford Reservation by U.S. DOE or its contractors. Typical values worldwide reported for gross beta concentration in vegetation range between 0.3 and $4.55 \mathrm{~Bq} / \mathrm{g}(8.0$ and $123.0 \mathrm{pCi} / \mathrm{g}$ ) of gross weight, and are mainly due to $\mathrm{K}-40$, lead- -210 , bismuth- 210 , and the uranium and thorium series..$^{7-3}$

Gross alpha concentration in vegetation is listed in Table $7-15$, and was below $0.37 \mathrm{~Bq} / \mathrm{g}$ $(10 \mathrm{pCi} / \mathrm{g})$. The typical concentration of gross alpha in plants worldwide is $5.0 \mathrm{E}-3$ to $0.12 \mathrm{~Bq} / \mathrm{g}$ ( 0.14 to $3.1 \mathrm{pCi} / \mathrm{g})$. There is no significant difference in the gross alpha concentration found in vegetation samples taken from the Richland LLW facility (US Ecology) and the concentration of natural alpha found in plants in the surrounding areas. 
Table 7-15. Vegetation sample analysis (pCi/gm).

\begin{tabular}{|c|c|c|c|c|c|c|c|c|c|}
\hline Year & Gross alpha & $\begin{array}{c}\text { Gross } \\
\text { beta }\end{array}$ & Ru-106 & Cs- 137 & $\mathrm{Zr}-95$ & Pu-238 & $\mathrm{Pu}-238 / 40$ & Total U & $\mathrm{Co}-60$ \\
\hline 1980 & 0.97 & 53.2 & - & 0.16 & - & 0.007 & 0.04 & - & - \\
\hline 1981 & 0.82 & 42.6 & $<0.76$ & - & $<0.04$ & 0.114 & 0.02 & - & 0.15 \\
\hline 1982 & 0.87 & 40.5 & 0.33 & - & 0.56 & 0.003 & 0.02 & - & 0.12 \\
\hline 1983 & 0.0 & 41.0 & 2.24 & 0.15 & 0.34 & 0.0 & 0.03 & - & 0.05 \\
\hline 1984 & 0.0 & 36.1 & $<0.6$ & 0.15 & $<0.1$ & 0.001 & 0.01 & - & 0.05 \\
\hline 1985 & 4.15 & 55.6 & $<0.45$ & 0.07 & 0.9 & 0.002 & 0.61 & - & 0.04 \\
\hline 1986 & 3.43 & 70.6 & $<0.3$ & 0.20 & - & 0.001 & 0.015 & - & 0.04 \\
\hline 1987 & - & 63.5 & 0.20 & 0.15 & - & - & 0.005 & 0.08 & 0.05 \\
\hline 1988 & - & 81.3 & 0.04 & 0.03 & 0.001 & 0.004 & 0.002 & 0.31 & 0.01 \\
\hline 1989 & - & 82.5 & - & 0.04 & - & 0.001 & 0.002 & 0.15 & 0.04 \\
\hline 1990 & - & 81.1 & - & - & - & - & 0.0015 & 8.8 & 2.8 \\
\hline 1991 & - & 15.6 & - & 0.08 & - & $<0.01$ & $<0.01$ & 0.18 & 0.12 \\
\hline 1992 & - & 70.1 & - & 0.03 & - & $<0.01$ & $<0.01$ & $<0.1$ & - \\
\hline
\end{tabular}

Note: (1) Data in this table are the highest values for the year reported in US Ecology's Historical Reports and Annual Environmental Monitoring Reports (Reference 1).

(2) Action levels for radionuclides in vegetation are provided in Table 7-3, "Environmental/Occupational Monitoring Requirements."

(3) The unusually high reading $(8.8 \mathrm{pCi} / \mathrm{gm})$ for total uranium for 1990 was due to laboratory procedures; since then, there has been a change of vendor. 
Total uranium concentration in vegetation is measured on a mass basis and then transformed to an activity, using the relationship of $6.77 \mathrm{E}-7 \mathrm{Ci} / \mathrm{g}$ from $10 \mathrm{CFR} 20$, Appendix B. Although the reporting level for total uranium was exceeded in 1990, the total uranium concentrations for samples taken at the US Ecology site compare favorably with regional environmental samples.

Vegetation samples from environmental monitoring stations and trench caps were analyzed for $\mathrm{Pu}-239 / 240$ and Pu-238. Yearly results of plutonium concentrations are provided in the US Ecology Historical and the Annual Environmental Monitoring Reports. ${ }^{7-3}$ Analytical results of plutonium samples on the LLW site are consistent with those obtained from the U.S. DOE Hanford Monitoring Program. Consequently, no increase in the Pu-238, Pu-239/240 concentration in vegetation is attributable to LLW facility operations.

Historical data of gamma spectral analysis for vegetation samples are provided in the US Ecology Historical and Annual Environmental Monitoring Reports. ${ }^{7-3}$ The detected radionuclides were Cs-137, $\mathrm{Pu}-239 / 240, \mathrm{Co}-60, \mathrm{Zr}-95, \mathrm{Eu}-154$, and $\mathrm{Cs}-134$. These seven radionuclides have historically accounted for about $91 \%$ of the positive indications.

From 1980-1986, the mean concentrations of Cs-137 in the vegetation samples have varied from $2.3 \mathrm{E}-3$ to $4.4 \mathrm{E}-3 \mathrm{~Bq} / \mathrm{g}(0.063 \mathrm{pCi} / \mathrm{g}$ to $0.12 \mathrm{pCi} / \mathrm{g})$. Concentrations of $\mathrm{Cs}-137$ in vegetation from Hanford on-site samples vary from less than detectable to $2.1 \mathrm{E}-2 \mathrm{~Bq} / \mathrm{g}(0.57 \mathrm{pCi} / \mathrm{g})$. Off-site concentrations varied from less than detectable to $1.0 \mathrm{E}-2 \mathrm{~Bq} / \mathrm{g}(0.27 \mathrm{pCi} / \mathrm{g}){ }^{7-3}$ These values are not significantly different from values measured at the US Ecology facility.

Although the potassium-40 levels were greater than the action levels, the results reported are consistent with natural background levels of the region.

Iodine-131, cerium-141, and barium/lanthanum-140 were positively identified, but the values were within the range of historical data.

Selected annual trench cap samples of vegetation have been analyzed for tritium for trending purposes. Tritium results from this program have varied from less than detectable to greater than 1.5 $\mathrm{E}+5 \mathrm{~Bq} / \mathrm{L}(4 \mathrm{E}+6 \mathrm{pCi} / \mathrm{L}$ ) during 1988-1992. Because of this variability, alternative methods are being investigated for performing tritium vegetation analysis.

\section{Direct Radiation}

Direct radiation monitoring was conducted using thermoluminescent dosimeters (TLDs) that surround the facility. TLDs are changed monthly at locations on the north, south, east, and west fence lines and at fence line positions nearest each active disposal trench. Quarterly dosimeters are placed at the north, south, east, and west fence lines (the same as for monthly) and at the northeast, northwest, southeast, and southwest corners of the facility. Two control dosimeters (one monthly, one quarterly) are located at environmental air monitoring Station 1. 
Table 7-16. Ambient gamma (penetrating radiation) (mrem/yr).

\begin{tabular}{lr}
\hline Year & mrem/yr \\
\hline 1978 & 106.0 \\
1979 & 103.0 \\
1980 & 87.0 \\
1981 & 113.5 \\
1982 & 94.5 \\
1983 & 93.6 \\
1984 & 94.0 \\
1985 & \\
1986 & 178.6 \\
1987 & 172.0 \\
1988 & 175.0 \\
1989 & 118.0 \\
1990 & 130.0 \\
1991 & 161.0 \\
1992 & 172.0 \\
& 174.0
\end{tabular}

Note: (1) The above data indicate the highest annual ambient gamma values from all sample stations at the Richland (US Ecology) LLW facility, as reported in the Annual Environmental Reports, DOH, State of Washington (Reference 8).

(2) The action level for direct gamma radiation is $500 \mathrm{mrem} / \mathrm{yr}$, and is providęd in Table 3, "Environmental/Occupational Monitoring Requirements."

TLD data (1978-1992) for the Richland LLW facility are provided in Table 7-16 and shown in Figure 7-7. These data are the highest ambient gamma values for each year obtained from TLDs located around the facility perimeter. A review of these data indicates that the annual readings remained well below the regulatory limit of 5.0 E-3 sievert/y (500 mrem/year) during the years of operation of the LLW facility. The highest value $(1.78 \mathrm{E}-3$ sievert/y for 1985 , or $178 \mathrm{mrem})$ is only about $35 \%$ of the applicable regulatory limit at that time.

\section{NON-RADIOLOGICAL ENVIRONMENTAL PROGRAM}

The non-radiological environmental monitoring program consists of ground water monitoring at the five wells (the same as those used also for radiological monitoring), and the experimental vadose zone soil gas monitoring program. 


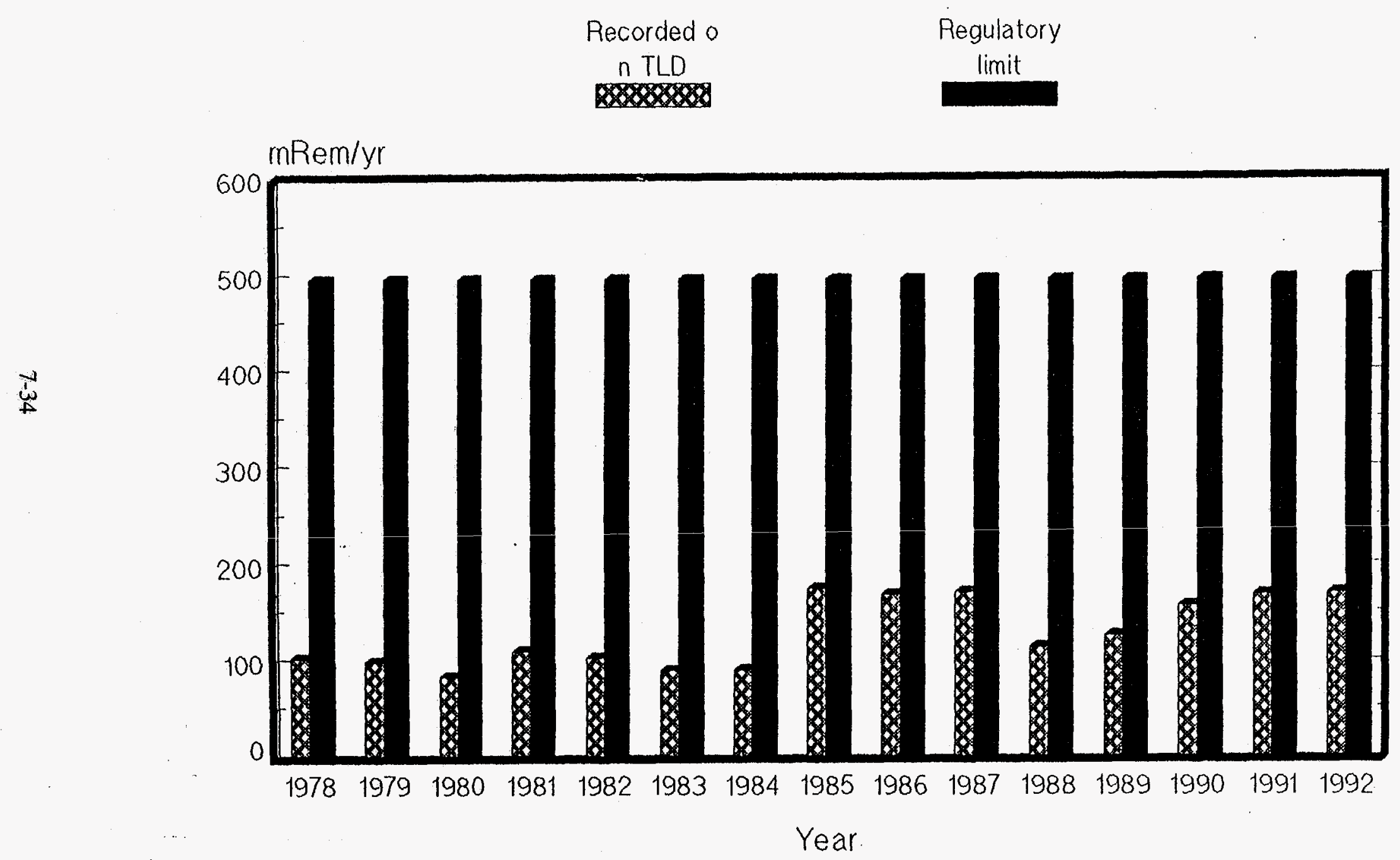

Figure 7-7. Ambient gamma (mrem/yr). 


\section{Non-Radiological Ground Water Analysis}

Ground water monitoring for non-radiological constituents is performed quarterly. The procedure for gathering these samples is the same as that for radiological samples, with the exception that non-radiological samples are placed in an ice chest and maintained at $4^{\circ} \mathrm{C}\left(39^{\circ} \mathrm{F}\right)$. On-site ground water samples are analyzed for specific conductivity, total organic carbon, nitrates, and total dissolved solids. A review of the results of these analyses (Table 7-17) shows that specific conductivity of the ground water samples (1992) varied from $300 \mathrm{umho} / \mathrm{cm}$ to $439 \mathrm{umho} / \mathrm{cm}$. These data, when compared with previous years, show that the trend has not changed appreciably since analysis began in 1986 . Likewise, results for total organic carbon (TOC), nitrates, and total dissolved solids (TDS) were consistent with the values received for previous years..$^{7-3}$

\section{Vadose Zone Monitoring Program}

In November 1991, US Ecology installed three wells into the unsaturated soil zone as part of a two-year research project required by the Washington State Department of Health. Well VW-101 was installed between Trenches 4 and 5 at the east end of the site. Well VW-102 was installed between Trenchs 10 and $11 \mathrm{~A}$, also on the east end. A background well VW-100 was installed away from current disposal areas in the northwest corner of the site.

Organic vapors of xylene, toluene, and methane/combustible gases are included in the vadose zone monitoring testing program.

\section{SUMMARY}

The Richland facility performs environmental monitoring to demonstrate compliance with federal, state, and local regulations; confirm adherence to environmental protection policies; and support environmental management decisions.

Due to the location of the facility within the Hanford Reservation, there is an extremely low probability of any effluents reaching the general population. Analysis of vegetation samples serves to provide an indication of any radionuclides which could be included in the diet of wildlife:

The Washington State Department of Health conducts an independent environmental radiation monitoring program at the Richland (US Ecology) facility. This program conducts extensive data evaluation and selective monitoring to ensure the adequacy and accuracy of the licensee's program.

The results from past environmental monitoring demonstrate that disposal operations have not resulted in measurable increases on a long-term basis in the concentration of radioactivity in air, soil, vegetation, or ground water in the vicinity of the facility. However, some of the media have exhibited apparent short-term increases from time to time. Due to the location of the facility within the Hanford Reservation, the origin of the radioactivity is not easily determined. With this in mind, the siting of environmental monitoring points at locations surrounding the disposal facility has assisted in providing environmental data that can be used to determine the radiological impact from the disposal facility. 
Table 7-17. Chemical analysis of on-site well samples-1992.

TOC $(\mathrm{ppb})$

\begin{tabular}{|c|c|c|c|c|c|c|c|c|c|}
\hline $\begin{array}{c}\text { Well } \\
\text { number }\end{array}$ & Qtr. & Temp ${ }^{\circ} \mathrm{C}$ & $\begin{array}{c}\text { Specific } \\
\text { conductivity } \\
\text { (umho/cm) }\end{array}$ & P1 & $\mathrm{P} 2$ & $\mathrm{P} 2$ & $\mathrm{P} 4$ & $\begin{array}{c}\text { Nitrates } \\
(\mathrm{ppm})\end{array}$ & $\begin{array}{c}\text { TDS } \\
(\mathrm{ppm})\end{array}$ \\
\hline \multirow[t]{4}{*}{3} & 1 & 19.4 & 424 & B & B & B & B & 4.6 & 277 \\
\hline & 2 & 21.2 & 310 & B & B & B & B & 4.6 & 258 \\
\hline & 3 & 22.5 & 360 & B & B & B & B & 5.8 & 235 \\
\hline & 4 & 19.7 & 439 & B & B & B & B & 4.4 & 219 \\
\hline \multirow[t]{4}{*}{5} & 1 & 18.6 & 392 & B & B & B & B & 4.6 & 269 \\
\hline & 2 & 20.0 & 300 & 1200 & 1200 & $B$ & B & 4.3 & 258 \\
\hline & 3 & 22.3 & 360 & B & B & B & B & 4.7 & 224 \\
\hline & 4 & 18.8 & 435 & B & B & $\mathrm{B}$ & B & 4.3 & 123 \\
\hline \multirow[t]{4}{*}{8} & 1 & 19.4 & 388 & B & B & $\mathrm{B}$ & B & 4.1 & 275 \\
\hline & 2 & 21.1 & 300 & B & B & 1600 & B & 4.2 & 255 \\
\hline & 3 & 23.1 & 360 & 1300 & 1700 & 1200 & 1200 & 5.1 & 232 \\
\hline & 4 & 18.0 & 430 & B & B & B & B & 4.3 & 216 \\
\hline \multirow[t]{4}{*}{10} & 1 & 18.0 & 403 & B & $\mathbf{B}$ & $\mathrm{B}$ & B & 4.3 & 278 \\
\hline & 2 & 21.5 & 300 & B & 3400 & B & 1900 & 4.0 & 270 \\
\hline & 3 & 21.4 & 350 & B & B & B & B & 2.0 & 209 \\
\hline & 4 & 18.7 & 428 & B & B & B & B & 3.7 & 224 \\
\hline \multirow[t]{4}{*}{$13^{\mathrm{c}}$} & 1 & 19.3 & 397 & B & B & B & B & 3.7 & 287 \\
\hline & 2 & 20.8 & 300 & B & B & B & 1300 & 4.9 & 266 \\
\hline & 3 & 21.7 & 350 & B & $\mathbf{B}$ & $\mathrm{B}$ & B & 4.5 & 202 \\
\hline & 4 & 19.5 & 429 & $\mathbf{B}$ & B & B & B & 4.4 & 228 \\
\hline \multicolumn{10}{|c|}{ B - TOC results reported as less than $1000 \mathrm{ppb}$ minimum detectable concentration. } \\
\hline $\mathrm{U}$ & we & & & & & & & & \\
\hline
\end{tabular}


The environmental monitoring data are summarized below:

- The gross alpha and gross beta results for air are consistent with background concentrations reported in previous years, and no trends were found which would indicate a contribution from the site.

- The results of gamma spectral analysis of the monthly composites of the weekly particulate air samples showed that no man-made radionuclides were detected. Naturally-occurring $\mathrm{Be}-7$ and $\mathrm{K}-40$ were detected in expected concentrations. The US Ecology air sampling program ${ }^{7-3}$ found no man-made nuclides (e.g., Pu-238 and Pu-239/240, Cs-137, Fe-59, $\mathrm{Mn}-54, \mathrm{Eu}-155, \mathrm{Ba} / \mathrm{La}-140, \mathrm{Zr} / \mathrm{Nb}-95$, Ru-103, Co-60, Ce-141, and Ce-144).

- The tritium in air moisture collected at the US Ecology facility is consistent with the results obtained from surrounding areas and facilities.

- All samples taken from the ventilation exhaust system at the package inspection facility is evaluated for gross beta, gross alpha, and I-125 concentrations. All samples were below action levels during 1992, and none of the nine environmental air monitoring stations exceeded the maximum permissible concentration for unrestricted areas.

Vegetation is sampled in the vicinity of the nine environmental air monitoring stations and at the northeast and northwest corners of the site on a quarterly basis whenever there is sufficient vegetation. Vegetation samples are also collected annually from the trench caps when sufficient vegetation is available. Sampling procedures require the collection of new growth whenever possible. Vegetation samples are analyzed for gross beta activity, total uranium, isotopic plutonium (Pu-238 and $\mathrm{Pu}-239 / 240$ ), gamma-emitters, and tritium. Concentrations of radionuclides measured in vegetation were below DOH action levels (Table 7-3).

Direct radiation monitoring is performed using thermoluminescent dosimeters (TLDs) which surround the facility. Results of TLD surveys are given in Table 7-16 and Figure 7-7. The highest direct radiation value recorded was approximately 35 percent of the applicable regulatory limit.

Ground water samples are collected quarterly from US Ecology's on-site wells $(3,5,8,10$, and 13). Ground water samples are analyzed for radiological as well as non-radiological constituents. Radiological analyses include gross alpha, gross beta, tritium, C-14, gamma-emitters, isotopic plutonium (Pu-238 and Pu-239/240), and isotopic uranium (U-234, U-235, and U-238). Nonradiological parameters include temperature, specific conductivity, total organic carbon (TOC), nitrates, and total dissolved solids (TDS).

Gross alpha and gross beta concentrations for the on-site ground water wells (Table 7-7) have been at normal background concentrations. Since their operation in 1986, the concentrations of gross alpha and beta have remained below the action levels (Table 7-3). Tritium in ground water is present, due to past operations by the Department of Energy. Tritium concentrations (Table 7-7) for US Ecology's on-site wells have been below the investigation level of $133.0 \mathrm{~Bq} / \mathrm{L}(3600 \mathrm{pCi} / \mathrm{L})$. 
Carbon-14 in ground water was reported below the minimum detectable concentration of $7.4 \mathrm{~Bq} / \mathrm{L}(200 \mathrm{pCi} / \mathrm{L})$ throughout 1992 , as well as for previous years.

Gamma spectral analysis of ground water samples did not reveal the presence of any man-made gamma-emitters above the action levels. Isotopic plutonium concentrations for various samples reported positive results, but all were less than the investigation level.

Isotopic uranium occurred at normally expected concentrations (natural background) throughout 1992 , and is consistent with the data for previous years.

The results from the environmental monitoring of radiological and non-radiological analysis demonstrate that disposal operations have not resulted in any measurable increases in the concentration of radioactivity in air, soil, vegetation, or ground water in the vicinity of the facility, and that the 25 mrem annual dose limit has not been exceeded. 


\section{REFERENCES}

7-1. State of Washington Radioactive Materials License (WN-1019-2), Amendment No. 18, 1992, issued by the State of Washington to US Ecology, Inc., Olympia, Washington.

7-2. Hanford Site Environmental Report for 1991, Pacific Northwest Laboratory, Richland, Washington.

7-3. US Ecology Richland Facility Standards Manual, US Ecology, Inc., Richland, Washington.

7-4. US Ecology's Historical Environmental Monitoring Report (1966-1986) and Annual Environmental Monitoring Reports (1987-1992) for US Ecology's Low-Level Radioactive Waste Disposal Facility, US Ecology, Inc., Richland, Washington. 


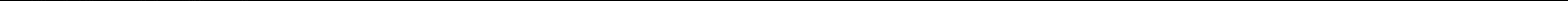

